\title{
Turismo e território no Brasil e na Itália novas perspectivas, novos desafios
}

\author{
Glaucio José Marafon \\ Marcelo Antonio Sotratti \\ Marina Faccioli \\ (orgs.)
}

MARAFON, GJ., SOTRATTI, MA., and FACCIOLI, M., comps. Turismo e território no Brasil e na Itália: novas perspectivas, novos desafios [online]. Rio de Janeiro: EdUERJ, 2014, 299 p. ISBN 978-85-7511445-2. https://doi.org/10.7476/9788575114452.

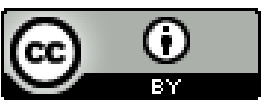

All the contents of this work, except where otherwise noted, is licensed under a Creative Commons Attribution 4.0 International license.

Todo o conteúdo deste trabalho, exceto quando houver ressalva, é publicado sob a licença Creative Commons Atribição 4.0.

Todo el contenido de esta obra, excepto donde se indique lo contrario, está bajo licencia de la licencia $\underline{\text { Creative }}$ Commons Reconocimento 4.0. 
Turismo e território no Brasil e na Itália: novas perspectivas, novos desafios 


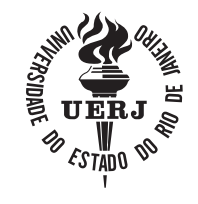

UNIVERSIDADE DO ESTADO DO RIO DE JANEIRO

\author{
Reitor \\ Ricardo Vieiralves de Castro
}

Vice-reitor

Paulo Roberto Volpato Dias

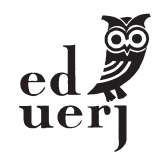

EDITORA DA UNIVERSIDADE DO

ESTADO DO RIO DE JANEIRO

\title{
Conselho Editorial
}

Antonio Augusto Passos Videira

Erick Felinto de Oliveira

Flora Süssekind

Italo Moriconi (presidente)

Ivo Barbieri

Lucia Maria Bastos Pereira das Neves 


\title{
Turismo e território no Brasil e na Itália: novas perspectivas, novos desafios
}

\author{
organização \\ Glaucio José Marafon \\ Marcelo Antonio Sotratti \\ Marina Faccioli
}

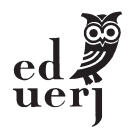

Rio de Janeiro 2014 
Copyright (C) 2014, dos autores.

Todos os direitos desta edição reservados à Editora da Universidade do Estado do Rio de Janeiro. É proibida a duplicação ou reprodução deste volume, ou de parte do mesmo, em quaisquer meios, sem autorização expressa da editora.

\section{EdUERJ}

Editora da UNIVERSIDADE DO ESTADO DO RIO DE JANEIRO

Rua São Francisco Xavier, 524 - Maracanã

CEP 20550-013 - Rio de Janeiro - RJ

Tel./Fax: (21) 2334-0720 / 2334-0721

www.eduerj.uerj.br

eduerj@uerj.br

$\begin{array}{ll}\text { Editor Executivo } & \text { Italo Moriconi } \\ \text { Coordenadora Administrativa } & \text { Elisete Cantuária } \\ \text { Apoio Administrativo } & \text { Roberto Levi } \\ \text { Coordenadora Editorial } & \text { Silvia Nóbrega } \\ \text { Assistente Editorial } & \text { Thiago Braz } \\ \text { Coordenadora de Produção } & \text { Rosania Rolins } \\ \text { Assistente de Produção } & \text { Mauro Siqueira } \\ \text { Revisão } & \text { Andréa Ribeiro } \\ & \text { Juliana Travassos } \\ \text { Capa } & \text { Heloisa Fortes } \\ \text { Diagramação } & \text { Emilio Biscardi }\end{array}$

T938 Turismo e território no Brasil e na Itália: novas perspectivas, novos desafios / organização Glaucio José Marafon, Marcelo Antonio Sotratti, Marina Faccioli. - Rio de Janeiro: EdUERJ, 2014. $300 \mathrm{p}$.

ISBN 978-85-7511-355-4

1. Brasil - Descrições e viagens. 2. Itália - Descrições e viagens. 3. Turismo cultural - Brasil. 4. Turismo cultural - Itália. I. Marafon, Gláucio José. II. Sotratti, Marcelo Antonio. III. Faccioli, Marina.

CDU 910.4(81)

Imagem de capa: Rio de Janeiro pela Vista Chinesa, Emilio Biscardi. 


\section{Sumário}

Prefácio - "Navegar é preciso", viajar de forma inteligente também: apontamentos para um possível roteiro cultural ítalo-brasileiro 7 Aniello Angelo Avella

Apresentação

Glaucio José Marafon, Marcelo Antonio Sotratti e Marina Faccioli

Parte 1 - Novos olhares do turismo no território brasileiro .21

Turismo cultural e patrimônio cultural: aproximaçōes e contrastes.

Marcelo Antonio Sotratti

A inserção da variável ambiental no planejamento

turístico: por uma abordagem estratégica 41

Clara Carvalho de Lemos

Turismo solidário: em busca de um conceito 67 Rafael Angelo Fortunato

Turismo e saúde: discussão de uma política de saúde do viajante no Brasil

Vanina Heidy Matos Silva e Christovam Barcellos 
História e cultura urbana carioca: a natureza turística do Rio de Janeiro entre a cidade das letras e a cidade maravilhosa Amanda Danelli Costa

Parte 2 - Turismo e desenvolvimento territorial na Itália 163

Problematiche territoriali del turismo a Roma:

due casi di studio

Marina Faccioli

Il Lago di Como: i molti turismi di un territorio turistico.

Paola Nicoletta Imbesi

Un nuovo modo di pianificare il processo di sviluppo turistico

Francesca Spagnuolo

La declinazione della sostenibilità al turismo Anna Tanzarella

Come spremere acqua dalle pietre: un progetto a $360^{\circ}$. Il caso dell'Orto dei Tu'rat come fattore ambientale e turistico 273 Alessandro Macchia

Sobre os autores 297 


\section{Prefácio \\ "Navegar é preciso", viajar de forma inteligente também: apontamentos para um possivel roteiro cultural ítalo-brasileiro}

Aniello Angelo Avella

Navegadores antigos tinham uma frase gloriosa: 'Navegar é preciso; viver não é preciso'. Quero para mim o espirito desta frase...

Fernando Pessoa

Fenômeno de grande atualidade, o chamado "turismo cultural" (expressão problemática pela dificuldade de definir e conciliar os termos turismo e cultura) merece ser estudado em seus diversos aspectos. Entre eles, são de especial relevância os motivos históricos ligados à tradição da viagem cultural e suas implicações socioeconômicas, que revelam os mecanismos por meio dos quais se torna possível usufruir da cultura como elemento de lazer. Ao mesmo tempo, é preciso levar em consideração a característica peculiar da viagem, fonte primária do "novo", pois ela cria relaçôes sociais entre pessoas e povos diferentes, situaçôes de sociabilidade 
que produzem transformações das identidades sociais. Quando uma pessoa ou um povo entra em contato com outros grupos étnicos, é obrigado a pôr em discussão alguns aspectos do seu próprio estilo de vida para definir uma imagem de si que o torne distinguível e compreensível aos olhos dos "outros" (Leed, 1991).

Deixando de lado as dificuldades teóricas e conceituais de uma definição de "turismo cultural", parece evidente a importância da conservação e preservação do patrimônio artístico, seja como memória de acontecimentos e tradições, seja como fator de atração do viajante, com significativas implicações no campo econômico. A Itália, com a extraordinária riqueza do seu acervo monumental, sempre foi e continua sendo uma das principais metas do turismo mundial; as comemorações dos 150 anos da unificação (1861-2011), momento de profundas reflexões sobre o processo de formação da identidade nacional, ensejaram a revisitação do papel da paisagem e dos monumentos na construção da imagem do país. Ao mesmo tempo, os problemas derivados da exploração incontrolada do território e das alterações do sistema hidrogeológico se tornaram assuntos cada vez mais urgentes no debate político e institucional.

O Brasil, por sua vez, oferece aos visitantes os encantos da sua natureza, a variedade das paisagens, a enorme biodiversidade e pluralidade de tradições. Também em vista dos grandes eventos esportivos dos próximos anos, é importante repensar criticamente estratégias de desenvolvimento territorial, educacional e cultural, e implementar as sinergias entre os múltiplos atores envolvidos.

No panorama de ofertas, o visitador "inteligente" poderá encontrar uma "jazida artística" ítalo-brasileira ainda quase inexplorada. Trata-se da coleção que D. Pedro doou ao Brasil logo depois da morte da sua esposa, a napolitana Teresa Cristina de Bourbon, querendo que levasse o nome dela. A coleção é formada por cerca de 20 mil itens, incluindo incunábulos, livros raros, fotografias de época, quadros de grandes autores italianos - como 
Tiziano, Tintoretto, Annibale Carracci e Salvator Rosa -, gravuras de Piranesi e de outros artistas e objetos de arte. A Coleção Teresa Cristina encontra-se em boa parte localizada no Rio de Janeiro: na Biblioteca Nacional, no Museu Histórico Nacional e no Instituto Histórico e Geográfico Brasileiro (IHGB). Este possui também farta documentação referente às relações da imperatriz com sua família em Nápoles.

Também de enorme importância é o acervo de arte pompeiana e etrusca que hoje se encontra no Brasil graças à imperatriz napolitana. Educada no clima de grande interesse pela arqueologia despertado pelas escavações realizadas nas cidades de Herculano e Pompéia, Teresa Cristina conhecia muito bem as ricas coleções do Museo Borbonico de Nápoles. Na bagagem que trouxe com ela no navio aportado em 1843 no Rio de Janeiro, estavam numerosas caixas repletas de peças antigas.

Estando no Brasil, ela promoveu escavações numa área da sua propriedade em Veio, ao norte de Roma, uma pequena cidade que primeiro foi etrusca e, depois, integrada ao domínio romano. Para dirigir essas escavações, Dona Teresa Cristina convidou os dois célebres arqueólogos italianos, Canina e Lanciani. Entre as obras mais representativas está a magnífica escultura representando Antínoo, que foi doada em 1880 pela imperatriz à Academia de Belas Artes do Rio de Janeiro. A estátua encontra-se hoje no Museu Nacional de Belas Artes. Até a proclamação da República em 1889, quando foi obrigada a partir para o exílio ao lado de D. Pedro, a imperatriz continuou a enriquecer sua coleção, composta por mais de setecentas peças, em boa parte expostas nas salas da Quinta da Boa Vista.

A partir de tais considerações, não é difícil evidenciar aspectos, momentos e figuras proeminentes do processo de aproximação entre Itália e Brasil, por meio dos relatos de personalidades capazes de realizar uma "viagem inteligente", conforme o título de uma coletânea que reúne os textos de sete famosos escritores. 
Entre eles, está "Um passeio pelo eterno", de Antonio Callado, o relato de uma espécie de moderno Grand Tour pela Itália, realizado pelo escritor em 1991 (Emedato, 2004).

Do ponto de vista histórico, há de se tomar como ponto de partida a metade do século XIX, quando o Brasil estava começando a definir os traços fundamentais das suas estruturas políticas, sociais e culturais, enquanto a Itália vinha completando o seu "Risorgimento", para se tornar nação (Lupo, 2011).

As migrações do final do século, que produziram o deslocamento de grandes contingentes da população italiana para as Américas, lançaram no Brasil as raízes da comunidade de "oriundi”, que, com cerca de 35 milhões de indivíduos, hoje constitui a maior colônia de origem italiana no mundo.

A imigração italiana no Brasil, impulsionada pelos problemas econômicos e sociais da nação recém-unificada, foi favorecida por fatores ligados às heranças culturais comuns, cuja expressão maior foi a imperatriz Teresa Cristina de Bourbon. A sua biografia, recentemente publicada, visa resgatar uma personalidade injustamente pouco e mal considerada pela historiografia (Avella, 2011). Na realidade, a sua ação foi elemento dinamizador de eventos de grande vulto. O Rio de Janeiro tornou-se, graças às iniciativas de Teresa Cristina, o ponto de partida e chegada de inúmeras travessias entre os dois lados do oceano, nos campos da música, da literatura, do teatro, das artes plásticas, com evidentes implicações políticas e sociais. Desta forma, toma uma nova configuração, em termos histórico-culturais, a atuação dos numerosos italianos que animaram a cena carioca no final do século XIX e início de XX, dos quais se deve reconhecer o contributo extraordinário na modernização da cidade. Oriundos em boa parte do Sul da Itália, terra de origem de Teresa Cristina, eles se assinalaram em todos os setores da vida social. Ao lado de empresários que fizeram sucesso e dinheiro, como os irmãos Antonio e Giuseppe Jannuzzi, estavam os "scalpellini", chegados da pequena cidade de 
Fuscaldo, na Calábria, assim como os trabalhadores da citricultura e da produção de carvão que atuaram na atual Baixada Fluminense, os operários do complexo têxtil da Gávea Fabril, onde uma rua era chamada "Baixa Itália", e ainda os jornaleiros "calabrisi", que se tornaram donos de praticamente todas as bancas da cidade (Schiavo Weyrauch, 2009).

Com base neste panorama histórico, pode-se dizer que o Segundo Império foi um "momento decisivo" - usando uma famosa expressão de Antonio Candido - na construção do sistema de relaçôes políticas, sociais e culturais entre Brasil e Itália; foi o período em que as numerosas e esparsas influências italianas deixaram de ser episódicas para se tornarem sistêmicas. A partir daí, a visão da Itália como pátria da arte, da criatividade, do engenho e do bom gosto começou a tomar uma dimensão cada vez mais ampla no imaginário coletivo dos brasileiros. Já no século XX, artistas como Eliseu D'Angelo Visconti, nascido numa pequena aldeia da região de Nápoles, Victor Brecheret, Anita Malfatti, José Pancetti, Cândido Portinari e tantos outros deram vida aos melhores resultados da "deglutição" da herança italiana em suas obras.

Entre os que sabiam viajar de maneira "inteligente" à época do Segundo Império, Nísia Floresta ocupa um lugar de especial destaque. Nascida no interior do Rio Grande do Norte, em 1810, com o nome de Dionísia Gonçalves Pinto, ela residiu também em Pernambuco, Rio Grande do Sul e Rio de Janeiro antes de se mudar para a Europa, em 1849. Ela residiu em Portugal, Inglaterra, Itália, França, viajou frequentemente pelos países do velho mundo e faleceu em 1885 em Rouen, no interior da França.

Nísia Floresta, como se sabe, foi pioneira em várias frentes; por exemplo, foi uma das primeiras a defender os direitos das mulheres. Em 1859, em Florença, ela publica Scintille d' un' anima brasiliana, que reúne cinco ensaios: "Il Brasile", "Labisso sotto i fiori della civilità", "La donna", "Viaggio magnetico" e "Una passeggiata al giardino di Lussemburgo". Durante este ano e nos 
dois seguintes, a autora viaja pela Itália e a Grécia, residindo em diversas cidades.

Em 1864, em Paris, foi publicado o primeiro volume de Trois ans en Italie, suivis d'un voyage en Grèce. Nesse livro, Floresta debate os problemas políticos e sociais italianos e reflete sobre a história e as manifestaçôes culturais locais. Ao mesmo tempo, ela condena com força a escravidão no Brasil. Esse "diário de viagem" constitui um valioso documento para o estudo da história italiana, principalmente porque a autora relata, em suas páginas, os acontecimentos observados pela perspectiva dos dominados. Trois ans en Italie compõe um "afresco" da vida social e política italiana da época, tornando-se fonte de pesquisa para estudos de natureza científica, referentes à história, antropologia, sociologia, literatura, arte.

A lista de autores brasileiros descrevendo a Itália e "construindo" a sua imagem é extensa. Carlos Magalhães de Azeredo, o mais novo dos fundadores da Academia Brasileira de Letras, morou durante muitos anos na capital italiana a partir de 1896 . Em suas Memórias, ele escreve páginas cheias de carinho pela "divina Roma" (Azeredo, 2003).

Em seus Poemas italianos, compostos durante uma viagem em 1953, Cecília Meireles contempla as antiguidades de "Roma dos altos sonhos e das largas ruínas", bebe as águas mitológicas de suas fontes, observa carinhosamente características e costumes dos seus habitantes, encanta-se com as belezas de Florença, Siena, Pisa, Pistoia, Veneza, Milão, Nápoles, Sorrento. Na criação literária de Cecília, passado, presente, história, lenda e mito cruzam-se num mosaico marcado pela vivacidade das cores. A poetisa viaja pela Itália e escreve com a atitude de quem está regressando às suas raízes mais profundas, para usar a metáfora fitomórfica tão cara a Sérgio Buarque de Holanda.

Roma seria o princípio de tudo aos olhos de Cecília e, em geral, dos intelectuais brasileiros que visitam a Itália. A empatia 
ente as duas culturas é tamanha que Darcy Ribeiro chega a dizer: "A nova Roma está aqui. Encarnada em lusitanidade, Roma nas Américas vestiu-se de carne índia e de carne negra para construir esta enorme latinidade" (Ribeiro, 1987).

Sérgio Buarque de Holanda, professor na Universidade de Roma entre 1952 e 1954, e depois seu filho Chico, exilado na capital italiana em 1969, Murilo Mendes, Haroldo de Campos, Antonio Callado, Silviano Santiago e numerosos outros, ao visitar a Itália, ficam marcados pela paixão e declaram o seu Amor a Roma, conforme o título palindrômico de um livro de Afonso Arinos de Melo Franco (1982).

Num imaginário mapa-múndi sentimental da cultura brasileira, Roma e Itália ocupam sem dúvida um lugar privilegiado. Os italianos em geral, por sua vez, ainda consideram o Brasil em especial pelo lado exótico e pela cordialidade com a qual se sentem acolhidos. É chegada a hora de modificar estereótipos e lugares comuns, abrindo espaços para uma ou mais formas de "viagem inteligente".

\section{Referências}

AZEREDO, Carlos Magalhães de. Memórias. Rio de Janeiro: Academia Brasileira de Letras, 2003.

EMEDATO, Luiz Fernando (org.). Viagem inteligente. São Paulo: Geração Editorial, 2004.

LEED, Eric. J. The mind of the travelers. From Gilgamesh to global tourism. Nova York: Basic Books, 1991.

LUPO, Salvatore. Lunificazione italiana. Roma: Donzelli, 2011.

RIBEIRO, Darcy. "Siamo noi i neo-romani”. L'Illustrazione Italiana, Milão, jul. 1987, n. 44, a. CXV.

SCHIAVO WEYRAUCH, Cléia. Deus abençoe esta bagunça. Imigrantes italianos na cidade do Rio de Janeiro. Rio de Janeiro: Comunità, 2009. 


\section{Apresentação}

Glaucio José Marafon

Marcelo Antonio Sotratti

Marina Faccioli

Este livro resulta de um trabalho de cooperação entre o Instituto de Geografia da Universidade do Estado do Rio de Janeiro (UERJ) e o Departamento de Turismo da Universidade Tor Vergata (Roma Dois), objetivando a troca de experiências entre os centros de pesquisas em turismo nos dois países. São apresentados cinco textos de pesquisadores brasileiros e cinco de pesquisadores italianos que certamente contribuem para o debate sobre os temas turismo e território, brindando-nos com novas abordagens no Brasil e na Itália. Como resultado, além deste livro, tivemos a vinda da professora Marina Faccioli ao Brasil, que atuou como professora visitante no Instituto de Geografia da UERJ, além da realização de uma mostra sobre Stradelli e seus retratos sobre a Amazônia.

Na primeira parte do livro, "Novos olhares do turismo no território brasileiro", consta o artigo do professor Marcelo Antonio Sotratti, "Turismo cultural e patrimônio cultural: aproximações e contrastes", que aborda as estratégias de marketing direcionadas à potencialização do patrimônio cultural como atrativo turístico e o fato de que o turismo cultural vem apresentando 
resultados satisfatórios nas análises oficiais de organizações voltadas à mensuração dos impactos econômicos e sociais da atividade.

Está também, nessa primeira parte, o ensaio da professora Clara Carvalho de Lemos, "A inserção da variável ambiental no planejamento turístico: por uma abordagem estratégica”, que visa reforçar a necessidade de se buscar formas de inserir a variável ambiental em ações de planejamento do turismo e considera que a pesquisa sobre o tema ainda é limitada. Lemos nos alerta que, apesar de já existir alguma experiência e prática internacionais no que diz respeito à abordagem estratégica dos impactos ambientais do turismo - em especial no âmbito de políticas, planos e programas -, no Brasil essa discussão ainda é recente, dado que o gerenciamento de impactos acontece em momentos tardios; ou seja, o estímulo ao turismo precede o planejamento, e o poder público, geralmente, concentra esforços em minimizar os impactos que o aumento do fluxo turístico causa em áreas naturais, desconsiderando outras consequências inevitáveis que essa atividade pode trazer para uma região, como a pressão sobre o arranjo territorial, a pressão sobre os recursos naturais e as reservas de água, o aumento da produção de resíduos e efluentes etc. Tendo em vista, portanto, a necessidade de pesquisa em abordagens estratégicas na gestão dos impactos negativos da atividade, este trabalho oferece alguns subsídios e reflexões para o tratamento dessas questões, especialmente no contexto brasileiro.

O texto do professor Rafael Ângelo Fortunato, "Turismo solidário: em busca de um conceito", procura lançar questões para aquecer o debate sobre as potencialidades do turismo em promover transformações sociais por meio de uma reflexão crítica sobre as relações interpessoais permeadas pela ideia de solidariedade, bem como a tentativa de entender como o turismo solidário aparece em sítios eletrônicos no mundo.

O quarto ensaio, "Turismo e saúde: discussão de uma política de saúde do viajante no Brasil", é de autoria de Vanina 
Matos e Christovam Barcellos, que buscaram, junto aos gestores públicos de saúde e de turismo, propostas para efetivar uma política de saúde do viajante no Brasil. O encaminhamento do trabalho se deu por meio de uma pesquisa qualitativa com gestores do setor da saúde e do turismo que atuam no Rio de Janeiro nos níveis municipal e estadual, e gestores do nível nacional, selecionados para uma entrevista sobre a discussão de uma política nacional de saúde do viajante/turista. A amostra não probabilística se constituiu de 16 entrevistas, e os dados foram coletados por meio de um roteiro semiestruturado. Para sistematização dos resultados, foi utilizada a análise de conteúdo de base temática, e a categoria informação emergiu para a discussão subdividida em "informação sobre o turista", "sistema de informação" e "informação para o turista". Prevalece no aprofundamento da questão, contudo, a falta de informação sobre o turista. Não se conhece seu perfil epidemiológico nem na morbidade, nem na mortalidade. No Brasil, as políticas públicas de saúde têm um sistema de priorização, pensado principalmente com base nos óbitos. A dicotomia de uma política específica ou transversal para o viajante/turista transitou ora pela condição circunstancial de turista, ora pela emergência do controle de fronteiras e o sucesso dos eventos de massa.

Encerrando essa parte, o estudo da professora Amanda Danelli Costa, "História e cultura urbana carioca: a natureza turística do Rio de Janeiro entre a cidade das letras e a cidade maravilhosa", analisa como a cidade do Rio de Janeiro é, nos dias de hoje, uma imagem vinculada e veiculada exclusivamente aos aspectos positivos da vida - ativa e, sobretudo, contemplativa - na zona sul e no centro da cidade. Entre os anos 1900 e 1930, entretanto, ela foi fruto da intervenção da cidade das letras. Não apenas porque o epíteto tenha surgido nos contos de Coelho Neto, literato muito presente na imprensa carioca, mas porque o estilo de vida corrente nos bairros atlânticos não era - como o mar, a praia, os morros - uma natureza. $\mathrm{O}$ que se tornou a forma corrente de frequentar as praias foi ensinado 
ao carioca pela coluna "Iracema", na Revista da Semana, entre os anos 1914 e 1917. O aprendizado das sociabilidades na praia foi feito a exemplo das experiências de sucesso dos balneários europeus, visando à associação entre a valorização dos atributos naturais dos bairros atlânticos cariocas e a uma ocupação suntuosa e elegante.

Na segunda parte, "Turismo e desenvolvimento territorial na Itália”, as diversas abordagens se voltam para um denominador comum: a importância do planejamento na dinâmica socioespacial dos territórios. Nesse sentido, o ensaio de Marina Faccioli, "Problematiche territoriali del turismo a Roma: due casi di studio", se concentra na discussão sobre os novos valores do turismo no território e em suas implicações no processo de planejamento, tomando como referências de análise Castelli Romani, área antiga de Roma em franco processo de renovação urbana, e a tradicional área portuária de Óstia, região que conjuga excepcionais recursos arqueológicos e intensa ocupação de equipamentos balneários.

A análise da professora Paola Nicoletta Imbesi, "Il Lago di Como: i molti turismi di un territorio turistico", aborda a problemática do desenvolvimento e da expectativa de resultados da implantação do turismo no território frente à complexidade e riqueza socioespacial presente nessa categoria geográfica. Sua abordagem, evidenciando as relações do turismo e território e do território e turismo, é exemplificada com o caso do Lago di Como, região de alta relevância paisagística e territorial no norte da Itália.

A discussão sobre novas formas de planejar o desenvolvimento turístico, desenvolvida pela professora Francesca Spagnuolo no texto "Un nuovo modo di pianificare il processo di sviluppo turistico", é baseada em duas premissas contemporâneas de se pensar o planejamento turístico: a primeira exige um conhecimento holístico e intenso dos processos territoriais locais; a segunda exige uma programação e organização da atividade a partir das transformações sociais, políticas, econômicas e culturais ocorridas no território em que o turismo se desenvolve. A escala local é evidenciada pela autora 
como unidade de análise, interpretação e projeto, devendo orientar os processos de desenvolvimento turístico contemporâneos.

O ensaio de Anna Tanzarella, "La declinazione della sostenibilità al turismo", aborda as premissas conceituais e os desafios do desenvolvimento turístico frente à necessidade contemporânea de sustentabilidade econômica, social e ambiental da escala local. Essa compreensão permite o avanço e a aproximação do desenvolvimento sustentável ao turismo por meio da denominação "turismo sustentável", que incorpora valores de equilíbrio ambiental ao crescimento econômico consciente e à ética social e cultural. Sua discussão acerca da busca da sustentabilidade na escala local contribui para a reflexão dos processos de planejamento territorial do turismo e para a formulação de políticas públicas que procuram a inserção competitiva das localidades nos processo globais sem perder suas características paisagísticas, sociais e econômicas que orientaram o desenvolvimento do território.

Por fim, Alessandro Macchia, em "Come spremere acqua dalle pietre: un progetto a $360^{\circ}$ - il caso dell'Orto dei Tu'rat come fattore ambientale e turístico", apresenta um projeto desenvolvido na região italiana de Basso Salento, mais especificamente no Parque Orto dei Tu'rat, que analisa a perda de água e o crescente processo de erosão, desertificação e salinização ocasionado por intensas explorações econômicas no entorno do parque. Por meio de técnicas criativas e tradicionais locais, bem como de experiências de comunidades externas que vivenciaram o mesmo problema ambiental, o Parque Orto dei Tu'rat busca dar uma resposta aos problemas ambientais existentes e ainda demonstrar a importância da requalificação territorial e da integração da comunidade nos processos de gestão local. 


\section{Parte 1 \\ Novos olhares do turismo no território brasileiro}




\section{Turismo cultural e patrimônio cultural: aproximações e contrastes}

Marcelo Antonio Sotratti

A discussão acerca da relação entre o patrimônio cultural e o turismo pode ser constatada em praticamente toda a trajetória de construção do campo de pesquisa e gestão do patrimônio cultural. Seja por meio de ações diretas ou indiretas, de políticas públicas de valorização dos bens culturais, ou por meio de pesquisas acadêmicas, o turismo sempre se mostrou como uma atividade importante de apropriação de bens culturais de alto valor simbólico.

A relação entre patrimônio cultural e turismo sempre acarreta transformações simbólicas e mesmo físicas nos bens culturais. A apropriação do patrimônio como atrativo turístico, sua refuncionalização turística para hotelaria, gastronomia e eventos exige, muitas vezes, intervençóes arquitetônicas que venham a adequar os usos contemporâneos desses objetos antigos agora ligados a outro contexto socioespacial. Da mesma forma, a museificação do patrimônio cultural para fins turísticos e a cenarização de fachadas para a composição de centros históricos turistificados pode levar a transformações simbólicas significativas, reduzindo o valor sim- 
bólico de tais bens a um pano de fundo ou chamariz para atividades de consumo e lazer.

Nesse sentido, várias críticas e proposições de interação acerca da relação entre o patrimônio cultural e o turismo vêm sendo elaboradas por países líderes no mercado turístico e na construção e valorização do patrimônio cultural. Para esses países - como a Espanha -, as formas de gestão são fundamentais para minimizar os efeitos negativos do turismo em bens culturais consagrados. No mesmo sentido, a adoção de um turismo cultural adequado, controlado e voltado à educação e valorização patrimonial tem se tornado uma alternativa interessante em locais em que o turismo de massa vem se apropriando intensamente.

Centrado nessa questão, este capítulo apresenta algumas discussões teóricas e experiências internacionais na aproximação entre o patrimônio cultural e o turismo, mostrando faces de aproximação importantes e alguns cuidados a se atentar na gestão e apropriação do turismo em áreas ou objetos de alto valor cultural.

\section{O turismo cultural como forma de apropriação do patrimônio cultural: vontades e desafios}

Como efeito de estratégias de marketing direcionadas à potencialização do patrimônio cultural como atrativo turístico, o turismo cultural vem apresentando resultados satisfatórios nas análises oficiais de organizações voltadas à mensuração dos impactos econômicos e sociais da atividade, como a Organização Mundial de Turismo (OMT; Richards, 2009, p. 25).

Estudos teóricos sobre o segmento, como aqueles desenvolvidos por McKercher e Du Cros (2002), Richards (1996, 2009), Vaquero e Hernández (1998), ressaltam a projeção do turismo cultural nos últimos anos, ampliando a gama de possibilidades e caminhos da atividade turística nas cidades e sítios providos de recursos culturais de diferentes naturezas. Tais trabalhos assinalam 
ainda a importância da organização e especialização de diferentes segmentos na atividade turística, dentre eles o turismo cultural, no qual espaços e paisagens planejados e orientados para públicos específicos vêm adquirindo expressividade econômica e simbólica no panorama turístico internacional, diversificando o antigo modelo massificado do turismo de sol e praia.

Segundo Richards (2009, pp. 25-6), o turismo cultural reflete um turismo de melhor qualidade, no qual as expressões culturais locais podem ser valorizadas e inseridas na economia local. Entretanto, segundo o autor, essa possibilidade não se caracteriza como uma condição onipresente em todos os destinos culturais, uma vez que a massificação e a turistificação de bens culturais representa atualmente uma possível ameaça à permanência e originalidade de tais bens.

Mesmo observando a preocupação em manter os aspectos originais e a diversidade que caracteriza a oferta cultural desse segmento, constata-se, na maioria dos trabalhos voltados ao turismo cultural, a valorização de bens culturais materiais e consagrados como patrimônio cultural como os principais atrativos turísticos a serem estruturados, organizados e promovidos pelos gestores públicos e privados do turismo. Essa seletividade espacial e econômica é percebida claramente nos conceitos de turismo cultural apresentados por organizaçôes e por alguns teóricos internacionais voltados à pesquisa desse segmento.

A primeira carta do International Council on Monuments and Sites (Icomos) voltada ao turismo cultural (1976) ressalta que esse segmento se apresenta como uma forma de turismo que tem como objetivo o conhecimento de monumentos e sítios históricos e artísticos, visando ainda à sua manutenção e proteção. Em sua segunda carta sobre o segmento, o Icomos (1999) declara o patrimônio cultural como um dos maiores atrativos do turismo no período da globalização, constituindo-se na base do desenvolvimento social e da diversidade cultural. 
O próprio Ministério do Turismo (2010, p. 16), em parceria com o Instituto do Patrimônio Histórico e Artístico Nacional (IPHAN), apresenta uma definição de turismo cultural pautada na vivência de elementos que compreendem o patrimônio histórico e cultural, bem como os eventos culturais. Observa-se, por esse documento, que o conceito de patrimônio cultural adotado pelo ministério é o mesmo utilizado pelo IPHAN, ao considerar patrimônio histórico e cultural bens de natureza material ou imaterial que expressam ou revelam a memória e a identidade das populações e comunidades (Ministério do Turismo, 2010, p. 17). Esses bens, segundo a instituição, possuem valor histórico, artístico, científico e simbólico e são passíveis de se tornarem atrativos culturais voltados à vivência e à contemplação.

Para Richards (2009, p. 26), o conceito de turismo cultural vai além da apropriação turística do patrimônio cultural. Segundo o autor, o turismo cultural representa o resultado de uma motivação específica, no caso, a busca de turistas por experiências culturais de diferentes naturezas, como viagens de estudo, festivais musicais, peregrinações ou mesmo visitas a centros históricos e monumentos. A compreensão do segmento turismo cultural deve ser focada no olhar do turista e de suas múltiplas motivações culturais e não simplesmente na apropriação turística do patrimônio cultural. Nesse sentido, o conceito de turismo cultural envolve aspectos específicos que revelam as diferentes possibilidades de análise que caracterizam o segmento: “aspectos turísticos, apropriação de bens culturais, consumo de experiências e produtos, motivações dos turistas" (McKercher e Du Cros, 2002, pp. 3-6).

Analisar o segmento do turismo cultural sob a ótica da atividade turística acarreta, segundo os autores, a priorização dos resultados econômicos e sociais de determinado bem cultural em detrimento de ações que visem à sua proteção e valorização. Nesse caso, o turismo cultural se resumiria a uma estratégia de direcionamento de produtos turísticos de natureza cultural a potenciais 
consumidores. As empresas turísticas, almejando melhor posicionamento de mercado junto à concorrência, criam novos produtos, com o objetivo de suprir as necessidades e os desejos dos turistas contemporâneos. Assim, o bem cultural passa a exigir infraestrutura específica e intensamente renovada para se transformar num atrativo cultural que o insira no cenário de prestígio internacional.

Ações públicas e privadas que pretendem acessibilidade, informação e consumo de subprodutos ligados à atividade turística - como eventos, souvenires e gastronomia - se aliam fortemente aos atrativos culturais contemporâneos, criando um produto de forte apelo econômico e mercadológico. O Museu de Arte Moderna de Nova York (MOMA) passou recentemente por uma ampla reforma e tornou-se uma grande referência para todos os museus internacionais; nele, a intensa programação cultural, as lojas, os restaurantes e os cafés complementam seu rico acervo de arte moderna, o que o transforma num grande complexo cultural e turístico. Para Ohtake, a modernização de bens culturais, como aquela observada em diversos museus internacionais, reflete a necessidade contemporânea de agregar a cultura à dinâmica e aos hábitos da cidade contemporânea. Segundo o autor, os equipamentos culturais das atuais metrópoles funcionam como "atrações nucleares" para o avanço do setor de serviços e para novas formas de gestão urbana (2000, pp. 111-2).

O mesmo resultado se observa nos projetos de refuncionalização de centros históricos implantados em diversas cidades europeias, americanas e mesmo brasileiras. Como já discutido, os usos econômicos, sobretudo o comércio e os serviços turísticos, representam um forte elemento de valorização e ressignificação do patrimônio cultural em tais áreas, transformando-o em atrativo de forte apelo publicitário e econômico.

Observa-se, dessa forma, que o turismo cultural analisado pela ótica da atividade turística ratifica a visão mercantilista dos agentes responsáveis pelo segmento em relação ao patrimô- 
nio cultural. $\mathrm{O}$ patrimônio cultural material assume importância diferenciada, já que possibilita novos direcionamentos na dinâmica econômica e imobiliária dos espaços urbanos em que estão inseridos, em vez de possibilitar a preservação das diferenças sociais que identificam e singularizam esses espaços (Marins, 2004).

A apropriação dos bens culturais, como assinalam McKercher e Du Cros (2002, pp. 3-6), consiste em outra referência de análise da relação entre o turismo e o patrimônio cultural. Segundo os autores, a tradição europeia de gestão do patrimônio resultou, muitas vezes, no distanciamento entre as populaçóes residentes e visitantes e o patrimônio cultural de determinado lugar. Esse distanciamento reflete o processo elitista que envolve a definição do patrimônio cultural a ser preservado, bem como suas possíveis formas de apropriação.

O tombamento, por exemplo, surge como um recurso que garante a manutenção de marcos significativos em determinado espaço urbano e se caracteriza como um processo autocrático e tecnocrático distante da participação popular. A atuação civil se limita a reivindicaçóes para o tombamento de alguns bens simbólicos de interesse coletivo ou a instrumento de pressão política utilizado estrategicamente pelos órgãos de preservação.

Nesse sentido, o turismo cultural colabora com uma apropriação coletiva mais intensa do patrimônio cultural. O turismo possibilita a valorização de bens culturais desconsiderados ou não priorizados pelos órgãos de preservação, como o patrimônio imaterial e o patrimônio cultural material móvel de origem popular (McKercher e Du Cros, 2002, p. 7). A aproximação do patrimônio cultural e do turismo como forma de valorização e apropriação coletiva, independente das relações mercadológicas priorizadas pelos gestores do turismo, vem sendo tratada largamente em diversos países. A análise bibliográfica acerca dessa aproximação realizada na Espanha, por exemplo, demonstra a importância do 
turismo como atividade potencialmente parceira e convergente aos princípios de proteção do patrimônio cultural.

\section{O exemplo espanhol da aproximação entre turismo e patrimônio cultural}

Para Vaquero e Hernández (1998, pp. 249-53), a emergência do turismo cultural vem possibilitando a recuperação física do patrimônio e o desenvolvimento econômico e social de diversas cidades espanholas. Embora a aproximação do turismo e do patrimônio cultural apresente dificuldades e ofereça diversos riscos à vitalidade urbana e social dessas cidades, a implementação de um turismo cultural baseado na pluralidade, ou seja, na apropriação turística diferenciada em diferentes naturezas de bens culturais, vem se mostrando eficaz como ferramenta de desenvolvimento econômico e social de cidades dotadas de relevante patrimônio cultural. Da mesma forma, o turismo cultural na Espanha vem assumindo um papel fundamental na consolidação de valores protecionistas e identitários do patrimônio cultural entre os moradores locais, favorecendo a participação democrática nos processos de gestão dos bens culturais e das cidades como um todo.

Hernández (2007) relata ainda que o turismo cultural na Espanha vem apresentando mudanças significativas nos últimos anos. Segundo a autora, as cidades espanholas dotadas de patrimônio cultural reconhecido pela Organização das Nações Unidas para a Educação, a Ciência e a Cultura (UNESCO) passaram décadas desenvolvendo uma atividade turística baseada unicamente na promoção e implantação de infraestrutura pontual em atrativos de alta repercussão. No entanto, nos últimos anos, o patrimônio cultural vem sendo alvo de processos mais amplos de gestão, envolvendo redes de agentes e açôes que visam associar a presença do patrimônio da humanidade e do turismo cultural ao processo de desenvolvimento global dessas cidades. Conselhos 
de turismo e patrimônio, parcerias público-privadas, consórcios e patrocínios empresariais para a recuperação física do patrimônio e organismos mistos de gestão do turismo são alguns exemplos de sucesso apontados pela autora (pp. 81-5).

Para García (2007), o processo amplo e integrado de gestão do patrimônio cultural e do turismo ainda não é realidade absoluta nas cidades espanholas. Localidades importantes, como El Real Sítio de San Lorenzo del Escorial, nas proximidades da região metropolitana de Madri, ainda sofrem problemas significativos de entendimento entre os órgãos de proteção do patrimônio e os órgãos de turismo. A apropriação turística restrita aos bens patrimoniais e a fraca influência do órgão de turismo no desenvolvimento da cidade vêm dificultando a participação efetiva da localidade como oferta turística complementar da região metropolitana de Madri (2007, pp. 90-1; 95-6).

No mesmo sentido, a relação entre patrimônio cultural e turismo na Espanha vem apresentando, de acordo com González, divergências e convergências significativas que devem ser consideradas nos processos de gestão do turismo cultural. Segundo ela, quando incorporado pelo sistema turístico, o patrimônio cultural se transforma em produto e automaticamente passa por intensa apropriação com perfis de turistas adversos aos pretendidos pelos gestores do patrimônio. Os valores simbólicos e o interesse público valorizados pelos órgãos de proteção do patrimônio antepõem-se ao valor de uso e ao interesse econômico da indústria do turismo, gerando conflitos políticos e ideológicos que afastam os bens culturais das agendas de desenvolvimento local (2009, pp. 240-2).

Ao mesmo tempo, o alto grau de competitividade e a crescente variação nos perfis de turistas observados nos destinos culturais espanhóis vêm favorecendo a aproximação positiva entre a gestão do patrimônio cultural e o turismo. A necessidade da criação de produtos originais, criativos e singulares tem, por um lado, possibilitado a apropriação diferenciada do patrimônio cultural, 
em que seu valor simbólico original passa a ser considerado o principal fator de atratividade turística. Por outro lado, a presença de turistas culturais de diferentes idades, motivaçōes e formação socioeconômica exige a apropriação ampliada e diversificada do patrimônio cultural em suas diversas naturezas (González, 2009, pp. 243-5).

As dificuldades de projeção do turismo como principal atividade de proteção e valorização do patrimônio cultural em cidades pequenas e médias são consideradas por Vinuesa (2002) ao analisar o caso de Aranjuez. $\mathrm{O}$ autor assinala que a proximidade dessa cidade patrimônio e Madri dificulta uma apropriação prolongada e diferenciada por parte dos turistas. Normalmente excursionistas, os visitantes em Aranjuez acabam se limitando à contemplação das fachadas do centro histórico, a algumas lojas e restaurantes e a visitas guiadas aos principais atrativos culturais da cidade. Os altos investimentos em turismo cultural acabam gerando, muitas vezes, processos econômicos especulativos que depreciam a tradição cultural da cidade. Para o autor, esforços na refuncionalização urbana do centro histórico, contemplando diversidade de usos e novos perfis de turistas culturais, vêm sendo adotados pela municipalidade de Aranjuez e denotam o interesse local em centralizar o patrimônio como elemento de desenvolvimento urbano (2002, pp. 514-5).

Esse fato é ratificado por López (2005, pp. 338-9; 342-4) ao afirmar que a inserção diferenciada do patrimônio no território deve ser considerada nos processos de gestão do turismo cultural. Ao analisar o caso espanhol, o autor considera as diferenças simbólicas, geográficas, paisagísticas e econômicas exercidas pelo patrimônio em metrópoles, cidades litorâneas, centros históricos e vilarejos nos processos de planejamento urbano e turístico desses locais. No caso de Toledo, sua condição paisagística, infraestrutural e cultural favorece o turismo como fator de desenvolvimento global da cidade, trazendo possibilidades de investimentos públi- 
cos e privados que minimizem os problemas urbanos identificados atualmente.

No caso de Barcelona, o patrimônio como elemento de representação simbólica transcendeu o centro histórico e a arquitetura icônica de Gaudí ao incorporar novas referências espaciais e paisagísticas associadas aos subsequentes processos de refuncionalização urbana observados na cidade desde o período dos Jogos Olímpicos de 1992. A relação entre o patrimônio cultural e o turismo, nesse caso, consiste na transformação dos valores atribuídos aos bens culturais, direcionados então a um universo de consumo lúdico, turístico e cultural. Essa transformação, iniciada e consagrada pelo marketing urbano internacional, eleva o patrimônio ao status de referência estilística para a criação de simulacros e novos ícones na paisagem urbana (Léon e Aguilar, 2009, pp. 6-7).

Segundo Léon e Aguilar, o julgamento crítico da refuncionalização e da espetacularização do patrimônio cultural em Barcelona o coloca como centro de discussão no processo de planejamento urbano da cidade, independentemente de seus resultados. Esse fato ressalta a importância de considerarmos os contextos e possibilidades de apropriação turística do patrimônio cultural e não a adoção simplista e generalizada de modelos estrangeiros, como ocorreu com o modelo Barcelona em outras cidades europeias e latino-americanas.

Outro exemplo espanhol a se considerar é o caso de Sevilha. Para Gomez e Rúbio (1999), Sevilla é um exemplo representativo de turismo cultural exercido em cidades médias do Sul da Europa, onde a articulação da cidade com o mercado turístico nacional e internacional não foi suficiente para alterar a estrutura e o valor simbólico do patrimônio cultural local.

Segundo os autores, o turismo cultural deve ser pensado de forma estratégica, englobando toda a região metropolitana andaluza. A infraestrutura urbana de Sevilha, seu riquíssimo patrimônio cultural e a complementação patrimonial exercida potencial- 
mente pelas cidades de entorno possibilitam um desenvolvimento integrado e distribuidor de fluxos turísticos em toda a região metropolitana, favorecendo a modernização e consolidação de toda a comunidade autônoma no cenário turístico e urbano nacional e internacional (pp. 40-5).

Observa-se pelos exemplos espanhóis aqui considerados que não existe consenso em relação às benesses da aproximação do turismo e do patrimônio cultural. Embora exaltados como uma aproximação positiva, os exemplos espanhóis demonstram que a relação entre os bens culturais e o turismo deve extrapolar os resultados econômicos esperados pela iniciativa privada, incorporar-se nos processos de planejamento global das cidades e, ainda, incentivar a formação de redes sociais entre os diferentes agentes envolvidos na gestão do turismo e do patrimônio cultural.

\section{A apropriação turística do patrimônio na globalização: novas possibilidades, novos problemas}

Da mesma forma, observa-se que as diferentes possibilidades de apropriação, a forte concorrência entre cidades e, sobretudo, a condição espacial em que se encontra o patrimônio cultural devem ser consideradas nos processos de gestão de tais bens, excluindo a adoção de modelos engessados de refuncionalização turística. Por fim, a promoção exacerbada do patrimônio cultural para fins turísticos, normalmente acompanhados de infraestrutura massificada e especializada, não corresponde aos exemplos exitosos de turismo cultural nas cidades espanholas, devendo ser analisados e investigados os exemplos de processos de gestão integrada e participativa em cidades nas quais o patrimônio consiste no principal recurso de desenvolvimento.

Em continuidade aos parâmetros de análise entre o patrimônio cultural e a atividade turística indicados por McKercher e Du Cros (2002, pp. 3-6), a vivência e o consumo de novas experiências 
pessoais caracterizam o segmento do turismo cultural. A relação entre os bens culturais e os turistas pode ir além da mera contemplação, possibilitando a expansão do conhecimento individual e o despertar de novos valores pessoais, transformando os turistas em agentes ativos na proteção e valorização do patrimônio cultural.

Uma das formas mais comuns em estabelecer um processo de comunicação interativo entre os turistas e o patrimônio cultural é a interpretação. Segundo Murta e Goodey (2002, p. 13), a interpretação do patrimônio consiste em ações de comunicação entre os elementos culturais e os visitantes por meio de textos, imagens ou outras representaçôes, possibilitando melhor aproveitamento ou experiência no local visitado.

A interpretação do patrimônio no turismo cultural acrescenta valor ou intensifica a experiência do turista em determinado atrativo, uma vez que alia o entretenimento ao conhecimento mais profundo dos bens culturais. Nesse sentido, a interpretação consiste em uma forte aliada às ações da educação patrimonial, já que, por meio de uma visita orientada e controlada, pode distribuir o fluxo de visitantes em determinado local e, ao mesmo tempo, sensibilizá-los em relação à proteção dos objetos da visita (pp. 14-5).

$\mathrm{O}$ uso de novas tecnologias em processos de interpretação do patrimônio vem assumindo grande expressividade nas atividades de educação patrimonial pelo turismo, visto que, ao empregar linguagens inovadoras e de fácil percepção e assimilação, potencializa a relação entre entretenimento e conhecimento que caracteriza os produtos turístico-culturais. Guias eletrônicos, painéis multimídia, projeções e instalações interativas vêm substituindo as tradicionais sinalizações informativas presentes nos museus e centros históricos. No entanto, o emprego excessivo de recursos midiáticos e informacionais em bens culturais para fins turísticos pode levar a processos de espetacularização de tais bens, ampliando a atenção dos visitantes para outros recursos visuais e comprometendo os objetivos da educação patrimonial (Manzato, 2007, pp. 103-4). 
Exemplos extremos de interpretação do patrimônio, como a ambientação de base histórica, recriam ambientes e situações cotidianas de um tempo pretérito para a experiência e contemplação de turistas. Segundo Pires (2001, pp. 57-8; 60-1), a ambientação de base histórica utiliza recursos como cenografia, vestuário, iluminação, música, alimentação e dramatização para o aproveitamento de bens culturais para o turismo e o lazer, criando uma atmosfera imaginária realista do ambiente original que compreende o patrimônio em questão. Para o autor, a ambientação de base histórica consiste num poderoso recurso de marketing turístico voltado à apropriação turística de bens culturais que eleva o patrimônio à condição de bem dinâmico e interativo entre passado e presente. Os exemplos do chamado triângulo histórico americano, que compreende as cidades de Williamsburg, James City e Yorktown, todas no estado da Virgínia, são referências importantes dessa técnica de interpretação do patrimônio.

A discussão pertinente de Gonçalves acerca de patrimônio, memória e autenticidade antepõe-se às colocações de Pires (2001). Segundo o autor, a recriação paisagística e cenográfica de Williamsburg assume um aspecto dramático de reencenação, congelando um passado idealizado e inerte às inter-relações com os turistas ali presentes. Para Gonçalves,

o conjunto urbanístico e arquitetônico [de Williamsburg] e mais a performance dos atores não sugerem antiguidade, mas, sim, o aspecto novo e limpo, quase asséptico, das coisas recriadas. [...] Em Colonial Williamsburg esses prédios e objetos não parecem vir de nenhum passado, mas, antes, de um eterno presente. $\mathrm{O}$ desaparecimento da 'aura', de que nos fala Benjamin, parece aqui ter atingido um limite extremo (1988, p. 271).

Nesse caso, os simulacros e as encenações observadas em tais atrativos culturais são utilizados pelo marketing turístico 
como sinônimo de autenticidade, na tentativa de atrair um número cada vez maior de turistas e visitantes. No entanto, as características atemporais e assépticas de tais atrativos contrariam, como exposto por Gonçalves, os preceitos de Walter Benjamin acerca da autenticidade dos bens culturais. Se pensarmos em nossa opção fachadista no tombamento de sítios históricos como um recurso suficiente à preservação da memória, podemos nos questionar se não estamos agindo como uma mera ambientação ao reduzir o patrimônio a um cenário desarticulado da dinâmica urbana das localidades.

A ambientação de base histórica, bem como outros exemplos de técnicas de interpretação do patrimônio que se sobrepõem aos objetivos e interesses da educação patrimonial, transforma, segundo McKercher e Du Cros (2002, p. 8), o patrimônio cultural em produtos turísticos. Esses produtos, ao agregarem elementos de comunicação e infraestrutura notadamente voltadas ao entretenimento e ao valorizar suas características superficiais e incentivar a compra incessante de subprodutos associados a tais características, como souvenires, gastronomia e eventos culturais paralelos, enaltecem o poder de consumo dos bens culturais. Na maioria das vezes, tais subprodutos exercem poder de atratividade maior que o próprio bem cultural e reduzem o patrimônio cultural a mero elemento indutor e ambientador para consumo turístico e lúdico. Associar a atividade turística à condição de atividade facilitadora e promotora de valorização e proteção do patrimônio cultural por meio de experiências e ações interpretativas requer uma revisão profunda acerca dos interesses do marketing turístico ao transformar o patrimônio cultural em produto de consumo turístico. Essa transformação pode levar, num curto período de tempo, à aceleração do processo de degradação e especulação dos bens e espaços culturais e ao surgimento de um turismo massificado e distanciado dos preceitos do turismo cultural. 
Por fim, o último elemento de análise sobre a relação entre o patrimônio e o turismo assinalado por McKercher e Du Cros (2002, pp. 3-6) refere-se à motivação dos viajantes no turismo cultural. Analisando os conceitos relativos ao segmento expostos no início deste capítulo, como os apresentados pelo Icomos e pelo Ministério do Turismo, constata-se a existência de uma visão idealizada do turista cultural. A partir desses conceitos, imagina-se um turista cultural que busca experiências diferenciadas e conhecimentos profundos do patrimônio durante sua visitação turística. No entanto, pesquisas realizadas por instituiçôes europeias e americanas demonstram a existência de uma variedade considerável de motivações e tipos de turistas que buscam esse segmento, incluindo muitas vezes experiências consumistas e superficiais.

Diversos autores discutem as diferenças comportamentais dos turistas culturais nos destinos. Tais diferenças comportamentais se baseiam no nível de informação exigido pelos turistas quando visitam determinados atrativos ou destinos culturais e no papel desempenhado pela cultura na definição da viagem ou de atrativos que os turistas queiram conhecer em destinos turísticos (WTO e ETC, 2005).

Hábitos de viagem desenvolvidos pelos turistas culturais também se adequam ao perfil dos turistas desse segmento. A preparação da viagem, por exemplo, é fundamental para os turistas culturais, uma vez que o conhecimento prévio sobre a história e os modos de vida da população que vive nos destinos favorece a interpretação dos atrativos quando visitados. Nesse sentido, Richards (1996, pp. 32-4) aponta o papel que a internet vem desempenhando na preparação da viagem e a importância que os destinos têm na organização e divulgação eletrônica de sites especializados e dirigidos ao turismo cultural.

Mesmo buscando antecipadamente informações e conhecimento acerca dos atrativos culturais a serem visitados, os turistas culturais não apresentam, em sua maioria, motivaçôes específicas. 
Segundo Richards (1996, p. 38), somente $10 \%$ dos turistas denominados culturais viajam com motivação específica em visitar determinado tipo de patrimônio; a maioria, no entanto, busca conhecimento geral e amplo acerca do patrimônio cultural existente em determinado destino.

\section{Considerações finais}

Estas análises nos remetem à reflexão do real valor da atividade turística nos processos de gestão e proteção do patrimônio cultural. O turismo, comumente sacralizado como a melhor alternativa de valorização econômica, urbana e cultural do patrimônio, vem demonstrando sua ineficácia e despreparo na identificação e condução dos valores simbólicos e do papel dos bens culturais nas cidades em que a atividade se desenvolve.

O envolvimento da comunidade nos processos de gestão do patrimônio deve assumir um papel central nas discussões acerca do futuro de tais bens e incorporar-se nas ações de preservação e apropriação do patrimônio cultural. Da mesma forma, as transformaçôes simbólicas induzidas pela indústria do turismo e os novos anseios de consumo por parte dos turistas ditos culturais dificultam ações de gestão que venham a envolver os visitantes e moradores na proteção dos bens. A apropriação vertical de centros históricos por empresas transnacionais na construção de hotéis, resorts e centros gastronômicos vem acarretando graves processos de gentrificação e exclusão da população local, reduzindo o patrimônio num elemento de alto valor especulativo e de marketing.

Por outro lado, tais constatações têm alimentado o campo da pesquisa do patrimônio cultural e o papel da ciência geográfica na análise da aproximação entre o turismo e patrimônio cultural. Identificar os usos sociais e sua relação com os bens culturais vem gerando pesquisas acadêmicas referenciais para a minimização de efeitos negativos dessa relação, as quais se tornam também im- 
portantes instrumentos para a construção de políticas públicas de turismo e patrimônio e de práticas de gestão.

\section{Referências}

BRASIL. "Turismo cultural: orientações básicas". 3 ed. Brasília: Ministério do Turismo, 2010.

GARCÍA, Maria del Carmen Mínguez. "Planificación y gestíon turística en destinos patrimoniales: el caso del Real Sítio de San Lorenzo del Escorial (Comunidad de Madrid)". Anales de Geografia, Madri, jan.-jun. 2007, v. 27, n. 1, pp. 83-102.

GOMEZ, Manuel Marchena e RÚBIO, Fernando Repiso. "Turismo cultural: el caso de Sevilla”. Cuadernos de Turismo, Murcia, jul.-dez. 1999, n. 4, pp. 33-50.

GONÇALVES, José Reginaldo. "Autenticidade, memória e ideologias nacionais: o problema dos patrimônios culturais". Estudos Históricos, Rio de Janeiro, 1988 , v. 1, n. 2, pp. 264-75.

GONZÁLEZ, María Velasco. "Gestión turística del patrimonio cultural: enfoques para un desarollo sostenible del turismo cultural". Cuadernos de turismo, Murcia, jan.-jun. 2009, n. 23, pp. 237-53.

HERNÁNDEZ, María García. "Entidades de planificación y gestión turística a escala local: El caso de las ciudades patrimonios de la humanidad en España”. Cuadernos de turismo, Murcia, jul.-dez. 2007, n. 20, pp. 79-102.

ICOMOS. "Charter of cultural tourism". Bruxelas, 1976. Disponível em http:// www.icomos.org/tourism/tourism_charter.html. Acesso em mai. 2010.

-."Carta internacional sobre turismo cultural. La gestión del turismo en los sítios com património significativo”. México, 1999. Disponível em http://www.international.icomos.org/charters/tourism_sp.htm. Acesso em mai. 2010.

LÉON, Aurora García de e AGUILAR, Alejandro Duarte. "Turismo cultural en Barcelona: marketing de ciudad y arquitectura icônica". Topofilia: Revista de Arquitectura, Urbanismo y Ciencias Sociales, Sonora, abr. 2009, v. 1, n. 3, pp. 1-15.

LÓPEZ, Alejandro. "Desarrollo sostenible: medioambiente y turismo en las ciudades históricas: el caso de Toledo". Observatório Medioambiental, Madri, 2005, n. 8, pp. 331-44. 
MANZATO, Fabiana. "Turismo arqueológico: diagnóstico e análise do produto arqueoturístico". Revista Pasos - Revista de Turismo y Património Cultural, Santa Cruz de Tenerife, abr. 2007, v. 5, n. 1, pp. 99-109.

MARINS, P. C. G. "Requalificação de áreas urbanas no Brasil: caminhos para um balanço crítico em relação às práticas de lazer e turismo". Patrimônio. Lazer \& Turismo, Santos, mar. 2004, v. 1, n. 1, s. p.

McKERCHER, Bob e DU CROS, Hilary. The partnership between tourism and cultural heritage management. Nova York: Routledge, 2002.

MINISTÉRIO DO TURISMO. Turismo cultural: orientaçōes básicas. 3 ed. Brasília, 2010.

MURTA, Stela Maris e GOODEY, Brian. "Interpretação do patrimônio para visitantes: um quadro conceitual”. In MURTA, Stela Maris e ALBANO, Celina. Interpretar o patrimônio: um exercício do olhar (orgs.). Belo Horizonte: EdUFMG, 2002.

OHTAKE, Ricardo. "Os novos monumentos da metrópole". São Paulo em Perspectiva, São Paulo, out.-dez. 2000, v. 14, n. 4, pp. 111-9.

PIRES, Mário Jorge. Lazer e turismo cultural. São Paulo: Manole, 2001.

RICHARDS, Greg. Culture tourism in Europe. Oxon: CAB International, 1996.

- Cultural tourism. Global and local perspectives. Nova York: Routledge, 2009. VAQUERO, Manuel de La Calle e HERNÁNDEZ, María García. "Ciudades históricas; patrimonio cultural y recurso turístico”. Ería, Madri, 1998, n. 47, pp. 249-66.

VINUESA, Miguel Ángel Trotiño. "Aranjuez: patrimonio cultural, recuperación urbana y turismo". Cuadernos de Turismo, Murcia, 2002, volume extraordinário, pp. 495-518.

WORLD TOURISM ORGANIZATION (WTO) e EUROPEAN TRAVEL COMISSION (ETC). City tourism and culture. The European experience. Bruxelas, 2005. 


\section{A inserção da variável ambiental no planejamento turístico: por uma abordagem estratégica}

Clara Carvalho de Lemos

Com o aumento dos padróes de vida e as facilidades de transporte, as pessoas viajam cada vez mais e exploram um número cada vez mais diversificado de destinos, o que vem causando um enorme impacto nas economias, no consumo, nas trocas comerciais, nos padrões de deslocamento e mobilidade, nas relações sociais e no espaço.

Em muitos lugares, o turismo tornou-se um importante setor econômico, em função de sua atraente capacidade de gerar impactos diretos e indiretos, resultados de grande variedade de despesas dos visitantes em transporte, alojamento, entretenimento, alimentos e bebidas, comércio etc. Muitos governos de todo o mundo, portanto, estimulam o turismo e as suas atividades de lazer associadas como importantes estruturas de suas economias.

Apesar de reconhecida a necessidade de se buscar formas de inserir a variável ambiental em ações de planejamento estratégico do turismo, a pesquisa sobre o tema ainda é limitada. Já existe 
alguma experiência e prática internacional no que diz respeito à abordagem estratégica dos impactos ambientais do turismo, em especial no âmbito de políticas, planos e programas. No Brasil, entretanto, essa discussão ainda é recente, dado que o gerenciamento de impactos acontece em momentos tardios; ou seja, o estímulo ao turismo precede o planejamento, e o poder público, geralmente, concentra esforços em minimizar os impactos que o aumento do fluxo turístico causa em áreas naturais, desconsiderando outras consequências inevitáveis que essa atividade pode trazer para uma região, como a pressão sobre o arranjo territorial, a pressão sobre os recursos naturais e as reservas de água, o aumento da produção de resíduos, efluentes etc.

Apesar de alguns curtos períodos de estagnação e crises econômicas, o turismo ainda vive um período de crescimento contínuo e significativo. Tendo em vista, portanto, a necessidade de pesquisa em abordagens estratégicas na gestão dos impactos negativos da atividade, este estudo apresenta e discute algumas experiências identificadas e oferece alguns subsídios e reflexões para o tratamento dessas questôes, especialmente no contexto brasileiro.

\section{A variável ambiental no contexto do planejamento turístico}

São vários os fatores que influenciam a ocorrência de impactos ambientais negativos de atividades turísticas e a intensidade e frequência com que eles ocorrem. Esses impactos devem variar, principalmente, de acordo com (Cohen, 1978; OMT, 2003; Simpson e Wall, 1999):

- A intensidade do uso turístico: o volume de visitantes, o tempo de permanência no local e a concentração da utilização turística em locais e épocas específicos determinam a intensidade do uso turístico. A alta intensidade 
de fluxo turístico poderá acarretar pressão sobre as áreas naturais e urbanas e os recursos a elas associados.

- Tipo de utilização ou de atividade turística: o tipo de atividade turística (atividades desenvolvidas e as facilidades requeridas) está diretamente relacionado aos impactos ocasionados. Algumas atividades são mais intensivas no uso de recursos naturais, emitem mais ruídos e resíduos e/ou demandam maior quantidade de facilidades (infraestrutura, suprimentos, mão de obra, matérias-primas etc.).

- Características da área de destino: os ambientes diferem em termos de fragilidade, sensibilidade e capacidade de recuperação. As características do meio ambiente, portanto, influenciam sua capacidade de absorver impactos. Algumas áreas são mais suscetíveis ao dano ambiental do que outras, e são as suas características naturais que devem condicionar sua capacidade de receber fluxos turísticos e infraestrutura associada.

- Gestão e contexto político: os impactos estão intimamente relacionados aos tipos de planejamento e estratégias de gestão associados à atividade turística. A maioria dos casos de impactos negativos da atividade ocorre em áreas em que há pouco controle, gerenciamento de má qualidade ou inexistente e um sistema legal falho.

Em um estudo realizado no Parque Nacional do Itatiaia, Serrano (1999) analisou o uso do local por turistas e visitantes e chamou a atenção para o fato de que o argumento do impacto turístico, que por vezes justifica a interdição de algum tipo de uso do local por visitantes, em geral, mascara a insuficiência ou a incompetência administrativa, pois os impactos inerentes da atividade turística em áreas naturais podem ser atenuados por uma 
série de medidas de controle e gestão. Isso confirma a ideia de que são as estratégias de gerenciamento e os instrumentos de gestão utilizados que devem influenciar de modo mais significativo os níveis de impacto ocasionados pela atividade turística. São as estratégias de gestão que permitem o controle dos outros fatores causadores de impacto.

Para isso, nas últimas décadas, vários instrumentos de gestão e planejamento foram desenvolvidos, com especial referência ao uso turístico de áreas naturais, no sentido de resolver os conflitos e impactos do turismo (Boyd e Butler, 1996).

A capacidade de carga ou suporte é um desses instrumentos de gestão, já amplamente aplicado em estratégias de controle de fluxos turísticos em áreas naturais, especialmente a partir da década de 1990. Este instrumento é o resultado de uma apropriação do conceito utilizado na gestão de pastagens para determinar o número de animais que podem ser mantidos em certa área de pasto. No turismo, sua adoção consiste no cálculo de um número máximo de visitas por dia que uma área natural pode suportar (Cifuentes, 1992).

Fazendo uma análise sobre estudos e experiências de capacidade de carga em distintas partes do mundo, Pires (2005) identificou vários enfoques de abordagem desse conceito. De maneira geral, a aplicação desse instrumento está relacionada ao estabelecimento de um número máximo de usuários ou atividades permitidas em certa área ou na determinação dos níveis de degradação ecológica que possam ser considerados aceitáveis.

As principais críticas referem-se ao fato de que estabelecer número de visitantes para áreas naturais é muito mais um conceito intuitivo do que científico e que a magnitude do impacto não é necessariamente condicionada pelo número de turistas. Wearing e Neil (2001) também são críticos desse método e garantem que a prática de limitar o número de visitantes é, muitas vezes, uma solução imprópria e simplista. 
Exemplo disso é o estudo sobre efeitos provocados pelos passeios de barco (observação e nado com golfinhos) em Northland, na Nova Zelândia. Constantine et al. (2003) afirmam que parece não existir uma relação direta entre a magnitude do impacto e o número de barcos e banhistas, mas sim com o tempo de exposição desses animais a esses encontros, resultando em impactos cumulativos significativos. Os autores sugerem, portanto, que é preferível que todos os barcos interajam com os golfinhos em um mesmo período delimitado a distribuí-los em um período mais extenso.

Outros sistemas de gerenciamento e manejo de visitantes baseados em condições sociais e ambientais desejáveis representam uma reformulação do conceito de capacidade de carga, de forma a compensar e/ou suprir algumas de suas limitações.

Lindberg et al. (1997) defendem o argumento de que o foco do manejo das visitas a áreas naturais deve ser "quais são as condições desejáveis”, em vez de simplesmente estabelecer números máximos de visitantes. É essa visão de gestão, baseada no desenho de indicadores, cenários e monitoramento, que caracteriza os sistemas de manejo como o Limits of Acceptable Change (LAC), o Visitor Impact Managment (VIM), o Visitor Experience Resource Protection (VERP), dentre outros.

Freixêdas-Vieira et al. (2000) mostram que esses métodos apresentam em comum o fato de se basearem em condições sociais e ambientais desejadas para o futuro, e, por meio do monitoramento da área, avalia-se se as ações de manejo estão produzindo os resultados esperados sem alterar outras características da experiência ou do ambiente.

Nota-se, portanto, uma evolução do manejo da visitação pública em áreas naturais, partindo do simples controle do número de pessoas, estabelecido pela capacidade de carga, a instrumentos que estabelecem padrões e condições ambientais de mudanças aceitáveis e o contínuo monitoramento dessas questôes. 
Identificados os impactos e suas causas, podem-se estabelecer estratégias de controle e redução de impactos, sejam elas a limitação do número de pessoas ou outras ações de manejo, como educação ambiental, mudanças nas regras para atividades desenvolvidas no interior da área, mudanças no traçado de trilhas, no zoneamento da área etc.

Existem ainda diversos mecanismos de planejamento e gerenciamento que costumam ser adotados no controle de fluxos turísticos em áreas naturais, como os sistemas de permissões e licenças de operação necessárias para o funcionamento de operadoras turísticas em determinadas áreas controladas; a aplicação de taxas de visitação, que tanto podem ser úteis para a manutenção e desenvolvimento da infraestrutura local como podem funcionar como reguladoras de demanda, reduzindo problemas de excesso de procura; e a definição de padrões de qualidade ambiental mínima.

Constata-se, porém, que, apesar de algumas diferenças de enfoque e metodologia, esses instrumentos têm em comum o fato de serem pouco aplicáveis a outras situações que não a visitação em áreas naturais protegidas. Pires (2005) já chamou atenção para isso ao afirmar que, quando se trata de considerar espaços de recreação e turismo não protegidos na forma de unidades de conservação, como praias, cidades, áreas rurais ou outros espaços com recursos naturais demandados para a mesma finalidade, esses modelos têm a sua aplicação altamente dificultada, senão inviabilizada.

Outro instrumento também conhecido e muito utilizado em vários países e com forte influência no desenvolvimento de atividades turísticas é o zoneamento. Sua principal interface com o turismo, mais uma vez, diz respeito fundamentalmente ao uso público de unidades de conservação.

Exemplo disso é o uso que se faz do zoneamento para o planejamento espacial da Grande Barreira de Corais, na Austrália, como forma de mediar conflitos de usos desse parque marinho de 
aproximadamente $345.000 \mathrm{~km}^{2}$. O zoneamento divide o local em áreas de acordo com seus possíveis usos, como as áreas de pesquisas, navegação, pesca, mergulho, turismo, proteção de habitats, zona de amortecimento, área de preservação etc. (Day, 2002).

Em outros casos, fora de áreas naturais protegidas, o zoneamento está geralmente associado ao planejamento territorial do solo mediante o estabelecimento de zonas com diferentes tipos e intensidades de uso. Essa abordagem se aproxima do modelo de "zoneamento do uso do solo urbano" citado em Ranieri et al. (2005), em que o seu resultado origina um mapa com identificação de zonas e suas respectivas indicações de usos permitidos e proibidos. Os autores destacam o fato de que essa abordagem está presente na maioria das definiçóes de zoneamento, apresentado como um instrumento com função de ordenamento territorial que tem o poder de intervir sobre o direito de propriedade e estabelecer limitações a esse direito.

Os autores constataram que no Brasil existe ampla gama de produtos (materializados na forma de mapas e relatórios a eles associados) aos quais foi atribuída a denominação de zoneamento ambiental ou qualquer outra semelhante, conforme o interesse da equipe ou instituição responsável por sua elaboração. Observando esses estudos, os autores concluíram que a maioria dos produtos de zoneamentos foi elaborada, normalmente, com boas intenções, mas desconsiderando a existência e a necessidade de articulação com os demais instrumentos da Política Nacional de Meio Ambiente: licenciamento ambiental, avaliação de impactos ambientais, padrões de qualidade, sistemas de informações ambientais etc.

A avaliação de impacto ambiental, outro instrumento amplamente utilizado em várias partes do mundo, também apresenta importante interface com o turismo, pois cada vez mais se reconhece a sua importância como parte de avaliações de propostas de desenvolvimento turístico (Hunter, 1995). 
Butler (1991 apud Hunter, 1995), contudo, já observava que, em muitas localidades, e por muitos anos, as avaliações de impacto de empreendimentos turísticos ocorriam, na maioria das vezes, de forma reativa, quando já haviam sido aprovados esses projetos.

Essa constatação não é exclusiva do setor de turismo e, como já afirmado, a realidade mostra que a avaliação de impacto ambiental nem sempre é capaz de garantir que as questóes ambientais sejam incorporadas na concepção e elaboração de projetos e empreendimentos.

Morgan e Onorio (2000) ainda chamam a atenção para o fato de que os impactos cumulativos do turismo devem ser considerados, o que, geralmente, não acontece mediante a avaliação de impacto ambiental de projetos, que considera apenas os impactos diretos. Assim, torna-se evidente a necessidade de uma avaliação das políticas governamentais de incentivo ao turismo antes da aprovação de projetos específicos para determinadas localidades.

Por outro lado, é muito comum, especialmente no setor do turismo, que os representantes da iniciativa privada defendam a autorregulação, feita por intermédio de códigos de conduta, esquemas de certificação e credenciamento e regulamentos próprios, como método preventivo de conflitos entre a atividade e as questôes ambientais.

Essa atitude ativa da indústria em relação aos seus conflitos ambientais é sempre a solução preferida pela própria indústria, em vez da submissão a regulamentações e outras medidas de controle por parte do Estado. A autorregulação, contudo, no que se refere a essas questóes ambientais, nem sempre foi bem-sucedida em outros setores, como na mineração e na agricultura (Wearing e Neil, 2001). É necessário cautela nesses casos, já que a atuação do Estado pode ser decisiva para evitar que o desenvolvimento turístico implique prejuízos significativos à qualidade ambiental local.

Nem sempre a ponderação dos fatores ambientais e sociais é compromisso explícito de políticas de incentivo a grandes inves- 
timentos, em que os fatores econômicos são mais considerados. Argumenta-se, portanto, que a inserção da variável ambiental no processo decisório estratégico é uma forma de dar um peso maior a essas questôes no jogo da decisão política.

No turismo, essa necessidade ganha força, pois, em muitos destinos turísticos, a explosão de investimentos em obras e empreendimentos de grande porte - como hotéis, resorts, estradas e aeroportos - é resultado de políticas de atração e incentivo do poder público, em nome da criação de empregos e da entrada de divisas. Além disso, muitas das consequências negativas do turismo são resultados de impactos induzidos e sinérgicos. A necessidade de avaliações estratégicas, portanto, é indiscutível.

Por outro lado, Swarbrooke (2000) também destaca que, muitas vezes, é difícil perceber o que pode ser alcançado com o planejamento por parte do Estado na área de turismo, considerando que o setor público não possui nem é capaz de controlar muitos dos elementos-chave do produto turístico e, por essa razão, o conceito de parceria e colaboração cresceu em popularidade nos últimos anos.

Ao discutir o papel das redes de colaboração no turismo, Hall (2008) também destaca seus resultados positivos em algumas partes do mundo - a Nova Zelândia se destaca, pois em dez anos estabeleceu grande número de redes de colaboração para o desenvolvimento de produtos e roteiros gastronômicos ligados ao enoturismo - e chama a atenção para o papel dos governos, que atuam como incentivadores do processo de criação das ações de colaboração em várias das iniciativas existentes. $\mathrm{Ou}$ seja, mesmo em destinos turísticos nos quais a iniciativa privada imprime um papel forte de atuação no campo do planejamento, os governos ainda encontram motivos para atuarem como mediadores e coordenadores do desenvolvimento turístico. Os frequentes impactos e conflitos gerados pelo turismo também reforçam essa necessidade. 
Além disso, Boyd e Butler (1996), ao analisarem os instrumentos de gestão mais utilizados para o controle turístico em áreas naturais, já assinalavam a necessidade da elaboração de diretrizes capazes de avaliar as oportunidades do turismo frente a outros possíveis usos dos recursos naturais, os quais levassem em consideração as necessidades das comunidades e a significância dos impactos ambientais e sociais do desenvolvimento turístico.

Da mesma forma, a Organização Mundial de Turismo (OMT, 2003) chama a atenção para a antecipação dos impactos do desenvolvimento como função essencial de um plano turístico e acentua que avaliar os impactos ambientais se tornou um padrão e, em muitos lugares, uma exigência do processo de planejamento.

Nesses casos, como destaca Dias, "o Estado, em todos os níveis, ainda é o único agente capaz de articular amplas forças da sociedade numa perspectiva de planejar um desenvolvimento identificado com a preservação do meio ambiente, socialmente justo e economicamente viável" (2003, p. 35).

Entende-se, portanto, que as iniciativas de gestão ambiental na atividade turística não podem estar restritas ao controle de fluxo em áreas naturais, a medidas compensatórias para os impactos causados pelo número excessivo de visitantes, ou à autorregulação por parte do setor, já que essas condiçōes têm origem e são resultados de questóes políticas e estratégicas que envolvem o planejamento.

Assim, o Estado tem importante papel a desempenhar, pois detém a responsabilidade total e coletiva de assegurar que os benefícios auferidos com o turismo, inclusive os financeiros, não sejam obtidos em detrimento das necessidades sociais, culturais e ambientais (Beni, 2003). Acredita-se, portanto, que uma abordagem mais estratégica para o planejamento ambiental do turismo seja necessária, no sentido de garantir a consideração de um espectro mais amplo de questôes no processo decisório. 


\section{Avaliação ambiental estratégica: aspectos conceituais e sua aplicação no turismo}

A avaliação de impactos ambientais traz em seu conceito a ideia de um processo sistemático que analisa de maneira prévia as consequências ambientais das ações de desenvolvimento. A ênfase, portanto, em comparação com outros mecanismos de proteção do ambiente e de avaliação em geral, é na prevenção e na dimensão temporal prévia. Desde então, a prática foi difundida de maneira considerável por todo o mundo. Atualmente, a avaliação de impacto ambiental é entendida, mas nem sempre rigorosamente aplicada, como um instrumento de apoio à tomada de decisão, que fornece uma análise sistemática das implicações ambientais de uma ação proposta e suas alternativas, antes que uma decisão seja tomada (Glasson et al., 1999).

Mais recentemente, o desafio de sua aplicação em níveis cada vez mais estratégicos, tendo como foco a variável ambiental, tem sido discutido com mais frequência na literatura, e a difusão da prática se mostra cada vez mais comum. Essa aplicação se coloca como um desafio em virtude da complexidade do ambiente de planejamento estratégico visto de uma perspectiva de avaliação. Nesses casos, é preciso lidar com o caráter multissetorial e amplo de muitos dos planos a serem avaliados, com uma gama mais complexa de impactos (indiretos, induzidos e cumulativos), bem como com a complexidade espacial e temporal da sua distribuição, com inúmeras conexões entre diferentes planos (horizontais e verticais) e os impactos que eles causam uns aos outros (Lee, 2006). Essas questões serão mais profundamente discutidas a seguir, à luz dos desenvolvimentos teóricos e práticos mais recentes acerca do tema.

A partir da década de 1980, a literatura especializada em avaliação de impacto ambiental passou a dedicar bastante atenção à necessidade de se fazer uma clara distinção entre a avaliação de 
impacto ambiental de projetos e aquela aplicada para avaliar ações mais estratégicas de tomada de decisão (Fischer, 2007).

Desde 1969, com a aprovação do National Environmental Policy Act (Nepa), os Estados Unidos já exigiam uma avaliação dos efeitos ambientais de propostas de lei ou outras ações do governo federal que pudessem afetar significativamente o meio ambiente. Apesar disso, foi só a partir da década de 1980 que o termo "avaliação ambiental estratégica" se propagou com o intuito de fazer referência a avaliações de ações mais estratégicas, como políticas, planos e programas.

Bina (2007) argumenta que, desde sua concepção inicial, havia intenção de aplicar a avaliação de impacto ambiental a todos os níveis de planejamento, desde ações mais estratégicas até empreendimentos e projetos mais pontuais. O próprio Nepa, nos Estados Unidos, se referia a "ações federais", sujeitas à avaliação de impacto ambiental, sem fazer distinção entre projetos e ações mais estratégicas, como políticas, planos e programas. Progressivamente, na prática, as avaliações de políticas, planos e programas - nos Estados Unidos denominadas de "avaliações ambientais programáticas" - foram se diferenciando, em termos de escalas geográficas e métodos utilizados, dos estudos de impacto ambiental de projetos. Resta entender que a diferença entre ambas - avaliação de empreendimentos e avaliação de ações estratégicas - se dá muitos menos na questão conceitual e muito mais na prática (abordagens, procedimentos, métodos e técnicas).

De maneira geral, a avaliação ambiental estratégica (AAE) é entendida como um processo sistemático (Fischer, 2007), que envolve a aplicação de diferentes métodos e técnicas para compreensão e consideração prévias de questôes ambientais em determinado contexto político e institucional de planejamento. Seguindo padróes mínimos de procedimentos (Jessel, 2005) e uma série de etapas específicas (Jones et al., 2005), o processo deve culminar em diferentes graus de resultados diretos e indiretos, tais como influência direta sobre 
a qualidade ambiental e sobre as decisões e atitudes em relação ao meio ambiente, conscientização e mudanças nos arranjos institucionais e departamentais e no conteúdo de políticas, planos e programas (Retief, 2007). Além disso, reconhece-se cada vez mais o papel da AAE no fortalecimento de processos estratégicos e da governança, bem como na construção de um ambiente de confiança e corresponsabilidade em decisóes estratégicas (Fischer, 2007).

Verheem e Tonk (2000) apresentaram a avaliação ambiental estratégica como um instrumento de "um conceito e múltiplas formas", ou seja, um instrumento que permite grande variedade de processos diferentes, com o intuito de alcançar os mesmos objetivos. Os autores acreditam que os procedimentos de $\mathrm{AAE}$ não podem funcionar como uma camisa de força, em que o planejamento deve ser forçado a se adequar.

Verificou-se alguma experiência e prática internacional no campo da AAE para políticas, planos e programas de turismo, além de considerável quantidade de estudos e pesquisas em outros setores e campos de atuação. Já existe também pesquisa considerável no que se refere a alguns princípios e melhores práticas de AAE; porém, o desafio de adaptá-los a realidades políticas e institucionais tão diversas ainda persiste (Lemos, 2007).

D'Ieteren (2006) destaca que as etapas da AAE deverão se adaptar à forma e estrutura em que se dá o processo de planejamento do turismo no país (as etapas seguidas, os grupos de interesse relacionados, os canais de participação pública já existentes, as informações ambientais disponíveis etc.). Segundo o autor, o processo de AAE também vai depender de como as questôes ambientais são levadas em consideração no sistema de planejamento em caso.

Destacaram-se, em outra ocasião (Lemos, 2007), alguns desafios para a inserção da AAE na gestão do turismo no Brasil, especialmente a necessidade de fortalecer ações de integração interinstitucional; identificar interfaces com outros instrumentos da 
política ambiental; adaptar a AAE aos processos de planejamento e estruturas institucionais já existentes; integrar ações de planejamento com estratégias de educação ambiental; facilitar a abertura e a transparência do processo de planejamento, fortalecendo e aumentando os canais de participação pública no processo decisório; além de criar um sistema de referência ambiental estratégico, que possa nortear e condicionar o desenvolvimento turístico no país.

O planejamento para o turismo ocorre em uma diversidade de formas (desenvolvimento, infraestrutura, promoção e comercialização), estruturas (diversas organizações governamentais e não governamentais), escalas (internacional, nacional, regional, local e setorial) e momentos (diferentes escalas temporais para desenvolvimento, execução e avaliação). No entanto, esse planejamento raramente é exclusivamente dedicado ao turismo em si. Em vez disso, o planejamento para o turismo tende a ser um amálgama de considerações e avaliaçóes relacionadas a questóes econômicas, sociais e ambientais, o que reflete a diversidade dos fatores que influenciam o desenvolvimento do turismo (Hall e Page, 2006).

Apesar de já existir alguma prática relacionada a tentativas de inserir a AAE no setor de turismo no Brasil, pode-se afirmar que se trata muito mais de iniciativas experimentais e que a maior reflexão acerca do papel que esse instrumento pode vir a desempenhar no planejamento para o turismo ainda se faz necessária, tendo em vista a diversidade de variáveis que influenciam e condicionam o desenvolvimento dessa atividade.

\section{Turismo e AAE: uma análise da prática internacional}

Experiências chamadas de AAE têm ocorrido no âmbito do planejamento do turismo desde os anos 1990. A prática, porém, só se tornou mais difundida após a introdução da diretiva europeia (2001/42/CE), que trata da avaliação ambiental de planos de programas. Ela estabelece que todos os planos e programas de 
turismo elaborados pelas autoridades nacionais, regionais e locais que são suscetíveis de ter efeitos significativos no ambiente e são exigidos por disposiçôes legislativas, regulamentares ou administrativas, devem ser sujeitos à AAE. O setor do turismo na Europa é considerado o maior e mais bem estabelecido do mundo (UNWTO, 2010), e sua relevância em termos de potencial impacto no meio ambiente é reconhecido quando a diretiva inclui o turismo como um dos setores-chave que devem ser objeto de avaliação estratégica.

Embora a diretiva (2001/42/CE) tenha tido maior impacto sobre os estados membros da União Europeia, outros países também começaram, especialmente na última década, a utilizar o instrumento com maior frequência. Além disso, como o estímulo ao desenvolvimento do turismo também está frequentemente associado a estratégias de redução da pobreza e geração de empregos não qualificados, muitos países em desenvolvimento e economias emergentes incentivam o turismo como estratégia de desenvolvimento no contexto dos programas de investimento de agências bilaterais e multilaterais. $\mathrm{O}$ uso da AAE nesse contexto cresce de maneira significativa e é considerado extremamente relevante, pois muitos países em desenvolvimento dependem fortemente de atividades econômicas primárias, como agricultura, turismo e mineração, que são particularmente vulneráveis à degradação ambiental (Retief et al., 2008).

$\mathrm{O}$ uso da AAE para o planejamento turístico está aumentando em função das exigências legais que muitos países já possuem e, de maneira geral, em virtude dos apelos para que planejadores e tomadores de decisão olhem de forma mais estratégica para os efeitos negativos que o desenvolvimento turístico pode causar sobre o meio ambiente.

Tendo como foco, portanto, os planos e programas setoriais de turismo, uma pesquisa foi realizada a fim de obter um retrato da extensão da prática da $\mathrm{AAE}$ no planejamento turístico. Esta 
busca foi realizada por meio de pesquisa bibliográfica, pesquisas em sites de busca e contato pessoal com profissionais e especialistas envolvidos com a prática da $\mathrm{AAE}$. $\mathrm{O}$ quadro 1 relaciona alguns dos principais casos identificados no Brasil e no mundo, disponibilizados nos relatórios ambientais resultantes das avaliações. Além disso, três casos foram mencionados na literatura, dos quais, no entanto, não foi possível obter informações completas e necessárias: 1) a AAE das praias de Tofo, Barra, Rocha e Tofinho, em Moçambique (Dalal-Clayton e Sadler, 2005); 2) a AAE da vila turística de El Calafate, na Argentina (Lestingi, 2005); e 3) a AAE da política nacional de turismo da República Tcheca (Dalal-Clayton e Sadler, 2005).

Quadro 1: relação dos casos de AAE aplicados a planos de turismo.

\begin{tabular}{ll}
\hline País & Casos de AAE/Turismo \\
\hline Belarus & AAE do programa nacional de desenvolvimento do turismo. \\
\hline Bolívia & $\begin{array}{l}\text { Avaliação ambiental programática das atividades e facilidades do turismo } \\
\text { de Cochabamba. }\end{array}$ \\
\hline & AAE do polo Costa Norte. \\
\cline { 2 - 2 } & $\begin{array}{l}\text { Avaliação ambiental programática do Programa de Desenvolvimento do } \\
\text { Turismo (Prodetur) - Sul. }\end{array}$ \\
\cline { 2 - 2 } Brasil & $\begin{array}{l}\text { AAE nos polos turísticos do estado do Rio de Janeiro (polo Litoral e polo } \\
\text { Serra). }\end{array}$ \\
\cline { 2 - 2 }
\end{tabular}

AAE do Prodetur nacional no estado do Mato Grosso do Sul.

\begin{tabular}{ll}
\hline China & AAE do desenvolvimento do turismo na província de Guizhou. \\
\hline República & AAE do Programa Setorial Operacional da Indústria do Turismo e do \\
Tcheca & Spa. \\
\hline Equador & AAE do turismo costeiro. \\
\hline Inglaterra & $\begin{array}{l}\text { Avaliação de sustentabilidade da estratégia espacial regional do turismo } \\
\text { do Sudeste da Inglaterra. }\end{array}$ \\
\hline
\end{tabular}




\begin{tabular}{|c|c|}
\hline Ilhas Fiji & AAE do plano de desenvolvimento do turismo das Ilhas Fiji. \\
\hline Honduras & AAE da estratégia de turismo. \\
\hline \multirow{5}{*}{ Itália } & AAE do programa de desenvolvimento do turismo de Orobie Bergamasche. \\
\hline & AAE do plano estratégico regional de turismo do Piemonte. \\
\hline & AAE do programa de desenvolvimento do turismo de Riviera del Garda. \\
\hline & AAE do programa de desenvolvimento do turismo de Adamello. \\
\hline & AAE da vila dos esportes de Muggiò. \\
\hline México & AAE do setor do turismo. \\
\hline Portugal & AAE do plano de pormenor de Cova do Lago. \\
\hline \multirow{3}{*}{ Escócia } & AAE do plano corporativo Visit Scotland 2007-10. \\
\hline & AAE da estratégia de turismo e plano de ação de East Dunbartonshire. \\
\hline & AAE do plano de ação do turismo de Lanarkshire. \\
\hline \multirow{2}{*}{ Espanha } & AAE do plano do turismo sustentável da Andalucía 2008-11. \\
\hline & AAE do plano especial do complexo turístico de Umbría de La Serrata. \\
\hline Tanzânia & $\begin{array}{l}\text { AAE para o desenvolvimento do turismo no circuito turístico do Norte } \\
\text { da Tanzânia. }\end{array}$ \\
\hline Turquia & AAE piloto do plano de desenvolvimento do turismo de Oymapýnar. \\
\hline País de & AAE da estratégia de turismo da Costa Galesa (Welsh Coastal Tourism \\
\hline Gales & Strategy). \\
\hline
\end{tabular}

No Brasil, as experiências de AAE para o turismo estão ocorrendo no âmbito do Prodetur. Outros polos - além dos apresentados no quadro 1 - também foram requisitados a apresentar seus estudos de avaliação estratégica, aplicados aos Planos de Desenvolvimento Integrados do Turismo Sustentável (PDITS) e de acordo com o Manual de planejamento e gestão socioambiental do programa (Ministério do Turismo, 2009). Boa parte desses relatórios, no entanto, não está disponível para consulta.

É importante destacar também que o turismo é muitas vezes um "elemento" de muitos planos integrados ou mesmo setoriais, e 
o grau de sua relevância, com frequência, depende sobremaneira da sua importância e de seu impacto na economia em foco. Em muitas AAEs aplicadas a planos territoriais, espaciais ou até mesmo de transportes, o turismo também vem sendo avaliado frente a outras possíveis opções de desenvolvimento.

\section{Subsídios para a AAE aplicada ao turismo}

A análise de experiências de aplicação da AAE para planos de turismo no Brasil e no mundo pode oferecer importantes subsídios em termos de procedimentos, abordagens e metodologias adotados, dos resultados possíveis de serem alcançados e dos principais desafios e limitações que envolvem a prática. Considerando os relatórios identificados, analisados e discutidos (Lemos et al., 2012), apresenta-se aqui uma síntese dos principais subsídios relacionados à aplicação da AAE para o setor de turismo. Esses subsídios sintetizam os desafios e as diretrizes gerais a serem observadas num sistema de elaboração de ações e procedimentos em que se pretende aplicar a AAE para o planejamento do turismo, em especial no que se refere às bases para aplicação da AAE, ao cenário institucional, às questões-chave e ao escopo dos planos e sua relação com o instrumento.

\section{Bases para a aplicação da $A A E$}

A maioria das experiências de AAE para o turismo ocorrem em situações muito pontuais e isoladas, já que boa parte dos planos de turismo não é, necessariamente, elaborada de maneira regular ou sob bases formais. A aplicação da AAE ao planejamento do turismo geralmente ocorre quando os planos e programas a serem avaliados possuem certo grau de formalidade e de base legal, ou quando são requeridos por instituições multilaterais de investimento como parte do processo de aprovação de empréstimos de recursos. 
O estabelecimento de requisitos legais e formais que exijam ou estimulem a aplicação da AAE, portanto, é o principal meio para garantir a incorporação do instrumento e da variável ambiental no planejamento do turismo.

Requisitos legais são frequentemente vistos como limitadores do processo, pois estabelecem prescriçōes e fórmulas que nem sempre são consenso. Apesar disso, são essas regras e diretrizes que estão hoje oferecendo oportunidade para que profissionais e planejadores aprendam, experimentem a prática a partir de referências comuns e entendam a aplicação e as possibilidades do instrumento.

Apesar de necessária e importante, a avaliação do desenvolvimento do turismo não deve ser restrita às oportunidades oferecidas pelos planos integrados (como é o caso dos planos territoriais). Requisitos e diretrizes devem estimular a adoção voluntária da AAE como rotina nas instituições setoriais, especialmente aquelas com baixo nível de formalidade de suas ações.

\section{Cenário institucional}

O turismo é um setor fragmentado e, por isso, é preciso que se identifique todo o quadro institucional (público, privado e terceiro setor) relacionado ao planejamento e à execução das ações desse setor.

A AAE pode ser um meio para estimular a criação de parcerias locais, regionais e nacionais que incorporem organizaçōes da iniciativa privada e da sociedade na busca por objetivos comuns no setor e pelo compartilhamento de responsabilidades.

\section{Impacto da AAE sobre o conteúdo dos planos analisados}

Deve-se buscar a integração das ações de planejamento setorial com outros planos integrados (territoriais, espaciais etc.). As 
estratégias setoriais devem alimentar outros planos integrados e serem influenciadas por estes também.

Além de incentivar a incorporação de valores e objetivos ambientais e de sustentabilidade, a AAE deve oferecer oportunidades reais de discutir opçôes, alternativas e diferentes cursos de ação. Esse parece ser o elo mais fraco entre os relatórios de AAE e os planos. Esses relatórios têm dispensado muito mais atenção em identificar objetivos de sustentabilidade e medidas mitigadoras do que em oferecer opções e alternativas que possam causar impactos significativos nos cursos de ação dos planos analisados.

As principais funçôes que uma AAE deve ser capaz de influenciar no setor do turismo são: objetivos e características gerais do turismo, gestão da oferta e gestão da demanda.

Além disso, o quadro 2 oferece uma estrutura com questões setoriais a serem tratadas em procedimentos de AAE, no sentido de auxiliar o foco nas questões que realmente podem fazer a diferença na busca por alternativas e opções de desenvolvimento do turismo.

Quadro 2: questões setoriais a serem tratadas na AAE para planejamento do turismo.

\section{Foco do planejamento Questóes a serem tratadas na AAE}

Objetivos e características gerais

Regras e orientações gerais para o desenvolvimento do turismo.

O papel do turismo no contexto geral.

Valores e visões (o papel do turismo na $\mathrm{O}$ que se pretende alcançar em termos de economia, sua relação com outros setores, a relação entre governos, iniciativa privada e terceiro setor). turismo e metas ambientais?

Estratégia geral, macro-objetivos e metas.

Quais os valores e objetivos de sustentabilidade associados? 


\title{
Oferta
}

Identificação e desenvolvimento de seg- Quais os padrões de qualidade ambienmentos, modalidades e produtos a serem tal que se pretende manter ou alcançar estimulados. e quais são as vantagens e desvantagens Facilitação e promoção de investimentos ambientais das diferentes modalidades (estratégias de mobilidade, comercializa- e segmentos de turismo? Qual o grau de ção, infraestrutura, facilitação do desen- compatibilidade desses segmentos com os volvimento). objetivos de sustentabilidade almejados?

Padrões de desenvolvimento, característi- Quais os critérios para definição de árecas e modelos espaciais (volume, intensi- as prioritárias para o desenvolvimento do dade, escala e a distribuição espacial). turismo? Quais são as áreas que precisam Critérios locacionais e zoneamento. ser protegidas para manter ou atingir as Características e regras de construção ou condições ambientais desejadas? operação de produtos, equipamentos e infraestrutura. Investidores e setor privado - regras gerais, origem e perfil.

\section{Demanda}

Qual é o grau de desenvolvimento do turismo que a área pode suportar, a fim de alcançar ou manter as condições ambientais desejadas?

Níveis de sazonalidade: estadias curtas e

Estímulo ao crescimento do turismo.

Metas de crescimento.

Promoção, comercialização e marketing Identificação de mercados (composição e características da demanda). mais frequentes versus estadias longas e menos frequentes.

Quais os perfis de turistas que se busca atrair? Qual a relação desses perfis com os objetivos de sustentabilidade (seus impactos sobre os hábitos de consumo, os padrões de mobilidade, as características culturais)?

Identificação das características, perfil e origem dos turistas.

\section{Considerações finais}

\author{
A aplicação do instrumento AAE tem sido frequente- \\ mente defendida por estar associada a uma série de benefícios \\ relacionados à incorporação da variável ambiental no planeja- \\ mento e na tomada de decisão estratégicos. No setor do turis-
}


mo, a aplicação da AAE como instrumento de auxílio ao planejamento setorial ainda ocorre de maneira pouco significativa quando comparada a outros setores, como transporte, uso do solo ou energia. Apesar disso, a prática é crescente, especialmente no Brasil, onde as agências multilaterais de investimento requerem relatórios que prestem contas acerca da consideração de questôes ambientais no processo decisório de investimentos para o turismo.

O que algumas pesquisas mais recentes demonstram é que os benefícios da aplicação da AAE não se apresentam de maneira uniforme e recorrente. Além disso, as próprias expectativas que se colocam sobre o instrumento são bastante variadas. No setor do turismo, essa constatação também não é diferente.

Os subsídios propostos aqui sintetizam as principais recomendações para aplicação da AAE no setor do turismo, especialmente as questões relacionadas às bases para sua aplicação, ou seja, os requisitos legais e o sistema de condiçôes, exigências e diretrizes que irão influenciar o alcance e a abrangência dessa aplicação para o setor do turismo. Sintetizam também o cenário institucional, ou seja, as relações entre os atores (público, privado e terceiro setor), os instrumentos e as instituições e a maneira como essa integração ocorre na realidade. Por fim, reúnem as questôes-chave e o escopo dos planos que tratam do planejamento do turismo, ou seja, o grau de abrangência desses planos, as principais questóes com as quais a AAE deverá lidar, as oportunidades de influenciar diferentes opções e cursos de ação, a integração com outros planos relacionados, a sua posição em relação ao restante do sistema e o seu papel frente às diferentes escalas de planejamento. 


\section{Referências}

BENI, Mário Carlos. "A política de turismo”. In TRIGO, Luiz Gonzaga Godoi (org.). Turismo. Como aprender, como ensinar. 3 ed. São Paulo: Senac, 2003, v. 1, pp. 177-202.

BINA, Olivia. "A critical review of the dominant lines of argumentation on the need for strategic environmental assessment". Environmental Impact Assessment Review, Gattikon, Suíça, out. 2007, v. 27, n. 7, pp. 585- 606.

BOYD, Stephen W. e BUTLER, Richard W. "Managing ecotourism: an opportunity spectrum approach". Tourism Management, Londres, dez. 1996, v. 17, n. 8 , pp. 557-66.

BUTLER, Richard W. "Tourism, environment, and sustainable development". Environmental Conservation, Cambridge, 1997, v. 18, n. 3, pp. 201-9.

CIFUENTES, Miguel A. "Determinación de capacidad de carga turística en áreas protegidas". In CATIE. Programa de manejo integrado de recursos naturales. Série técnica. Informe Técnico n. 194, 1992, 28 p.

COHEN, Erik. "The Impact of tourism on the physical environment". Annals of Tourism Research, Nova York, 1978, v. 5, n. 2, pp. 215-37.

CONSTANTINE, Rochelle et al. "Effects of tourism on behavioural ecology of bottlenose dolphins of northeastern New Zealand". DOC Science Internal Series, Wellington, dez. 2003, n. 153.

DALAL-CLAYTON, Barry e SADLER, Barry. Strategic environmental assessment: $A$ sourcebook and reference guide to international experience. Londres: Earthscan/ OECD/ UNEP/ IIED, 2005, 504 p.

DAY, John C. "Zoning-lessons from the Great Barrier Reef Marine Park". Ocean $\&$ Coastal Management, Barking, 2002, v. 45, n. 2-3, pp. 139-56.

DIAS, Reinaldo. Planejamento do turismo: politica e desenvolvimento do turismo no Brasil. São Paulo: Atlas, 2003.

D'IETEREN, E. "Integrer l'environnement dans les processus de developpement touristique: quelle contribution de l'evaluation environnementale strategique a la valorization touristique des territoires?". Anais do Colloque international: Developpement Territorial et Touri stique Durable. Bogotá: Universidad Libre de Bruselas/ Universidad Externado de Colombia/ Universidad del Atlantico, 2006, pp. 1-20.

FISCHER, Thomas B. Theory and practice of strategic environmental assessment: towards a more systematic approach. Reino Unido/ Estados Unidos da América: Earthscan, 2007, 218 p.

FREIXÊDAS-VIEIRA, Valéria Maradei et al. "Impactos do uso público: um guia de campo para utilização do método". Anais do II Congresso Brasileiro de 
Unidades de Conservação. Campo Grande: Rede Nacional de Pró-Unidades de Conservação, 2000, pp. 296-305.

GLASSON, John et al. "Introduction to environmental impact assessment: principles and procedures". Process, practice and prospects. 2 ed. Londres I Filadélfia: UCL Press, 1999, 496 p.

HALL, Colin Michael. Tourism planning: policies, processes and relationships. 2 ed. Londres: Pearson, 2008, 320 p.

_ e PAGE, Stephen. "The geography of tourism and recreation”. Environment, place and space. 3 ed. Londres / Nova York: Routledge, 2006, 456 p.

HUNTER, C. "Environmental impact assessment and tourism development". In HUNTER, C. e GREEN, H. Tourism and the environment: a sustainable relationship? Londres: Routledge, 1995, pp. 121-68.

JESSEL, Beate. "Methodological Approaches to SEA within the decision-making process". In SCHMIDT, Michael et al. (orgs.). Implementing strategic environmental assessment. Berlim: 2005, pp. 365-83.

JONES, Carys et al. Strategic environmental assessment and land use planning: an international evaluation. Londres: Earthscan, 2005, 320 p.

LEE, Norman. "Bridging the gap between theory and practice in integrated assessment". Environmental Impact Assessment Review, Gettikon, Suiça, jan. 2006, v. 26, n. 1, pp. 57-78.

LEMOS, Clara Carvalho. Avaliação ambiental estratégica como instrumento de planejamento do turismo (dissertação). USP, 2007.

_ et al. "Strategic environmental assessment in tourism planning: extent of application and quality of documentation". Environmental Impact Assessment Review, Gattikon, Suíça, jul. 2002, v. 35, pp. 1-10.

LESTINGI Patricio. "Una herramienta necesaria para la planificación de la ciudad”. Evaluación ambiental estratégica: Plan Estratégico Buenos Aires 2010. Buenos Aires: Gobierno de la Ciudad de Buenos Aires, 2005.

LINDBERG, Kreg et al. "Rethinking carrying capacity". Annals of Tourism Research, Nova York, 1997, v. 24, n. 2, pp. 461-5.

MORGAN, R. K. e ONORIO, K. R. "SEA of the Neiafu master plan, VaVa'u, Tonga”. In PARTIDÁRIO, M. R. e CLARK, R. (orgs.). Perspectives on strategic environmental assessment. Boca Raton: Lewis, 2000, pp. 197-213.

ORGANIZAÇÃO MUNDIAL DOTURISMO (OMT). Turismo internacional: uma perspectiva global. Trad. Roberto Cataldo Costa. 2 ed. Porto Alegre: Bookman, 2003, $254 \mathrm{p}$.

PIRES, Paulo Santos. "'Capacidade de carga' como paradigma de gestão dos impactos da recreação e do turismo em áreas naturais". Turismo em Análise, São Paulo, mai. 2005, v. 16, n. 1, pp. 5-28. 
RANIERI, Victor E. L. et al. "O zoneamento ambiental como instrumento de política e gestão ambiental”. In ESPÍNDOLA, E. V. G. e WENDLAND, E. (orgs.). PPGSEA: trajetórias e perspectivas de um curso multidisciplinar. São Carlos: RiMa, 2005, pp. 109-36.

RETIEF, Francois. "A performance evaluation of strategic environmental assessment (SEA) processes within the South African context". Environmental Impact Assessment Review, Gattikon, Suíça, jan. 2007, v. 27, n. 1, pp. 84-100.

_ et al. "The emperor's new clothes - reflections on strategic environmental assessment (SEA) practice in South Africa”. Environmental Impact Assessment Review, Gettikon, Suíça, out. 2008, v. 28, n. 7, pp. 504-14.

SERRANO, Célia Maria Toledo. "A vida e os parques: proteção ambiental, turismo e conflitos de legitimidade em unidades de conservação". In e BRUHNS, Heloisa Turini (orgs.). Viagens à natureza: turismo, cultura e ambiente. 5 ed. Campinas: Papirus, 1999, 150 p.

SIMPSON, Patty e WALL, Geoffrey. "Consequences of resort development: a comparative study". Tourism Management, Londres, 1999, v. 20, n. 3, pp. 283-96.

SWARBROOKE, John. Turismo sustentável: conceitos e impacto ambiental. Trad. Margarete Dias Pulido. São Paulo: Aleph, 2000, v. 1, 160 p.

UNITED NATIONS WORLD TOURISM ORGANIZATION (UNWTO). Tourism highlights, 2010. Disponível em http://www.unwto.org/facts/eng/ highlights.htm. Acesso em 17 nov. 2010.

VERHEEM, R. A. A. e TONK, J. A. M. N. "Strategic environmental assessment: one concept, multiple forms". Impact Assessment and Project Appraisal, Guildford, Surrey, set. 2000, v. 18, n. 3, pp. 177-82.

WEARING, Stephen e NEIL, John. Ecoturismo: impactos, potencialidades e possibilidades. Barueri: Manole, 2001, 256 p. 


\section{Turismo solidário: em busca de um conceito}

Rafael Ângelo Fortunato

O turismo é um fenômeno global com repercussões locais no qual é possível reconhecer diversas dimensóes. Tal fato o aproxima das abordagens científicas que buscam inspirações nas ideias relacionadas à complexidade e à transdisciplinaridade (Gaxiola, 2010; Ramírez, 2010).

A complexidade pode ser entendida como as relações e as sinergias entre as partes que compõem um fenômeno a ser analisado (Morin, 2005) e a transdisciplinaridade, por tudo que faz parte das disciplinas e está entre e além delas (Nicolescu, 1999).

Assim, quando existe a pretensão de se construir um conceito sobre um fenômeno turístico, como no caso deste capítulo, torna-se importante buscar a "essência" dele e reconhecer suas diferentes dimensões para que a referida complexidade possa ser constatada, analisada e dar sustentação para ações de caráter transdisciplinar.

Para isso, escolhi trabalhar com a fenomenologia como método de pesquisa e inspiração filosófica, a fim de analisar os casos ocorridos em pesquisas empíricas no campo do turismo solidário. A fenomenologia permite ir além das percepções superficiais sobre 
determinada atividade ou fenômeno (Husserl, 2008) e é conhecida por colocar os conhecimentos prévios em segundo plano no momento em que descreve as situações ocorridas no campo de pesquisa.

A busca de um conceito baseado na fenomenologia como método é inovadora e importante para as análises realizadas no campo do turismo, pois "a utilização do método fenomenológico possibilita progredir na discussão para a configuração de uma epistemologia aplicada ao turismo" (Panosso, 2005, p. 21).

O meu contato como pesquisador com ideias relacionadas ao turismo solidário ocorreu em 2008, quando iniciei meu doutoramento na Universidade do Estado do Rio de Janeiro (UERJ). Em 2011, defendi a tese Turismo solidário e a redescrição social no Vale do Jequitinhonha ( $M G)$.

Depois de seis anos de estudos empíricos e revisões bibliográficas, constatei que o termo é utilizado com grande frequência no mercado turístico, mas pouco discutido no meio acadêmico (Fortunato, 2011). No entanto, o turismo solidário é composto por uma gama de elementos novos - como trabalho voluntário associado ao turismo, hospedagem domiciliar e comunitária, criação de vínculos para promoção do turismo, encontros intersubjetivos com possibilidade de aumento no grau de intimidade (Fortunato, 2013) -, o que justifica esforços para elaborar propostas de conceituação do fenômeno.

Vale ressaltar que a construção de um conceito é importante na medida em que sinaliza novas reflexôes sobre o turismo e contribui para a sistematização das análises, criando e idealizando novas realidades.

Nessa busca pela conceituação do turismo solidário, encontrei inspiração em Bachelard, para quem "a conceitualização científica precisa de uma série de conceitos em vias de aperfeiçoamento para chegar a dinâmica que pretendemos, para formar um eixo de pensamentos inventivos" (1996, p. 76). 
É importante esclarecer que o conceito não é neutro, mas carregado das ideologias e percepçôes do pesquisador proponente. Trata-se, portanto, mais de uma construção do que de um retrato fiel da realidade; ou seja, lido com a perspectiva de que "a ciência constrói seus objetos, que nunca ela os encontra pronto” (1996, p. 77).

Trabalho também com as perspectivas apontadas por Rorty, para quem a realidade resiste às possíveis descrições que se possam fazer sobre ela. Rorty destaca ainda que "o que importa é nossa capacidade de falar com outras pessoas sobre o que nos parece verdade, e não sobre o que de fato é verdade" (2007, p. 292).

Para iniciar tal trajetória em busca de uma conceituação do turismo solidário, considero importante pontuar que: primeiro, este artigo apresenta autores que permeiam o turismo solidário, de acordo com uma escolha feita por mim, mas não pretende aprofundar-se em suas obras; segundo, trabalho com a premissa de que o turismo solidário tem como pretensão ser uma categoria de análise ampla do campo do turismo, em vez de uma modalidade de turismo, como o turismo rural; terceiro, o turismo solidário aproxima-se das ideias relativas ao turismo sustentável e ao turismo comunitário e, de uma forma bastante genérica, considero que o turismo sustentável, apesar de considerar questôes referentes às relações sociais e interpessoais, tem dado uma ênfase maior nas questões ambientais relacionadas à preservação e conservação da natureza enquanto o turismo comunitário enfatiza a ideia utópica de comunidade; quarto, no turismo solidário trabalha-se com a ideia de que qualquer preocupação com o ambiente natural tem como elementos estruturais as relaçóes interpessoais, e que a solidariedade antecede a formação de qualquer tipo de comunidade. Pensar em comunidades e sustentabilidade, portanto, envolve necessariamente o olhar proposto pela noção de solidariedade.

É importante esclarecer, também, que o objetivo não é hierarquizar, estabelecer um nível de importância para cada abordagem ou conceito, pois, na perspectiva da complexidade, tenta-se eliminar 
as armadilhas do reducionismo. Procuro, portanto, lançar questões para aquecer o debate sobre as potencialidades de o turismo promover transformações sociais por meio de uma reflexão crítica sobre as relaçôes interpessoais permeadas pela solidariedade.

Este artigo apresenta, no primeiro tópico, considerações sobre a solidariedade. Em seguida, o foco está na tentativa de entender como o turismo solidário aparece em sites pelo mundo, de realizar uma espécie de estado da arte do turismo solidário. No terceiro tópico, com base na fenomenologia e nos seis anos de pesquisa sobre o fenômeno, busco construir um conceito abrangente que evidencie a complexidade do fenômeno turístico quando relacionado à temática da solidariedade. Por último, apresento casos de turismo solidário inspirados no conceito construído e disseminado por meio da Rede Brasilidade Solidária.

\section{Breves consideraçóes sobre a solidariedade}

Primeiro, torna-se necessário deixar claro que solidariedade não significa simplesmente assistencialismo ou caridade, como frequentemente é apresentada no senso comum. A solidariedade pode ser entendida como uma forma de se estabelecer relações interpessoais baseada no reconhecimento recíproco, no respeito às diferenças, na horizontalidade no campo do saber e na máxima de tentar evitar o sofrimento alheio.

Por outro lado, em alguns casos, a solidariedade pode ser vivida apenas entre iguais. Durkheim (1999), por exemplo, apresenta a solidariedade mecânica vivida entre iguais, como no seio de um grupo religioso ou político, e a solidariedade orgânica, responsável por manter a sociedade por meio da troca de serviços e produtos. Nesse caso, parte-se da ideia de que existe certa complementaridade e reciprocidade entre os sujeitos para manutenção e sustentação da vida em sociedade. 
Abordagens relacionadas à solidariedade apresentam um contraponto em relação ao modelo de exclusão social, à incapacidade de se colocar no lugar do outro e ao problema da degradação ambiental.

Vale ressaltar que a preservação e a conservação ambientais, quando não consideram a questão da solidariedade, tornam-se "opressoras", na medida em que se apropriam da natureza para obtenção de benefícios individuais, tornando-a mais um recurso a ser comercializado no mercado.

Do mesmo modo, a economia, isto é, a "administração da casa", sem uma consideração pelo sofrimento de seus habitantes produz violência e injustiça social e torna a possibilidade da formação da comunidade, ou seja, a busca pelo bem comum, cada vez mais difícil.

Na visão de Buber (2001), em muitos casos, os vínculos interpessoais são pautados em uma relação do tipo "eu-isso", na qual um indivíduo se vê diante de outro indivíduo e o percebe como um objeto, não havendo uma relação do tipo "eu-tu", em que existiria um reconhecimento recíproco nos termos de que o eu, em alguns momentos e de acordo com alguns desejos, é igual ao outro. Adorno e Horkheimer (1986), quando fazem uma análise crítica da racionalidade, ou do esclarecimento, destacam que ela pode ser importante para contribuir para a emancipação do homem, mas pode também ser utilizada como instrumento de dominação e subordinação. Estabelece-se, assim, o conceito de racionalidade instrumental, que fortalece a lógica do "eu-isso" e da "coisificação dos indivíduos".

Nessa mesma linha, Bauman destaca que

não surpreende muito que essas pessoas vejam com um horror crescente a possibilidade de se encontrar face a face com estranhos. Estes tendem a parecer ainda mais assustadores na medida em que se tornam cada vez mais diferentes exóticos e incompre- 
ensíveis, e em que o diálogo e a interação que poderiam acabar assimilando a 'alteridade' se diluem e nem chegam a ter lugar (2004, p. 135).

Ainda segundo Baumam,

os patrícios de hoje não precisam mais dos serviços da comunidade; na verdade, não conseguem perceber o que ganhariam permanecendo na e com a comunidade o que já não tenham obtido por conta própria ou ainda esperam assegurar por seu próprio esforço, mas podem pensar em muitos recursos que poderiam perder caso se submetessem às demandas da solidariedade comunitária (2003, p. 50).

Em uma tentativa de reversão do quadro que em alguns momentos na sociedade contemporânea sinaliza a disjunção, a divisão e a exclusão social, buscam-se na teoria da dádiva de Mauss (1974) parâmetros para pensar que os seres humanos podem ter algo intrínseco que os liga aos seus semelhantes nesse mesmo mundo.

A dádiva como colocada nessa teoria está presente nas relações permeadas pela solidariedade. Godbout (1999) retrabalha essa teoria focalizando a sociedade contemporânea e destaca que a rede de relações interpessoais cimentadas pela dádiva e pelo auxílio mútuo se destacam como últimos baluartes que permitem a sobrevivência num mundo de carências materiais e de insegurança.

Segundo Mauss, existe um sistema de dádiva e trocas para além de questôes econômicas na vida social, no qual as pessoas trocam objetos, serviços, saberes, e estas trocas têm um peso simbólico ao mesmo tempo que propiciam a satisfação dos indivíduos, bem como a manutenção da própria vida social. Existe algo na coisa dada que faz com que os sujeitos sintam-se praticamente "obrigados" a retribuir uma gentileza, um presente, uma ajuda. Esse senti- 
mento Mauss chama de Hau, que significa, em linhas gerais, o "espírito do doador" que permanece na coisa dada. Nesta perspectiva, as relações são marcadas pela reciprocidade entre as pessoas, em que a doação material, espiritual e emocional acarreta uma dívida com o outro, no sentido de que se faça o mesmo por ele.

Segundo Lanna (2000), as dádivas perpassam e organizam diferentes esferas sociais ao se pautar na ideia de dar, receber e retribuir, no respeito mútuo e na generosidade recíproca. Encontra-se aí uma convergência com a teoria da luta por reconhecimento de Honneth, para quem

as formas de interação assumem nos casos normais o caráter de relações solidárias, porque todo o membro se sabe estimado por todos os outros na mesma medida; pois por solidariedade pode-se entender, numa primeira aproximação, uma espécie de relação interativa em que os sujeitos tomam interesse reciprocamente por seus modos distintos de vida, já que eles se estimam entre si de maneira simétrica (2003, p. 209).

Visto esse cenário, parte-se do pressuposto que discussões em torno da solidariedade no campo do turismo são fundamentais para suscitar debates que visam transformar os caminhos que vem seguindo a sociedade contemporânea por meio de um olhar crítico.

Feitas tais considerações sobre a solidariedade e suas proximidades com a dádiva, a seguir, estão algumas experiências que aliam turismo e solidariedade em sites pelo mundo.

\section{As diferentes características do turismo solidário}

Os casos apresentados nesse tópico, na maioria das vezes, estão relacionados ao oferecimento do turismo solidário como um produto, como uma forma de reinventar o mercado turístico, no 
qual cresce o número de turistas preocupados ou engajados em atividades voltadas para melhorias dos problemas socioambientais. Nesse sentido, Rodrigues destaca que

todos os anos é necessário criar novas experiências para seduzir os turistas e despertar neles o interesse pelo local. Trabalhar o turismo, nesse caso, requer trabalhar o imaginário local para criar novas proposta de marketing, ferramenta que constitui um recurso fundamental na era pós-moderna. Os agentes envolvidos no desenvolvimento do turismo devem sempre procurar despertar a sensibilidade do turista, estimulando a criatividade das comunidades para descobrir novas possibilidades de oferta turística (1999, p. 217).

Graburn (2001), ao comentar o turismo solidário, o relacionou com viagens praticadas em áreas pobres, que incluem os que viajam a Cuba para ajudar com as colheitas da cana-de-açúcar e com o desenvolvimento local e ecológico e os europeus que trabalham na Bolívia ajudando mineiros muito pobres a extrair estanho. Realça ainda o crescente sentido de responsabilidade moral por parte de muitos turistas, organizações não governamentais e alguns setores de promoção da atividade turística para proporcionar o turismo "amigo do pobre". Por meio de sites na rede mundial de computadores, constata-se que o termo turismo solidário está bastante difundido, mas possui vieses diferentes, configurando, assim, um conceito em formação.

O site www.turismosolidario.com.br apresenta o turismo solidário no Vale do Jequitinhonha da seguinte forma:

A proposta privilegia a valorização do jeito de ser, da cultura popular e das belezas naturais das comunidades. Os turistas solidários participam do cotidiano das famílias que os hospedam e têm a possibilidade de compartilhar um pouco de seu conhecimen- 
to. Possibilitando a troca de conhecimentos e geração de renda às populações locais, o programa significa esperança de vida melhor para centenas de famílias beneficiadas pelo aumento do fluxo turístico e pela participação solidária dos turistas.

No site português www.inatel.pt, o turismo solidário é apresentado como uma oportunidade para as pessoas com dificuldades financeiras usufruírem do turismo, como fica evidenciado nesta citação:

Poderão participar do Programa cidadãos residentes em Portugal com idade superior a 18 anos, com um rendimento bruto mensal igual ou inferior a dois salários mínimos nacionais; poderão ser acompanhados pelos cônjuges, e/ou outros membros dependentes do agregado familiar, independente da idade e nacionalidade destes. O custo do Programa varia consoante o valor de rendimento bruto mensal por pessoa (2011).

Na França, no site www.tourisme-solidaire.org, o turismo solidário assemelha-se ao caso do Vale do Jequitinhonha, tendo como foco a contribuição para habitantes dos países em desenvolvimento se fortalecerem economicamente. Organizações da sociedade civil fornecem apoio técnico às associações de moradores de países em desenvolvimento. Elas, portanto, trabalham com projetos de desenvolvimento local e incentivam as pessoas a viajar em direção aos locais carentes com o intuito de praticar o turismo solidário, tornando-se parte dos projetos de desenvolvimento.

Na Itália, no site www.turismosolidale.it, o turismo solidário é relacionado a outro tipo chamado de responsável e possui uma rede de associaçóes e entidades que promovem a atividade tanto no seu próprio território como nos países considerados mais pobres. 
Tanto a proposta francesa quanto a italiana defendem uma forma de turismo organizado pelas populaçôes locais, pois acreditam que dessa maneira o dinheiro pode circular na região contribuindo para o desenvolvimento local sem que haja a concentração da renda gerada pela atividade turística sob o controle de grandes agências (Bellia e Battesti, 2004). Assim, o turismo solidário também se aproxima do turismo de base comunitária, que tem como um dos seus pressupostos o envolvimento dos moradores de determinada região na atividade turística e a valorização da cultura local (Irving, 2009).

Uma agência de viagens da Argentina, Boomerang, oferece o turismo solidário como um dos seus produtos. Eis alguns trechos significativos retirados de www.boomerangviajes.com.ar:

Contemplan espacios de intercambio con comunidades locales. Participación de sus tareas cotidianas. Algunos programas contemplan alojamiento en casas particulares. Involucran a comunidades indígenas y rurales. Contamos con programas en Argentina, América, África y Asia... El viajero elige un destino a visitar. Por parte de Boomerang Viajes, se toma conocimiento sobre las motivaciones del viaje, los servicios requeridos por el viajero, el tiempo disponible, temporada y sus posibilidades económicas. El viajero es asesorado e informado acerca de los impactos que producirá su visita. El viajero identifica las necesidades básicas están cubiertas y realiza una propuesta en algunos casos las comunidades de base al contar ya con un proyecto se puede destinar un porcentaje para su desarrollo (2011). ${ }^{1}$

${ }^{1}$ Contemplar oportunidades de intercâmbio com as comunidades locais. Participação em suas tarefas diárias. Alguns programas incluem alojamento privado. Envolvimento das comunidades indígenas e rurais. Temos programas na Argentina, América, África e Ásia... O viajante escolhe um destino para visitar. Por meio da Boomerang viagem, toma-se conhecimento sobre as motivações da viagem, os serviços solicitados pelo viajante, o tempo disponível, temporada e seu potencial 
Já a Action, em seu site www.actionaid.org.br, apresenta-se como uma associação não governamental internacional, com atuação em quarenta países, e propõe

desafios aos doadores de todo o mundo, e já levou turistas solidários a China, Índia, Peru, Quênia, Tanzânia, Camboja, Malauí, Sri Lanka e Marrocos. Entre os objetivos do desafio, estão: arrecadar recursos para um fundo de emergências da organização, encurtar as distâncias entre países do Norte e do Sul e chamar a atenção para o quanto as pessoas pobres ainda precisam de ajuda. Para participar da aventura, cada interessado se compromete com a ActionAid a arrecadar um montante junto a amigos, empresas, associaçōes etc. e passa por um treinamento sobre como levantar fundos (2011).

Na Espanha, um programa de turismo solidário é organizado pela Fundação Bancaja e o seu principal objetivo é levar os turistas para conhecer associações e projetos solidários espalhados pelo mundo. É possível obter maiores informaçōes em www.obrasocial.bancaja.es/cultura/cultura.aspx.

O intercâmbio cultural é estimulado por meio da hospedagem em receptivos familiares. Em um vídeo da associação Bancaja, que pode ser encontrado no site www.youtube.com/ watch?v=eU5YQCzlmz8, uma turista solidária caracteriza sua viagem dizendo: "um pouquinho de coração e sensibilidade é a melhor forma de viajar do mundo", e um turista que parecia estar voltando à sua casa salienta o enriquecimento obtido com a viagem ao dizer: "eu vou mais rico [...]. As pessoas não precisam

econômico. O viajante é aconselhado e informado sobre os impactos que sua visita produzirá. O viajante identifica as necessidades básicas a serem atendidas e faz uma proposta; em alguns casos, destina um percentual de sua viagem para o desenvolvimento de projetos (tradução do autor). 
oferecer seus serviços para a viagem ser caracterizada como solidária”. Neste trecho, percebe-se, assim como no turismo solidário do Vale do Jequitinhonha, que ações voluntárias não são primordiais para caracterizar o turismo solidário.

Outra modalidade de turismo que se assemelha às propostas do turismo solidário é o reality tour oferecido pela Global Exchange, para quem

tours are not designed to provide immediate solutions or remedy the world's most intractable problems, nor are they simply a brand of voyeurism [...] A participant will have the chance to learn about unfamiliar cultures, meet with people from various walks of life, and establish meaningful relationships with people from other countries (2011). ${ }^{2}$

$\mathrm{Na}$ modalidade proposta pela cooperativa portuguesa Mó de Vida (www.modevida.com/turismo.html), uma agência emissiva, "o confronto com a realidade, tomando conhecimento no local visitado das desigualdades, injustiças etc. levará à adoção de atitudes mais solidárias nas suas vidas quotidianas".

Um dos casos mais significativos nessa abordagem é a organização dos estudantes da Universidade de Oxford, em que três deles, depois de uma viagem a regióes carentes da Geórgia, fundaram a Travelaid, com o intuito de organizar uma instituição que pudesse levar outros estudantes a terem experiências semelhantes. A instituição possui apoio da universidade e eles organizam viagens nas férias escolares para regiōes carentes para que os alunos possam colocar suas habilidades a serviço das populaçóes locais.

2 Os passeios não são projetados para fornecer soluções imediatas ou remediar problemas mais difíceis do mundo, nem são simplesmente uma marca de voyeurismo [...] Um participante terá a oportunidade de aprender sobre culturas desconhecidas, encontrar com pessoas de vários estilos de vida, e estabelecer relacionamentos significativos com pessoas de outros países (tradução do autor). 
Além disso, fazem campanhas para arrecadar fundos para os projetos sociais que se propóem a contribuir para o desenvolvimento de regiōes carentes economicamente.

\section{Turismo solidário: em busca de um conceito}

O turismo solidário está alinhado com as novas discussões da ciência na contemporaneidade e cumpre uma função social importante, pois integra diferentes olhares para compor o turismo como um fenômeno social complexo de múltiplas determinações.

Com a orientação da fenomenologia, pretendi apreender a essência do fenômeno (Husserl, 2008) por meio da descrição dos casos ocorridos no campo de pesquisa. De acordo com tal perspectiva teórica, após a etapa apontada,

o pesquisador, ao ler os discursos do sujeito, é orientado por um sentido, por uma busca de significados que ele intui ou detecta. As proposições ontológicas e epistemológicas representam as concepçôes sobre o fenômeno. As percepções que os sujeitos têm da sua experiência vivida passam a constituir os dados da pesquisa ou as 'unidades de significado' que compõem os elementos estruturais do fenômeno (Machado, 1994, p. 45).

As unidades de significados que compõem o turismo solidário foram sistematizadas por meio de "6 Vs" (visitação, vivências, vendas, vínculos, veiculação, validação). Essa abordagem faz uma alusão a outros campos do conhecimento, como o marketing, que usa a ideia dos "4 Ps" (praça, preço, promoção, ponto de venda), e da educação ambiental, dos " 4 Rs" (repensar, reduzir, reutilizar e reciclar), para suas sistematizações.

Os "6 Vs" são pensados em termos de doação e de recepção simultâneas, ou seja, todos são interdependentes, mas eventualmente podem ocorrer de forma isolada. Tem-se, portanto, uma 
abordagem complexa para promoção do turismo, cujos indicadores e significados sinalizam a sistematização e o acompanhamento dos processos turísticos. A seguir, apresento uma caracterização mais detalhada dos elementos a serem pensados em cada um dos "Vs" do turismo solidário.

\section{Visitação: roteiros baseados nos saberes locais}

Este indicador relaciona-se com a visitação impulsionada pelo fortalecimento de uma identidade territorial e pela valorização dos atrativos naturais. Tal fortalecimento aumenta a possibilidade da emergência de sujeitos políticos que influenciem a construção social da realidade e promovam a preservação ambiental a partir de novos vocabulários (Rorty, 2007).

Os trabalhos com roteiros baseados nos saberes locais proporcionam uma reflexão sobre a história das regiōes visitadas e sobre o sentimento de pertencimento dos moradores, evocando um diferencial para a região. Tal fato cria potencial de inovação do produto turístico. Tem-se percebido que os projetos sociais que ocorrem nas regiōes visitadas tornaram-se atrativos turísticos e, em muitos casos, os turistas se dispóem a contribuir com eles, seja com palestras, atividades em geral ou recursos financeiros.

Os estímulos às visitas e aos projetos comunitários que podem ocorrer durante a visitação são considerados essenciais, pois os sujeitos visitados podem se sentir motivados quando seus trabalhos são reconhecidos pelos turistas. Trabalha-se com a perspectiva de Wulf, para quem "a imagem de si próprio se forma e se transforma através da vida com o outro e o seu reconhecimento" (2003, p. 210).

Para fomentar a visitação baseada nos saberes locais, a história oral tem se apresentado como uma boa estratégia. A identidade territorial dá suporte a uma visitação como mais significado e é, portanto, indispensável no âmbito do turismo solidário. É impor- 
tante ressaltar que o entretenimento e o artesanato também são aspectos fundamentais para motivar a visitação do turista e podem ser pensados no planejamento da atividade.

\section{Vivências: aumento no nível de intimidade}

Este indicador relaciona-se às trocas de experiências, que fazem do campo turístico um ambiente propício para o aprendizado mútuo permeado por posturas solidárias. Observase que a procura por um turismo que prioriza a convivência com os moradores das localidades visitadas está crescendo e os encontros estão se apresentando como um diferencial, sendo capazes de alargar a percepção do indivíduo por meio dessas trocas (Fortunato e Neffa, 2010).

Durante as pesquisas no Vale do Jequitinhonha, foi possível ouvir os seguintes relatos: "eles vindo aqui conversando comigo já é uma boa ação, trazem informações importantes" (morador); "É bom conhecermos pessoas com a cabeça diferente da nossa, através deles podemos mudar a cabeça da gente e da comunidade para ver se surge uma nova alternativa aqui" (morador).

Uma estudante de medicina da UERJ realizou atividades voluntárias de promoção de saúde no Vale do Jequitinhonha. Essas práticas de educação em saúde foram explicitadas com maiores detalhes por Cruz e Fortunato (2009) no texto "Promoção de saúde por meio do turismo solidário no Vale do Jequitinhonha", apresentado no 47ํㅡㄹ Congresso Científico do Hospital Universitário Pedro Ernesto. Em relação a sua vivência, a estudante fez o seguinte relato:

É bastante importante lidar com pessoas de todos os tipos... é o que vou fazer em minha profissão [atualmente, ela é aluna do terceiro ano de medicina]... conhecer outras realidades, pois, apesar de você saber que existem lugares que não têm sanea- 
mento e acesso, a assistência médica restrita, é diferente você ir lá e ver... percepções diferentes de mundo... sensação de pureza [referia-se às pessoas das localidades], a receptividade das pessoas foi uma coisa muito impressionante... a pessoa nunca te viu e te oferece várias coisas... Será que ficar trancada em um consultório é o que quero com a minha profissão? Fiquei pensando nisso... gratidão... você tem a impressão de que você não fez nada demais e a pessoa agradece como se você tivesse feito muito... Eu quero fazer isso mais vezes... estou mais autoconfiante.

Os significados atribuídos às vivências relacionam-se diretamente ao tempo de permanência do turista na região visitada. Os encontros no campo do turismo solidário podem ser considerados momentos propícios para formação pessoal e ressignificação identitária, visto que símbolos e significados específicos, representados pela construção social de indivíduos em ambientes distintos, encontram-se como elementos relativizadores de pontos de vistas e de modos de ser e estar no mundo contemporâneo.

Para Rorty, é preciso estar atento ao vocabulário final de cada indivíduo com uma postura solidária, para que cada um possa ser capaz de reinventar seu vocabulário e torná-lo mais propício a vivências permeadas pela solidariedade.

Nenhum ser humano tem mais acesso à realidade do que outros, pois a "realidade" resiste às nossas descrições (Rorty, 2007), sendo, portanto, a diversidade de olhares e perspectivas o fermento que contribui para a criação de modelos de desenvolvimento alternativos. Nas palavras de Rorty, "o processo de mudança de linguagem e de outras práticas sociais pode produzir seres humanos de um tipo que nunca existiu antes" (2007, p. 32).

Para concluir esse tópico relacionado às vivências, é importante ressaltar que, quanto mais tempo o turista permanece em contato com a população, maior a probabilidade de ele destinar 
recursos financeiros aos lugares visitados e, por meio da compra de produtos e serviços, dinamizar a cadeia produtiva do turismo.

\section{Vendas: campanhas de marketing}

Este indicador procura entender o turismo como um fenômeno social que perpassa o campo da economia e dos negócios, pois alguns atores sociais que trabalham com o turismo solidário desejam melhorar sua qualidade de vida por meio da atividade. Assim, faz-se necessário pensar uma estratégia de marketing para estabelecer um posicionamento no mercado que garanta a sustentabilidade econômica das iniciativas. No Vale do Jequitinhonha, por exemplo, a prática é comercializada pelo sítio eletrônico www. turismosolidario.com.br.

Para pensar na venda de um produto, é de suma importância o conhecimento do perfil dos turistas. Swarbrooke e Horner (2002), ao discutir questôes referentes ao que chamam de "comportamento do turista do futuro", sinalizam as múltiplas influências relacionadas à escolha dos destinos e das atividades a serem exercidas no tempo de lazer das pessoas. As influências listadas são: fatores políticos, econômicos, sociais, da indústria do marketing, tecnológicos; a influência da mídia; experiência em viagens. Essas questōes, combinadas ao desejo de diferenciação por meio do consumo, fazem do campo do turismo um espaço dinâmico em estreita relação com valores sociais.

Surgem, desse modo, no plano da comercialização de produtos, estratégias de segmentação de mercado, que, na perspectiva de Kotler, traduzem-se na identificação de um grande grupo "a partir de suas preferências, poder de compra, localização geográfica, atitudes de compras e hábitos de compras similares" (2000, p. 278).

Para Urry, levar em consideração como os grupos sociais constroem seu olhar turístico é uma boa maneira de perceber o que está acontecendo na "sociedade normal": 
Não existe um único turista enquanto tal. Ele varia de acordo com a sociedade, o grupo social e o período histórico. Tais olhares são construídos por meio da diferença [...]. O olhar do turista, em qualquer período histórico, é construído em relacionamento com seu oposto, com formas não turísticas de experiências e de consciência social (2001, p. 16).

Assim, para se pensar em turismo na atualidade, há que se reconhecer, a partir da segunda metade do século XX, fatores sociais como o aumento das preocupações com o meio ambiente em seu sentido amplo e os novos discursos sobre responsabilidade social, em que a legislação ambiental e seus instrumentos para preservação e conservação ambiental ganham destaque.

Existem evidências de que parte da população mundial reconhece os limites dos usos dos recursos naturais e que a justiça social, entendida aqui como condições dignas para todo cidadão, pode ser uma premissa plausível para sustentar a ideia de desenvolvimento.

Comportamentos nessa direção passam a ser adotados por aqueles que pretendem legitimar suas ações como condizentes com a de um "cidadão responsável". A adoção, por exemplo, dos termos "eco", "sustentável" ou "solidário" torna-se também uma questão mercadológica de diferenciação e oferece evidências do perfil do público que pode se interessar pelo turismo solidário que ocorre em determinadas regióes.

\section{Vínculos: economia solidária e arranjos produtivos locais}

O trabalho no campo dos arranjos produtivos locais procura fortalecer a economia da região e incentiva o empreendedorismo a atuar na cadeia produtiva do turismo. Em algumas localidades em que o turismo ocorre, moradores oferecem, em suas casas, produtos para venda ou vagas em quartos. Apesar de 
ser uma estratégia de venda, tal fato pode ser pensado no campo dos vínculos, na medida em que o dono de um empreendimento indica outro para ser visitado. Isso fortalece a cadeia produtiva do turismo e as relações de reciprocidade e solidariedade.

É importante ressaltar que, no turismo, assim como em outras atividades econômicas, torna-se necessário pensar no desenvolvimento da região em detrimento do desenvolvimento exclusivamente individual.

O fortalecimento dos vínculos entre os agentes que trabalham com o turismo de forma direta ou indireta promove um ambiente de troca de informaçóes e tecnologias que formam redes e aumentam a competitividade da região no mercado turístico.

A formação e o fortalecimento dessas redes podem contribuir para o aumento dos trabalhos no campo da economia solidária, porque nesse campo pretende-se estreitar os vínculos entre os atores sociais que, até então, eram concorrentes.

Em linhas gerais, na economia solidária, os participantes na atividade econômica cooperam entre si em vez de competir (Singer, 2002). Trabalha-se na perspectiva da produção da existência, na qual a reciprocidade e a dádiva (Mauss, 1974) são consideradas elementos essenciais. Nesse sentido, a economia solidária se apresenta como um modelo alternativo, que, mesmo dentro do mercado capitalista, insiste na igualdade e na autogestão como pressupostos da organização da produção de bens materiais e serviços.

Nas pesquisas realizadas no Vale do Jequitinhonha, constatou-se que, apesar da importância do estabelecimento de vínculos para gestão do turismo solidário, os atores sociais ainda encontram grandes dificuldades. O relato de uma das técnicas do programa ilustra esse fato:

Eles pensaram que você teria um fluxo turístico mais rápido, que a capacitação para o estabelecimento de uma rede de serviços - vamos chamar de rede de serviços, hospedagem, transporte e 
alimentação, alguma coisa de artesanato que foi trabalhado em paralelo -, acreditavam que isso seria suficiente para uma divulgação e promoção do programa, tanto que foram realizadas algumas viagens de familiarização nesse sentido, mas eles não tinham a capacidade de recepção porque na verdade eles precisavam receber e operar. O mercado pediu produtos prontos e operadores, e até que isso fosse feito, gastou-se um tempo grande. Eu acho que inicialmente, os técnicos que começaram com o programa acreditavam que a resposta também de organização, de entrosamento das comunidades envolvidas, seria maior; achava-se que essas comunidades envolvidas dariam conta de estar gerindo o programa, o que foge da realidade.

Visto esse cenário, torna-se relevante a existência de redes de colaboração, como a Rede Brasilidade Solidária - que pode ser conhecida com maior profundidade no endereço www.brasilidadesolidaria.com -, pois nelas é possível compartilhar experiências nas quais a vinculação entre diferentes atores sociais é o ponto forte da gestão do turismo.

Quando está em pauta a questão dos vínculos no turismo solidário, não há como não fazer referência às amizades que se formam entre visitantes e visitados. Quando a viagem termina, é comum o envio de cartas e fotos por parte dos turistas e as promessas de que retornarão para visitar a região novamente.

\section{Veiculação: a responsabilidade social dos empreendimentos}

Neste indicador, entende-se veiculação como o ato de transmitir informaçôes relevantes para promoção da proteção ambiental, do esporte, da cultura e da justiça social aos turistas. Acredita-se na importância da responsabilidade socioambiental dos atores sociais envolvidos para sensibilizar os visitantes em relação aos problemas socioambientais, visto que o turismo é conhecido tam- 
bém por sua degradação ambiental e social ao inserir, por vezes, lógicas de produção e de consumo que não se sustentam.

A responsabilidade social, por exemplo, na visão de Parente et al., "sempre começa no âmbito pessoal e atinge o organizacional, pois se trata da decisão de um indivíduo, ou de um grupo, de agir de maneira coletiva. É a expansão da consciência que vai despertar maior responsabilidade pelo bem coletivo" (2006, p. 29).

Neste indicador, dá-se relevância para veiculações que se aproximam das bases filosóficas da educação ambiental, que procura contribuir para a formação do indivíduo. A Lei n. 9795/99, em seu artigo $1 \stackrel{\circ}{\text {, }}$, preconiza que

entendem-se por educação ambiental os processos por meio dos quais o indivíduo e a coletividade constroem valores sociais, conhecimentos, habilidades, atitudes e competências voltadas para a conservação do meio ambiente, bem de uso comum do povo, essencial à sadia qualidade de vida e sua sustentabilidade (Brasil, 1999).

A mesma lei apresenta a educação ambiental como uma ação a ser desenvolvida pela sociedade nos mais variados espaços. No artigo $3^{\circ}$, inciso VI, diz que cabe "à sociedade como um todo, manter atenção permanente à formação de valores, atitudes e habilidades que propiciem a atuação individual e coletiva voltada para a prevenção, a identificação e a solução de problemas ambientais".

O site www.turismosolidario.com.br, ao apresentar suas propostas de trabalho, afirma que o turismo solidário pode "despertar no turista: o compromisso de participar da transformação socioeconômica do país [...] valorizar a identidade cultural e a preservação dos atrativos culturais e naturais nas regiōes".

Uma das práticas de veiculação de informações pode estar relacionada à "história de vida" dos produtos comercializados e aos problemas socioambientais que se apresentam no empreendimento turístico e em seu entorno. Podem ser destacadas também 
as estratégias de superação dos problemas socioambientais por meio da prática do turismo solidário.

\section{Validação: reprodução da tecnologia social}

A validação pode ser entendida como o estágio no qual o turismo solidário praticado passa a ser reconhecido como um caso de sucesso por um grupo de pessoas. Uma das principais maneiras para validação é a capacidade de o empreendimento atuar em redes e contribuir para a disseminação da proposta, pois a atuação em redes pressupõe um intercâmbio e um posicionamento político e ideológico em torno de uma concepção do modo de organização dos produtos turísticos e das regiões turísticas.

Assim, pressupóe-se que os atores sociais que utilizam como uma de suas referências a Rede Brasilidade Solidária, por exemplo, estão desejosos de trocar experiências em relação às dificuldades e às potencialidades de seus trabalhos, para que outros indivíduos também possam se beneficiar. Trata-se, nesse ponto, de trabalhar de acordo com a proposta das ecologias de saberes e contra a experiência desperdiçada (Santos, 2006).

Este indicador é influenciado pelas discussões relacionadas às tecnologias sociais, que podem ser entendidas como

o conjunto de atividades relacionadas a estudo, planejamento, ensino, pesquisa, extensão e desenvolvimento de produtos, técnicas ou metodologias reaplicáveis, que representem soluções para o desenvolvimento social e melhoria das condições de vida da população (Brasil, 2013).

Acredita-se que o turismo solidário seja capaz de contribuir para a melhoria da qualidade de vida de determinadas populações, podendo ser pensado como uma tecnologia social que tem nos "6 
Vs" seus significados e suas diretrizes para acompanhamento dos processos turísticos.

\section{Apostando no turismo solidário}

O Brasil sediou a Copa do Mundo de 2014 e está prestes a receber as Olimpíadas de 2016, o que o coloca diante de uma importante oportunidade - e também de uma demanda de desenvolver o setor turístico. Espera-se que, além das capitais, os pequenos municípios e distritos também sejam afetados pelo aumento na quantidade de turistas, com a perspectiva de alguns deles buscarem um contato de maior intimidade com os moradores das localidades visitadas e de se preocuparem com as questôes socioambientais. Diante disso, supōe-se que um bom número de municípios, de regiōes, de localidades e de associaçōes de moradores investirá nessa nova demanda e buscará uma maneira de satisfazê-la.

Desse modo, a Rede Brasilidade Solidária se coloca à disposição da sociedade para contribuir com projetos de turismo que tenham interesse na utilização dos "6 Vs" como diretrizes de atuação. Faz-se isso pensando que, apesar das oportunidades do novo cenário turístico, existe grande quantidade de grupos e de pessoas que têm dificuldade em empreender um novo negócio no campo. Uma das formas de divulgação da rede e dessas oportunidades ocorre por meio do programa Retrato Brasil, que enfatiza a questão da convivência, da emoção e da motivação para que surjam novas iniciativas que contribuam para o desenvolvimento local por meio do turismo solidário. Esse programa pode ser visualizado no endereço http://www.youtube.com/user/RETRATOBRASIL.

Atualmente, o trabalho está sendo desenvolvido no Morro do Borel (RJ), em Barra de Guaratiba (RJ), no bairro dos Três Picos, em Nova Friburgo (RJ) e no Complexo do Alemão (RJ). Procura-se desenvolver uma nova concepção teórico-metodológica 
de trabalho, que busca preencher uma lacuna na relação entre os trabalhos acadêmicos e as pessoas que atuam ou querem atuar com o turismo. Procura-se, também, formar redes como uma maneira de manifestação política, partindo do pressuposto que os participantes dessas redes podem convergir, minimamente, em relação às diretrizes teóricas e metodológicas para atuação no campo do turismo.

O título "Brasilidade Solidária" foi pensado como uma estratégia de marketing, visando atingir a um público específico que busca, no contato com a população local e na troca de experiências, elementos que garantam a qualidade da sua viagem. É importante lembrar que, apesar de seguir as diretrizes dos "6 Vs", não se atua, necessariamente, a partir de concepções prévias em relação ao modo de dar prosseguimento aos trabalhos, a fim de evitar as armadilhas do determinismo e do mecanicismo. Vale ressaltar que o simples fato de fazer parte da rede não garante que os "6 Vs" já estão sendo trabalhados em todo seu potencial.

Neste capítulo, constatou-se a complexidade que envolve abordagens relacionadas ao turismo solidário. Sua base de sustentação ancora-se nas discussões referentes à educação ambiental, à economia, à psicologia, à política, à identidade, aos valores humanos, dentre outras áreas, revelando seu caráter transdisciplinar.

O turismo solidário é, portanto, um fenômeno social complexo com múltiplas determinaçôes, que, por meio de relaçôes interpessoais solidárias, sinaliza possibilidades de transformação pessoal e social e, eventualmente, envolve ações voluntárias para melhoria dos problemas socioambientais.

$\mathrm{O}$ aumento no grau de intimidade entre os sujeitos envolvidos no encontro faz do turismo solidário uma busca por pessoas, mais do que por paisagens. O outro é o diferencial, é o que mais importa, é o responsável por aumentar os repertórios temáticos pelos quais os indivíduos são capazes de "circular" (Fortunato, 2013). 
Essas características atribuídas aos encontros abrem possibilidades para pensar neles como fenômenos que estimulam o reconhecimento, a convivência, a valorização do saber local, o fortalecimento da economia local e a preservação ambiental. Diante desse cenário de potencialidades das abordagens relacionadas ao turismo solidário, um dos próximos passos da Rede Brasilidade Solidária será oferecer a universidades e universitários produtos turísticos que de alguma forma perpassam o conceito do turismo solidário.

A ideia é que os jovens possam desfrutar do prazer da atividade e, durante um período do seu tempo, se colocar à disposição das populações a fim de tentar contribuir para a melhoria dos problemas socioambientais. Essas atividades poderão fazer parte do seu currículo de atividades complementares.

Por fim, nesse modelo de turismo, "percebe-se que a estima recíproca entre sujeitos que compartilham modos de vidas escolhidos/construídos de formas diferenciadas contribui para o aumento do grau de solidariedade" (Fortunato, 2013) e que a solidariedade, em conjunto com a atividade turística, pode ser uma boa estratégia para a construção de outros modos de se viver na sociedade contemporânea.

\section{Referências}

ACTIONAID. Disponível em http://www.actionaid.org.br/Portals/0/Releases/ Especial/turismo_solidario.pdf. Acesso em 2 fev. 2011.

ADORNO, T. W. e HORKHEIMER, M. Dialética do esclarecimento: fragmentos filosóficos. Rio de Janeiro: Jorge Zahar, 1986.

BACHELARD, G. A formação do espirito cientifico: contribuição para uma psicanálise do conhecimento. Rio de Janeiro: Contraponto, 1996.

BANCAJA. Disponível em http://www.obrasocial.bancaja.es/cultura/cultura. aspx. Acesso em 22 jan. 2013.

BAUMAN, Z. Comunidade: a busca por segurança no mundo atual. Rio de Janeiro: Jorge Zahar, 2003. 
Amor líquido: sobre a fragilidade dos laços humanos. Trad. Carlos Alberto Medeiros. Rio de Janeiro: Jorge Zahar, 2004.

BELLIA, R. e BATTESTI, N. R. "Tourisme solidaire: innovation et réseau. Analyse comparée France-Italie". Colloque Les Enjeux du Management Responsible. Lyon: Université Catholique de Lyon, 2004, pp.18-9.

BOOMERANGVIAJES. Disponível em http://www.boomerangviajes.com.ar/ espanol/turismosolidario.php. Acesso em 5 abr. 2011.

BRASIL. Lei n. 9.795 de 27 de abril de 1999. Dispóe sobre a educação ambiental, institui a Política Nacional de Educação Ambiental e dá outras providências. Disponível em http://www.planalto.gov.br/ccivil_03/leis/19795.htm. Acesso em 20 fev. 2014.

—_. Disponível em http://www.brasil.gov.br/sobre/ciencia-e-tecnologia/ desenvolvimento-sustentavel/tecnologia-social. Acesso em 10 mar. 2013

BUBER, M. Eu e tu. São Paulo: Centauro, 2001.

CAPALBO, C. Fenomenologia e ciências humanas. Rio de Janeiro: Âmbito Cultural, 1987.

CRUZ, H. T. e FORTUNATO, R. A. "Promoção de saúde por meio do turismo solidário do Vale do Jequitinhonha". Revista do Hospital Universitário Pedro Ernesto, Rio de Janeiro, 2009, a. 8, pp. 205-6.

DURKHEIM, E. Da divisão social do trabalho. 2 ed. São Paulo: Martins Fontes, 1999.

FORTUNATO, R. A. Turismo solidário e a redescrição social no Vale do Jequitinhonha-MG (tese). UERJ, 2011.

__ "Encontros no campo do turismo solidário do Vale do Jequitinhonha MG”. Revista Turismo \& Sociedade, Curitiba, jan. 2013, v. 6, n. 1, pp. 104-23.

— e NEFFA, E. M. "Entraves e potencialidades de açōes voluntárias na região do Programa de Turismo Solidário do Vale do Jequitinhonha”. Revista Turismo \& Sociedade, Curitiba, out. 2010, v. 3, n. 2, pp. 185-202.

GAXIOLA, N. C. "Hacia uma epistemologización del discurso turístico". In CASTILLO, N. M. Epistemologia del turismo: estúdios críticos. México: Trilhas, 2010.

GLOBAL EXCHANGE. Disponível em http://www.globalexchange.org/tours/ faq.html. Acesso em 2 fev. 2011.

GODBOUT, J. T. O espirito da dádiva. Trad. Patrice Charles F. X. Wuillaume. Rio de Janeiro: Editora FGV, 1999.

GRABURN, N. "Secular ritual: a general theory of tourism”. In SMITH V. e BRENT M. (orgs.). Hosts and guests revisited: tourism issues of the 21st century. Nova York: Cognizant Communication Corporation, 2001, pp. 42-50.

HONNETH, A. Luta por reconhecimento: a gramática moral dos conflitos sociais. São Paulo: Ed. 34, 2003. 
HUSSERL, E. A ideia da fenomenologia. Lisboa: Ediçōes 70, 2008.

INATEL. Disponível em http://www.inatel.pt/Turismo/programas/solidario. pdf. Acesso em 2 fev. 2011.

IRVING, M. de A. "Reinventando a reflexão sobre turismo de base comunitária: inovar é possível?”. In BARTHOLO, R. et al. (orgs.). Turismo de base comunitária: diversidade de olhares e experiências brasileiras. Rio de Janeiro: Letra e Imagem, 2009.

KOTLER, P. Administração de marketing: a edição do novo milênio. São Paulo: Prentice Hall, 2000.

LANNA, M. "Nota sobre Marcel Mauss e o ensaio sobre a dádiva". Revista Sociologia e Política, Curitiba, jun. 2000, n. 14. Disponível em http://www.scielo. br/scielo.php?script=sci_arttext\&pid=S0104-44782000000100010\&lng=p t\&nrm=iso. Acesso em 18 ago. 2009.

MACHADO, O. V. "Pesquisa qualitativa: modalidade fenômeno situado". In BICUDO, M. A. V. e ESPOSITO, V. H. S. (orgs.). A pesquisa qualitativa em educação: um enfoque fenomenológico. Piracicaba: Unimep, 1994, pp. 35-46.

MAUSS, M. "Ensaio sobre a dádiva. Forma e razão da troca nas sociedades arcaicas". Sociologia e antropologia. Trad. Paulo Neves. São Paulo: EDUSP, 1974 , v. 2.

MÓ DE VIDA. Disponível em http://www.modevida.com/turismo.html. Acesso em 2 fev. 2011.

MORIN, E. Ética, solidariedade e complexidade. São Paulo: Palas Athena, 1998. - O método. Porto Alegre: Sulina, 2005, 6 v.

NICOLESCU, B. O manifesto da transdisciplinaridade. São Paulo: Triom, 1999. PANOSSO, A. Filosofia do turismo. Teoria e epistemologia. São Paulo: Aleph, 2005.

PARENTE, J. G. et al. "Varejo e responsabilidade social". In —— e GELMAN, J. J. Varejo e responsabilidade social: visão estratégica e práticas no Brasil. Porto Alegre: Bookman, 2006.

RAMÍREZ, C. U. "Reflexiones sobre epistemologia del turismo". In CASTILLO, N. M. Epistemologia del turismo: estúdios críticos. México: Trilhas, 2010.

RODRIGUES, A. B. Turismo e espaço: rumo a um conhecimento transdisciplinar. 2 ed. São Paulo: Hucitec, 1999.

RORTY, R. Contingência, ironia e solidariedade. São Paulo: Martins, 2007.

SANTOS, B. S. Renovar a teoria crítica e reinventar a emancipação social. São Paulo: Boitempo, 2007.

SINGER, P. Introdução à economia solidária. São Paulo: Fundação Perseu Abramo, 2002.

SWARBROOKE, J. e HORNER, S. O comportamento do consumidor no turismo. Trad. Saulo Krieger. São Paulo: Aleph, 2002. 
TOURISMESOLIDAIRE. Disponível em http://www.tourisme-solidaire.org/ ressource/pdf/ts_reseau.pdf. Acesso em 4 abr. 2011.

TRAVELAID. Disponível em http://www.travelaid.org.uk. Acesso em 22 jan. 2013.

TURISMOSOLIDALE. Disponível em http://www.turismosolidale.it. Acesso em 23 jan. 2013.

TURISMOSOLIDARIO. Disponível em http://www.turismosolidario.com. br. Acesso em 20 mar. 2013.

TURNER, V. e TURNER, E. Image and pilgrimage in Christian culture. Nova York: Columbia University Press, 1978.

THIOLLENT, M. Metodologia da pesquisa-ação. São Paulo: Cortez, 2005.

URRY, John. O olhar do turista: lazer e viagens nas sociedades contemporâneas. São Paulo: Studio Nobel / SESC, 2001.

WULF, C. "O outro na perspectiva da educação intercultural”. In LOPES, C. M. (org.). Representação e complexidade. Rio de Janeiro: Garamond, 2003. 


\title{
Turismo e saúde: discussão de uma política de saúde do viajante no Brasil
}

\author{
Vanina Heidy Matos Silva \\ Christovam Barcellos
}

O cenário mundial de economia globalizada nos coloca frente a mudanças substanciais nas relações de produção e consumo. Em um contexto econômico de transformaçôes e incertezas, o turismo emerge com sua característica de "indústria do lazer" e com a perspectiva de um setor de serviços como alternativa de desenvolvimento.

A previsão é de que o turismo receptivo internacional chegue a quase 1,6 bilhão de viagens até o ano de 2020 (UNWTO, 2001). Dessa parcela, o Brasil já recebeu cerca de 5 milhões de turistas internacionais em 2008. No entanto, a movimentação interna foi muito mais expressiva e alcançou em novembro de 2010 a marca de 61 milhões de pessoas em circulação no país, isto é, mais de cem vezes que o turismo externo (MTur, 2010). Entre os municípios brasileiros, o Rio de Janeiro destaca-se como um dos principais receptores de turistas, com uma atividade considerável em aeroportos, na rodoviária e no porto (Riotur, 2011). 
A intensificação das atividades turísticas requer preocupação com o controle de território e fronteira, elementos de destaque na economia e na política mundial, principalmente no que diz respeito a surtos, epidemia e pandemias, que podem se tornar emergências de saúde pública de interesse nacional e internacional (Carmo et al., 2008; Castelli, 2004). A pandemia de influenza A (H1N1) em 2009 foi um exemplo que estremeceu a economia do turismo e revelou fragilidades da vigilância em saúde relacionadas ao campo das doenças infecciosas, especialmente das doenças transmissíveis emergentes e reemergentes.

A dinâmica da movimentação de pessoas e os impactos de saúde-doença individuais e coletivos sugerem a dimensão da complexidade de um assunto capaz de significar um problema desafiador tanto no plano local quanto global. Nesse sentido, novos desafios estão traçados pela existência de transportes cada vez mais rápidos e pela aceleração do fluxo de patógenos, além da oferta diversificada e facilitada financeiramente de múltiplos roteiros de viagem para áreas inóspitas ou de doenças endêmicas. É importante pensar na "possibilidade real do trânsito de viroses pelo mundo em poucas horas, cruzando continentes através das viagens aéreas" (Marques, 1995, p. 361).

Dentro desse contexto, a questão da saúde do viajante/turista apresenta-se como ponto importante para a construção de uma política nacional colocada em discussão no setor público brasileiro. Esse tema perpassou as áreas de vigilância em saúde nos últimos anos, tanto no âmbito sanitário, com a necessidade de implantação do Regulamento Sanitário Internacional, quanto no epidemiológico, com a crescente demanda de investigação de surtos envolvendo turistas. Já no setor de turismo, pode-se dizer que esses acontecimentos apresentam certa preocupação, principalmente em relação à diminuição das viagens. Entretanto, tem-se observado pouca contribuição desse setor para a saúde pública e para a minimização dos impactos na saúde dos turistas. 
Este estudo objetivou buscar junto aos gestores de saúde e de turismo propostas de como efetivar uma política de saúde para o viajante/turista e procurou esclarecer as responsabilidades de cada setor.

\section{Materiais e métodos}

Esta pesquisa lida com os atores sociais envolvidos em suas relaçóes com o objeto da saúde do turista segundo recorte do espaço social, e não com as estruturas de saúde e de turismo. Trata-se de uma investigação de natureza qualitativa, que nessa modalidade de elaboração do conhecimento nos oferece um quadro de interpretações e elementos para a compreensão de processos não quantificáveis (Minayo, 2008).

Foram selecionados gestores públicos do setor de saúde e de turismo que atuam no município do Rio de Janeiro nos níveis municipal e estadual e gestores do nível federal para discutir sobre os elementos que podem contribuir para a construção de uma política pública nacional de saúde do viajante/turista.

A amostra não probabilística se constituiu de 16 entrevistas: 12 com gestores do setor de saúde e quatro do setor de turismo. Os entrevistados da saúde compõem a área de vigilância em saúde e de vigilância sanitária. No setor de turismo foram selecionados gestores que atuavam em gestão de políticas públicas em turismo e na gestão de informação e dados em turismo.

Esses setores foram escolhidas como prováveis áreas que poderiam estar envolvidas no processo de formulação de uma política de saúde do viajante/turista. Todos os entrevistados autorizaram a entrevista pela assinatura do "Termo de consentimento livre e esclarecido".

Os dados foram coletados por meio de dois roteiros de entrevista semiestruturados, um dirigido aos gestores de saúde e outro, aos gestores de turismo. As questôes foram agrupadas como: 
caracterização dos gestores (saúde e turismo); problemas de saúde relacionados à atividade do turismo; sistemas de informação e a saúde do turista; vigilância em saúde do turista; política nacional de saúde do viajante/turista; e promoção da saúde do turista.

As entrevistas foram agendadas e realizadas individualmente, registradas com gravador de voz digital e transcritas na íntegra para análise dos dados. O período das entrevistas compreendeu os meses de agosto a dezembro de 2010. A duração do total de 16 entrevistas foi de nove horas e 38 minutos, com uma média de 36 minutos cada uma.

Para sistematização dos resultados foi realizada uma análise de conteúdo de base temática como técnica de pesquisa, feita a partir do aparecimento de termos e palavras (Minayo, 2008; Richardson, 2008), para, assim, compreender o objeto a partir da fala dos gestores. A categoria informação emergiu para discussão sob diferentes aspectos e foi, então, subdividida em: informação sobre o turista; sistema de informação; e informação para o turista.

Esta pesquisa foi submetida ao - e aprovada pelo - Comitê de Ética em Pesquisa da Escola Nacional de Saúde Pública Sergio Arouca da Fundação Oswaldo Cruz (CEP/ENSP/Fiocruz), sob o parecer n. 177/09, segundo a resolução n. 196/96 do Conselho Nacional de Saúde (Brasil, 1996).

\section{Resultados}

No setor de saúde, os servidores dos níveis municipal e estadual possuem maior tempo no desempenho das atividades em saúde pública, fundamentalmente em vigilância em saúde, e alguns possuem experiência ainda com a assistência e a promoção de saúde. No âmbito nacional, os gestores de saúde atuam com vigilância em saúde, sistemas de informação em saúde e vigilância em saúde nas fronteiras. $\mathrm{Na}$ área de turismo, os servidores atuam 
na gestão de políticas públicas em turismo e na gestão de informação e dados em turismo (quadro 1).

Quadro 1: caracterização dos gestores entrevistados

\begin{tabular}{|c|c|c|c|}
\hline Gestor saúde & Nível & Instituição & Tempo serviço \\
\hline GS1 & \multirow{3}{*}{ Municipal } & \multirow{3}{*}{ SMSDC-RJ } & 32 anos \\
\hline GS2 & & & 30 anos \\
\hline GS3 & & & 18 anos \\
\hline GS4 & \multirow{4}{*}{ Estadual } & \multirow{4}{*}{ SESDEC-RJ } & 10 anos \\
\hline GS5 & & & 33 anos \\
\hline GS6 & & & 20 anos \\
\hline GS7 & & & 23 anos \\
\hline GS8 & \multirow{5}{*}{ Federal } & \multirow{2}{*}{ SVS/MS } & 4 anos \\
\hline GS9 & & & 12 anos \\
\hline GS10 & & \multirow{3}{*}{ Anvisa } & 3 anos \\
\hline GS11 & & & 8 anos \\
\hline GS12 & & & 2 anos \\
\hline Gestor turismo & Nível & Instituição & Tempo serviço \\
\hline GT1 & \multirow{3}{*}{ Municipal } & \multirow{2}{*}{ Riotur-RJ } & 10 anos \\
\hline GT2 & & & 10 anos \\
\hline GT3 & & Comtur-RJ & 2 anos \\
\hline GT4 & Federal & CNTUR & 33 anos \\
\hline
\end{tabular}

Fonte: organização dos autores.

\section{Problemas de saúde relacionados à atividade do turismo}

A conexão entre a atividade do turismo e a existência de problemas de saúde foi identificada por todos os entrevistados, e 
foi unânime para os gestores da área de saúde a questão da circulação de pessoas como veículo de disseminação de doenças contagiosas, doenças transmissíveis e a circulação de novos patógenos que podem proporcionar o desenvolvimento de situaçôes de risco. Essa preocupação aparece quando o turista vem de fora do país ou quando realiza atividades de turismo de natureza:

Nós nos preocupamos muito com eles [...] principalmente aquele grupo que se desloca pra fazer turismo ecológico, turismo de aventura [...] essas pessoas estão entrando em áreas com potencial de transmissão de várias doenças, várias viroses, sem tomarem as devidas precauçóes que esse tipo de atividade merece [...] ainda é grande o número de pessoas que se deslocam pra área de transmissão silvestre de febre amarela sem cobertura vacinal [...] nos preocupam doenças pulmonares adquiridas em entradas de cavernas, onde há colônias grandes de morcegos [...] preocupa junto com a febre maculosa brasileira [...] as malárias de transmissão silvestre características de mata atlântica (GS5).

Um dos gestores de turismo apontou que "qualquer problema de saúde é capaz até de cancelar ou de adiar uma viagem" (GT3), tratando a questão como um impacto negativo para a área. Preocupado com a imunidade do turista estrangeiro, outro gestor de turismo citou como exemplo a prática de visitação turística em favelas do Rio de Janeiro, apoiada pela Riotur: "essas favelas não têm tratamento sanitário como deveriam, razão pela qual várias pessoas dentro da favela têm doenças, e os turistas que vêm de fora não têm nenhuma imunidade prevista para as centenas de doenças que eles podem adquirir" (GT1).

O turista foi colocado como vítima preferencial de problemas de saúde, de acordo com afirmativas apresentadas aos entrevistados para que concordassem ou não (quadro 2). 


\section{Quadro 2: afirmativas em relação à saúde do turista}

A) O turista é uma vítima preferencial de problemas de saúde porque não possui imunidades para infecçôes

B) O turista é uma vítima preferencial de problemas de saúde porque tem um comportamento que o expóe mais e não domina os códigos locais

C) O turista ajuda a espalhar as doenças porque circula de lugares endêmicos para não endêmicos, trazendo agentes patogênicos

D) O turista é uma vítima preferencial de problemas de saúde porque $o$ sistema de saúde no local de destino não está preparado para atendê-lo

E) O turista é uma vítima preferencial de problemas de saúde porque não detém as informaçôes necessárias sobre os riscos

F) O turista é uma vítima preferencial de problemas de saúde porque o sistema de saúde no local de origem não tem políticas específicas de prevenção e promoção

G) O turista é uma pessoa como outra qualquer e não tem riscos específicos

Fonte: organização dos autores.

$\mathrm{Na}$ visão dos gestores, as afirmativas $\mathrm{B}, \mathrm{C}$ e $\mathrm{E}$ foram ratificadas unanimemente. Em relação ao turista ajudar a espalhar as doenças por circular de lugares endêmicos para não endêmicos, um gestor de saúde do nível estadual destacou:

É muito mais perigoso o que entra do que sai, porque eles têm lá vírus respiratórios com potencial de gravidade muito alto que nós não temos aqui [...] não existe ainda nenhuma avaliação, mas empiricamente a gente percebe que muitos vírus de transmissão respiratória acometem a população aqui com a chegada da alta de transatlânticos vindos do exterior [...] no verão exatamente que é o pico de atracação desses navios aqui (GS5).

Todos discordaram da afirmativa G. E entre as justificativas mais apontadas está a que o não domínio dos códigos locais coloca o turista como uma pessoa com riscos específicos. A vulne- 
rabilidade aparece a partir de situações como o turista em contato com novos ambientes, em viagem mais longas ou com falta de informações sobre sua saúde: "essa é uma mentira total [...] os turistas são os mais vulneráveis pelo fato de ficarem mais tempo disponíveis e visitando lugares diferentes" (GT1).

Segundo um gestor de saúde, exposição e informação estão relacionadas: "esse é um aspecto que o torna vulnerável em relação a estar se envolvendo na sua viagem com algum problema de saúde se não houver a informação e a medida adequada de prevenção para as situações que são preveníveis" (GS3).

Os gestores que discordaram da afirmativa $\mathrm{D}$, sobre as condições de atendimento ao turista, são da área de turismo. Os que concordaram destacaram a importância da organização do sistema de saúde no local de destino, pensando no município do Rio de Janeiro:

Se o sistema estivesse organizado, essa condição de vítima ou de espalhar doença estaria neutralizada, seriam anulados (GS1).

Existem situações que não são preveníveis e que escapam da possibilidade de qualquer intervenção através de uma vacina [...] nesse sentido acho que a existência de uma estrutura que dê muito claramente as referências e os apoios em relação à assistência à saúde $[. .$.$] tem que estar garantida dentro da estrutura$ de funcionamento da rede (GS3).

No nível estadual, porém, um gestor entende que precisa de uma infraestrutura de saúde pública melhor para a população brasileira, a qual absorva também o turista. Outro problema nesse caso são os custos no atendimento ao turista estrangeiro e o ressarcimento do Estado: 
$\mathrm{Na}$ verdade, esse turista vai ter um seguro internacional [...] ele para no serviço público [...] o Estado atende e gasta recurso e tudo fica por isso mesmo, quer dizer, isso deveria ser regulado de forma que o seguro saúde dessa pessoa fosse registrado em algum documento e ele depois reembolsasse o Estado, por que é um absurdo, você vai pro exterior ninguém faz isso [...] em termos de administração de saúde pública eu acho isso uma grande perda (GS7).

Das pessoas que discordaram da afirmativa A, sobre as condições imunológicas do turista, três são da área de saúde, sendo duas do nível federal (GS8, GS12) e uma do estadual (GS6), e duas são da área de turismo, uma do âmbito municipal (GT2) e outra do federal (GT4). Dez entrevistados concordaram com a questão, e um gestor justificou: "dependendo de onde ele venha, ele vai entrar numa área em que já existe um padrão de imunidade elevado e ele vai ser uma pessoa que não tem imunidade pra aquela doença [...] então ele aqui é uma vítima preferencial porque ele não tem imunidade" (GS5).

$\mathrm{Na}$ afirmativa $\mathrm{F}$, foi praticamente unânime o consenso da ausência de políticas específicas de prevenção e promoção para o turista no local de origem da viagem.

O uso da palavra "vítima" foi desaprovado por dois entrevistados da Anvisa: "((riso)) eu só não entendo é [...] de vítima [...] eu acho que a pessoa se expõe mais ao mais vulnerável [...] vítima eu acho que é mais passiva” (GS11), "eu só acho vítima muito forte ((riso))" (GS12).

\section{Sistema de informação e saúde do turista}

Foram destacadas as frequências e observações sobre o grupo de questões relacionadas aos sistemas de informação na saúde e no turismo (tabela 1). A subnotificação foi uma preocu- 
pação levantada por um gestor de saúde municipal que concorda com a inserção de uma variável específica de identificação do viajante/turista (GS2). Ele explicou que é preciso realizar um trabalho de conscientização da importância do preenchimento de certo campo em formulários, como foi o caso da inserção da variável "raça/cor". Outra questão lembrada foi quanto à obrigatoriedade de preenchimento on-line do campo "estado nutricional", que tinha $80 \%$ de não preenchimento: "o grande problema é as pessoas preencherem [...] se você estiver fazendo on-line e ele só entrar como tópico obrigatório [...] o viajante [...] o pessoal vai responder" (GS2).

Tabela 1: sistemas de informação e saúde do turista

Questão

Nova variável no Sinan sobre o turista ${ }^{a}$

$\operatorname{Sim}$

Não (explorar as existentes)

Não respondeu
Número / Observações

Construir um sistema de informação específico ${ }^{\text {b }}$

Sim

Nenhum

Não

Não sei (criar bancos paralelos)

Já existe (Sispafra - Anvisa)

Não respondeu (sem informação) 3

\section{Dados na Anvisa}

Declaração de saúde do viajante (desativada)

Sistema Sagarana houve a necessidade na epidemia de influenza A (H1N1) controle de embarcaçôes/porto 
Sistema Sispafra

informação e emissão de

certificado de vacinação - CIVP

\section{Dados no turismo}

Trabalha com dados secundários

IBGE, Polícia Federal, pesquisas (Vox Populi, FGV)

${ }^{a}$ Pergunta dirigida aos gestores de saúde, não Anvisa / n=9.

${ }^{b}$ Pergunta dirigida a todos os gestores de saúde / n=12.

Fonte: organização dos autores.

Outros gestores identificaram que essa nova variável no Sistema de Informação de Agravos de Notificação (Sinan) poderia dar subsídio para sistematizar as ações de vigilância em saúde do turista, acompanhar as condições de saúde em termos mundiais e facilitar o monitoramento das principais doenças endêmicas, além de distinguir o tipo de viajante: "talvez fosse a hora de a gente discutir campos adicionais que pudessem complementar essa investigação [...] para detalhar se é um turista [...] espaço para o seguro saúde internacional [...] começar a pensar essa questão do ressarcimento" (GS7).

A possibilidade de inserção de uma nova variável para identificação do viajante/turista nos sistemas de informação de saúde, como o Sinan, foi desaprovada por dois gestores da saúde, um do nível municipal e outro do nacional, que explicou:

No exercício do uso das informações sobre o local de notificação, o local de residência, até o local da hospitalização, e principalmente na comparação do local de residência com o local provável de infecção, existente na maioria das fichas de investigação dos agravos notificados a partir da suspeição, e que são de notificação compulsória no país, e publicados atualmente na portaria 2472 [...] eu acho que já poderia se identificar esses viajantes [...] também é possível utilizar a informação sobre deslocamento, algumas fichas têm informação detalhada de até três locais em que o 
paciente percorreu nos últimos dez ou quinze dias, varia de uma ficha pra outra, informando até nível de município inclusive, o meio de transporte e a data [...] então eu acho que primeiro tem que fazer esse exercício (GS9).

A construção de um sistema de informação específico de saúde sobre o viajante/turista foi desaprovada por todos os gestores, sendo que três justificaram já existir na Anvisa um sistema com orientações gerais ao viajante, como os locais de vacinação contra a febre amarela e emissão do Certificado Internacional de Vacinação e Profilaxia (CIVP), exigido para entrada em alguns países.

Nas fronteiras nós não temos médico, enfermeiros à disposição. Se não informarem pra gente que tem alguém doente a bordo, nós não temos como rastrear essa pessoa [...] num ônibus é quase difícil, é quase impossível, a mesma coisa até a aeronave [...] às vezes há uma conivência da tripulação em não informar porque provavelmente vai atrasar um pouco as escalas [...] isso é motivo também de auto de infração sanitária [...] hoje nós estamos trabalhando com um sistema informatizado Sagarana, mas ainda esta funcionalidade não foi habilitada, exatamente porque nós não estamos diante de nenhuma ameaça neste momento (GS10).

$\mathrm{Na}$ Anvisa a gente tem muita dificuldade de desenvolver sistema de informações [...] a gente coloca lá informaçōes bem básicas [...] aquele cara que vai lá buscar o certificado [...] a nacionalidade lá pra saber quantos estrangeiros eu atendo [...] as vacinas a gente não tem orientado o pessoal de colocar todas as vacinas, só febre amarela [...] tem lugar que atende trezentas pessoas por dia e aí ia inviabilizar [...] também quando fazem o roteiro com a gente, tem lá pra onde essa pessoa viajou [...] só que eu nunca trabalhei nesse banco de dados, nunca parei pra trabalhar [...] até tinha muita dificuldade de ter acesso ao próprio banco de dados 
por uma questão lá da Anvisa em relação ao poder, que é muita informação [...] a gente nunca usou isso, essa informação [...] nunca tem nem relatório (GS11).

Um gestor de turismo destaca que no turismo nunca foi gerado algum tipo de dado com relação a ocorrências de saúde específicas de turistas. Critica a ausência e a maneira de geração de dados, além do uso da informação para as análises do turismo no Brasil:

A cultura a dados e a estatística nesse país é muito pouca [...] na área do turismo é bem pior ainda [...] os números são meio surrealistas, os 10\% são um número assim cabalístico, eles usam pra quase tudo [...] eles pegam dados de registro, no caso do turista internacional [...] da Polícia Federal [...] que é uma coisa incoerente, que não é função dela [...] o Ministério aproveita e cria o anuário dele [...] é questionado sim, porque tem alguns portões que tem muito daqueles muambeiros, principalmente nas fronteiras terrestres [...] então esse dado não é $100 \%$ confiável, mas é uma das poucas informaçōes que a gente tem com relação ao turista internacional [...] com relação ao turista doméstico já foram feitos dois ensaios [...] não teve continuidade [...] então você não tem uma série histórica (GT2).

Outro gestor do setor de turismo cita como exemplo o uso dos dados da Ficha Nacional de Registro de Hóspedes (FNRH), da Embratur, exigida no check-in de hotéis:

A gente está falando de dados estatísticos de pesquisa, dá um pulo na Turisrio, no $12^{\circ}$ andar, você vai ver num galpão mofando aquelas fichas, elas não servem para nada [...] na realidade ela serve, por exemplo, se você for assaltado, se você morrer, tem um contato, tem alguma coisa drástica [...] usar aqueles dados 
pra planejar o turismo, planejar a saúde do viajante, não vejo e nunca vi isso acontecer (GT3).

\section{Vigilância em saúde do turista}

A questão "Como a vigilância em saúde trabalha no Brasil com os problemas de saúde relacionados ao turista?", colocada principalmente aos gestores de saúde, foi unanimemente respondida pela inexistência de um olhar específico ao viajante/turista. No nível municipal, um gestor destacou que a vigilância em saúde continua atuando com os problemas do "dia a dia", e não com um "planejamento, uma organização, de uma atenção à saúde do viajante" (GS3). O vínculo de sintomatologia também é pouco valorizado na vigilância em fronteiras, segundo outro gestor de saúde municipal: "eu vejo que tem uma preocupação alfandegária [...] ninguém está preocupado com uma pessoa que chega espirrando porque ninguém valoriza o espirro ou o estado febril [...] nem no aeroporto, nem no porto, e principalmente na rodoviária” (GS1).

Já a ausência de identificação do indivíduo turista, feita pela atenção primária, foi apontada por dois gestores de saúde estadual como dificuldade de a vigilância epidemiológica atuar sobre esse grupo: "infelizmente, no serviço, principalmente na ponta [...] atendimento emergência, ambulatório, ainda não se tem a prática de fazer vínculos com atividades de lazer" (GS6), "ainda não tem nenhuma preocupação com os viajantes” (GS4).

Para um gestor de saúde do nível nacional, a vigilância em saúde não possui um foco no turista em si, "mas indiretamente ele é foco por dois meios, na regulamentação sanitária internacional [...] e os eventos de massa" (GS8).

Para a vigilância sanitária, a atuação de vigilância em saúde nas fronteiras existe e é atuante, inclusive na fronteira terrestre. No entanto, nesse ponto "já é municipal, o trabalho é municipal, o que a Anvisa faz é na fronteira geográfica mesmo [...] terrestre 
entre dois países" (GS10). Outro gestor da Anvisa reforça que "o trabalho da Anvisa em portos, aeroportos [...] também tem essa ação em fronteiras, que às vezes fica um pouco esquecida porque fica longe daqui, da realidade que a gente que vive nos centros" (GS12).

Na questão "O Ministério da Saúde conhece o perfil epidemiológico do viajante brasileiro? E do internacional que visita o Brasil?", dos 12 entrevistados do setor saúde, oito responderam que não existe essa informação, e que, se a encontrássemos, seria precária, "não seria um dado bom" (GS5).

Até onde eu sei, não conheço nenhum estudo, nenhum artigo, nem nenhum relatório técnico feito pelo Ministério da Saúde relativo à saúde de pessoas que viajam [...] seja de brasileiros que saem do país, ou das pessoas que visitam o país [...] mas eu acredito que existem informações suficientes pra fazer uma descrição [...] levantando hipóteses nos sistemas de informações existentes no Brasil, a exemplo do Sinan (GS9).

\section{Política nacional de saúde do viajante/turista}

Foi apontado aos entrevistados o desenvolvimento de políticas específicas do Ministério da Saúde com ações programáticas, como saúde da criança, saúde da mulher, saúde do homem, saúde do idoso, saúde mental, saúde do trabalhador e outras. Nesse contexto, a importância ou necessidade de uma política de saúde do viajante/turista no Brasil foi questionada, e a inexistência de informação sobre essa população foi a principal justificativa:

Em saúde pública existem lá uma série de condições se a gente vai considerar aquilo um problema de saúde pública para construir um programa [...] uma delas é a questão da viabilidade, factibilidade, viabilidade financeira, viabilidade técnica, efetivi- 
dade [...] precisa ser pensada, pois hoje eu acho que nem pensada é [...] que tipo de programa vai ser criado, ou se vai se criar um programa, ou se dentro de cada área técnica do ministério que faz o controle, a avaliação das medidas tomadas, vai ter uma área voltada pra essa questão do turismo [...] isso é o início (GS5).

Todos esses programas foram pensados a partir de fenômenos que levavam ou que poderiam levar ao óbito [...] o viajante eu acho que ele ainda não se enquadra aqui [...] as coisas só vão tomar esse rumo com a introdução de novos patógenos aqui que levem ao óbito [...] para a saúde do viajante se tornar um programa de saúde do viajante vai precisar acontecer uma tragédia [...] eu não sei como é o comportamento sanitário do turista nacional ou internacional aqui no Brasil (GS6).

Eu acho que a gente precisa de mais dados, mais informação para ver se realmente seria necessária uma política nacional de vigilância da saúde do viajante [...] teria que ser alguma coisa talvez com uma visão transversal (GS7).

Acho que é falta de informação mesmo porque a gente não tem, não vê essa análise sendo feita [...] a menos que seja feita uma coisa especial para o viajante ele vai ter então privilégios [...] que é possível (GS9).

É política só de desconhecimento [...] o pessoal não tem noção de quanto é importante para a manutenção, vamos dizer, de certa estabilidade no país (GS12).

Três gestores (dois da saúde e um do turismo) concordam que a política de saúde do viajante/turista seja transversal dentro do Sistema Único de Saúde (SUS), uma ação de Estado para todos, e corroboram a necessidade de informação: 
Não sei se como programa [...] mas como um componente em cada uma dessas linhas de atuação, dessas linhas de cuidado, não tenho dúvida [...] não existem informações ou dados que nós temos hoje em dia que permitam identificar quais são as ações estratégicas [...] dentro da saúde do viajante a gente tem que construir as informaçōes (GS3).

Tem que ter saúde pra todos e parar nesse país [...] com esse negócio de você criar segmentos [...] você lota verbas às vezes para uma coisa que não são usadas adequadamente se o planejamento fosse feito para todos [...] planejadas para a cidade como um todo [...] acho importante é a área de saúde desenvolver isso para todo mundo (GT2).

Tem que ser uma ação de Estado para a população em geral que eventualmente vai viajar [...] o status de viajante não é integral, é temporal (GS1).

A importância de uma política específica de saúde do viajante/turista foi ratificada por um gestor da saúde e dois do turismo. Um deles destacou os eventos de massa que acontecerão no Rio de Janeiro: "eu acho importante e oportuno pelo momento que o Rio de Janeiro vive [...] jogos militares, Copa do Mundo, Olimpíadas" (GT3). No entanto, a transferência de responsabilidade apareceu na fala do gestor de saúde federal (GS8) para o nível estadual, e do gestor de turismo municipal (GT1) para o nível federal de saúde:

Sim, primeiro é necessário fechar as diretrizes [...] a saúde do viajante é saúde no sentido vigilância [...] profilaxia [...] assistência [...] orientação, comunicação [...] a relevância da questão do viajante é fortalecida pelo regulamento sanitário internacional [...] pelos jogos de massa, pelo fortalecimento de fronteiras [...] 
poderia estar mais avançado tecnicamente [...] talvez precisasse que cada estado criasse um setor só do viajante [...] na organização do serviço a saúde do viajante tá fragmentada ainda (GS8).

O Ministério do Turismo, eu não sei se o ministério iria [...] transferir essa responsabilidade para o Ministério da Saúde (GT1).

\section{Promoção da saúde do turista}

A melhor forma de promover a saúde do viajante/turista no Brasil, na opinião dos gestores da saúde, envolveu informação, qualificação profissional e integração dos setores: "por meio da informação" (GS2), "tem que pensar em conjunto" (GS4), "internet, acompanhamento da informação acessível para o turista, para o profissional de turismo informado do que está acontecendo" (GS6), "a Anvisa já tem informação para o turista [...] qualificação do profissional de turismo feita pela Anvisa” (GS12).

Para os gestores de turismo, além da informação, a importância de sensibilizar o poder público foi destacada: "dispor canais de informação para o turista, essas informações poderiam dar mais ênfase ao que pode oferecer de problemas ao turista" (GT1), "sensibilizar o trade turístico, profissional de turismo, sensibilizar o poder público" (GT3).

Outra questão apontada pelo setor de turismo foi a integração dos ministérios:

Hoje será absolutamente fundamental que o Ministério da Saúde ingresse no Conselho Nacional de Turismo [...] mas como o Ministério da Saúde também não tem a clareza do turismo na saúde, porque não é só o turismo não ter a clareza da saúde no turismo, eu acho que não há clareza da saúde sobre a questão do turismo também (GT4). 
A maioria dos gestores acha que a responsabilidade sobre a saúde do viajante/turista cabe aos dois setores: "é uma parceria" (GS2), "tem que ter uma abordagem intersetorial" (GS3), "eu acho que o turismo podia dar pelo menos um mínimo de orientação [...] a área da saúde, eu acho que ela não consegue ter o acesso ao turista antes de ele ficar doente" (GS4).

$\mathrm{Na}$ visão de um gestor da Anvisa, "a área de saúde tem que andar junto com o turismo [...] orientando, informando [...] não adianta você punir" (GS12). Um gestor de saúde acredita que a responsabilidade não é aderida por nenhum dos setores: "sinceramente, vai depender do interesse [...] acaba ficando mesmo para o próprio turista" (GS6).

Um gestor de turismo acha que "cabem parcelas iguais"; no entanto, replica que "a missão de cuidar da saúde do turista é muito mais da Secretaria de Saúde" (GT1). Outro gestor de turismo entende que "a responsabilidade do setor público ou do gestor público em relação ao turista é a mesma que ele tem em relação ao cidadão" (GT2).

A palavra informação foi referida oitenta vezes pelo setor da saúde ( 45 ocorrências com gestores municipais) e 16 vezes pelo setor do turismo (14 ocorrências com gestores municipais).

\section{Discussão}

A informação teve destaque na fala de quase todos os gestores das duas áreas e foi um item prevalente nas respostas das diferentes perguntas feitas aos entrevistados. A incapacidade, alegada pelos gestores, de discutir o tema da saúde do viajante/turista está explícita na discussão pela incipiência de informação.

Por isso, a informação foi privilegiada para a discussão neste artigo e nos levou a pensar uma política de saúde do viajante/turista subdividida em: informação sobre o turista; sistema de informação; e informação para o turista. Existem os espaços da saúde 
do turista em que o fluxo de informação depende de cada etapa, mas a produção da informação acontece em momentos diferentes (figura 1). Essas três frentes de informação enfatizadas referem-se ao campo institucional (Ayres et al., 2006), ou seja, são responsabilidade tanto do governo quanto das empresas.

Figura 1: o fluxo da informação nas lacunas da saúde do turista

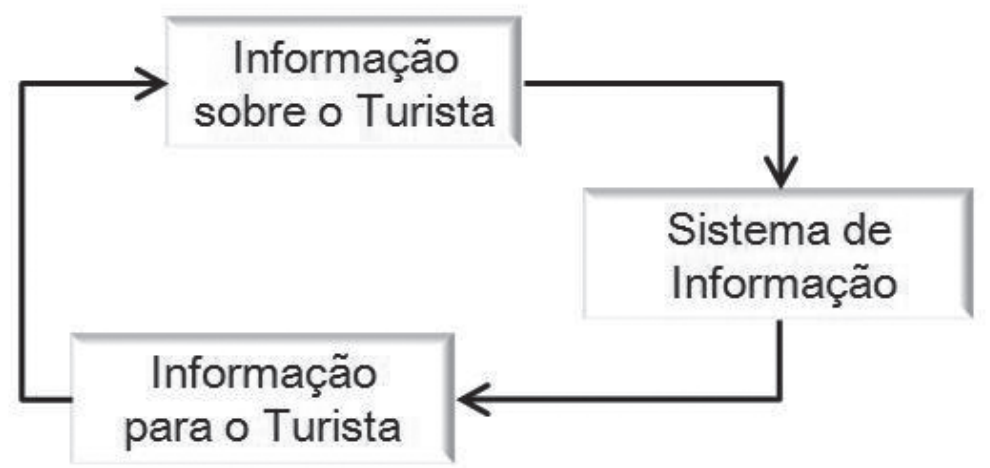

Fonte: organização dos autores.

A importância de uma política de saúde do viajante/turista foi considerada pelos gestores. Entretanto, quanto à necessidade dessa política, em primeiro lugar, quase todos do setor de saúde demonstraram incerteza e disseram precisar pensar mais sobre o tema. Em segundo lugar, a informação sobre o turista se destaca claramente como necessária para uma política de saúde para o viajante/turista. Outros termos referidos à demanda da informação (quadro 3) estabelecem a configuração das três fases sugeridas na figura 1 e traduzem, por sua relevância, o substrato da discussão deste artigo. 


\begin{tabular}{|c|c|c|}
\hline Informação sobre o turista & Sistema de informação & Informação para o turista \\
\hline Informação técnica & Administrar informação & Canal de informação \\
\hline Informação clínica & Circular informação & Transmitir informação \\
\hline Perfil de informação & Disseminar essa informação & Ação de informação \\
\hline Partir da informação & Trazer essa informação & $\begin{array}{l}\text { Dar informação consis- } \\
\text { tente }\end{array}$ \\
\hline Fonte de informação & Produzir informação & Sites de informação \\
\hline Coletar informação & Utilizar a informação & $\begin{array}{l}\text { Usar mais os postos de } \\
\text { informação }\end{array}$ \\
\hline $\begin{array}{l}\text { Relação com determinada } \\
\text { informação }\end{array}$ & Informação difundida & Melhorar a informação \\
\hline Informação precoce & $\begin{array}{l}\text { Avaliar o uso da informa- } \\
\text { ção }\end{array}$ & $\begin{array}{l}\text { Turista de fora tem infor- } \\
\text { mação suficiente }\end{array}$ \\
\hline Informação detalhada & $\begin{array}{l}\text { Informação sobre morta- } \\
\text { lidade }\end{array}$ & $\begin{array}{l}\text { Riscos relacionados à falta } \\
\text { de informação }\end{array}$ \\
\hline Informação é poder & $\begin{array}{l}\text { Informação sobre hospita- } \\
\text { lização }\end{array}$ & Falta informação para o \\
\hline $\begin{array}{l}\text { Falta um pouco mais de } \\
\text { informação }\end{array}$ & Buscar essa informação & turista de dentro \\
\hline $\begin{array}{l}\text { Está carecendo de infor- } \\
\text { mação }\end{array}$ & $\begin{array}{l}\text { Nunca usou essa infor- } \\
\text { mação }\end{array}$ & \\
\hline $\begin{array}{l}\text { Precisa mais dados, mais } \\
\text { informação }\end{array}$ & Trabalha com informação & \\
\hline $\begin{array}{l}\text { Com informação você pode } \\
\text { tomar atitudes }\end{array}$ & Cadastra essa informação & \\
\hline
\end{tabular}

* As expressóes foram recortadas das falas, sem qualquer ajuste ou alteração. Fonte: organização dos autores.

Quando um dos gestores de saúde (nível estadual) enfatiza que "a referência para a instalação de uma política de saúde no 
Brasil é o indicador de óbitos" (GS6), confirma que todos os programas no país (saúde da criança, da mulher, do idoso, outros) foram pensados sob o aspecto de redução da mortalidade. Como não se conhece o perfil epidemiológico do viajante/turista nem na morbidade, nem na mortalidade, a orientação de uma política para essa população não tem precedência. A frase "para a saúde do viajante se tornar um programa [...] vai precisar acontecer uma tragédia" (GS6) mostra claramente o não reconhecimento do viajante/turista nas análises da saúde. Mesmo com a "tragédia" de óbitos da pandemia de influenza A (H1N1) em 2009, a sistematização de dados sobre os casos em turistas não foi concretizada de modo acessível e disponível.

Para um gestor da Anvisa, "as políticas públicas têm um sistema de priorização [...] se faz exatamente conhecendo esses dados estatísticos, a magnitude, a transcendência do risco envolvido" (GS10), entretanto, não existe essa informação sobre o turista no Brasil. Outro gestor da Anvisa aponta que, mesmo no desconhecimento, a questão sanitária do viajante está sendo revista pelo Regulamento Sanitário Internacional (2005) em vigor, ou seja, "todos os países que aderiram a ele vão ter que se adequar" (GS12), como é o caso do Brasil. Isso mostra que a saúde do viajante/turista poderá ser reconhecida, quem sabe, como um problema de saúde global, independentemente da ignorância de todas as suas dimensões.

Nesse sentido, a dicotomia entre uma política específica e uma política transversal transitou ora pela condição circunstancial de turista, ora pela emergência do controle de fronteiras e o sucesso dos eventos de massa. Como transversal, a política deveria se inserir em todo o SUS, "porque o viajante é idoso, é mulher, é trabalhador [...] é criança, é adolescente” (GS3). Como específica, novamente, "a relevância da questão do viajante é fortalecida pelo Regulamento Sanitário Internacional” (GS8). 
No momento em que todos discordam da afirmativa de que o turista é uma pessoa qualquer e não tem riscos específicos, é uma incoerência, especialmente para a saúde pública, não ter informação da saúde dessa população. E quando dois gestores da Anvisa discordam do termo "vítima", suscitado intencionalmente, sugerem que o turista está sendo tratado como "coitadinho", enquanto, na realidade, ele escolhe se expor aos problemas de saúde, e, por isso, talvez não mereça uma política. Esse fato deixa transparecer, inclusive, a diferença entre as visões sobre vigilância sanitária e vigilância epidemiológica e indica uma das dificuldades de como observar o turista no aspecto da saúde.

A produção de informação sobre a saúde do turista está atrelada, primeiro, à identificação desse sujeito em diversos pontos na trajetória da viagem (Monken e Barcellos, 2005) - no caminho, no destino - e, segundo, à organização do sistema de saúde para atender ao turista. A vigilância do deslocamento do turista, então, caberia aos setores de saúde e de turismo integrados (Ruiz-deChavez et al., 1994), que identificariam, notificariam e alimentariam um banco de dados e um sistema que gerassem informação de saúde sobre o turista.

É clara a necessidade de sistematização e circulação da informação entre os setores de saúde e de turismo. Ao mesmo tempo, a ausência dessa informação sobre o turista praticamente anulou a discussão sobre em qual nível de governo - municipal, estadual ou federal - deveria ser alocada a política. Se não existe informação para pensar sobre a política, como deduzir de quem é o encargo? Assim, o "tênue jogo de empurra", no caso específico dos gestores entrevistados, parece existir meramente pela incipiência de discutir a questão em cima do abstrato. Ressalta-se que a deficiência de informação incomodou mais aos gestores do nível municipal.

Em comparação, vale destacar que a saúde gera dados primários e o turismo não gera dados, trabalha com fontes secun- 
dárias. Longe de abster a responsabilidade do setor turístico, essa situação localiza uma direção para a saúde.

Com o objetivo de levantar informação para intervir em ações concretas e usá-la na formulação de políticas públicas, surgiram na década de 1970 os sistemas de informação em saúde. Em 1975, o Ministério da Saúde estabeleceu um Sistema de Vigilância Epidemiológica com vários desafios a enfrentar, como a tarefa de padronizar o instrumento de registro de óbito unificado pela Declaração de Óbito (DO). Esses dados alimentam o Sistema de Informação sobre Mortalidade (SIM), o primeiro a ser criado e implantado entre 1975 e 1979. Na década de 1990, foram criados o Sistema de Informação sobre Nascidos Vivos (Sinasc, em 1994), baseado na Declaração de Nascido Vivo (DN, em 1990), e o Sistema de Informação sobre Agravos de Notificação (Sinan, em 1995), com a função principal de registrar dados de morbidade, restrito a doenças transmissíveis (Santos et al., 2004). Nesse mesmo período, ocorreu o processo de informatização dos sistemas de informação, e a regulamentação pactuada obrigou as secretarias municipais de saúde a adotar o Sinan, com a finalidade de fortalecer todo o sistema de vigilância em saúde do Brasil (Brasil, 2006, 2010).

Parece existir um empenho por parte da Organização Mundial do Turismo (OMT) em promover o desenvolvimento de sistemas nacionais de estatísticas do turismo para a comparabilidade internacional e análise macroeconômica do setor (UNWTO, 2001, 2008). De acordo com a OMT, a criação desse sistema deve ser aderida pelos governos locais, e da parte brasileira essa responsabilidade caberia ao Ministério do Turismo, que não possui um sistema de informação, nem mesmo dados que possam ser utilizados na análise da situação da saúde do turista.

No entanto, um gestor do turismo municipal (GT2) não acredita que exista algum movimento em relação à sistematização de dados do setor no Brasil. A própria movimentação de turistas é levantada por meio de acordos entre instituições não compe- 
tentes a essa atribuição, como a contagem da Polícia Federal nas fronteiras internacionais, o que pode gerar um dado inconsistente e insuficiente. Até então, o uso da informação no setor turístico é dado por estudos encomendados a institutos de pesquisa, como o Instituto Brasileiro de Geografia e Estatística (IBGE). É, portanto, uma contradição um setor essencialmente de serviços, de viés econômico - com interesse no lucro e em ativar a cadeia produtiva -, não produzir dados.

O desafio legitimado nessa discussão está em como construir uma política de saúde do turista sem conhecer as informações sobre a magnitude dos problemas que impactam essa saúde, bem como a extensão desse impacto na saúde coletiva por meio da atividade do turismo e da movimentação de pessoas. Um sistema de informação nacional que abrangesse a especificidade do turista facilitaria o monitoramento de agravos de interesse da saúde pública, o controle sanitário das fronteiras e, principalmente, direcionaria as ações de promoção sobre qual informação transmitir ao turista.

Para construir políticas públicas, é necessário gerar dados, transformá-los em informações, e estas em instrumentos com a capacidade de fundamentar a ação de gestores, a priorização e a avaliação. Segundo os entrevistados, o SIM e Sinan seriam os sistemas de informação mais adequados para a exploração de dados e para a descrição do perfil epidemiológico dos viajantes/turistas, visto que não existe uma variável específica para identificação imediata dessa população nos instrumentos de registro dos dados.

Do mesmo modo, sabe-se que, para a implantação de uma nova política ou de qualquer nova ação governamental no país, existe a necessidade de recursos financeiros, diretrizes, além de interesses políticos, econômicos e sociais (Motta, 2006). Certamente, a construção de uma política de saúde do viajante/turista no Brasil requer ainda muita discussão até alcançar formulações de instrumentos para sua fundamentação e execução. 
Alguns gestores da saúde sugeriram que a Agência Nacional de Saúde Suplementar (ANS) se responsabilizasse pela regulação da assistência ao estrangeiro no SUS, como forma de reverter os gastos com o turista internacional, em comparação a outros países que não oferecem serviço de saúde gratuito. É necessário discutir mais se as instituições citadas devem ser envolvidas e como seria esse envolvimento. Haverá distinção entre os tipos de viajantes, como refugiados ou moradores de fronteiras, que usam o SUS? Para se pensar em restituir o sistema, é preciso informação de gastos, o quanto se atende de estrangeiro, quem é esse viajante, e definir, com base no princípio de universalidade do SUS (Brasil, 2003), se esse procedimento seria admissível.

Diferentes entendimentos surgiram quanto à questão da imunidade do turista, uns trataram como aspecto individual e outros como coletivo, com a existência de um padrão geográfico de imunidade (Randolph e Rogers, 2010).

"A promoção da saúde demanda uma ação coordenada entre todas as partes envolvidas: governo, setor saúde e outros setores sociais e econômicos" (Brasil, 2002, p. 21). A ação de informar ao viajante sobre prevenção de saúde é vista como um risco de diminuir a entrada de turistas. É válido alinhar essa inquietação com o setor de saúde, para que o viajante/turista não seja ignorado, nem visto como vítima, e muito menos como ameaça.

Para a promoção da saúde do turista, tanto os gestores da saúde quanto do turismo consideraram fundamentais a informação para o turista, a qualificação do profissional do turismo e a sensibilização do trade turístico, do poder público e de grandes entidades.

\section{Agradecimentos}

Este estudo é parte da tese $A$ saúde do viajante na visão de três atores: gestores da saúde pública, gestores do turismo e o turista. 
O projeto teve apoio da Fundação Oswaldo Cruz na forma de bolsa de doutorado para Vanina Heidy Matos Silva. Christovam Barcellos é bolsista de produtividade do Conselho Nacional de Desenvolvimento Científico e Tecnológico (CNPq). Agradecemos a participação dos gestores de saúde e de turismo que responderam à entrevista.

\section{Referências}

AYRES, J. R. C. M. et al. "Risco, vulnerabilidade e práticas de prevenção e promoção da saúde". In CAMPOS, Gastão Wagner de Sousa et al. Tratado de saúde coletiva. Rio de Janeiro: Hucitec/ Ed. Fiocruz, 2006, pp. 375-417. BRASIL. Resolução n. 196 de 10 de outubro de 1996. Diretrizes e normas regulamentadoras de pesquisas envolvendo seres humanos. Brasília: Conselho Nacional de Saúde (CNS), 1996.

BRASIL. As cartas da promoção da saúde, Projeto Promoção da Saúde. Brasília: Ministério da Saúde, 2002.

BRASIL. Legislação do SUS. Brasília: Conselho Nacional de Secretários de Saúde (Conass), 2003, $604 \mathrm{p}$.

BRASIL. Vigilância em saúde no SUS: fortalecendo a capacidade de resposta aos velhos e novos desafios. Brasília: Ministério da Saúde / Secretaria de Vigilância em Saúde, 2006, 226 p.

BRASIL. O sistema de informação de mortalidade: origem e evolução. Disponível em http://tabnet.datasus.gov.br/tabdata/sim/dados/cid9/docs/intro.pdf. Acesso em 29 dez. 2010.

CARMO, E. H. et al. "Emergências de saúde pública: conceito, caracterização, preparação e resposta”. Estudos Avançados, São Paulo, 2008, v. 22, n. 64, pp. 19-32.

CASTELLI, F. "Human mobility and disease: a global challenge". Journal of Travel Medicine, Atlanta, USA, jan. 2004, n. 11, pp. 1-2.

MARQUES, M. B. "Doenças infecciosas emergentes no reino da complexidade: implicaçōes para as políticas científicas e tecnológicas”. Cadernos de Saúde Pública, Rio de Janeiro, jul.-set. 1995, v. 11, n. 3, pp. 361-88.

MINAYO, M. C. S. O desafio do conhecimento: pesquisa qualitativa em saúde. 11 ed. São Paulo: Hucitec, 2008.

MINISTÉRIO DO TURISMO (MTur). “Já chega a 61 milhões o número de desembarques nacionais”. Dados e Fatos, Brasília, 29 dez. 2010, s. p. Dispo- 
nível em http://www.dadosefatos.turismo.gov.br/dadosefatos/geral_interna/ noticias/detalhe/20101229.html. Acesso em 15 jan. 2011.

MONKEN, M e BARCELLOS, C. "Vigilância em saúde e território utilizado: possibilidades teóricas e metodológicas". Cadernos de Saúde Pública, Rio de Janeiro, mai.-jun. 2005, v. 21, n. 3, pp. 898-906.

MOTTA, R. S. Economia ambiental. Rio de Janeiro: Ed. FGV, 2006.

ORGANIZAÇÃO MUNDIAL DA SAÚDE (OMS). Regulamento Sanitário Internacional (RSI). Genebra: Organização Mundial da Saúde, 2005.

RANDOLPH, S. E. e ROGERS, D. J. "The arrival, establishment and spread of exotic diseases: patterns and predictions". Nature Reviews Microbiology, Londres, mai. 2010, v. 8, n. 5, pp. 361-71.

RICHARDSON, R. J. Pesquisa social: métodos e técnicas. 3 ed. São Paulo: Atlas, 2008.

EMPRESA DE TURISMO DO MUNICÍPIO DO RIO DE JANEIRO S. A. (RIOTUR). Informativo estatístico: verão Rio 2010-2011. Rio de Janeiro: Departamento de Estatística Riotur, 2011.

RUIZ-DE-CHAVEZ, M. et al. "Salud y turismo". Salud Pública, Morelos, México, 1994, v. 36, n. 1, pp. 61-9.

SANTOS, S. M. et al. "Informação e diagnóstico de situação de saúde". Informação e diagnóstico de situação. Rio de Janeiro: Fiocruz/EPSJV/Proformar, 2004, pp. 112-64.

UNITED NATIONS AND WORLD TOURISM ORGANIZATION (UNWTO). Recommendations on tourism statistics. Luxenburgo / Madri / Nova York / Paris: United Nations publication, 2001. Disponível em http:// unstats.un.org/unsd/publication/SeriesF/SeriesF_80E.pdf. Acesso em 22 fev. 11.

. International recommendations for tourism statistics, 2008. Disponível em http://unstats.un.org/unsd/tradeserv/IRTS\%202008\%20edited\%20 whitecover.pdf. Acesso em 20 out. 2014. 


\section{História e cultura urbana carioca: a natureza turística do Rio de Janeiro entre a cidade das letras e a cidade maravilhosa}

Amanda Danelli Costa

\section{Chegar ao Rio de Janeiro por mar}

A cidade do Rio de Janeiro tem a sua gênese marcada por uma história de disputas. A primeira delas é, mais do que um embate entre civilizações, uma disputa entre projetos de cidades ideais. Os franceses, que já haviam construído a sua França Antártida em terras cariocas, foram chamados à luta pelos portugueses, que, além de não quererem perder seu território, pretendiam fazer daquele um espaço fértil para a sua empresa colonial. Assim, a cidade se constituiu a partir de um confronto de utopias entre franceses e portugueses (Rodrigues, 2006, p. 213). Diante da cidade que os franceses haviam imaginado e criado, os portugueses assumiram a condição de afirmar e garantir a sua força frente à ameaça estrangeira. Essa força, entretanto, que poderia estar apenas baseada no domínio das terras e na construção 
de fortificações, promoveu a idealização do novo espaço pelos colonos que ali se instalaram.

A segunda das disputas se desenrolou na medida em que franceses e portugueses precisavam, ao mesmo tempo, se aliar e negociar com os nativos, para quem o Rio de Janeiro se apresentava como espaço real, onde a vida estava marcada pela força do cotidiano e da tradição indígena.

Para os portugueses, sua idealização supôs [...] o reencontro com homens. No fundo, com dois tipos diferentes de homens. Um, europeu, reconhecido como inimigo, uma vez que ocupava uma área de domínio português e precisava ser excluído dessas terras. Outro, da terra, índio, que, influenciado pelas atitudes e modos de agir dos franceses, considerava-se dono de um domínio português sem ser portador de qualquer qualificação que lhe garantisse a posse das terras (Rodrigues, 2002, p. 17).

Esses dois momentos foram decisivos para que no ano de 1565 a cidade fosse fundada ${ }^{1}$ aos pés do Morro Cara de Cão, na boca da Baía de Guanabara, lugar que desde então funcionou como uma dobradiça da cidade, permitindo, por um lado, o contato com seu caráter mais particular e, por outro, com o que é estrangeiro. Essa qualidade da Baía de Guanabara fez dela não apenas um marco da fundação da cidade, mas passou a integrar o espírito da cidade, que desde muito cedo se tornou cosmopolita, aberta ao mundo. Tal característica foi garantida ao longo dos

1 Mem de Sá e seu sobrinho, Estácio de Sá, dedicaram-se à organização das expediçôes para, finalmente, em 1567 expulsarem os franceses desse território. Estácio de Sá, que em 1565 havia lançado os fundamentos da cidade de São Sebastião do Rio de Janeiro, morreu ferido no rosto por uma flecha, em razão dos combates contra os franceses e seus aliados tamoios. 
séculos seguintes pela presença e direção dos colonos, ${ }^{2}$ que garantiram que a cidade fosse sutilmente deslocada da autoridade dos colonizadores, então marcada pela "experiência da vida ativa contra a vivência contemplativa, pela autonomia e pelo autogoverno" (Rodrigues, 2002, p. 19).

A terceira das disputas persiste na cidade até os dias de hoje, quando a natureza ainda impõe os limites para a dominação do espaço. Depois de expulsarem os franceses e dominarem os nativos, os portugueses tiveram de avançar sobre a natureza tropical da cidade para definitivamente ocupá-la. Além disso, a natureza é um dos elementos presentes no jogo de tensóes entre a beleza primitiva, a cultura e a civilização; jogo este que resulta em diversas imagens que ainda hoje representam a cidade do Rio de Janeiro. Foi justamente dessa tensão, em que ora pesam as qualidades associadas à beleza primitiva e ora pesa o seu caráter mais cultural, que nasceu seu mais conhecido epíteto: cidade maravilhosa.

A natureza no Rio de Janeiro revela a condição feminina do seu espírito através das curvas que seduzem quem a conhece. É feminina também porque as mesmas curvas desafiam a potência de quem investe sobre ela; e ainda dissimulam os seus defeitos. Essas qualidades da natureza do Rio, sintetizadas na conjugação das curvas do solo e do espelho d'água da Baía de Guanabara, vão integrar o espírito da cidade.

A partir da pequena fortaleza natural da colonização portuguesa, a ação de urbanização permitiu ocupar um território pouco propenso a isso, com operações que acabaram com quase todos os morros limítrofes, transformaram a maioria das suas praias

2 Um dos exemplos mais importantes dessa marca da cidade foi a revolta de 1660, conhecida como Bernarda ou Revolta da Cachaça. Foi motivada pelo aumento excessivo dos impostos sobre a aguardente, o que gerou a oposição dos colonos ao governo de Salvador Correa de Sá, que ao final acabou deposto pela corte. 
urbanas, perfuraram túneis, e ademais incluíram a plantação artificial da sua floresta tropical; e o resultado foi de tal ordem que, paradoxalmente, a cidade é tida como exemplo de adaptação à natureza, e não, como realmente é: natureza construída (Andreatta, 2006, p. 20).

A principal imagem da cidade do Rio de Janeiro é desde há muito tempo a imagem da sua natureza, expressa na beleza dos seus morros, das encostas verdes, das suas lagoas, das curvas da Baía de Guanabara e de Copacabana. O movimento paradoxal apontado por Verena Andreatta se explica quando percebemos que é justamente no momento em que a cidade passa a ser mais valorizada como natureza que ela vive suas mais profundas transformações, inclusive no sentido de aperfeiçoar a beleza primitiva. Fazem descer morros, pintam o verde, acentuam as curvas, e a herança que o século XX nos deixa é a da natureza planejada, que sofreu intervençóes, influenciada pela cultura e pelo engenho humano. Entretanto, antes de se tornar a natureza civilizada que já não guarda as marcas do primitivo, da infância ou da ingenuidade, essa mesma natureza impôs as condições de adaptação à cidade e por isso podemos dizer que o Rio de Janeiro nasceu junto desse embate, que promoveu uma tensão entre avanços e recuos na relação com aqueles que ali se estabeleceram: "tiveram os colonizadores primeiro de construir uma cidade que tinha a sua determinação na natureza, para depois construí-la, se possível, como cidade real e ordenada" (Rodrigues, 2002, p. 18).

A tensão acabou por se tornar um traço específico do temperamento do Rio de Janeiro, herança fincada na sua história desde os primeiros embates enfrentados pelos colonos no momento da sua fundação. Muito embora algumas das especificidades cariocas tenham se transformado ao longo desses cinco séculos, especialmente uma se mantém viva até os dias de hoje: o Rio de Janeiro é uma cidade de luta e de tensão e essa experiência se de- 
senrola desde o âmbito do corpo da cidade até o âmbito das ideias que circulam por ela e que conformam a persona desse espírito carioca. Compreendido isto, buscamos avançar no campo de reflexão sobre a cidade do Rio de Janeiro, com o objetivo de colocar a história da cidade e da sua cultura urbana em questão e, assim, observar com quais condições e heranças o Rio de Janeiro adentra o século XX, momento em que ele se reconfigurou para dar-se a ver aos estrangeiros; e de analisar como as mudanças vividas pela cidade nas primeiras décadas do século XX transformaram inclusive sua natureza turística, que antes estava identificada com o centro e as suas sociabilidades e depois passou a estar identificada com os bairros atlânticos da zona sul e aos lazeres praianos.

\section{A cidade em diálogo: o Rio de Janeiro e a sua historicidade}

Dentre todas as cidades brasileiras, por que é o Rio de Janeiro aquela que ainda hoje atrai mais olhares, motivados pelos mais distintos interesses? Diferente do que muitos podem pensar, não está na beleza singular da cidade a explicação para tanta atenção dedicada a ela. O Rio de Janeiro foi a capital política do Brasil entre 1763 e 1960, tendo vivido ao longo desses anos diferentes situações políticas: capital da colônia, capital do Império português, capital do Império brasileiro e capital da República do Brasil. Salvador e Brasília, respectivamente capitais antes e depois do Rio, viveram a experiência de terem suas imagens associadas diretamente ao país, justamente porque ali estava centralizado o poder político de onde se governava todo o território. De forma muito particular, a cidade do Rio de Janeiro, antes mesmo de se tornar o centro político do país, já exercia um papel capital perante as províncias do sudeste e sul brasileiros. Adiante, observaremos como a historiografia da cidade do Rio de Janeiro trata essa questão.

A onda de megaeventos - Rio +20 (2012), Jornada Mundial da Juventude (2013), Copa do Mundo (2014) e Jogos Olím- 
picos (2016) - que o Rio de Janeiro vem enfrentando nos últimos anos tornou ainda mais viva a relação entre a cidade e a nação brasileira. Em 2011, ano que antecedeu a implementação dessa renovação do espírito da cidade que já se preparava para os megaeventos, o governo do estado do Rio de Janeiro lançou uma campanha nos vários meios de comunicação: "Rio de Janeiro, marca registrada do Brasil". A campanha, destinada principalmente aos empresários do estado, visava atrelar à imagem dos seus produtos a imagem do Rio de Janeiro. A marca "RJ" ofereceria de uma só vez a garantia de que o produto é brasileiro - feito no Brasil ou made in Brazil - e de que possui as qualidades da cidade e do estado do Rio de Janeiro - alegria, energia e paixão -, conceitos a partir dos quais se construiu a campanha publicitária. Esforços como este confirmam o propósito do poder público de relacionar os megaeventos à figura do país por meio do espaço metonímico que a cidade assume. Esse modo de olhar e pensar a cidade, entretanto, não é exclusividade das esferas públicas, mas está e esteve presente nos trabalhos acadêmicos que se dedicaram a investigar a história da cidade, bem como no imaginário da sociedade carioca, que se percebe como aquela que melhor sintetiza a cultura brasileira. A historiadora Barbara Freitag nos dá um exemplo desse modo de interpretar a cidade:

Como em 2014 o Brasil vai sediar a Copa do Mundo de Futebol, dando destaque ao Rio de Janeiro, futura sede das Olimpíadas de 2016, a antiga capital agora tem a chance única de mostrar seu potencial cultural e histórico para resgatar sua 'capitalidade', compreendida como aquele atributo que certas cidades têm de construir a síntese e a caixa de ressonância de sua nação, ainda que não sejam capitais políticas (2009, p. 26).

A partir dessa questão, ainda mais acesa contemporaneamente, o artigo "Em algum lugar do passado: cultura e história na 
cidade do Rio de Janeiro", de Antonio Edmilson Martins Rodrigues, ganha um renovado fôlego ao se posicionar na contramão do cânone entronizado por aqueles que só observam a cidade a partir dos limites da nação. Ao perceber que nas últimas décadas o Rio de Janeiro esteve em voga nos estudos acadêmicos, o autor se lança numa revisão dos trabalhos de pesquisa sobre o tema, tendo como norte o objetivo de "encontrar elementos que pudessem acentuar a identidade da cidade e valorizar um espírito carioca que fugia por entre os dedos dos pesquisadores" (2002, p. 13). Metodologicamente, a opção do historiador é promover uma aproximação entre literatura e história para nessa interface desenvolver as chaves de interpretação sobre a cultura urbana carioca. Do lado da história, uma das preocupações principais era "resgatar a memória histórica da cidade e descrever a construção da esfera de poder e da cultura" (2002, p. 14), o que foi motivado pelo fato de sempre se associar o início do processo de modernização do Brasil com o início do processo de modernização da cidade, como se ela fosse uma espécie de microcosmo da nação, de modo que qualquer interpretação sobre ela estaria se remetendo simultaneamente a uma interpretação sobre o Brasil. A segunda principal preocupação é

utilizar todos os resultados para fundamentar a ideia de que a modernidade carioca se constituiu numa nova fundação do Brasil, partindo da condução política do Rio de Janeiro, caixa de ressonância da política nacional. $\mathrm{O}$ equívoco dessa segunda preocupação está em estabelecer uma coincidência entre o lugar onde se tomam as decisões e o alcance das mesmas, tanto no sentido de sua produção como no de sua aplicação (2002, p. 14).

A aproximação com a literatura se dá por motivações relacionadas aos argumentos citados justamente porque a literatura brasileira no século XIX se construiu sobre o conjunto de valores vinculados à nação. "Não, há, no limite, uma literatura, há uma 
história feita através da literatura" (2002, p. 15), o que contribuiu para aumentar a confusão entre os temas particulares à cidade e os temas propriamente brasileiros. O discurso literário e histórico desde o século XIX até a virada para o século XX no Brasil estava marcado pela necessidade de conformar uma unidade de narrativa, um ideal de hegemonia, que

esconde tudo que pode aparecer como conflito, estabelecendo o primado da ordem como aquele que, exemplarmente, está constituído pela cidade-capital. [...] A cidade do Rio de Janeiro, durante esse período, veicula a imagem de progresso e conciliação, fazendo com que acorram para ela todos os acontecimentos de peso histórico, ou seja, aqueles que determinam mudanças (2002, p. 15).

Entretanto, a literatura não se resumiu a isso, oferecendo por dentro dela uma crítica a esse movimento que se pretendia a única forma de construir sentido, apresentando a tensão existente entre uma literatura brasileira e outra nacional; ou seja, uma literatura que conseguisse conjugar valores locais e universais simultaneamente e outra que se inspirasse e limitasse exclusivamente nos fatos nacionais.

Assim, Rodrigues lança seu olhar sobre o Rio de Janeiro observando como a cidade, mais do que mero palco no qual se encenam ideias sobre política e cultura, foi o lugar em que essas ideias foram fomentadas e entraram em disputa, fazendo da literatura, frequentemente, o seu campo de batalha. A cidade do Rio de Janeiro como corpo e espírito, por vezes, representava o lugar de releitura daquele ideal de hegemonia associado à nação, mas, por outras, apresentava as fendas próprias àquele ideal, mostrando como a cidade, e também a literatura e a história, na tentativa de criar sentido para si, se envolvem numa tensão paradoxal entre a 
observação das heterogeneidades e a persistência na construção de modelos homogêneos.

No segundo movimento do artigo, vê-se a construção de um percurso que parte do momento da fundação da cidade no século XVI e segue até o século XX investigando as identidades que o Rio construiu para si ao longo do tempo. Dentre as mais importantes singularidades, seu caráter autônomo foi um dos principais condicionantes para que o Rio de Janeiro viesse a assumir nos séculos subsequentes o papel central na história política do país.

A autonomia de que fala o historiador se justifica pelo fato de o Rio de Janeiro ter sido uma cidade de colonos aberta para o mundo, de modo que não se limitou a um porto ou a uma feitoria. Por causa da sua vocação mercantil, não obedecia ao exclusivo português, permitindo-se fazer comércio com todos que passassem por ela, o que a tornou cosmopolita. Além disso, vinculou-se à produção agrícola, o que dinamizava o comércio de exportação e conformava uma região de abastecimento: "Crescimento urbano, aumento da riqueza mercantil e estabelecimento da expansão promotora do desenvolvimento de uma área de abastecimento da cidade [...] aumentaram a sua autonomia, pois a cidade passava a produzir o que consumia" (2002, p. 19).

Portanto, a autonomia e a capitalidade compõem as principais identidades exploradas pelo autor. O conceito de capitalidade, entretanto, pode ser apresentado a partir de diferentes versóes, sendo as principais aquelas que: associam seu incremento da capitalidade à crescente associação entre cidade e nação; ou compreendem a capitalidade como "a condição de ser um centro articulador de políticas que, no limite, assumia a qualidade de vanguarda no processo de estruturação dos interesses dos colonos" (2002, p. 18). Para Barbara Freitag, no trecho supracitado, é o primeiro sentido o que se anuncia; já para Rodrigues, é o segundo sentido que melhor explica essa importante singularidade da cidade do Rio de Janeiro. Os dois entendimentos se filiam e derivam da re- 
flexão de Giulio Carlo Argan (2004, p. 71) sobre o aparecimento das cidades-capitais, fenômeno vinculado na Europa à consolidação das monarquias absolutistas. A centralização dos poderes e a sua representatividade em um espaço específico conferiram a certas cidades a qualidade de serem simultaneamente capitais desses Estados unificados. O historiador italiano, contudo, adverte que tal função representativa levava as cidades-capitais a terem o seu caráter municipal fragilizado. O Rio de Janeiro, antes mesmo de se tornar uma cidade-capital, já exercia uma função representativa importante, resultado da organização dos interesses dos colonos que ocuparam a cidade e contribuíram para que, por meio da sua vocação mercantil, ela se tornasse mais autônoma do que outras regiōes do território colonial. Isso significa dizer que no Rio de Janeiro dos séculos XVI, XVII e XVIII houve uma experiência autônoma não apenas no âmbito econômico, mas também no âmbito político, de modo que os colonos não se sentiam representados pela Coroa e, por meio do governo dos interesses específicos da cidade, especialmente na Câmara Municipal, se tornaram um modelo a ser seguido pelas províncias, mais próximas, o que, com o passar do tempo, ofereceu um crescente risco à hegemonia da metrópole. A capacidade de se autogerir e influenciar as demais províncias, associada ao enriquecimento de colonos envolvidos com a extração e o comércio de ouro - que vinha das Minas Gerais e era escoado pelo porto carioca -, justificou a necessidade de maior controle fiscal e político da cidade do Rio de Janeiro, fazendo com que a transferência da capital de São Salvador para o Rio ocorresse em 1763.

Este foi o primeiro golpe na autonomia e na capitalidade do Rio de Janeiro, que se viu a partir de então "limitada em sua ação pela presença da Coroa portuguesa" (Rodrigues, 2002, p. 22). A presença das instituiçóes metropolitanas aumentou significativamente a fiscalização sobre os colonos e a identificação com Portugal, de modo que a cidade não exercia mais o mesmo papel 
de antes em relação às demais províncias, que passaram, inclusive, a olhar para o Rio com desconfiança. O segundo golpe sobre a sua capitalidade 3 foi lançado com a transferência da corte portuguesa para a cidade em 1808. Logo depois daquele momento, o Rio de Janeiro tornar-se-ia, mais do que a capital do Brasil, a capital de um império transatlântico. $\mathrm{Na}$ viagem para o Brasil, o príncipe regente não foi acompanhado apenas da sua mulher, Carlota Joaquina, seus nove filhos e alguns membros da corte; o embarque naquele novembro de 1807, em Lisboa, não significava apenas a retirada estratégica da família real de Portugal por causa da ameaça francesa, mas, além disso, "era, sim, a sede do Estado português que mudava de endereço, com seu aparelho administrativo e burocrático, seu tesouro, suas repartiçōes, secretarias, tribunais, seus arquivos e funcionários" (Schwarcz, 2002, pp. 210-1). Tudo isso justifica o fato de naquele momento o Rio ser apelidado de Nova Lisboa (Barra, 2008, p. 121).

Na passagem do século XVIII para o XIX, o Rio de Janeiro sente, em um intervalo de menos de cinquenta anos, o peso de representar a colônia e a metrópole. No século seguinte, a cidade sentiria o peso da República brasileira, que, em oposição ao passado colonial e imperial, se queria moderna e atualizada de acordo com os modelos de progresso disponíveis nos Estados Unidos e na Europa.

Nem cidade moderna nem mais uma cidade colonial. Diferentemente das capitais europeias, diante da modernidade provocada pelo desenvolvimento de estruturas de produção e consumo capitalistas, o que ocorreu na cidade do Rio de Janeiro, na passa-

3 Entendemos que, neste momento histórico, houve um deslocamento do conceito de capitalidade para um de seus elementos possíveis, a centralidade, que vem a ser "a propriedade de uma cidade ser o centro pelo qual devem passar os principais acontecimentos políticos e culturais de um país. Esta qualidade dispensa, ainda que não exclua, a condição de capital" (Azevedo, 2002, p. 17). 
gem do século XIX ao século XX, foi a adaptação da cidade aprisionada a uma nova etapa do desenvolvimento da nação, agora republicana (Rodrigues, 2002, p. 25).

A belle époque carioca, de acordo com Rodrigues, esteve marcada, em parte, por uma artificialidade oriunda da incorporação dos modelos externos sem que estes fossem completamente traduzidos pela tradição. A necessidade de embelezar a cidade e de adequá-la a projetos de desenvolvimento e a resultados modernos promoveu ainda mais dois movimentos que já eram anteriores ao século XX: o primeiro deles se relacionava à ideia de que o Rio de Janeiro se tornava a vitrine do Brasil; e o segundo deixava latentes as contradições existentes na cidade, que deveriam ter sido superadas com a modernização, mas, ao contrário, tornaram-se ainda mais evidentes por causa da tentativa de homogeneização do espaço.

Margarida de Souza Neves, com o propósito de analisar as primeiras décadas republicanas no Brasil, observa a existência de dois cenários distintos e ao mesmo tempo intrínsecos, que conferem um caráter próprio à gênese da República brasileira. Alternam-se no palco, sem desprezar os rastros deixados pelo seu oposto, "a modorra da vida do interior" (2003, p. 16), que se apresentava como o lugar de onde se fazia política, e "a vida vertiginosa do Rio de Janeiro" (2003, p. 16), que deveria ser esvaziada dos debates públicos. A historiadora esclarece:

Ao poder federal competia, despolitizada a capital federal e mantidas sob rédea curta as multidões das cidades, governar os ventos políticos para que não se embaraçassem os fios que uniam os diferentes interesses políticos e não se rompesse o frágil, complexo e eficiente equilíbrio sobre o qual repousava a República. Esse era o segredo da ordem, que, cada vez mais, era apresentada como precondição do progresso (2003, p. 40). 
O século XIX havia reorganizado o mundo de acordo com os valores repensados no âmbito dos avanços tecnológicos e das mudanças geradas a partir de então na sensação de passagem do tempo. As naçôes, desse modo, passaram a ocupar um lugar na linha do tempo da história linear e evolutiva, considerando os traços de desenvolvimento a partir de duas categorias: o avanço e o atraso. $\mathrm{O}$ caso brasileiro tomava um lugar mais atrás nessa linha do tempo, que está mais preocupada em avaliar os estados do que os processos de desenvolvimento em que se encontra cada nação. De acordo com Margarida de Souza Neves, "o problema da concepção evolucionista e linear da história reside em tratar as diferenças como se fossem desigualdades" (2003, p. 23).

Apesar do problema apontado, era justamente essa estrutura de pensamento que vigorava na passagem do século XIX para o século XX no Brasil. Dessa maneira, o país precisava se moldar de acordo com os padróes de progresso material e de civilidade, fossem eles importados do continente europeu ou da América do Norte. A cidade, nesse contexto, se torna o lugar privilegiado de representação das condiçōes ideais de civilidade. Mais do que promover a mudança, é seu atributo expressar essas mudanças. As "duas portas da cidade colonial", apresentadas por Ilmar de Mattos (2002, p. 82), continuam a fazer da cidade-capital uma espécie de dobradiça, investida de uma dupla relação com o interior e o exterior da cidade e do país. De fora, a cidade-capital recebe os sinais cosmopolitas que chegam pelo porto, sua porta de entrada, e alcançam o interior do país. Entretanto, como bem observa Sérgio Barra (2008, p. 112), a cidade vertiginosa do Rio de Janeiro não é apenas o lugar por meio do qual se aprende sobre a civilização europeia; mais precisamente, é ali que tal civilização se expressa.

O Rio de Janeiro assume um papel simbólico como cidade-capital que justificava a reforma urbana, apesar do esvaziamento do potencial político da cidade. A reforma devia fazer acreditar que 
o Brasil - metonimizado na cidade-capital - havia ingressado na era do progresso e da civilização (Neves, 2003, p. 40).

Está justamente na relação dialética entre os dois cenários a explicação para a sustentação de cada uma das partes: os estados figuravam como a realidade de onde se elaborava a direção do governo monopolizada por grupos bem hierarquizados; do outro lado da mesma moeda estava a cidade-capital que legitimava o presente reformador em nome de um projeto ideal ou de um sonho comum que deveria reunir a nação em uníssono.

Ainda na mesma órbita de interpretação, pode-se destacar a importância de Nicolau Sevcenko e seu livro Literatura como missão: tensôes sociais e criação cultural na Primeira República. No tocante a esse capítulo da história da cidade, é relevante refazer os percursos de como o autor se volta para as motivaçóes que desencadearam as reformas vividas no Rio de Janeiro durante o governo do presidente Rodrigues Alves. Simultaneamente, Nicolau Sevcenko (2003, p. 64) investe numa análise do grupo responsável por imprimir uma direção ao governo brasileiro -, a chamada "República dos Conselheiros" -, que deveria restaurar a imagem conservadora e rigorosa herdada dos tempos de Império e, ao mesmo tempo, conciliá-la com os interesses dos cafeicultores e das demandas internacionais.

Um ponto importante de aproximação entre Nicolau Sevcenko e Margarida de Souza Neves pode ser observado no seguinte trecho, que aponta uma ambiguidade constitutiva da Primeira República:

Resultava que a pretendida composição de um Estado-nação moderno no Rio de Janeiro só se tornava viável por meio da sustentação, por cooptação, proporcionada pelas estruturas e forças sociais e políticas tradicionais do interior do país (coronelismo, capanguismo, voto de cabresto, voto de bico de pena etc.), mais 
do que nunca interessadas em tirar partido do volume de riquezas e oportunidades condensadas pelo governo central. O aspirado estabelecimento do regime do progresso e da racionalidade seguia, assim, numa marcha arrastada e entorpecida pela ação corruptora da estagnação e da irracionalidade (Sevcenko, 2003, p. 72).

Dessa forma, a marcha para o progresso trazia nela mesma uma mácula de atraso que era a sua própria força promotora. Nesse sentido, embora o salto de uma condição de atraso para outra de avanço fosse norteado por determinado modelo de civilização, a Primeira República caminhava com os pés viciados pelo modo arcaico de lidar com as questões de ordem pública e com os olhos focados num padrão estrangeiro de desenvolvimento.

Havia uma necessidade imperiosa de ajustar ao menos a capital brasileira aos novos tempos. As características coloniais ainda presentes na trama da urbs e nos modos de estar na cidade destoavam em absoluto das demandas modernas, fossem elas da esfera política, econômica ou cultural. Era preciso introduzir na capital o vírus da modernização para que ele contaminasse todo o Rio de Janeiro e então se tornasse a mais adequada expressão da nova realidade que se queria alcançar em todo o país, em cujo coração eram muitos os males diagnosticados:

$\mathrm{O}$ antigo cais não permitia que atracassem os navios de maior calado que predominavam então, obrigando a um sistema lento e dispendioso de transbordo. As ruelas estreitas, recurvas em declive, típicas de uma cidade colonial, dificultavam a conexão entre o terminal portuário, os troncos ferroviários e a rede de armazéns e estabelecimentos do comércio de atacado e varejo da cidade. As áreas pantanosas fazem da febre tifoide, do impaludismo, da varíola, da febre amarela endemias inextirpáveis (Sevcenko, 2003, p. 41). 
Os autores se dividem, de modo geral, entre aqueles que verificam a maior preocupação do governo com a expansão da cidade e aqueles que observam a maior preocupação com o saneamento público. De um modo ou de outro, ambos os discursos se fertilizam no terreno dos debates sobre um projeto de civilização para a cidade. Nesse sentido, o que se observa é que essas disputas políticas serviram de alimento para o volume que o projeto reformador incorporou.

Segundo Sevcenko, a capital precisava se livrar da imagem de "insalubre e insegura" para que fosse possível captar o maior número de recursos, investimentos, técnicas e mão de obra advindos de fora do país. Era preciso que o país, por meio da sua capital, se apresentasse com alguma credibilidade para que pudesse compartilhar das riquezas que circulavam pelo mundo civilizado. A transformação visando ao progresso deveria ser total, alcançando o "espaço público, o modo de vida e a mentalidade do carioca” (2003, p. 43). Além disso, deveria envolver toda a sociedade para que o novo estado fosse alcançado sem o risco de qualquer dissensão. Para tanto, quatro foram os princípios fundamentais que serviram de esteio para a transformação da capital, de acordo com o autor:

A condenação dos hábitos e dos costumes ligados pela memória à sociedade tradicional; a negação de todo e qualquer elemento de cultura popular que pudesse macular a imagem civilizada da sociedade dominante; uma política rigorosa de expulsão dos grupos populares da área central da cidade que será praticamente isolada para o desfrute exclusivo das camadas aburguesadas; e um cosmopolitismo agressivo, profundamente identificado com a vida parisiense (2003, p. 43).

Durante o Império, a linha evolutiva da civilização brasileira não excluía o passado colonial porque encontrava nele o 
elemento branco que justificava a presença do Brasil no concerto das nações que compartilhavam um ideal de progresso. Em oposição a isso, a República enxergou em qualquer herança colonial, branca ou não, uma prova que atestava o atraso. Como apresenta Sevcenko e outros autores antes citados, o novo momento aponta "um desejo de ser estrangeiro" (Sevcenko, 2003, p. 51), em oposição à preocupação oitocentista com a formação de uma ideia de povo brasileiro. Feito dessa forma, o risco que se correu dizia respeito à dificuldade de se traduzir a modernização a partir de uma tradição, porque esta mesma se via negligenciada pela direção dos novos tempos.

Em um diálogo muito próximo com o historiador Antonio Edmilson Martins Rodrigues, o artigo "A reforma Pereira Passos: uma tentativa de integração urbana", de André Nunes de Azevedo, busca esclarecer como, sob a notoriedade criada em torno do nome e da gestão Pereira Passos, na realidade, era possível distinguir projetos muito distintos para a cidade. Azevedo elucida a questão afirmando que a produção de alguns historiadores sobre a primeira década do século XX no Rio de Janeiro avaliou os anos entre 1903 e 1906 "como um bloco monolítico no cumprimento do intuito de excluir as camadas populares do centro da cidade, em uma verdadeira trama urdida pela burguesia brasileira e orquestrada pelo prefeito Pereira Passos", de modo que

obras como as de Jaime Larry Benchimol, Lia de Aquino Carvalho, Maurício de Abreu, Niemeyer Lamarão e Oswaldo Porto Rocha respondiam ao apelo à redenção da cidade do Rio de Janeiro, uma urbe historicamente marcada pela presença do Estado e de suas ações autoritárias no seu espaço urbano. Esses trabalhos procuravam denunciar a associação do grande capital privado com o Estado brasileiro no início do século XX, a fim de aburguesar o espaço urbano em detrimento das camadas populares (2002, p. 40). 
Segundo André Azevedo, o presidente Rodrigues Alves deixava claro já no seu discurso de posse os intuitos em relação ao Rio de Janeiro, então capital da República. A reforma urbana anunciada já nesse momento tinha como principal objetivo melhorar a imagem da cidade, sobretudo para o exterior, observada como vitrine do país, com a finalidade de dinamizar a economia, que a essa altura dependia do bom funcionamento do fluxo portuário. Fosse com o pretexto de estimular a imigração de estrangeiros que servissem de mão de obra em substituição aos escravos, ou com o interesse de aumentar a arrecadação fiscal por meio das importações feitas pelo porto da cidade do Rio de Janeiro, ${ }^{4}$ "na visão de reforma de Rodrigues Alves, a modernização do porto era concebida como a obra de maior relevância. As demais foram concebidas em função desta, pensada como o centro do plano de intervenção urbana federal" (2002, p. 41).

Entretanto, os problemas da cidade não se restringiam ao porto arcaico, que tinha como uma de suas características um sistema de transbordo demorado e custoso porque obrigava que os navios estrangeiros de grande calado atracassem distante do cais graças aos limites de profundidade, fazendo com que tanto as mercadorias como os passageiros tivessem de ser transferidos para barcos menores para que chegassem a terra. Além disso, a cidade

${ }^{4}$ Azevedo explica, em seu artigo "A reforma Pereira Passos: uma tentativa de integração urbana", que "tal reforma jogava um papel decisivo nos planos de equilíbrio orçamentário da União, pois a constituição republicana previu a sustentação do equilíbrio fiscal da Federação brasileira pelo artifício de conceder aos estados o direito à captação dos impostos sobre as suas exportaçóes, ao passo que à União caberia a arrecadação dos impostos sobre as importaçôes. Como na época o Rio de Janeiro era o principal centro consumidor de produtos importados, a ampliação do porto da capital e a construção de uma estrutura viária para o escoamento dos seus produtos pela cidade tornavam-se fundamentais na estratégia de saneamento econômico do governo de Rodrigues Alves" (2013, p. 37). 
tinha fama de pestilenta, ${ }^{5}$ de modo que muitos estrangeiros evitavam sair das embarcações e, em casos mais graves, deixava-se inclusive de se fazer acordos comerciais para se evitar o porto carioca, havendo uma fatia importante desse comércio que se dirigia diretamente a Buenos Aires.

Além dos problemas do porto e das doenças, o sistema de distribuição das mercadorias para dentro da cidade estava limitado pela inexistência de avenidas largas que ligassem o porto a pontos estratégicos da cidade. Vale lembrar que as ruas eram estreitas e o trânsito da via ficava interrompido se qualquer veículo tivesse de parar para descarregar mercadorias. Com isso,

associada às obras do porto estavam as aberturas da Avenida do Cais - futura Rodrigues Alves -, da Avenida do Mangue - posteriormente Francisco Bicalho - e da Avenida Central - renomeada em 1912 como Rio Branco. Essas três avenidas foram concebidas para constituir um sistema viário destinado a melhor absorver as atividades de distribuição de mercadorias oriundas do porto. Assim, a Avenida do Cais facilitaria a distribuição comercial para os sentidos norte e oeste da cidade, ao passo que a Avenida Central cumpriria o mesmo, mas para com os sentidos sul e centro da cidade (Azevedo, 2002, p. 39).

De acordo com Azevedo, a reforma do porto se torna uma espécie de ícone do progresso brasileiro, na medida em que a partir dali se daria o desenvolvimento econômico da capital, vista pelos governantes da época como símbolo de todo o país. A integração das três avenidas era fundamental para que a cidade se abrisse para o exterior e fixasse à sua imagem o caráter cosmopolita.

5 A cidade era conhecida como "o túmulo dos estrangeiros" e era foco de doenças como febre amarela, febre tifoide, impaludismo, varíola, peste bubônica e tuberculose. 
Para que a reforma da cidade fosse feita, Rodrigues Alves distribuiu as responsabilidades entre algumas figuras, que acabaram apresentando "intervenções urbanísticas orientadas por sentidos distintos” (2002, p. 70), como veremos:

Logo após a indicação do engenheiro Passos, Rodrigues Alves confere-lhe autonomia para projetar uma reforma urbana para o Rio de Janeiro, facultando-lhe, inclusive, governar os seis primeiros meses de seu quadriênio com a Câmara Municipal fechada. Em paralelo, Rodrigues Alves, por intermédio de seu ministro da Viação e Obras Públicas, Lauro Müller, designa um membro ilustre do Clube de Engenharia, Francisco Bicalho, para modernizar o Porto do Rio de Janeiro e operar uma reestruturação urbana na região portuária da cidade, a fim de permitir um melhor sistema de distribuição das mercadorias do porto pela cidade (2002, p. 36).

Além desses nomes, mais um se somou ao fim do ano de 1903, quando foi aprovado o funcionamento da Comissão Construtora da Avenida Central pelo então ministro da Indústria, Comércio, Viação e Obras Públicas, Lauro Müller, designando Paulo de Frontin, que neste momento era o presidente do Clube de Engenharia, para encabeçar as obras daquela que se tornaria mais tarde o grande ícone das reformas realizadas entre 1903 e 1906: a abertura da Avenida Central.

De acordo com André Azevedo, o projeto de reforma do porto e das vias próximas estava alinhado a uma visão de cidade dos seus mentores - Lauro Müller e Francisco Bicalho -, que tem como principal referência o progresso material e

uma visão mecanicista de cidade, na qual a organização viária da urbe deve dar-se em uma relação de parte com parte, por uma razão funcionalista. De acordo com tal perspectiva, a ordenação viária opera-se de maneira causal, isolando a solução de uma demanda 
urbana da cidade enquanto um todo. Assim, a parte pode ganhar uma relevância maior que o todo integrado da urbe, alcançando ela mesma importância superior ao conjunto urbano, uma vez que ocuparia uma função primordial na cidade, como foi o caso da obra do porto no contexto da reforma urbana federal (2002, p. 45).

Do outro lado da visão mecanicista, de acordo com os argumentos de André Azevedo, estava Pereira Passos, que, através da prefeitura, dirigiu as reformas com base em referências distintas daquelas supracitadas. Apesar de articulados com os projetos mais específicos do governo federal, a atuação de Pereira Passos e do chefe da Comissão da Carta Cadastral, Alfredo Américo de Souza Rangel, esteve direcionada a uma reformulação do sistema viário da cidade, através do prolongamento e/ou alargamento de ruas do centro e da zona sul. Vale ressaltar que, para tanto, foi necessária a demolição de dezenas de trechos na região central da cidade, oferecendo a ela uma intervenção plástica na sua feição arcaica. Para o historiador, é justamente na reelaboração do sistema viário que se pode observar a visão organicista que o prefeito tinha, idealizando a cidade

como um corpus continente de diversos órgãos vitais, no qual é fundamental a ligação destes para o funcionamento harmônico do corpo urbano. Sendo assim, a ideia de integração urbana rege o processo de urbanização, pois a cidade passa a ser vista com suas funções interligadas, uma vez que é percebida como uma totalidade, um verdadeiro organismo que justifica o sentimento de existência dos diversos órgãos interligados que o sustentam (2002, p. 44).

Somada ao traço organicista da visão de Passos sobre a cidade estaria ainda uma concepção culturalista da cidade que, de acordo com André Azevedo, se explica pela tentativa de conjugar a 
necessidade de modernização do espaço urbano e ao mesmo tempo valorizar a sua tradição. Assim, para o prefeito Pereira Passos, mais do que a importância de um local preciso da cidade, como o porto, ou de um âmbito apenas, como o econômico, importava toda a dimensão da cidade e da sua sociedade, compreendidas como um organismo que funciona bem na medida em que pode se articular por dentro, inclusive numa relação com o seu passado histórico.

Entretanto, o que se observa é que no cabo de guerra com o governo federal este tinha mais força política e conseguiu imprimir, muitas das vezes, a prevalência do seu sentido para a capital. Por outro lado, as ações do próprio prefeito Pereira Passos, se colocadas na balança, entre a valorização das tradições e a produção de elementos de modernização, pendiam para a segunda, como é possível verificar pela herança que ele deixou com a sua gestão. Se, por um lado, o prefeito tinha uma postura de respeito em relação aos lugares que haviam se tornado referências da cidade - como é o caso do Morro do Castelo, do edifício da Câmara Municipal, da tentativa de construir o Teatro Municipal onde funcionava o Teatro São Pedro de Alcântara e de integrar a cidade ao mar por meio da Avenida Beira Mar -, por outro, a perseguição às vacas leiteiras, aos ambulantes, aos quiosques, aos descamisados que andavam na rua, ao entrudo, além da demolição de vários edifícios de arquitetura colonial, representam ações de intervenção que rivalizam com algumas heranças e práticas tradicionais da cidade.

Azevedo, portanto, associa a direção das reformas pelas mãos do governo federal a uma preocupação com o progresso material da cidade, enquanto a direção das reformas pela prefeitura se relacionaria mais intimamente com uma valorização da cultura. A concepção de civilização defendida pelo prefeito Pereira Passos "consistia fundamentalmente na manutenção de uma civilidade urbana burguesa [...]; no fomento à atividade estética e cultural, na reverência a um passado e no respeito à lei e à ordem pública estabelecidas pelo Estado através de uma elite política ilustrada” 
(2002, p. 49), da qual o próprio prefeito fazia parte. Pode-se observar um impasse relacionado à reverência à tradição, o qual, de acordo com André Azevedo, o prefeito apresentava em decorrência da sua concepção culturalista da cidade:

Ser civilizado em uma grande cidade seria, sobretudo, enquadrar-se nos códigos burgueses de civilidade, associados a posturas pertinentes ao senso de individualidade, ao reconhecimento da legitimidade do espaço privado e da percepção do espaço público como um espaço que deve ser utilizado a partir da observação às regras estabelecidas por leis. No entanto, tais leis eram fixadas a despeito de elementos da tradição popular da cidade, pois eram feitas pela elite urbana do Rio de Janeiro (2002, p. 50).

Por ter o desenvolvimento de uma civilidade urbana como meta principal, mesmo que este se desse em detrimento da tradição, o prefeito se dedicou a ensinar os padrões de civilização àqueles grupos sociais que não aderiram imediatamente à sua concepção. Então, toma o centro da cidade reformado como o locus privilegiado no sentido de se tornar exemplar. Para tanto, toda a sua dedicação em reformular a rede viária da cidade seria fundamental, uma vez que o trânsito entre diversas regiōes da cidade estaria, a partir de então, facilitado, permitindo que o operário que morasse nos bairros mais afastados pudesse aprender as regras do jogo ao visitar o centro. Mais do que isso, depois dessa iluminação, o operário retornaria para o seu bairro capacitado para inscrever também ali os mesmos padrōes de civilidade que encontrara nas ruas do centro (Azevedo, 2002, p. 52).

Embora a visão organicista do prefeito estivesse confirmada, seu propósito civilizador avançava de tal forma sobre a cidade que ela, como carne e espírito, viu-se num embate que apontava três caminhos: aderir a tal visão de mundo, ou seja, não preservar as diferenças; resistir por meio da manutenção das 
tradições, preservando e recriando espaços dissonantes em relação ao projeto de civilização; ou buscar conjugar as duas coisas, por meio de diferentes leituras da civilização pelas sociabilidades mais tradicionais, de modo que se recusasse o mero simulacro, mas se estimulasse a assimilação costurada por dentro das especificidades cariocas.

\section{Rio de Janeiro: de cidade das letras à cidade maravilhosa}

O Rio de Janeiro viveu na virada do século XIX para o século XX uma experiência literária bastante fecunda, associada a uma vida cultural efervescente. $\mathrm{Na}$ esfera política, a cidade havia perdido ao longo dos séculos anteriores a capacidade de se autogerir de acordo com as demandas e anseios da sua população, como vimos no item anterior. Essa condição se estabeleceu na medida em que a cidade paulatinamente perdeu seu caráter municipal para assumir o papel de capital do país. A concentração dos órgãos públicos e a centralidade política que a cidade-capital passa a ter em âmbito nacional simultaneamente enfraqueceram as redes de direção política que emergiam dos próprios cariocas e fortaleceram a imagem de lugar ideal não apenas para os representantes oficiais como para intelectuais e literatos que circulavam pelo Rio. Desse modo, o Rio de Janeiro, capital da colônia, da corte e da República, transformou-se pouco a pouco no palco em que as decisões políticas eram tomadas e de onde eram dirigidas. Seu lugar simbólico, então associado a um cenário, permitiu que entrassem em cena os atores políticos vinculados a outras regiôes brasileiras, reduzindo a atmosfera carioca a um ambiente onde os que faziam política não eram propriamente os mesmos cariocas que pensavam os rumos políticos da nação. A observância dessa lacuna pelos intelectuais serviu de estímulo para que eles mesmos participassem da vida pública carioca a partir, entretanto, de um outro ambiente de debates: a literatura. 
A centralidade da cidade do Rio de Janeiro, ao mesmo tempo que possibilitava a concentração de tantos literatos, também estimulava que a própria cidade se tornasse o motivo da escrita deles. Desde a geração da década de 1870 até o início dos anos 1920, a cidade do Rio de Janeiro foi o lugar em que se concentraram o maior número de literatos, que constituíram ao longo dos tempos os clássicos da literatura brasileira. Muitos deles se envolveram em questôes nacionais; outros tiveram seu nome vinculado pela fortuna crítica ao Brasil; houve ainda os que escrevendo sobre a capital federal almejassem mimetizar o país como um todo; e também os que escrevendo sobre o Rio de Janeiro não tivessem outro fim senão refletir sobre as tensões com as quais a cidade-capital estava envolvida durante as primeiras décadas do período republicano.

Esse momento em que a literatura brasileira se questionava a respeito das suas cores locais, sua brasilidade, suas relaçóes com a conformação de um caráter nacional e ainda com a universalidade dos seus traços foi também o momento de decisivo desenvolvimento da imprensa nacional, especialmente a da capital federal. Muitos dos literatos brasileiros mais citados desde então - José de Alencar, Machado de Assis, Olavo Bilac - estiveram envolvidos como editores, redatores, colunistas de muitos dos periódicos que circularam no Rio de Janeiro entre 1870 e 1920. Diversos clássicos posteriormente publicados pelas editoras foram primeiro publicados inteiramente nos folhetins.

De modo geral, os literatos faziam do envolvimento com o jornalismo a oportunidade de um ganho de vida mais estável, tendo em vista que as publicaçóes pelas editoras estavam submetidas a uma sazonalidade e a uma incerteza muito grandes. $\mathrm{O}$ trabalho em jornais e o serviço público foram os principais aliados para que muitos literatos pudessem ganhar um soldo e, então, investir na literatura. Assim, era bastante comum que os temas mais atuais e relevantes no âmbito da política, da filosofia e da cultura estivessem presentes nas colunas dos periódicos por meio 
da pena dos escritores brasileiros. Por um lado, a imprensa acabou popularizando as letras entre os mais variados leitores; por outro, a literatura teve muitas vezes de se adaptar às características específicas do suporte jornalístico. As crônicas, por exemplo, ganham a cena como um dos gêneros literários mais recorrentes entre os literatos desse período por se tratar de um tipo de escrita muito associado à condição transitória do tempo e, portanto, servir como um excelente registro da modernidade carioca. Elas guardam a qualidade de contribuir para uma leitura mais breve e que acompanha, em certa medida, a aceleração do tempo percebida entre as pessoas na virada do século XIX para o XX. A vida moderna nervosa ganha, assim, um gênero literário associado a ela porque conjuga em si mesmo a condição da aceleração e da transitoriedade do tempo histórico tal como ele era sentido e percebido pelas pessoas àquela altura.

É um traço das crônicas que seus temas representem o cotidiano e as questóes diárias; contudo, não é raro que temas universais apareçam nas entrelinhas do tratamento dado às questôes mais ordinárias. Dessa forma, algumas delas sinalizavam as reflexões mais profundas de alguns literatos, como é o caso de João do Rio, pseudônimo de Paulo Barreto, que dedicou a vida a escrever sobre o Rio de Janeiro e a descortinar a alma das ruas, a psicologia da cidade, as antropologias das religiōes silenciadas na capital, entre outras investidas que ocuparam a vida de um dos principais cronistas brasileiros até o seu falecimento em 1921. Paulo Barreto fez passagens em mais de uma dezena de periódicos, entre eles: A Cidade do Rio, O Dia, Correio Mercantil, O Tagarela, O Coió, Gazeta de Notícias, Kosmos, O Paiz, O Comércio de São Paulo, A Noite, A Notícia, A Ilustração Brasileira, El Diario, A Revista da Semana, A Pátria. No caso dele, literatura e jornalismo caminharam juntos, de modo que ele se dedicava por muitas horas às redações dos jornais, sobretudo se ocupasse cargos de chefia. $\mathrm{O}$ tempo que passava nas ruas era dedicado a nutrição do seu espírito, buscando ideias, motes, temas, 
perseguindo por meio da pesquisa in loco as almas que compunham a cidade. Toda a agitação vivida por ele cotidianamente, entre as ruas e as redações, alimentava a sua verve incansável de cronista. No jornal $A$ Gazeta de Notícias, escreveu, com o pseudônimo X., a coluna A Cidade, entre os anos de 1903 e 1904, quando o Rio de Janeiro enfrentava os primeiros sinais de mudança por causa das reformas urbanas, durante a gestão de Pereira Passos. Possivelmente, foi o jogo entre despretensão e profundidade que marcou tão especialmente as crônicas de João do Rio e as de muitos outros que a elas se dedicaram (Costa, 2011, pp. 63-4). A partir do momento em que transformaram a crônica no seu modo particular de comunicar, os cronistas refiguraram a cidade que tinham como tema em suas linhas em uma cidade de letras. ${ }^{6}$

Um dos momentos históricos mais largamente pesquisados sobre o Rio de Janeiro é precisamente o início do século XX e as transformaçōes urbanas que a cidade experimentou. A aliança entre governo federal e prefeitura permitiu que o projeto de reformas saísse do papel e alcançasse seus objetivos mais importantes em um intervalo de quatro anos. O nome Pereira Passos é ainda hoje lembrado porque as condições dadas pela direção federal permitiram que as obras fossem levadas a cabo, tendo como resultado uma realização de sucesso, inédita até então na história da cidade. Essas transformações urbanas, entretanto, não se restringem às reformas do porto, às demolições, às construções de novas ruas e avenidas ou à modernização arquitetônica da cidade. As transformaçōes urbanas abarcam todas as mudanças afetadas por processos de modernização, que ora estão relacionados ao progresso material e à presença da tecnologia e ora se vinculam ao

${ }^{6}$ A expressão "cidade das letras" se inspira nos argumentos do historiador uruguaio Angel Rama, e em seu livro $A$ cidade das letras, na medida em que ele observa que os grupos intelectuais - que por vezes coincidem com os grupos dirigentes - são capazes de construir uma cidade que coexiste em relação à cidade real, pois produzem a esfera simbólica da cidade. 
desenvolvimento do espírito e, por conseguinte, à maneira como a sociedade carioca passou a se perceber. A imprensa, por exemplo, estava associada aos dois âmbitos, porque sofreu uma revolução com a chegada de novas técnicas de impressão e porque se tornou o ambiente frequentado pelos intelectuais que pensavam a cidade, lançavam modismos, lapidavam o gosto carioca e opinavam sobre cada momento vivido pela cidade. $A$ cidade das letras era propriamente aquela que escolheu explorar como objeto de observação e interpretação o próprio Rio de Janeiro. Desde a realização de saraus, tertúlias, enquetes, conferências, até a publicação de matérias, colunas, revistas, livros inteiramente dedicados à cidade, o que se via era que os literatos recriaram a cidade real por meio das letras.

A efervescência cultural da cidade do Rio de Janeiro em sua belle époque, muito estimulada a partir das experiências estrangeiras, sobretudo de Paris, transformara o centro da cidade reformado e alguns bairros da zona sul da cidade em espaços de fruição e lazer dos próprios cariocas. Confeitarias, cafés, bares, cabarés, cervejarias, restaurantes, sorveterias, livrarias, teatros e cinemas reanimaram o espírito da cidade, fazendo da rua o lugar de encontros, trocas, flertes, conversas e sociabilidades que não estavam confinados às paredes dos espaços privados, mas, pelo contrário, contaminavam a ambiência e envolviam os cariocas em uma rede simbólica que costurava o imaginário urbano a partir das vivências culturais e dos eventos sociais cotidianos na cidade.

Durante os primeiros anos republicanos, o espírito da cidade poderia ser perfeitamente traduzido pelas letras que pensavam e contavam a vida no Rio de Janeiro. Embora cidade das letras nunca tenha se tornado um epíteto para a cidade do Rio de Janeiro, foi por meio da literatura que o escritor Coelho Neto adjetivou o Rio de Janeiro como cidade maravilhosa. Os contos reunidos em A cidade maravilhosa, livro publicado em 1928, confirmam a estreita relação entre o universo da cultura e o das letras na cidade. 
A expressão, presente depois em nome de programa radialístico e consagrada em marchinha de carnaval, é até hoje o epíteto mais popular do Rio de Janeiro. Surgida em uma ambiência carioca que valorizava sobremaneira as diversōes e lazeres culturais, cidade maravilhosa hoje representa para o senso comum as belezas das paisagens naturais que a cidade possui.

$\mathrm{Na}$ década de 1920, entretanto, já não era exclusivamente o centro da cidade reformado durante a prefeitura de Pereira Passos, seus bulevares abertos, edifícios neoclássicos erguidos e a civilidade burguesa parisiense que impressionavam em uma visita ao Rio de Janeiro. Desde o final do século XIX, com a abertura de túneis e a instalação de novas linhas de bondes, os bairros atlânticos, especialmente Copacabana, vinham se tornando crescentemente as meninas dos olhos dos prefeitos, das construtoras e dos especuladores imobiliários. O discurso higienista e civilizatório encontrava respaldo nos usos e projetos destinados àquela região da cidade, que não era vista como o avesso do progresso, mas como o grau zero, ou seja, o lugar fértil para o desenvolvimento dos projetos de progresso e civilidade (O’Donnell, 2013, p. 32).

Os parâmetros de vanguarda associados à fruição da cultura em espaços fechados - como se via em metrópoles mundo afora - aportaram no Rio de Janeiro ao lado da valorização, não menos civilizada, dos usos para a saúde do corpo e da mente em áreas abertas, como eram as praias quase selvagens dos bairros atlânticos da cidade. Exemplo disso é que um dos caminhos abertos para o arrabalde de Copacabana foi iniciativa de um empreendedor que possuía um hotel destinado ao turismo muito próximo da atual ladeira dos Tabajaras.

Já no século XIX, bairros como Flamengo e Botafogo foram ocupados pela gente abastada que desejava usufruir da amplidão dos terrenos, das brisas marítimas e dos banhos medicinais na Baía de Guanabara. Um dos exemplos mais importantes desse fenômeno é que a família imperial manteve uma casa em Bota- 
fogo, de frente para a baía. Antes da chegada da corte, o Rio se via concentrado e limitado por quatro morros: Morro de Santo Antônio, Morro do Castelo, Morro de São Bento e Morro da Conceição, todos na região do centro da cidade, todos margeados pela Baía de Guanabara. Com a chegada da corte em 1808, muitos incentivos foram dados para estimular a ocupação de outras áreas da cidade, entre elas os bairros da zona sul banhados pela Baía: Glória, Flamengo e Botafogo. Mais uma vez, a expansão e a ocupação da cidade dependiam das relaçóes tensas entre os projetos de cidade ideal civilizada e a natureza, primitiva e selvagem. Assim, ainda sem vencer os morros da cidade, o desenvolvimento seguiu o rumo da orla na estreita faixa entre os morros e a Baía. Não tardou que o desmonte dos morros e a criação de túneis se tornassem uma questão central para os engenheiros e higienistas que comandaram politicamente a cidade a partir do início do século XX. Enquanto isso, as famílias enriquecidas investiam nos bairros próximos à orla, enquanto o interior da cidade - a Tijuca, por exemplo - fazia as vezes de sítio afastado e bucólico.

$\mathrm{O}$ fenômeno do turismo destinado à cura cresceu na segunda metade do século XIX, impulsionado pelos avanços na medicina que apontavam os ares serranos mais puros e os banhos em águas gélidas parceiros no tratamento de diversos males, inclusive psiquiátricos (Urry, 2001, p. 35). A postura em relação aos banhos não era livre como hoje se apresenta; pelo contrário, obedecia a uma prescrição rigorosa dos médicos, que apontavam o melhor horário para o banho, quantos minutos de imersão deveriam transcorrer e em que situações ele deveria ser interrompido. Tantos cuidados exigiam o acompanhamento cada vez mais comum nas estações de banho que se espalharam por Inglaterra e França no século XIX. Embora houvesse muitas distinções entre Bath e Biarritz, os impulsos para o crescimento de estações de banho e balneários como esses partia do mesmo intento de associar alguma distinção social e preocupação com a saúde. 
Entre os anos 1900 e 1930, houve uma mudança cultural notável em relação ao modo como o burguês aproveitaria a vida. Os estereótipos informam alguns dados relevantes: se o burguês de 1900 estava vinculado a hábitos boêmios e notívagos, associados a desordem, bebidas, drogas e promiscuidade sexual; o burguês dos anos 1930 se apresentava com uma postura mais conservadora, por meio de hábitos diurnos e do culto aos esportes. Em certo sentido, os abusos relacionados aos vícios do 1900 abririam espaço para o cultivo de virtudes - tão civilizadas quanto os vícios anteriores - associadas à saúde do corpo e dos organismos (O’Donnell, 2013, p. 161).

No Rio de Janeiro, essa flutuação dos hábitos da vida é bastante visível na maneira como se desenvolveu o bairro de Copacabana. Nos anos 1910, era muito bem visto que os moradores do bairro circulassem pela cidade durante os fins de semana aproveitando os aspectos positivos de morar em um bairro atlântico e de estar a menos de meia hora do centro, onde se poderia usufruir de outra sorte de lazeres. $\mathrm{O}$ traço cosmopolita do crescimento da cidade estava presente justamente na abertura para a circulação, na diversidade de usos que a cidade possuía. O mar, fosse o Atlântico ou o porto na Baía de Guanabara, representava o cosmopolitismo porque era através dele que as trocas culturais se estabeleciam. Em meados dos anos 1920, a postura dos moradores de Copacabana - bem como de Ipanema e Leblon - já era a de demandar uma distinção daquele antigo arrabalde dos demais bairros da cidade, sobretudo os mais populares, valorizando cada vez mais o exercício de afazeres e costumes praianos como dado elementar de status social. A circulação se tornou cada vez mais um atributo dos moradores dos bairros da zona sul respeitados os limites do centro da cidade e a "excentricidade" dos bairros mais populares da zona norte (O’Donnell, 2013, p. 141).

A cidade maravilhosa, de sol e mar, é nos dias de hoje uma imagem vinculada e veiculada exclusivamente aos aspectos posi- 
tivos da vida - ativa e, sobretudo, contemplativa - que se observa pela orla desde a Barra da Tijuca até o centro da cidade. Entre os anos 1900 e 1930, entretanto, ela foi fruto da intervenção da cidade das letras. Não apenas porque o epíteto tenha surgido nos contos de Coelho Neto, literato muito presente na imprensa carioca, mas porque o estilo de vida corrente nos bairros atlânticos não era - como o mar, a praia, os morros - uma natureza. O que se tornou a forma corrente de frequentar as praias foi ensinado ao carioca por meio da coluna "Iracema", na Revista da Semana, entre os anos 1914 e 1917 (O’Donnell, 2013, p. 103). O aprendizado das sociabilidades na praia foi feito a exemplo das experiências de sucesso dos balneários europeus, visando à associação entre a valorização dos atributos naturais dos bairros atlânticos cariocas a uma ocupação suntuosa e elegante.

Se, nas primeiras duas décadas do século XX, o Rio de Janeiro, culturalmente efervescente, especialmente no centro da cidade, era simbolizado pela cidade das letras, a partir dos anos 1920, a ocupação dos bairros atlânticos fez com que pouco a pouco a imagem da cidade se dissociasse do passado vinculado às sociabilidades do centro - cafés, bares, confeitarias, teatros, cinemas - e se deslocasse crescentemente em direção à zona sul e à cultura da vida praiana em meio à paisagem do mar, emoldurado pelas montanhas.

Pode-se dizer que a imagem que se fixou do Rio de Janeiro, findo o século XX, foi a da cidade que se destaca em razão das suas belezas naturais. Freire-Medeiros e Castro são conclusivos ao afirmarem que "o que hoje é percebido como uma 'natureza turística' da cidade é, portanto, apenas um momento de um longo processo de construção cultural, sempre inacabado" (2013, p. 34). Convém observar, portanto, que esse imaginário que paira sobre o Rio de Janeiro é bastante recente e está vinculado a uma série de fatores que tornaram a cidade culturalmente menos vibrante do que ela era cem anos atrás. Por um lado, a literatura foi esvaziada de cronistas dedicados exclusivamente à vida da cidade, de modo que 
os repórteres conhecidos por tematizar o Rio hoje em dia apenas fazem notas, dão pequenas notícias, enquanto aqueles de outrora produziam centenas de crônicas diárias refletindo sobre os mais diversos acontecimentos cotidianos da cidade. Diferente deste, mas ainda no mesmo universo cultural, outro exemplo que podemos citar é da escassez de cinemas, especialmente os cinemas de rua, na cidade do Rio de Janeiro. Bairros como a Tijuca, na zona norte, não possuem hoje nenhum cinema de rua. Entre 1907 e 1997, entretanto, 42 salas de cinema de rua abriram e fecharam no bairro. Este, que já contou com mais de 10 mil assentos em salas de cinema, hoje conta com menos de 2 mil, distribuídos entre seis salas de cinema concentradas em um shopping center. $\mathrm{O}$ cinema Olinda, que funcionou na Praça Sáenz Peña entre 1940 e 1972, somava sozinho 3.500 assentos. Essa desvitalização da cena cultural carioca não é exclusividade da zona norte. Em toda a cidade esse processo se acentuou entre os anos 1980 e 2010, em razão do aumento da violência urbana. Em Copacabana, no ano de 1992, havia 11 cinemas de rua espalhados pelo bairro, restando apenas dois atualmente.

A publicação de guias turísticos sobre o Rio de Janeiro nos ajuda a acompanhar a transformação do modo como a cidade foi vista e apresentada aos visitantes ao longo do último século. Charles Morel e Henrique Morel, através do Guide de l'etoile du sud. La ville de Rio de Janeiro, queriam tornar a cidade conhecida dos europeus. Escrito em português e francês, a primeira edição do guia é de 1897, feita pelo pai, Charles Morel, e a segunda, de 1905, contou com a colaboração do filho, Henrique Morel. Como era costume, o guia trazia uma breve história da cidade e fotografias de alguns políticos da época, como as do prefeito Pereira Passos e as do presidente Rodrigues Alves. Chamam a atenção alguns aspectos muito particulares: a presença de aconselhamento sobre cuidados com a higiene e saúde - como evitar a exposição ao sol, tomar banho frio apenas de manhã ou à noite, não adicionar 
gelo às bebidas, evitar o sereno, sair o mínimo possível à noite, evitar excessos alcoólicos ou de qualquer ordem - e as detalhadas informações sobre os sintomas da febre amarela. Como visto no item anterior, a cidade era considerada pestilenta e fazia apenas um ano que havia sido palco da Revolta da Vacina. Reescrito no calor das reformas urbanas, o guia critica as ruas estreitas e mal pavimentadas do centro da cidade e já previa a mudança do comércio de luxo da Rua do Ouvidor para a Avenida Central, tão logo fosse inaugurada. De acordo com os argumentos higienistas, o guia maldiz também a abundância de morros na cidade porque eles contribuem para a demora no deslocamento de um ponto a outro, tendo em vista que tinham de ser contornados, uma vez que ainda não havia tantos túneis como atualmente. Como foi escrito durante as reformas, o guia alerta que muitas indicações sobre as ruas, especialmente as do centro, poderiam não estar mais de acordo com a realidade quando fossem finalizadas as obras. Como em vários outros guias, livros e catálogos sobre a cidade do Rio de Janeiro, a imagem da Baía de Guanabara e do Pão de Açúcar era a primeira a figurar no Guide de Charles e Henrique Morel. A recorrência de imagens da Baía nos guias estava relacionada ao fato de ser aquele local o ponto de entrada na cidade do Rio de Janeiro, quando a maioria dos visitantes ainda chegava por mar (Castro, 1999, p. 83). Era necessário, portanto, ambientar os turistas com aquilo que primeiro causaria impacto na chegada à cidade e que se faz presente no imaginário dos visitantes e cariocas como uma das mais potentes imagens que simboliza o Rio de Janeiro: a vista da cidade espraiada entre o mar e as montanhas.

Se comparado aos guias atuais, há dois aspectos presentes no Guide de Charles e Henrique Morel que já não estariam presentes da mesma forma. Nas primeiras décadas do século XX, o primeiro passeio indicado ao turista deveria ser feito de bonde e a pé visitando ruas, monumentos e edifícios do centro da cidade. Algumas vezes, o passeio ficava limitado ao centro e, em outras, 
estendia-se aos bairros banhados pela Baía de Guanabara. Hoje, os primeiros passeios indicados aos visitantes são os mirantes do Pão de Açúcar e do Corcovado e as praias dos bairros atlânticos: Copacabana, Ipanema e Leblon. O segundo aspecto diz respeito à organização do mapa turístico da cidade. Hoje em dia, a parte inferior do mapa, de onde começamos a vê-lo, está ocupada pela orla da zona sul, enquanto naquela época era ocupado pelo centro da cidade. Vale sublinhar que os bairros atlânticos sequer apareciam no mapa anexado ao Guide de Charles e Henrique Morel.

$\mathrm{Na}$ ocasião da Exposição Internacional de 1922, que comemorava o centenário da Independência do Brasil, foi publicado o Guia official da exposição, que, além de dados sobre os pavilhões e um mapa de toda a região que a exposição abrangia, servia também como guia turístico, introduzindo o visitante no Rio. Após a gestão do prefeito Pereira Passos, outros prefeitos deram prosseguimento às obras iniciadas na primeira década do século XX, observando os paradigmas higienistas e urbanistas da época. $\mathrm{O}$ prefeito Carlos Sampaio foi exemplo disso, sendo conhecido especialmente pelo desmonte do Morro do Castelo - local de fundação da cidade, fortemente associado ao passado colonial carioca - e pela realização da Exposição Internacional de 1922. O guia, escrito em português, francês e inglês, traz toda sorte de informações turísticas importantes: sugestões de meios de hospedagem - a maioria delas no centro da cidade -, meios de transporte da cidade, agências de viagem especialmente dedicadas a cruzeiros marítimos, endereços de embaixadas, consulados, legações, além de indicaçôes de bares e restaurantes, o que segue sendo comum nos guias contemporâneos. $\mathrm{O}$ guia informa ainda que o Palácio Monroe - construído para ser o pavilhão do Brasil na Exposição Universal de Saint Louis, sendo desmontado e transportado para o Rio de Janeiro para ali ser remontado em 1906 - seria usado como uma espécie de centro de atendimento ao turista, oferecendo serviços de informaçôes, cambio, agenciamento, bem como 
material de propaganda e venda de bilhetes para teatro e afins. Tal como o Guide de Charles e Henrique Morel, a primeira imagem que consta no guia da exposição é uma tomada da Baía de Guanabara com o Pão de Açúcar. Por outro lado, os primeiros passeios pitorescos indicados em 1922 são a subida ao Pão de Açúcar, onde já estava instalado há dez anos o bondinho, e a ida ao Corcovado de trem elétrico. A essa altura, o Corcovado oferecia apenas um panorama da cidade, tendo em vista que o Cristo Redentor seria inaugurado anos depois. De todo modo, os bairros atlânticos ainda não constavam entre os passeios sugeridos, e o centro da cidade figurava ainda como a "menina dos olhos" do carioca.

Nestes últimos vinte anos desde a administração do Prefeito Pereira Passos à administração atual do Prefeito Carlos Sampaio, as grandes obras de higiene e embelezamento converteram a antiga cidade colonial, de ruas estreitas, iluminação deficiente e construções antiquadas, numa metrópole moderna, profusamente iluminada, excelente calçamento de asfalto, construções magníficas e largas avenidas arborizadas e formosos jardins públicos (Guia Official da Exposição, p. 285).

Com esses exemplos, conseguimos observar como a imagem da cidade mudou ao longo dos anos em decorrência de todo tipo de transformações que ela viveu. A mudança da imagem da cidade para os próprios cariocas e para os estrangeiros alterou também a própria experiência turística que se experimentou no Rio de Janeiro ao longo do século XX. Enquanto nas primeiras décadas do século XX os guias destacam a vista da Baía de Guanabara, a visita ao centro e seus monumentos e edifícios, já nas últimas décadas do século XX se observa que o destaque passa a estar nas praias da zona sul e nos mirantes do Pão de Açúcar e do Corcovado. Castro é conclusivo ao afirmar que "não se trata de uma relação de determinação direta, e sim de interação: às vezes muda 
a cidade, muda o turismo; outras vezes, a partir de modificações no mundo do turismo, introduzem-se alterações urbanísticas na cidade" (1999, p. 84). A natureza turística do Rio de Janeiro se viu transformada na medida em que a cidade das letras, sediada no centro, passou a concorrer com a expansão da área urbana e o desenvolvimento dos bairros atlânticos da zona sul, que hoje figuram nos cartôes-postais e simbolizam a principal paisagem da cidade maravilhosa.

\section{Considerações finais}

O Rio de Janeiro conjuga em seu caráter certa singularidade, expressa no espírito do carioca, e certa pluralidade de características, que adquiriu por representar todo o país enquanto capital. Se hoje o visitante encontra na cidade vários dos regionalismos brasileiros, é porque, por muito tempo, ela, como centro da nação, recebeu gente de todos os cantos do país. O Rio correu o risco, com isso, de se despersonalizar e acabar no fim das contas parecendo e representando lugar nenhum. O espírito carioca, entretanto, é dotado de uma característica muito marcante: apropriar-se das coisas, produzindo releituras de tudo o que o alimenta e o inspira. Esse traço garante ao Rio de Janeiro e ao carioca uma relação de autenticidade com tudo que trava contato, mesmo que o elemento em questão seja estranho, estrangeiro. Esse impulso foi necessário quando a cidade, ainda nos séculos XVII e XVIII, já estava aberta ao mundo, fazendo comércio com diferentes países, garantindo sua autonomia e desenvolvendo seu cosmopolitismo.

A partir do momento em que o Rio não mantém mais o seu caráter exclusivamente municipal e passa a exercer as funções de capital, foi necessário que os cariocas resistissem, se não na esfera política, ao menos na intelectual. Desde o século XIX, a literatura foi o espaço encontrado pelos intelectuais que, refletindo sobre a cidade, observavam que no mesmo espaço da cidade-ca- 
pital conviviam vários lugares simbólicos que ora diziam respeito exclusivamente à cidade e ora refletiam a força da centralidade da capital. Essa e outras tensões foram registradas por cronistas que acompanharam os processos de modernização urbana do Rio de Janeiro no início do século XX. A imagem da cidade que se construía na literatura ganhou forma e vigorou como cidade das letras justamente porque efervesciam os encontros culturais e as experiências intelectuais nos mais diversos ambientes do centro da cidade, dos cafés aos teatros. Assim, a cidade maravilhosa era a cidade das letras, a cidade onde o centro e as suas sociabilidades - e não os bairros atlânticos e o lazer ao ar livre - eram destaque entre cariocas e estrangeiros.

$\mathrm{Na}$ medida em que a literatura foi deixando de ser o terreno no qual se construíam as imagens da cidade e o Rio passou a se expandir e a se desenvolver no sentido da zona sul, a expressão cidade maravilhosa ganhou novo significado, que expressa, antes, as belezas naturais relacionadas à paisagem da cidade espraiada entre as montanhas e o mar. A natureza turística do Rio de Janeiro acompanhou essas mudanças e continua a confirmar essa nova visão da cidade, que as últimas décadas do século XX e os primeiros anos do século XXI seguem ratificando.

\section{Referências}

ANDREATTA, Verena. Cidades quadradas, paraísos circulares: os planos urbanisticos do Rio de Janeiro no século XIX. Rio de Janeiro: Mauad X, 2006, 206 p. ARGAN, Giulio Carlo. Imagem e persuasão: ensaios sobre o barroco. São Paulo: Companhia das Letras, 2004, $632 \mathrm{p}$.

AZEVEDO, André Nunes de. "A capitalidade do Rio de Janeiro. Um exercício de reflexão histórica". Anais do Seminário Rio de Janeiro: Capital e Capitalidade. Rio de Janeiro: Departamento Cultural / NAPE / DEPEXT / SR-3 / UERJ, 2002, pp. 45-63.

_ _ "A reforma Pereira Passos: uma tentativa de integração urbana". Revista Rio de Janeiro, Rio de Janeiro, mai.-ago. 2013, n. 10, pp. 35-63. 
BARRA, Sérgio Hamilton da Silva. Entre a corte e a cidade: o Rio de Janeiro no tempo do rei (1808-1821). Rio de Janeiro: José Olympio, 2008.

CASTRO, Celso. "Narrativas e imagens do turismo no Rio de Janeiro". In VELHO, Gilberto (org.). Antropologia urbana: cultura e sociedade no Brasil e em Portugal. Rio de Janeiro: Zahar, 1999, pp. 80-7.

COSTA, Amanda Danelli. Cidade, reformas urbanas e modernidade: o Rio de Janeiro em diálogo com João do Rio e Augusto Malta (tese). PUC-Rio, 2011.

FREIRE-MEDEIROS, Bianca e CASTRO, Celso. "Destino: Cidade Maravilhosa”. In CASTRO, Celso et al. (orgs.). História do turismo no Brasil. Rio de Janeiro: Ed. FGV, 2013, pp. 13-36.

FREITAG, Barbara. Capitais migrantes e poderes peregrinos: o caso do Rio de Janeiro. São Paulo: Papirus, 2009, 400 p.

GUIA OFFICIAL DA EXPOSIÇÃO Internacional do Rio de Janeiro em 1922. Rio de Janeiro: Bureau Official de Informaçōes, 1922, 392 p.

MATTOS, Ilmar R. de. "O Rio de Janeiro e a experiência imperial". In AZEVEDO, André Nunes (org.). Rio de Janeiro: capital e capitalidade. Rio de Janeiro: Departamento Cultural / Nape / DEPEXT / SR-3-UERJ, 2002, pp. 77-86. MOREL, Charles e MOREL, Henrique. Guide de l'etoile du sud. La Ville de Rio de Janeiro. Rio de Janeiro: Edición l'Etoile du Sud, 1905, 159 p.

NEVES, Margarida de Souza. "Os cenários da República. O Brasil na virada do século XIX para o século XX”. In FERREIRA, Jorge e DELGADO, Lucília de Almeida Neves. Brasil republicano: o tempo do liberalismo excludente: da proclamação da República à Revolução de 30. Rio de Janeiro: Civilização Brasileira, 2003, v. 1, pp. 13-44.

O'DONNELL, Julia. A invenção de Copacabana: culturas urbanas e estilos de vida no Rio de Janeiro (1890-1940). Rio de Janeiro: Zahar, 2013, 255 p.

RAMA, Angel. A cidade das letras. São Paulo: Brasiliense, 1985, 157 p.

RODRIGUES, Antonio Edmilson Martins. "Em algum lugar do passado. Cultura e história na cidade do Rio de Janeiro". In AZEVEDO, André Nunes (org.). Anais do Seminário Rio de Janeiro: Capital e Capitalidade. Rio de Janeiro: Departamento Cultural / NAPE / DEPEXT / SR-3 / UERJ, 2002, pp. 11-43.

_- "América renascentista - um ensaio: as experiências modernas no espaço da Baía da Guanabara - a dupla fundação da cidade do Rio de Janeiro: entre ideais e utopias". Morus, Campinas, 2006, v. 3, pp. 213-42.

SCHWARCZ, Lilia Moritz. A longa viagem da biblioteca dos reis. São Paulo: Companhia das Letras, 2002, $608 \mathrm{p}$.

SEVCENKO, Nicolau. Literatura como missão: tensões sociais e criação cultural na Primeira República. São Paulo: Companhia das Letras, 2003, 420 p.

URRY, John. O olhar do turista: lazer e viagens nas sociedades contemporâneas. São Paulo: Studio Nobel / SESC, 2001, 231 p. 


\section{Parte 2}

\section{Turismo e desenvolvimento territorial na Itália}




\section{Problematiche territoriali del turismo a Roma: due casi di studio}

Marina Faccioli

Premessa. - E' noto come il turismo vada inteso, oggi, soprattutto come un processo di produzione di valore che funziona mettendo a frutto la trasversalità fra più filiere, in via di continuo, necessario, "riaggiustamento". Il rinnovamento dei contenuti, in realtà, si ascrive a categorie concettuali e operative, perché se, da un lato, si tratta di una reimpostazione della definizione e composizione delle risorse che generano l'offerta, dall'altro, è l'intero approccio sociale, civile e culturale all'attività turistica che va cambiando profondamente, per la necessità di una prassi dell'apprendimento e della formazione che costituisca una soglia di accesso al settore. Una prassi, questa, di carattere fortemente selettivo, che si richiede non più solo agli operatori ma, sempre più, anche ai fruitori.

Si deve "saper" accedere a tanta parte dell'odierna offerta turistica, sia essa di carattere culturale, sportivo, ambientale, di intrattenimento. La competizione del mercato diventa competizione comportamentale, parte di un processo così fortemente congiunto, fra cambiamento continuo dell'offerta ed evoluzione della domanda, da creare condizioni in cui produttore e consumatore diventano 
facce della stessa medaglia e, insieme, generano e ridefiniscono il prodotto, anzi, "sono" essi stessi il prodotto turistico.

Ma c'è anche un cambiamento di punto di vista di carattere concettuale che guarda al turismo come fatto non straordinario, come fattore di rilettura analitica del processo territoriale e, insieme, come percorso specialistico di fruizione del territorio stesso. La rilettura di paesaggi e ambienti da vivere come contesti del quotidiano comporta anche la ridefinizione dei brand vincenti. I beni culturali minori, gli spazi da vivere e assaporare "lentamente", le scoperte delle storie locali, la cultura del far conoscere e dell'offrire cibo sono gli agenti di comunicazione oggi più forti nella nostra pratica di trasmissione di informazioni relative al turismo.

Sono molte le culture territoriali che il turismo propone. E c'è un turismo lento perché riguarda un territorio a sua volta "lento", fatto di un insieme di input complessi da decifrare e individuare perché nascosti nei percorsi che definiamo abitualmente come crescita urbana, percorsi che, piuttosto che crescita, trasmettono il senso del cambiamento di vere filiere programmatiche in cui il territorio compare "lentamente" dietro ai processi di urbanizzazione. E si esprime nelle culture fatte proprie dai city users e nelle pratiche dei residenti, sempre più competitors, questi, nei confronti dei visitatori e sempre più visitatori essi stessi, turisti dei propri luoghi, che essi medesimi collaborano a ricostruire, anche per negatività, a misura della propria domanda.

In accordo con una lettura dei processi territoriali di impostazione sistemica, noi guardiamo, in questa sede, a componenti dell'offerta turistica che si identificano con le componenti radicate, e, per certi percorsi, con le pratiche del "vissuto" che trovano spazio nei medesimi luoghi. In questi termini, l'analisi dei processi di fruizione turistica va a coincidere con lo studio dei milieux locali, fatti di soggetti individuali e collettivi, di patrimonio, percorsi, catene di riproduzione di valore aggiunto costruito nei territori (Dematteis, 2001). E i percorsi del turismo saranno distinti da 
pratiche di consumo di ecosistemi in cui, tuttavia, la fisionomia dei territori stessi come soggetti turistici risulterà in accordo con quei contenuti specifici che li differenziano e li qualificano consentendo ad essi di mantenersi in vita e autoriprodursi continuamente; $\mathrm{o}$, all'opposto, il turismo andrà per strade segnate da vicende di cedimento all'omologazione e al degrado, fino a far scomparire i luoghi medesimi come individualità distinte.

Dunque, le eventuali fasi di crisi del ciclo di vita del prodotto turistico e/o i periodi di maturità o obsolescenza di questo appaiono, alla luce dell'approccio territorialista, riconducibili alla perdita di vitalità del milieu come tramite fra soggetto e luogo, condizione che frequentemente può verificarsi con la rilocalizzazione di aziende o cicli produttivi, con il venir meno di condizioni di coesione sociale, con il progredire del degrado ambientale e delle condizioni di sussistenza di luoghi e spazi di interrelazione fra questi.

E' nell'ambito del processo sistemico che viene a comporsi anche un "agire insieme" fra produttori e consumatori di turismo, in fasi della produzione in cui siano ribaltati i rapporti tra offerta e domanda e in cui sia la collaborazione competitiva, piuttosto che la localizzazione o la gerarchia, a decidere. Nel sistema, per il mantenimento in essere di questo, il territorio diviene, di necessità, un patrimonio da ricostituire continuamente secondo un agire collettivo e mediante vicende complesse di riproduzione di specifico valore.

Fare turismolfare città. - In questa sede si vuole prendere in considerazione la valenza turistica come agente operativo rivolto alla creazione di percorsi di riorganizzazione territoriale, in particolare come fattore capace di ridefinire le condizioni di fruizione di certi contesti e, in quanto tale, parametro di interpretazione geografica. 
Qui ci interessa, in via specifica, studiare il processo turistico come percorso dell'urbanizzazione e parametro di lettura della complessità del processo metropolitano $\mathrm{e}$, in quanto tale, agente di integrazione fra culture e di promozione di consumi innovativi e originale fattore di produzione di attrattività territoriale. Quel che la città fà per rendersi ospitale, attraente, vivibile e "divertente" è, nei fatti, un lungo e difficile cammino che comporta una continua ricostruzione della propria immagine, una ricerca di rinnovamento che può assumere tratti di eccellenza anche in termini di spettacolarità, una costante attività di reinvenzione che si situa come imprescindibile fattore di marketing (Faccioli, 2009).

Il turismo può offrire, in questa dimensione, uno spazio di eccezionale portata alla domanda di reinvenzione di un brand territoriale altamente competitivo. Segmenti, potenziali o in atto, di un percorso di sviluppo turistico e processi di riqualificazione funzionale e d'immagine delle città sono dinamiche che possono procedere affiancate, tanto che l'una motiva e dà sostanza all'altra. Il percorso della riqualificazione e del cambiamento di senso e di funzione dell'immagine urbana, a sua volta, è processo complesso, denso di implicazioni, insieme, rigidamente funzionali, territoriali, sociologiche e comportamentali. La città è campo d'azione in cui si contrappongono o, più spesso si integrano e si confondono, sostituendosi continuamente, il luogo e il non luogo, il territorio segnato dall'esperienza e il "non territorio" (Webber, 1964), definito da una consolidata bibliografia come entità priva di spessore identitario e segnata dall'omologazione ${ }^{1}$.

Negli spazi delle nostre città gli stessi processi di riuso del suolo destinati a localizzazioni di funzioni specialistiche impostano frequentemente relazioni socio-territoriali difficili da spiegare secondo i tradizionali parametri di interpretazione

1 Il concetto di "non luogo" ha acquisito notorietà in Italia soprattutto grazie all'interpretazione di Marc Augé (1992). 
localizzativa. Si creano, infatti, aree di elevata qualificazione funzionale, spesso in settori urbani marginali, magari di nuova affermazione e di crescente notorietà, o zone di forte richiamo turistico, indifferentemente collocate nel tessuto edificato, che funzionano come tipologie urbane dotate di una immagine distintiva o, diversamente, prive di caratteri e spessori specifici, in accordo con pesanti processi di omologazione. La stessa caratterizzazione turistica di questi luoghi va, conseguentemente, a definirsi solo come uno fra i tanti input "diversamente" attrattivi che interessano queste parti di città, a cui fanno riscontro idonee riletture e nuove categorie interpretative dell'analisi geografica.

E' noto come in linea con l'affermarsi di dinamiche rilocalizzative coerenti con i caratteri specifici della recente stagione del processo urbano si siano andate confermando diverse riformulazioni del paradigma centro/periferia.

La nodalità dei territori appare sempre più spesso definita da relazioni a più scale nell'ambito delle quali la centralità dei luoghi assurge a livelli globali anche connettendosi a decisioni strategiche esterne ai luoghi stessi. D’altro lato, le marginalità territoriali effettive sembrano oggi le zone d'ombra "saltate" da percorsi di sviluppo di non facile classificazione, che funzionano perché inseriti in filiere di reticolarità metropolitane, o nelle maglie larghe di certi "periurbani", o in siti morfologicamente o climaticamente inospitali eppure riconvertiti come "luoghi" dal turismo (Faccioli, Salvatori, 1997).

Ma lo stesso processo turistico va riconvertendo i parametri su cui selezionare i diversi gradi di attrattività da richiedere al territorio. Il non-place urban realm (Webber, 1964), definizione canonica del non luogo urbano, coglieva qualcosa di marginale perchéirrimediabilmente estraneo alla centralità, fisica e funzionale della città moderna. Ma è proprio in tanti non-places delle nostre città che si annida, anche sulla base della pianificazione urbanistica istituzionale, la rinascita di pezzi di città rimodellati, ricostituiti e 
rimessi in circuiti relazionali, attrattivi, condivisibili e come tali “sostenibili". Si tratta spesso di sedi di funzioni innovative di rango superiore, che sfruttano vocazioni all'internazionalità di certi luoghi apparentemente isolati rispetto allo sviluppo. O di pezzi di città in cui si ricostituisce il movimento, lo scambio culturale, il rimodellamento dell'immagine, la messa in circolo di linguaggi di nuova sperimentazione nel commercio, nella formazione, nell'intrattenimento. O di "superluoghi", che verificano uno sganciamento dal programma territoriale convenzionale e, insieme, una nuova legittimazione nel "fare presa" (Bolocan, Goldstein, 2007) e nel creare spazialità sociale, proprio partendo da certe negazioni di socialità, se non nei termini di nuove accezioni di spazio "pubblico", come rivisto e condiviso da altre culture, che siano, queste ultime, prodotte dall'associazionismo o soltanto dal singolo cittadino (Loda, Hinz, 2011; Mancini, 2010).

Roma, un progetto per "nuovi turismi”. - Roma presenta una connotazione della propria offerta turistica ancora percepita come monocentrica e fortemente polarizzata, in contrasto con un policentrismo "reale" della socialità, delle aggregazioni insediative, dell'associazionismo locale e della domanda culturale e civile che si è andato radicando nella città, in forme non sempre coincidenti con gli ordinamenti municipali. La complessa storia delle relazioni fra la capitale e il proprio contesto ha generato dispersione degli interventi ed effetti di crescita urbana apparentemente precari e casuali, in realtà dettati da precise regìe pianificatorie, in termini di disegni incompiuti, abusivismo, crescita urbana per parti "separate", interventi in deroga ai piani urbanistici; situazioni che hanno fortemente condizionato ogni programma di valorizzazione coerente dell'immenso patrimonio territoriale (Marcelloni, 2003).

Come nel caso di altre aree metropolitane, le vicende istituzionali della riqualificazione del territorio romano nella recente 
pianificazione urbanistica sono andate necessariamente a coincidere, anche in vista della messa in opera di percorsi di valorizzazione turistica, con la ricucitura di frange periferiche e il riallaccio di queste al tessuto edificato, con l'obiettivo dell'invenzione di occasioni inedite di centralità e della creazione di spettacolarità, anche là dove l'immagine della complessità urbana sembra disperdersi.

Dalla marginalità di tanti settori dell'area romana, all'acquisizione di una consapevolezza della ricchezza e della vastità del patrimonio territoriale, paesaggistico, storico-artistico, ambientale, la storia della gestione dell'offerta turistica romana presenta vicende controverse cui, sempre più, partecipano assetti, input, scenari estremamente diversificati, itinerari "minori" eppure vitali e specialistici, nicchie che funzionano come work in progress apportando continue scoperte di occasioni di mobilità e scambio e, spesso, inventando nuovi linguaggi di comunicazione che diventano attrattori forti di flusso turistico. E' il "territorio" che prevale sulla politica, ma occorre lavorare perché tutto non resti al livello di domanda disattesa o di occasione incompiuta.

E' la storia del patrimonio "minore", dei segmenti potenziali di sviluppo del turismo che connota, in realtà, tanta parte delle componenti più "rinnovate"e intriganti su cui si è costruito il brand turistico romano.

Qui guardiamo, in un caso di studio, alla campagna, alle ville, ai palazzi e alle imprese dei Castelli Romani; e, in un altro caso, alle spiagge, al tracciato terminale della Valle del Tevere, ai canali, alle marane e alle immense aree verdi che ornano il litorale di fronte a Roma, nei complessi meandri dell'urbanistica del grande territorio di Ostia.

In entrambi i contesti la radice delle problematiche territoriali relative alle località prese in considerazione è riconducibile a complesse situazioni relazionali che le stesse località vivono nel contesto metropolitano romano. 
Da un lato, il caso di studio dei Castelli come destinazione turistica fà riferimento alle dinamiche attraverso le quali questo settore si è confrontato con l'area romana attraverso il lungo percorso di consolidamento di legami viari, commerciali e residenziali, già radicati in alcune importanti fasi della storia ambientale locale del passato.

D'altro lato, il settore sud-occidentale, attraversato dal Tevere, strutturato sugli assi dell'Ostiense/Via del Mare, della Via Cristoforo Colombo e dell'autostrada per l'aeroporto di Fiumicino, costituisce un problematico affaccio al mare per l'area romana, caratterizzato da morfologie urbane diversificate, organizzate sul recupero di aree degradate, o sul cambiamento d'uso dei suoli condizionato dal prevalere di diversi intenti progettuali e, insieme, sulla presenza vincolante nei confronti di una espansione indiscriminata, in più casi esercitata dalla presenza di aree verdi di grande estensione e di elevato pregio ambientale.

Nel caso dei Castelli Romani come in quello di Ostia la programmazione territoriale volta al recupero e alla riqualificazione di patrimoni culturali, paesaggistici, ambientali, economicoproduttivi si è frequentemente integrata con scelte relative all'impianto di processi di produzione di valore aggiunto per il rinnovamento dell'offerta di servizi commerciali e infrastrutture o per la creazione di aree di rispetto per la progettazione di strutture rare o innovative, sebbene il più delle volte non adeguatamente contestualizzate, soprattutto nel quadro della ricerca di brand turistici originali.

I Castelli Romani. - Questarea, dalle dimensioni di una città media, dotata di attrattori turistici di alto livello, è al centro di operazioni di riqualificazione, e in qualche caso di riuso, di patrimoni storico-artistici di evidente rilievo (dalla romana Tuscolo all'Abbazia di rito greco di Grottaferrata, al complesso delle Ville rinascimentali di Frascati). 
Larea costituisce la prima, la più antica e quella di maggiori dimensioni, fra le zone di espansione residenziale dell'area urbana romana, risultante dall'integrazione fra tessuti produttivi, sociali e territoriali, interessata da processi selettivi di suburbanizzazione e periurbanizzazione, solo parzialmente legittimati da interventi integrati di pianificazione, a loro volta diretti a giustificare la presenza di operazioni di decentramento/delocalizzazione di diverse realtà settoriali e comparti funzionali.

Questo settore rappresenta dal punto di vista funzionale quel che resta di uno dei punti "forti" dell'area metropolitana romana, già compreso fra gli anni Settanta e Ottanta in un disegno di decentramento funzionale che avrebbe dovuto correre lungo un asse tangente a Est del Centro storico. Disegno, peraltro, mai realizzato e più volte riproposto secondo diverse espressioni e intenzioni progettuali e ripreso, fin nell'ultimo Piano regolatore della Capitale, nel progetto di un Sistema Direzionale Orientale. Forti input tendenti alla messa in atto di un percorso di decentramento delle funzioni centrali sono, tuttavia, già rappresentati, in questo settore del territorio, dall'Università di Roma "Tor Vergata", inserita nel disegno di un grande parco scientifico-tecnologico; dal secondo Policlinico di Roma; da laboratori scientifici che fruiscono di una localizzazione favorevole al collegamento con insediamenti direzionali e di livello avanzato (Centro Servizi della Banca d'Italia, sede del Consiglio Nazionale delle Ricerche, laboratori di fisica nucleare dell'Euratom-ENEA, a Frascati); da quel che resta del diversificato, storico complesso delle grandi imprese multinazionali della fascia settentrionale pontina; e infine da aree di recupero urbanistico che interessano problematiche residenziali e vecchi settori infrastrutturali, come nel caso dell'aeroporto di Ciampino.

La composizione dell'offerta turistica locale si fonda sull'intersezione fra risorse tipiche di un complicato mix urbano/ metropolitano, patrimoni paesaggistici e beni culturali. Le dinamiche originali della mobilità locale si presentano in forme di 
escursionismo proveniente da Roma o da località adiacenti e di un intenso pendolarismo interregionale.

L'area dimostra di aver acquisito la lezione, oggi sempre più condivisa, che propone come attrattori turistici i patrimoni della storia industriale, manifatturiera, artigianale dei luoghi come fattori privilegiati di integrazione con l'offerta territoriale connessa al turismo, all'uso del tempo libero, alla scoperta di nuove relazionarietà, interpersonali e nel rapporto con natura e ambiente.

Il turismo "d'impresa" è, infatti, quel segmento strettamente interrelato con il rinnovato scambio fra tempi e spazi del lavoro e del leisure, in cui i business visitors praticano paesaggi, spiagge, sport tipici, shopping e cultura, cogliendo intrecci fra relazioni urbano/ metropolitane complesse. Si tratta di percepire quel tratto originale che l'effetto "città", dove c'è, conferisce a ogni input del processo turistico.

Nel nostro settore l'offerta turistica locale si diversifica secondo tipologie complesse che integrano con le risorse paesaggisticostoriche processi di frequentazione più intensi e di diverso segno rispetto al passato, derivanti da una progressiva selezione di funzioni di servizio qualificate, che attraggono pendolarismo per lavoro e studio o turismo congressuale. E' interessante, in questo senso, il riuso di strutture monumentali, fra cui alcune Ville di impianto cinque-seicentesco situate nell'area tuscolana, nelle quali hanno trovato spazi e strutture adeguate, insediamenti diversi quali una sede congressuale di proprietà dell'Università di Roma “Tor Vergata", a Villa Mondragone, nel territorio di Monteporzio, e una struttura alberghiera spesso utilizzata nel campo della formazione professionale in attività di servizio di alto livello, a Villa Rufini, alle porte di Frascati.

Sono questi i lasciti della stratificazione di un forte spessore ambientale, a cui hanno concorso, dall'età antica in avanti, vasti processi di integrazione territoriale, lasciti tanto incisivi ed efficaci da trasformare in attrattori e segmenti potenziali di sviluppo 
turistico i patrimoni e gli itinerari della storia. E' il ruolo "attivo" di queste strutture che ha consentito nel tempo l'integrazione fra paesaggi, funzioni e strutture. Soggetti privilegiati fra questi sono le Abbazie, che hanno funzionato quali agenti di un potere reale, urbanistico-territoriale, economico-finanziario e strategico che si è moltiplicato entrando a far parte di alleanze fra proprietà laiche e pontificie, fino ad acquistare diritti nella gestione dell'allestimento di piani urbanistici e infrastrutture, collegamenti viari, contestualità culturali e relazioni di mercato.

A ben vedere, questo gioco di interconnessioni configura una circolarità tale per cui la persistenza e il consolidamento dello spessore territoriale che si è costruito, nell'arco di una lunga storia, in tanta parte del ricco e articolato microcosmo dei Castelli Romani, è rimasto forte ancora oggi, ha "fatto città", ha creato condizioni di vita competitive, selettive, ha integrato profondamente questi territori nei ritmi e nelle regole della metropoli.

I "subsistemi" territoriali che sono stati prodotti già da alcuni secoli da parte di queste dinamiche hanno conquistato condizioni di progressiva stabilità e si sono consolidati nel tempo essenzialmente in virtù della presenza in loco di funzioni altamente competitive, perché rare. Nell'Abbazia di Grottaferrata hanno trovato spazio una Scuola di miniatura e paleografia greca, la Scuola tipografica orientale, un laboratorio di restauro di codici e libri rari, un Museo archeologico e un Archivio. Queste diverse, complesse attività fortemente specializzate hanno generato, nel loro reciproco interagire, processi stabili di creazione di attrattività territoriale che sono andate progressivamente qualificando il territorio nel segno di una accresciuta cultura dell'accoglienza e dell'ospitalità, anche secondo moderni parametri di ordine turistico.

Lo stesso complesso abbaziale, insediato in un settore fortemente significativo dell'area romana, si è posto fin dall'età altomedievale come un agente territoriale decisivo che, mediante una forte capacità relazionale, la produzione di importanti cicli di 
esternalità e la continua creazione di specifico, crescente "valore di scambio", ha controllato strategicamente un territorio esteso fra Tivoli, Frascati, Albano, Velletri e il mare ed è entrato in contatto con il vasto bacino culturale che, attraverso alcune regioni dell'Italia meridionale, si affacciava sul Mar Mediterraneo. Nel complesso dell'Abbazia funzionavano fra il Medioevo e l'età moderna e contemporanea, attività agricole (coltura della vite e produzione di vini), manifatturiere (lavorazioni alimentari e fabbricazione della carta), infrastrutturali (la prima ferrovia pontificia), la costruzione di castelli e fortificazioni, fino a impianti idraulici innovativi che fornivano energia alle fabbriche e alimentavano "giochi d'acqua" nelle ville rinascimentali dei nobili proprietari terrieri.

Oggi la progettualità relativa a una fruibilità culturale e ambientale dei medesimi complessi in funzione di un target turistico passa necessariamente, da un lato, per la via di una conoscenza e interpretazione di risorse e vocazioni millenarie che, a loro volta, hanno consentito, dove è stato possibile, il mantenimento di antichi equilibri ecosistemici; e, d'altro lato, si colloca necessariamente nel quadro di una contestualizzazione dei luoghi entro il sistema ed entro la massa critica degli attrattori messi in funzione nell'intera, attuale, area metropolitana della capitale.

Il mare di Roma e il territorio di Ostia. - Ostia, il quartiere romano che si estende sul litorale tirrenico, si presenta come soggetto “eccellente" dal punto di vista della dotazione di potenzialità idonee a uno sviluppo turistico.

Le risorse locali si articolano sulla presenza di vaste spiagge, di un ben conservato sito archeologico di età romana, Ostia Antica, fra i primi al mondo per importanza, e su un contesto ambientale naturale interessante, costituito dal corso terminale del fiume Tevere, da grandi pinete, da distese di dune litoranee, da aree verdi di grande estensione, fra cui la Tenuta di Castelporziano, riserva 
presidenziale, che comprende una azienda agricola che, a sua volta, opera in un territorio di 6000 ettari.

La gestione attuale del territorio in funzione della definizione dello stesso come destinazione turistica procede attraverso tre tipologie di progetti di "riprogrammazione" territoriale messi in atto, in maniera trasversale, da parte di soggetti locali pubblici e privati.

C'è una progettazione di carattere istituzionale basata sulla creazione di un "Secondo Polo Turistico Romano", che comprende l'area che si apre a ventaglio fra il centro storico e l'intero litorale della Provincia di Roma, destinato a integrare l'offerta del Primo Polo Turistico, costituito dal Centro storico monumentale. Questo Secondo Polo è inserito nel "Progetto Newper" (New Performances for Mediterranean Tourism), grande programma internazionale che prevede una revisione del sistema della governance delle politiche turistiche volta a promuovere una diversa attenzione al territorio e alla definizione di segmenti potenziali di sviluppo del turismo, a loro volta centrati su itinerari "minori", finora considerati "di seconda linea".

I soggetti che operano nell'ambito del marketing locale, a loro volta, sono impegnati in attività di diversa matrice, imprenditoriale e commerciale, per la messa in atto di itinerari alternativi e proposte integrate, volti a incrementare i flussi e la durata del soggiorno a Ostia dei turisti che, a vario titolo, visitano Roma, e dei viaggiatori in sosta o in transito nell'adiacente aeroporto di Fiumicino. Le proposte riguardano itinerari organizzati su percorsi di natura ecoturistica e naturalistica; la presentazione di eventi, spesso spettacolari, legati al mare; la ristorazione; attività sportive, in particolare della nautica nel nuovo Porto turistico; attività di intrattenimento; visite culturali al sito archeologico di Ostia Antica.

I residenti e certi gruppi di visitatori gestiscono altre dimensioni progettuali, di evidente valenza sociale, essenzialmente costruite sul consenso partecipativo locale, rivolte alla promozione 
di condizioni di miglioramento della qualità di vita dei residenti come input primario per la realizzazione in loco di una destinazione turistica efficiente. Questo progetto si fonda su un insieme di proposte avanzate da iniziative del locale Municipio e da numerosi soggetti dell'associazionismo locale ed è volto a evidenziare e soddisfare la richiesta di messa in rete dei servizi di largo consumo, in particolare attraverso una interscalarità dei collegamenti infrastrutturali, a facilitare la mobilità interna e a riorganizzare e incrementare l'occupazione locale, soprattutto dei giovani, mediante una revisione e reinterpretazione delle effettive potenzialità offerte da risorse e patrimoni del territorio. Questa ultima tipologia di programma prevede attività didattiche volte a far conoscere ai residenti e ai visitatori altri aspetti dell'offerta territoriale, in particolare per quanto concerne l'accessibilità a beni culturali ancora non conosciuti perché non esplorati, né interessati da adeguati percorsi di comunicazione.

Lo scenario che oggi Ostia propone ai visitatori è caratterizzato da notevoli e interessanti contraddizioni.

Anzitutto, un problema infrastrutturale che è l'anima del difficile rapporto con Roma, per il notevole flusso del pendolarismo in atto. Una fisionomia urbana problematica, caratterizzata da una struttura urbanistica complessa e disordinata, con grandi settori di residenze "periferiche", architetture destinate alla balneazione che hanno invaso le spiagge, esempi di architettura razionalista del primo Novecento ed edifici legati alla storia istituzionale del territorio. E un insieme interessante e originale di attrattori "alternativi", tipici di un territorio da fruire in tempi e spazi quotidiani, "lenti" (Lanzani, 2011), come tanti fra i paesaggi solcati dal Tevere e dai canali della bonifica idraulica, spiagge orlate di dune, oasi florofaunistiche con caratteristiche rare, tramonti sul mare, passeggiate al porto turistico.

Ostia trae la propria originale singolarità dall'essere un prodotto turistico leggibile da più punti di vista: è una città nella città di Roma, un incastro di situazioni insediative, culturali, 
attrattive che costituiscono, se organizzate e comunicate, un input nuovo su cui puntare per "fare" turismo. E' un territorio che porta i segni della storia della bonifica dell'Agro romano, di numerosi progetti urbanistici, è meta dell'escursionismo dei romani e una destinazione turistica in evidente fase di trasformazione. E, per tutti questi motivi, è una delle situazioni che, all'interno della città di Roma, danno la misura di un policentrismo reale, fatto di situazioni interculturali, di spinta al rinnovamento, di altra domanda, di offerta di attitudini professionali originali, di richiesta di nuove relazionarietà soprattutto da parte della numerosa popolazione giovane.

E' interessante rilevare come a Ostia, in realtà, proprio il territorio, che è un work in progress in continua trasformazione, costituisca l'infrastruttura più presente e quella che propone più articolate prospettive.

Perché non è l'infrastruttura costruita, formata da strade e ferrovie, quella che più dà forma e senso al progetto territoriale che può qualificare definitivamente Ostia come luogo turistico. L'infrastruttura di base è, piuttosto, quella naturale, fatta dalla rete idrografica, dalla linea di costa e dall'area verde. Elementi, tutti questi, che hanno funzionato da veri vincoli urbanistici, componenti performative della crescita urbana di Ostia, quasi agenti di rispetto e di salvaguardia dell'intera linea del litorale.

La rete idrografica, i canali e i corsi d'acqua naturali sono un tessuto che struttura ovunque il territorio e attraggono forme di diportismo minore, piccole attività di pesca, pratiche sportive, formano scorci di paesaggio che richiedono manutenzione e continua ristrutturazione.

L'area verde non è solo un parco urbano potenziale, perché è arricchita da emergenze archeologiche e storico-artistiche non ancora conosciute né esplorate mediante modalità istituzionali: la Via Severiana e la Villa di Plinio sul litorale, il Centro Giano e Ficana nell'entroterra, nella campagna che risale verso Roma. Queste aree 
rappresentano alcune fra le prospettive più originali per il futuro turistico del litorale romano, perché promettono formazione e occupazione per i giovani, magari gli studenti residenti, in grado di organizzare itinerari specialistici come "percorsi di apprendimento", per far conoscere la storia di quei luoghi e offrire esperienze nuove di fruizione della campagna e delle locali vocazioni all'ospitalità.

Dunque, sull'infrastrutturazione naturale, fatta di mare, fiume, verde urbano, campagna si fondano anche per Ostia gli input più creativi. E sul paesaggio deve puntare il litorale romano per essere pienamente competitivo e funzionare come attrattore effettivo. Ma su un paesaggio che, tuttavia, rappresenti, al tempo stesso, un pezzo di città, un angolo di metropoli, uno spettacolo intrigante della attuale dimensione di vita urbana.

E si deve guardare a un altro modo di pensare e promuovere l'idea di infrastruttura, intendendola piuttosto che come struttura di servizio, come tramite progettato per produrre urbanizzazione e "valore" territoriale, dunque come strumento materiale in grado di lavorare per tenere in vita e rendere fruibili le componenti vitali dei luoghi. E su questo sarà opportuno costruire per il litorale romano un brand per la promozione di qualità della vita, ospitalità, cultura e benessere,

Il litorale va ripensato, mettendo in rete tante intenzioni diverse, come progetto urbano-metropolitano che non nasconda le differenze e, tuttavia, sia capace di ricucire continuamente quei margini che non funzionano nello scambio fra più piani di infrastrutturazione e fra le tante "città nella città" che Ostia rappresenta, parti di città che hanno storie territoriali diverse da raccontare e che procedono per strade e a velocità differenti. Allora si potrà fare turismo, se Ostia diventerà parte di Roma, e della metropoli accoglierà e farà proprie tutte le opportunità e le contraddizioni.

E il primo segmento del turismo saranno, credibilmente, proprio i residenti, cioè i giovani che negli ultimi anni andavano 
ad abitare a Ostia in cerca di vantaggi economici e, oggi, danno invece il segno del cambiamento perché in più settori portano aree di professioni e professionalità nuove e diverse. E gli anziani, per lo più romani in trasferta dall'interno della città in direzione del mare, che vanno a vivere a Ostia per respirare, camminare e correre lungo il mare tutti i giorni. Gli anziani, che sono ormai una nicchia formidabile per la domanda di turismo del futuro nei Paesi industrializzati. E per questi residenti si dovranno creare le migliori condizioni di qualità di vita, organizzare effettive occasioni di migliore ospitalità e accoglienza. Perché le recenti analisi volte ad indagare gli aspetti e le opportunità esperienziali presentati dai percorsi dei tanti odierni "turismi" confermano come dagli abitanti si debba necessariamente partire per imparare a offrire ospitalità, per "saper" accogliere i turisti e ogni visitatore ( Istituto Nazionale Ricerche Turistiche, 2012).

Perché il mare di Roma può certamente rappresentare una straordinaria scoperta. Ma il mare da solo non basta, ci vuole un mare metropolitano, che sia l'offerta del benessere, dello svago e del divertimento di una città intera. Perché le praias di Rio de Janeiro sono uniche perché è unica "quella" città, e il mare di Rio è insieme molte cose, business, musica, sabbia e incredibile traffico metropolitano. Il mare, infatti, in nessun Paese del mondo è capace di garantire, da solo, la messa in funzione e il successo di una "destinazione" turistica. Le spiagge e le onde devono essere immagini "forti" da vivere, in cui contestualizzare esperienze e "atmosfere", perché sfondi eccezionali di luoghi eccezionali. Possono creare dimensioni speciali per ambientazioni speciali, ma servono vere "città" perché prendano forma spettacoli attualizzanti e coinvolgenti, da ricordare e raccontare nella loro straordinarietà.

I Castelli Romani proporranno molto di più se finalmente diventeranno soggetto di punta di una politica programmatica impegnata nello sviluppo delle filiere dell'attrattività territoriale romana. Se le ville di età romana si apriranno a offrire frequentazioni 
suggestive. Se i paesaggi riproporranno agricoltura "vera" e non virtuale, e dunque anche una vera cultura dell'alimentazione. Se l'enogastronomia ridiverrà finalmente un'offerta originale che ha appreso la cultura del cambiamento. Se la qualità di vita consentita dai luoghi si radicherà come fattore di benessere e "divertimento" metropolitano. Soprattutto, se le analisi e le ricerche di progetto si trasformeranno in idee e, dunque, in programma politico.

Ostia rimarrà, prevedibilmente, un soggetto critico dell'urbanistica romana, un progetto in fieri, un lascito della crescita urbana problematica del dopoguerra e, ancor prima, della politica di piano che riguardava i primi quartieri strategicamente "espulsi" da Roma e i grandi eventi celebrativi dello sviluppo della romanità alla conquista del mare.

Potrà, tuttavia, proporre anche molto di più, perché il turismo non è solo vacanze al mare né edilizia celebrativa, ma ricerca, necessaria e contestuale, di conoscenza di complessità ed esperienze, di movimento, di percorsi che mettano insieme più segmenti di offerta per l'accesso a opportunità di cambiamento, entro filiere più grandi di informazione e formazione.

Resta la città il soggetto "forte" a cui si chiede di proporre sé stessa come significante, piuttosto che come distratta sommatoria di parti separate e incoerenti, a cui si sovrapponga un turismo "dovuto" per motivazioni già radicate o per vantaggi di posizione.

"Fare" città è d'obbligo per la Capitale, secondo un progetto finalmente "informato" sulla propria storia reale, che ripercorra le tappe della promozione di un'idea costruita, in progressione, su una domanda di riedizione della vecchia città compatta, sulla ridefinizione di input ereditati, sulla riproposizione dialettica dell'immensa periferia della precarietà urbanistica, già destinata nell'ultimo piano regolatore al ripensamento e alla ristrutturazione. Solo intendendo in maniera responsabile e consapevole gli input che provengono dalla società reale e individuando le posizioni rispettive di residenti e visitatori nella continua rimessa in discussione di punti 
di vista non più esclusivamente "centrali" né "periferici", Roma avrà l'opportunità di farsi conoscere come destinazione in linea con i processi reali e "sensibili" della attuale trasformazione urbana.

Dai cittadini emerge la richiesta di una Roma turistica "diversa" rispetto alle riproduzioni da cartolina che persistono nell'immaginario generale e nella comunicazione di maniera delle vocazioni attrattive del turismo romano. Dalla risposta responsabile a queste domande dipenderanno i tratti, i colori, gli scenari di un'altra Roma turistica, da ricercare, per qualche tratto, già nel nostro presente e in gran parte da costruire per il futuro.

\section{Bibliografia}

M. Augé, Le sens des autres. Actualité de l'anthropologie, Parigi, Fayard, 1994.

M. Augé, Non-lieux. Introduction à une anthropologie de la surmodernité, Parigi, Seuil, 1992.

M. Bolocan Goldstein, Territorialità attive e proiezione dell'ordine funzionale, in La civiltà dei superluoghi. Notizie dalla metropoli quotidiana, Bologna, Damiani, 2007, p. 181.

M. Carta, L'armatura culturale del territorio, Milano, Angeli, 1999.

A. Clementi, G. Dematteis, P.C. Palermo (a cura di), Le forme del territorio italiano, Vol. I, Temi e Immagini del mutamento; Vol. II, Ambienti insediativi e contesti locali, Roma-Bari, Laterza, 1996.

S. Conti, C. Salone, Per una grammatica della programmazione territoriale, in M. Faccioli (a cura di), Quali filiere per un progetto metropolitano?, Milano, Angeli, (in corso di pubblicazione).

M. Cremaschi, Atlante e scenari del Lazio metropolitano, Firenze, Alinea, 2010.

G. Dematteis, Possibilità e limiti dello sviluppo locale, "Sviluppo locale", 2004, 1, pp. 10-30.

G. Dematteis, Per una geografia della territorialità attiva e dei valori territoriali, in P. Bonora (a cura di), SLoT Quaderno 1, Bologna, Baskerville, 2001, pp. 11-30.

Ente Bilaterale Turismo Lazio, Roma e Lazio, il turismo in cifre, 2008-2011, Roma, 2012.

C. Emanuel, La sostenibilità urbana: convergenze tematiche, definizioni e approcci analitico-valutativi, in C. Emanuel, P. Vallaro (a cura di), Prove di sostenibilità. 
Progetti, piani e valutazioni per un processo di sviluppo urbano sostenibile a Novara, Novara, Università del Piemonte Orientale "Amedeo Avogadro" Comune di Novara, 2005, pp. 7-22.

M. Faccioli, Filiere urbane o nuovi percorsi distrettuali? Cenni per una proposta di metodo, "documenti geografici", 2011, 16, pp. 5-21.

M. Faccioli (a cura di), Processi territoriali e nuove filiere urbane, Milano, Angeli, 2009.

M. Faccioli, L'espansione di Roma Capitale in un settore della sua Campagna: gerarchie funzionali e insediative nel corso del Novecento, in F. Salvatori, E. Di Renzo (a cura di), Roma e la sua Campagna. Itinerari del XX secolo, Roma, Società Geografica Italiana, 2007, pp. 394-409.

M. Faccioli, E. Puppio, Nuovi turismi. Il valore del territorio di Ostia, in Roma Capitale (a cura di), Roma cresce. Brasile, Cina e Russia: mercati strategici di un nuovo turismo per l'Italia e la Capitale, Milano, Angeli, 2013, pp. 220-246.

M. Franch, Destination Management, Governare il turismo tra locale e globale, Torino, Giappichelli, 2002.

F. Governa, La dimensione territoriale dello sviluppo socio-economico locale: dalle economie esterne distrettuali alle componenti del milieu, in A. Magnaghi (a cura di), Rappresentare i luoghi. Metodi e tecniche, Firenze, Alinea, 2001, pp. 309-324.

F. Governa, S. Saccomani, Periferie urbane. Definizioni, interpretazioni, politiche, in F. Governa, F. Saccomani (a cura di), Periferie tra riqualificazione e sviluppo locale. Un confronto sulle metodologie e sulle pratiche in Italia e in Europa, Firenze, Alinea, 2002, pp. 13-34.

G. Imbesi, P.N. Imbesi, M.L. Pilloton, All'ombra della metropoli: per una lettura dei volti diversi di Roma, città del turismo, in M. Faccioli (a cura di), Quali filiere per un progetto metropolitano?, Milano, Angeli, (in corso di pubblicazione).

Istituto Nazionale Ricerche Turistiche (a cura di), Impresa Turismo, Roma, Unioncamere, 2012.

S. Landi, Paesi con l'anima, Milano, Terre di Mezzo, 2011.

S. Landi, La marca nel turismo, Milano, Touring Club Italiano, 2003.

A. Lanzani, In cammino nel paesaggio. Questioni di geografia e urbanistica, Roma, Carocci, 2011.

M. Loda, M. Hinz (a cura di), Lo spazio pubblico urbano. Teorie, progetti e pratiche in un confronto internazionale, Pisa, Pacini Editore, 2011.

A. Magnaghi, Il progetto locale, Torino, Bollati Boringhieri, 2000.

A. Magnaghi, Il territorio dell'abitare. Lo sviluppo locale come alternativa strategica, Milano, Angeli, 1991. 
N. Mancini, Percorsi di territorializzazione di spazi pubblici interstiziali a Firenze, tesi Dottorato "Cultura e territorio", Roma, Università di Roma "Tor Vergata", 2010.

M. Marcelloni, Pensare la città contemporanea. Il nuovo piano regolatore di Roma, Roma-Bari, Laterza, 2003.

C. Minca, Spazi effimeri. Geografia e turismo fra moderno e postmoderno, Padova, CEDAM, 1996.

Nuovi Indicatori di benessere - Monitorare la qualità dello sviluppo nella capitale metropolitana, in Capitale Metropolitana, il Progetto Strategico della Provincia di Roma, Roma, Provincia di Roma, 2012.

Piano Territoriale Provinciale Generale, Roma, Provincia di Roma, 2010.

E. Proietti, Capitale Metropolitana, Periferie Comuni. Rapporto di studio sulla condizione sociale, economica e territoriale, Roma, Provinciattiva SpA, Ufficio studi socioeconomici e Ufficio sistemi tecnologici, 2010.

L. Van Den Berg, L.S. Burns, L.H. Klaassen (eds), Spatial Cycles, Rotterdam, Gower, 1987.

J. Van Der Borg, Tourism and Urban Development, Rotterdam, Erasmus Universiteit, 1991.

M. Webber, The urban place and the non-place urban realm, in M. Webber (ed), Explorations into Urban Structure, Philadelphia, Pennsylvania State University Press, 1964, pp. 79-153. 


\section{Il Lago di Como: i molti turismi di un territorio turistico}

Paola Nicoletta Imbesi

Per una fenomenologia del settore turistico. - Il settore turistico rappresenta per molti territori italiani uno dei settori cardine nel quadro dello sviluppo economico: tali territori spesso caratterizzati dalla presenza di risorse storico ambientali notevoli e, nel contempo $\mathrm{da}$ forti pressioni alla trasformazione (insediative ma anche infrastrutturali e funzionali), trovano nel turismo uno scenario irrinunciabile di sviluppo da cui dipendono grandi aspettative anche se non sempre sono corrisposte ai risultati sperati. In un senso figurativo possiamo dire che il settore turistico costituisce un elemento strutturante, strumentale per la definizione dell'assetto del territorio sotto molti aspetti:

- offre un reale scenario di sviluppo economico e di rinnovamento culturale, funzionale e sociale;

- organizza e diversifica i flussi di arrivo/visita in funzione della configurazione spaziale o di un calendario di eventi;

- scandisce la permanenza e quindi la crescita/decrescita della popolazione "fluttuante"; 
- configura e usa una rete di poli a "geometria variabile" (nello spazio e nel tempo) funzionali alla fruizione del territorio.

D’altra parte il territorio nel suo complesso, con le sue risorse e le sue attrattive, costituisce da sempre il principale "capitale", elemento di attrazione sul quale costruire attività e attrezzature di servizio al visitatore. I beni e le risorse che determinano tale capacità d'attrazione non sono "esclusivamente" orientati al turista ma, al contrario, possono riferirsi ad una platea molto più vasta di utenti creando interconnessioni complesse e spesso conflittuali fra il territorio, i turisti e i molti fruitori che, a vario titolo, vivono, lavorano o amministrano il territorio stesso. Così, ad esempio, una chiesa trova le sue origini non certo per funzioni turistiche ma può rappresentare un fattore d'attrazione per un turismo culturale; un complesso sportivo o uno spazio pubblico urbano possono trovare usi urbani ordinari e straordinari. Inoltre, molto spesso, contribuiscono a determinare l'attrattività di un'area attrezzature e servizi propri della società civile: la presenza di un trasporto pubblico efficiente, di una bassa congestione insediativa e viabilistica, di una buona dotazione di funzioni e servizi collettivi o di aree verdi. Condizioni, queste, che travalicano lo specifico settore turistico per rivolgersi alla generalità della popolazione di in una determinata area.

Nello strano rapporto, spesso conflittuale, fra turismo e territorio il turismo si può definire come una forma d'uso "eccezionale" di un determinato territorio in un lasso di tempo controllato ("Turista è colui che si "sposta da un posto all'altro per motivi non legati al proprio lavoro, fermandosi per più di una notte e meno di un anno", Koolhaas, 1995), portando così alla definizione di inedite integrazioni fra modi d'uso diversificati nello spazio come nel tempo. Può rappresentare una concreta occasione di valorizzazione e di impulso economico come settore produttivo "ad hoc" in grado di conservare e le risorse endogene e di rendersi 
strumento per la promozione e la crescita territoriale. Il fenomeno turistico, oggi profondamente cambiato dai tempi dell'elitario "gran tour" novecentesco, spostandosi dal concetto di "viaggio" geograficamente determinato verso quello della percezione e la fruizione dei luoghi di qualunque viaggio o spostamento fuori dagli schemi della vita quotidiana (De Napoli, 2005). L"altrove", che il viaggiatore romantico considerava un luogo lontano, nella contemporaneità tende ad annullare l'importanza dello spostamento nello spazio per trasformarsi in un'esperienza di conoscenzal fruizione del territorio nel "tempo liberato dal lavoro". D'altra parte il turismo, in quanto forma di viaggio (o conoscenza) nel territorio, "è una forza centrale e non periferica nelle trasformazioni storiche" (Leed, 1991) che ha segnato la nascita del concetto di territorializzazione per creare la mappatura di uno spazio fisico determinato.

Negli ultimi decenni il modello di domanda turistica sta, pur con una certa lentezza, modificandosi e articolandosi. Diminuisce il turismo di gruppo (che mantiene però una quota importante soprattutto verso le mete tradizionali) a favore di quello individuale, generando nuovi tipi di domanda, articolati in quanto connessi sia alla qualità "generale" dei servizi offerti (servizi ed attrezzature, trasporti), sia alla qualità ambientale, alla qualità di fruizione, informazione ed eventi, ecc.

Queste nuove "popolazioni transitorie" esprimono domande non soltanto di servizi turistici e commerciali ma anche di servizi civili e di comunicazione, di attività di intrattenimento e di accessibilità alle funzioni urbane e esprimono modalità non sempre prevedibili di uso del territorio. Esistono oggi nuove opportunità di visita e di soggiorno: le aree dei parchi tematici (archeologici, minerari, letterari, ecc.) all'interno dei quali possono essere previsti percorsi pedonali per il tempo libero, per il fitness, piste ciclabili e attrezzature ricettive leggere, il litorale urbano e non (waterfront), i servizi urbani specializzati, ecc. Tali spazi, se adeguatamente studiati, 
potranno determinare un riequilibrio delle polarità attrattive delle aree turistiche tradizionali qualora accompagnati da interventi tesi al miglioramento dell'accessibilità e della rete informativa per la mobilità, non solo per le esigenze dei turisti, ma anche per gli stessi cittadini. Larmatura territoriale, intesa come struttura organizzativa gerarchica del sistema insediativo ed infrastrutturale, diviene il supporto su cui si muovono i turisti: regola i punti di arrivo/ ingresso (aeroporti, porti, stazioni) distribuisce i flussi rispetto alle risorse e alle funzioni, organizza l'ospitalità (convenzionale e non convenzionale).

Turismo e trasformazioni territoriali. - Fra i molti territori turistici i territori costieri (marini come lacustri) sono, in una qualche forma, "beni rari" resi limitati nello spazio proprio dalla presenza dell'acqua che ne amplifica le potenzialità ma ne circoscrive fisicamente le superfici d'uso (anche dal punto di vista delle correnti e della meteorologia). Tali territori, da sempre caratterizzati dalla compresenza di grandi risorse (storico ambientali, sociali, ecc.) e di grandi vulnerabilità alla trasformazione (pressioni insediative e speculative, ecc.), possono essere definiti a "sviluppo lento" (Marin, 2005) proprio per la loro difficoltà a reinventare una economia postindustriale. Il turismo è sembrato a molti una opportunità unica, forse troppo "facile" per valorizzare le risorse intrinseche e delineare nel contempo scenari di sviluppo e trasformazione.

Allora la domanda viene spontanea: quale ruolo svolge, o potrebbe svolgere il turismo nelle operazioni di valorizzazione e riqualificazione del territorio costiero ad alta strutturazione storica? E' possibile una interazione direttamente con i temi della trasformazione urbana e territoriale?

"Governare" il turismo non è certo facile, soprattutto tenendo presente la duplice caratterizzazione che lo distingue nel suo impatto sul territorio: da una parte il suo carattere di sistema chiuso con proprie leggi di comportamento, propri valori di riferimento 
e proprie convenienze; dall'altra la configurazione di un sistema aperto alla città e al suo territorio che chiede di valutare in tempi reali le condizioni di offerta per tutelare i valori e il consumo delle risorse di cui si compone.

In quest'ottica termini come conservazione e valorizzazione non sembrano più antitetici, ne sotto il profilo culturale, ne sotto quello della pianificazione e della programmazione dello sviluppo economico; rimane però molto rischioso sottovalutare i valori complessi del territorio costiero quando si sposta, troppo facilmente e con superficialità, l'attenzione solo sul "possibile" consumo dei beni storici, culturali ed ambientali per il turismo. L'idea di una maggiore permeabilità del territorio sia per gli abitanti che per i turisti è, d'altra parte, alla base di una migliore capacità di fruizione turistica. La riuscita di un intervento di trasformazione sotto il profilo dell'attrazione turistica non sta solo nella realizzazione di "nuove opere" ma nel livello di accessibilità e integrazione funzionale e formale che si sarà in grado di determinare (un'offerta di territorio) e nella capacità di trasformazione che le stesse saranno in grado di indurre nel contesto territoriale di riferimento.

Il ruolo svolto dal settore turistico si può esplicitare in due momenti fondamentali del processo di trasformazione: il momento delle valutazioni strategiche e il momento delle scelte localizzative, e pianificatorie. In entrambi i momenti la volontà di riconfigurare una offerta territoriale costiera significa tendere a determinare una qualità maggiore della domanda (e dell'offerta turistica): il potenziamento della domanda è legato direttamente alla possibilità di valorizzare per le molteplici figure dei visitatori un ambiente gradevole e attrattivo in grado di garantire forme complementari di fruizione del tempo libero e nel contempo potenziare una armatura territoriale strutturante in grado di permettere l'interazione delle risorse e la mobilità dei flussi sul territorio. E' il cambiamento dei modi di fruire il territorio da parte degli stessi abitanti a rappresentare occasione di potenziamento della domanda. Basta pensare alla 
modifica dei rapporti tra tempo libero e tempo di lavoro nella vita quotidiana, all'interesse per una maggiore conoscenza, e quindi cultura sociale ed individuale, che si sta determinando nei confronti del territorio.

L'occasione di una ricerca: la domanda di luogo. - Se il turismo è stato considerato per anni un nemico del territorio, un insieme di attività che genera un'occupazione impropria di suolo, oggi genera domande e opportunità specifiche costituendo una risorsa della pianificazione e della programmazione delle attività sul territorio e occasione di bonifica e restauro oltre che di valorizzazione delle risorse della storia e della natura.

Negli ultimi anni la domanda di "luogo" espressa dalle popolazioni che a vario titolo fruiscono un territorio è profondamente cambiata: al concetto stesso di luogo si è andato gradualmente sostituendo un nuovo rapporto tra continuità e discontinuità dell'abitare. Il ruolo di centralità del territorio stesso non risponde più solo ad una forma di "residenzialità stabile" arrivando ad integrare nuovi flussi e nuove forme d'uso in grado di ridefinire il rapporto fra l'abitare, il muoversi, la capacità di fornire/utilizzare servizi, le attività e, soprattutto, il tempo libero.

In questa fase di passaggio da una forma di residenzialità sostanzialmente legata all'apparte-nenza ad "un posto", ad una più complessa e articolata forma d'uso del territorio, cresce l'importanza un nuovo "costruttore di geografie stanziali" che va sottolineato: il turismo, generatore di flussi e relazioni ancora difficilmente interpretabili ma i cui effetti si riflettono in forma diversificata sui consumi individuali e collettivi di territorio.

Tale tema ha rappresentato lo spunto di partenza per la ricerca PRIN/2008 "ITATOUR: Visioni territoriali e nuove mobilità. Progetti integrati per il turismo nella città e nell'ambiente". La ricerca si è avvalsa dell'esperienza di cinque sedi universitarie e ha 
posto in essere un dialogo tra differenti dimensioni disciplinari su questioni inerenti la difficile relazione fra il turismo e il territorio.

Il lavoro ha sviluppato cinque tematiche su cinque territori: il paesaggio, la mobilità, la stanzialità, le interazioni, la gestione. I territori, partendo dal Nord sono: il lago di Como, il Cilento, la valle del Crati, il Val di Noto, la Val di Mazzara, rispettivamente curate da Giovanna Fossa (Politecnico di Milano), Elvira Petroncelli (Università di Napoli Federico II), Mauro Francini (Università della Calabria), Paolo La Greca (Università di Catania), Nicola G. Leone (Università di Palermo). In ciascuno dei luoghi oggetto di studio è stato fatto un convegno con operatori del settore turistico, studiosi di varie discipline e politici locali.

Le principali domande che la ricerca si è posta sono legate al ruolo delle cinque categorie utilizzate per comprendere lo sviluppo del turismo, sintetizzabili nelle ragioni del territorio portatore di paesaggio, mobilità, stanzialità, interazioni, gestione, nel radicamento e sviluppo del turismo. I punti di arrivo interessano gli atti che possono essere messi in opera per dare luogo a forme di uso turistico del territorio adeguati ai tempi.

La tematica del paesaggio ha rappresentato una dimensione necessaria al grande tema del turismo perché spendibile come approccio per la diffusione condivisa di una forte identità e delle "diverse vocazioni" dei luoghi. Il turismo presenta complessi valori di criticità in quanto realtà economica connessa al valore dei luoghi ma offre innegabili economie indotte dal possibile sviluppo.

Se la comunicazione dell'offerta turistica si serve anche del paesaggio utilizzando le sue qualità come dichiarazione lampante di una promessa da mantenere, le imprese del turismo necessariamente si alimentano dello spostamento di popolazione. Per questo le forme della mobilità sono motivo di sviluppo per le economie dei luoghi animati dall'intrapresa turistica. Si verifica in genere che è la domanda a condizionare i trasporti e successivamente la stessa risposta costituisce occasione di incentivazione della 
domanda. La forma e la natura delle infrastrutture del territorio determinano infatti spesso le modalità di sviluppo e la natura del turismo stesso. Per ogni area studio si è teso a comprendere quali fossero le infrastrutture e quindi i vettori della mobilità in grado di determinare un'accessibilità che è premessa indispensabile dell'offerta di territorio.

Si è intesa la stanzialità quale allargamento delle potenzialità del risiedere: al concetto tradizionale di "dimora permanente si è gradualmente sostituito il rapporto tra continuità e discontinuità dell'abitare in una dinamica in cui anche il turismo concorre nel definire geografie nuove di stanzialità nel territorio (Petroncelli, 2012). Chi si trasferisce in un luogo per un certo numero di giorni diventa comunque residente di quel posto per quel tempo in cui vi permane. Ciò comporta che il turista radica in quel luogo le forme che riguardano la sua capacità di vita e chiede, oltre ai servizi che permettono specificatamente la "pratica turistica", un insieme di servizi complementari all'abitazione che spesso si sovrappongono ai servizi per la residenza e configurano una qualità generale dell'insediamento.

Se per il turismo il territorio è un bene radicato e non trasportabile il territorio stesso di fatto si apre a interazioni e funzioni di scambio e integrazione che possono avere o non avere successo in ragione delle differenti forme di turismo. La qualità del territorio, infatti, diviene un attrattore spendibile da sviluppare attraverso azioni che travalicano i limiti della pianificazione tradizionale verso strategie in grado di radicare le attività presenti nel territorio quali occasioni di sviluppo spendibile per il territorio e per il turismo (Urbani, 2004).

In ultimo la pianificazione si è dotata negli ultimi anni di strumenti di controllo generando di fatto una consapevolezza nuova rispetto alle tematiche della gestione e della valutazione, sino a far coincidere le tematiche del piano con quelle più complessive del governo del territorio (Leone, 2013) . Con l'esaurirsi dell'urbanistica 
della crescita edilizia le nuove procedure di pianificazione, valutazione e controllo, oltre che arginare i fenomeni di occupazione di suolo dei territori più sensibili dovranno misurarsi con il compito di ridefinire nuovi scopi delle ragioni urbanistiche e affrontare aspetti e condizioni derivanti dallo sviluppo del turismo oltre che dalla residenzialità, dall'accessibilità ecc. Luultimo tema su cui si è misurata la ricerca ha provato a tracciare un quadro degli strumenti capaci di produrre una reale integrazione tra i livelli classici della tradizione urbanistica e quelli più strategici dell'attività turistica. Si è voluto affermare la centralità della questione territoriale e urbana come specificità della intrapresa turistica (Lozato Giotart, 1994).

Il Lago di Como: Il territorio come materia prima. - "La presenza su un territorio fortemente urbanizzato, come quello lombardo, di numerosi bacini lacuali, con elementi di elevata qualità, dimensioni e conformazioni morfologiche variamente modellate, è una situazione che non ha eguali in Italia e rappresenta un sistema unico anche in Europa." (PTR LOMBARDIA, Documento di Piano, Regione Lombardia, 2010).

L'offerta turistica del contesto territoriale del Lago di Como presenta caratteristiche consolidate, condizionanti dell'intero assetto insediativo e dei luoghi: non si tratta infatti di un territorio da "costruire" per il turismo, quanto da rileggere nella compresenza di offerte turistiche differenziate per proporre integrazioni e trasformazioni innovative in relazione a nuove domande possibili.

Il territorio del Lago di Como (Lario) si sviluppa per 2104 kmq e comprende le provincie di Como e Lecco. Il fascino e la notorietà di questo territorio si riflette nel numero dei visitatori stranieri che con 682.539 arrivi, rappresenta oltre il $60 \%$ del 1.122.079 di visitatori che nel 2010 hanno soggiornato in quest'area. È un territorio ricco di paesaggi suggestivi che riflettono un delicato equilibrio tra l'uomo e la natura, in parte compromessi dalle trasformazioni territoriali degli ultimi decenni, caratterizzato 
da una predominante componente montuosa $(67 \%)$ e da aree collinari della Brianza (28\%) mentre risultano marginali le aree di pianura (4\%). Le aree urbanizzate occupano il 15,3\% del territorio e sono concentrate nelle aree metropolitane di Como, Lecco e in Brianza. Le aree protette coprono il $14 \%$ del territorio; più incisiva, in termini percentuali, la presenza nel Lecchese pari al $18 \%$ mentre nel Comasco le aree protette occupano il 12\% del territorio.

La peculiarità di questo territorio è proprio di essere a un tempo produttore di offerta turistica e un generatore di relazioni interne ed esterne, e quindi di domanda. Accresce la capacità attrattiva la vicinanza con aree di forte sviluppo e di buona accessibilità alle principali infrastrutture di trasporto (aeroporti, ferrovie, autostrade).

La sfida del gruppo di ricerca del Politecnico di Milano è consistita nel proporre la messa in rete del turismo tradizionale del lago con il turismo industriale del contesto territoriale (i distretti di Piccole e Medie Imprese della Brianza e della Valsassina: tessilemoda, legno-arredo, ferro) per ritrovarel'integrazione fra il paesaggio costiero e quello delle prealpi e delle colline brianzole, scoprire sinergie fra la tutela delle coste lacustri, il recupero dei rustici a monte, l'archeologia e la riqualificazione ambientale, rivitalizzando e dando nuovo significato agli antichi tracciati riallacciando l'immagine del lago a quella degli storici percorsi transalpini, da Milano verso i passi dello Spluga e del Bernina, famosi nel medioevo per la via del vino e del sale e celebrati dalla cultura romantica dei primi viaggiatori del Gran Tour che li attraversavano per raggiungere il lago.

A livello territoriale, secondo una prima analisi dei fenomeni che hanno caratterizzato negli ultimi anni le trasformazioni più significative del sistema insediativo, si può sottolineare:

- la crescita degli insediamenti circostanti ai capoluoghi ed il decentramento di attività che hanno configurato i poli centrali di un sistema insediativo complesso 
intorno a Como e Lecco, con la conseguente crescita di mobilità di scambio;

- l'inglobamento nella struttura economica della corona metropolitana milanese, caratterizzata sia da una polverizzazione insediativa e del sistema d'impresa che dallo sviluppo del terziario tradizionale ed avanzato (anche legato alle sedi universitarie di Como e Lecco);

- il passaggio da un modello insediativo policentrico ad un modello diffuso indifferenziato, il conseguente aumento costante e significativo del tasso di motorizzazione;

- l'aumento del livello di reddito e di scolarità, con conseguente incremento degli spostamenti per motivi di lavoro, studio (e anche, perché no, di turismo);

- l'analisi delle regole compositive e delle dinamiche del costruito ha portato a riconoscere le relazioni tra insediamenti e territorio;

- la Brianza, zona di cerniera tra l'area metropolitana milanese e le aree montane e lacuali. La pianura ha mantenuto la storica vocazione policentrica costituita da un mix di centri medi fortemente relazionati ma scarsamente gerarchizzati, molti dei quali dotati di forte identità sociale ed economica poiché sedi di distretti produttivi. Le urbanizzazioni sono caratterizzate da un tessuto edilizio di recente formazione e diversificazione funzionale;

- i capoluoghi e le aree a loro interrelate, massa critica di funzioni e servizi dove sono localizzate le attività economiche a maggior contenuto di innovazione e crescita potenziale, le attività di produzione immateriale, le attività formative e legate alla ricerca che necessitano di punti di riferimento ed accesso alla rete globale;

- l'urbanizzazione lineare del fondo valle lacuale (Lario e Ceresio) con un tessuto edilizio compatto attestato 
lungo gli assi stradali portanti della SS 340 Regina (riva occidentale e verso la Svizzera) e della ex-SS 583 Lariana (sulla riva orientale). Agli insediamenti storici rivieraschi si contrappongono, nella prima fascia collinare, le nuove urbanizzazioni (prevalentemente di seconda residenza), connotate da basse densità $e$ alto consumo di suolo; ne risulta in alcuni casi, una modificazione del paesaggio non sempre compatibile con le condizioni di natura originarie. Il sistema delle ville rivierasche ha trovato nuove forme di utilizzazione (convegnistica e ricettività di lusso) costituendosi come vere e proprie "emergenze";

- i rilievi montuosi a corona del laghi principali, con insediamenti sparsi a vocazione quasi esclusivamente residenziale che si attestano lungo (ed alla fine) delle aste di collegamento che risalgono dal fondovalle. Al lento abbandono degli abitanti originari si sostituisce una nuova popolazione transitoria, proveniente dal bacino regionale, che usa in modo stagionale il patrimonio insediativo esistente.

La principale attrattiva del territorio è certamente costituita dalla molteplicità dei paesaggi che riflettono l'identità e la cultura dei luoghi: dal lago, alle montagne, alle valli si articola un'offerta per svolgere molteplici attività in contatto con la natura e con la storia. 


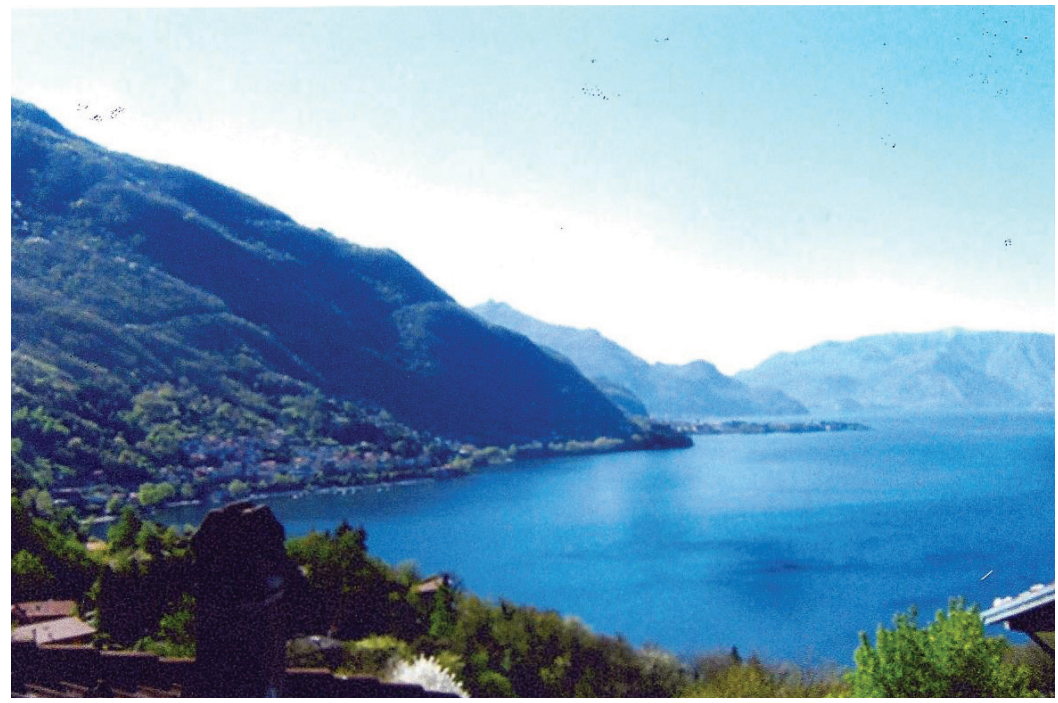

Fig. 1 - Colico, Panorama del Lago di Como. Fonte: foto dell'Autrice

Dall'analisi delle presenze turistiche emerge la forte attrattività di questa destinazione nei confronti del mercato internazionale che risulta prevalente rispetto a quello interno. I dati dell'Osservatorio del STL del Lago di Como confermano infatti che sul Lago i turisti stranieri raggiungono il $78 \%$ della presenza complessiva. Nelle località montane prevale una domanda italiana composta per la maggior parte da flussi turistici interregionali: un turismo di prossimità legato in particolare all'uso di abitazioni private. Il turista che soggiorna in Brianza e in città, italiano o straniero, è invece maggiormente legato a motivazioni di lavoro.

Un territorio turistico dal cuore antico - Il cuore di questa regione è il Lario: sin dal XVIII secolo località interessata dal Grand Tour che stimola l'interesse dei visitatori con le sue ville costiere e il suo microclima mediterraneo. Tra il XVIII e il XIX secolo il Lago di Como diventa la località di villeggiatura 
per l'alta borghesia e la nobiltà milanese e si afferma l'interesse per il paesaggio delle colline della Brianza, caratterizzate dalla presenza dei laghi minori e dai solchi fluviali dell'Adda e del Lambro. A partire dalla seconda metà dell'Ottocento, con l'industrializzazione e lo sviluppo del trasporto ferroviario, cambia il modo di fruire il territorio e, di conseguenza, il paesaggio stesso del Lago. Questo si manifesta in particolare nei centri di maggiori dimensioni (Como, Lecco), in Brianza, e nelle valli (Valsassina, Valle Seveso) che, più di altri territori hanno affrontato il difficile rapporto tra l'industria e la natura, tra la fabbrica e la campagna. Negli stessi anni cambia anche il modo di muoversi e la trama delle infrastrutture si infittisce offrendo nuove opportunità alla frequentazione turistica: la realizzazione del sistema ferroviario, a partire dal 1849 con il completamento del collegamento tra Como e Milano, porta all'apertura delle linee Lecco-Bergamo (1863), Lecco-Milano (1873), Como-Varese (1885) e ComoLecco (1888). Nel 1884 viene completato il tracciato ferroviario Menaggio-Porlezza (oggi dismesso) finalizzato a creare una connessione internazionale tra l'Italia e la Svizzera attraverso il collegamento tra il Lago di Como e il Lago di Lugano.

Nel 1894 viene completata la linea Lecco-Colico che si sviluppa lungo la sponda orientale del Lago e viene inaugurata la funicolare a vapore che mette in collegamento Como a Brunate. Elettrificata nel 1911, la funicolare contribuisce in modo significato allo sviluppo turistico della località collinare grazie anche allo spettacolare panorama su Como ed il Lago che si può ammirare durante il viaggio. Si configura così, all'inizio del XX secolo, un sistema moderno ed integrato di offerta di trasporto per i flussi turistici che ha determinato lo sviluppo del turismo locale nel quale ha un ruolo da protagonista la nuova classe borghese. Sul territorio ed in particolare sul Lago si intensifica così la domanda di nuove ville da parte della borghesia di strutture ricettive e di alberghi. A Como, nel 1899, viene fondata la società italiana degli albergatori. 
Nel 1924 viene aperta l'autostrada Milano-Laghi che avvicina il lago al suo bacino turistico principale, Milano; al flusso dei turisti si sovrappone quello dei visitatori giornalieri. Tra i principali centri turistici segnalati negli anni venti dal TCI, compaiono diverse località del Lario: Cadenabbia, Cernobbio, Menaggio e Bellagio. Si tratta di un turismo primaverile e autunnale. Non sono segnalate località montane sul territorio lariano (che pure iniziano $\mathrm{a}$ svilupparsi) ma solo nella vicina Valtellina.

Grazie anche all'implementazione dell'accessibilità si sviluppa, nel contempo, sia il turismo domenicale, con l'intensificarsi della gita fuori porta, che Il turismo stagionale (soprattutto nel centro lago e sul ramo di Como nei centri turistici di Bellagio, Cernobbio, Tremezzo, Cadenabbia, Moltrasio e Como) principalmente di provenienza estera. Nel dopoguerra, dopo gli anni della ricostruzione, comincia il turismo di massa che, seppur in modo meno incisivo rispetto alle località marittime ed alpine, investe anche la regione lariana e la Brianza. Un indicatore dello sviluppo delle attività turistiche sul territorio sono le presenze negli esercizi alberghieri che, tra il 1955 ed il 1965, passano da 692 mila a un milione e 114 mila con un incremento del $60 \%$ avviando un trend che, nonostante una flessione negli anni settanta, dovuta alla crisi economica, è continuato in modo progressivo facendo registrare nel 2010, 2 milioni e 76 mila presenze negli alberghi e 3 milioni e 18 mila di presenze totali. E' soprattutto lo sviluppo turistico dovuto alle seconde case a generare le trasformazioni più incisive sul territorio e sul paesaggio portando ad un processo di espansione che ha generato tessuti misti turistico-residenziali che si sono estesi prima nelle aree costiere lacustri, successivamente in un limitato entroterra e sui pendii sovrastanti. Lo stesso tipo di sviluppo edilizio estensivo, caratterizzato da villette mono e bifamiliari e piccoli condomini, si ritrova anche in Brianza per i residenti e nelle località montane per le seconde case (Valsassina e in particolare ai Piani Resinelli). 
Parallelamente ai processi di espansione e lottizzazione, nel corso degli anni ottanta e poi in modo più incisivo nei decenni successivi, si sviluppa una maggiore attenzione verso i temi del recupero che coinvolge anche gli spazi destinati alle attività turistiche: rustici e fabbricati storici vengono trasformati in seconde case ma anche agriturismi e bed and breakfast.

Molto incisivo negli ultimi decenni è stato l'impatto delle infrastrutture sul paesaggio: la concentrazione degli investimenti sul trasporto su gomma a discapito di quello su ferro ha determinato situazioni di congestione, in particolare nei fine settimana, lungo le principali direttrici (si pensi in particolare alla SS36 e all'autostrada dei laghi) e determinato la necessità di continui interventi di adeguamento e potenziamento del sistema stradale con inevitabili impatti sull'ambiente e sul paesaggio (Fossa, 2006).

Con la dismissione e la riconversione di molte strutture industriali, l'immagine del territorio è mutata, si è rafforzato il ruolo terziario e turistico ed il rapporto con l'area metropolitana milanese; a livello internazionale il Lago di Como resta un luogo emblematico di sintesi tra natura, storia e cultura, sede di prestigiose associazioni culturali (FAI, balbianello), di meeting economici internazionali (Villa d'Este, Cernobbio) e residenza dei divi del cinema (Clooney, Lesmo).

Recentemente le provincie di Como e Lecco e il STL del Lago di Como sono stati promotori di interessanti progetti promossi orientati allo sviluppo della mobilità sostenibile del miglioramento della fruibilità delle sponde e della realizzazione di greenway,: il progetto "Sul Lago di Como senzauto: infrastrutture e servizi per la mobilità dolce" e il Piano della rete ciclabile della provincia di Lecco.

L'offerta turistica: risorse, opportunità e ospitalità. - Il Lago ha condizionato fortemente l'immagine romantica e pittorica e l'organizzazione degli spazi all'intorno e il loro uso anche ai fini turistici. La stretta fascia rivierasca, la mancanza di un fondovalle 
e le limitate disponibilità di spazi vengono ricuciti dal sistema delle infrastrutture viarie e ferroviarie che ritagliano articolati e suggestivi tracciati peri lacuali litoranei. Il comparto turistico è oggi l'elemento caratterizzante dell'economia: le strutture ricettive, di piccole e medie dimensioni, si sono sviluppate sul territorio in forme disordinate. In particolare, lo sviluppo di un turismo affidato alla ricettività in seconde case ha ridotto gli spazi liberi e creato strutture insediative deboli, con una limitata dotazione di servizi o soggette a crisi stagionali per l'aumento delle presenze turistiche.

Nel territorio montano il settore turistico, più degli altri, rappresenta le contraddizioni e gli squilibri dello sviluppo: anche se costituisce indubbiamente una risorsa economica importante, rimane caratterizzato ad una selezione della domanda rivolta agli sport invernali o al fenomeno delle seconde case, stentando a coinvolgere una offerta più vasta e non riuscendo a proporre una integrazione con altre attività, in particolare l'agricoltura, e l'affermarsi di un turismo culturale diffuso che si potrebbe appoggiare anche sull'offerta di parchi e aree protette.

La vicinanza con Milano e con il suo polo fieristico si riflette in una significativa presenza di questo tipo di turismo in Brianza $\mathrm{e}$ in alcune località che si affacciano sul Lago. Tali presenze si intensificano e si estendono al territorio in occasione di grandi eventi (il Salone del Mobile o la Settimana della Moda): l'Expo 2015, con i suoi 20 milioni di arrivi previsti, rappresenterà una grande attrattiva turistica per l'intera regione metropolitana milanese e per i "laghi di Milano". Non meno importante ai fini del turismo d'affari è il contesto economico che comprende due tra i distretti industriali più grandi d'Italia, in termini di numeri di addetti delle unità manifatturiere, il distretto del tessile e dell'abbigliamento di Como e della meccanica di Lecco. Ad essi si affianca la significativa presenza del distretto del mobile e dell'arredo della Brianza. Secondo un'indagine a campione elaborata dall'Osservatorio del Turismo, gli arrivi per motivi di lavoro sono pari al 19,3\% del totale. 
In Brianza si stanno sviluppando nuove domande turistiche che coinvolgono in modo sinergico attività produttive, di ricerca $\mathrm{e}$ formazione e che, sebbene attualmente ancora limitate in termini quantitativi, offrono interessanti opportunità per lo sviluppo del turismo in integrazione con l'evoluzione sostenibile del territorio. $\mathrm{Si}$ tratta del "turismo industriale tematico" e del "turismo formativo". Il primo vede la cooperazione tra operatori turistici e imprenditori nella creazione di pacchetti turistici finalizzati a far conoscere direttamente ai clienti non solo l'azienda e i processi di produzione ma anche il territorio. Il secondo è invece legato al radicarsi dell'Università sul territorio (Politecnico di Milano e Università dell'Insubria) e al processo di internazionalizzazione che sta investendo le attività formative.

I Capoluoghi generano invece un'offerta turistica legata sia alla fruizione del patrimonio storico che alla domanda di funzioni, servizi specialistici e centri di ricerca e formazione. Di provenienza prevalentemente straniera $(60 \%)$ uniscono alle visite culturali (ville, centri storici), gite di carattere naturalistico ambientale (la Spina Verde di Como).

\begin{tabular}{|l|c|c|c|}
\hline Indicatore & $\begin{array}{c}\text { PROVINCIA } \\
\text { LECCO }\end{array}$ & $\begin{array}{c}\text { PROVINCIA } \\
\text { COMO }\end{array}$ & TOTALE (C+L) \\
\hline $\begin{array}{l}\text { Esercizi alberghieri } \\
\text { variazione } 1999 / 2009\end{array}$ & $0,9 \%$ & $-16,2 \%$ & $-10 \%$ \\
\hline $\begin{array}{l}\text { Esercizi extra- } \\
\text { alberghieri var. } \\
1999 / 2009\end{array}$ & $1164 \%$ & $131,6 \%$ & $239,5 \%$ \\
\hline $\begin{array}{l}\text { Aziende agrituristiche } \\
\text { var.e } 1999 / 2009\end{array}$ & $92,8 \%$ & $170 \%$ & $132,7 \%$ \\
\hline
\end{tabular}

Tab. 1 - Offerta ricettiva, dati aggregati per provincia, variazione 1999/2009, Fonte: STL 
Dall'analisi dei dati di sintesi sull'offerta ricettiva e dal confronto con i dati della variazione 1999/2009 si possono individuare alcune linee di tendenza:

- il settore della ricettività convenzionale è caratterizzato da una presenza di alberghi di 4 e 5 stelle nell'ambito del Centro Lago, nei capoluoghi e nella Brianza legati ad un turismo prevalentemente di affari e culturale. Le strutture ricettive di 3, 2 e 1 stella sono invece distribuite sul territorio in modo più omogeneo (con concentrazioni in Centro Lago, Brianza, Alto Lago e Valle Intelvi);

- il settore della ricettività non convenzionale vede invece una distribuzione di strutture di grandi dimensioni (villaggi e campeggi) concentrate in prevalenza nell'Alto Lago e nell'area del Ceresio; strutture di medie dimensioni (agriturismi, ostelli e case per ferie) concentrate in Alto Lago ed in Brianza, strutture di piccole dimensioni (affittacamere, b\&b, case per vacanze) concentrati in Alto Lago, Brianza e Capoluoghi;

- c'è stata una riduzione complessiva delle strutture ricettive tradizionali (soprattutto in provincia di Como) e un aumento (in alcuni casi una "fondazione" della ricettività non convenzionale e delle aziende agrituristiche;

- la significativa riduzione delle strutture ricettive convenzionali di livello basso (1 e 2 stelle) è stata determinata anche dall'aumento e dall'articolazione dell'offerta ricettiva non convenzionale.

Il Sistema Turistico Lago di Como: ambiti territoriali e prodotti turistici. - Il Sistema Turistico Lago di Como è stato istituito, seppur in fase embrionale, fin dal 2003, quando le Province di Como e di Lecco, dapprima separatamente poi congiuntamente, cominciano a ragionare sulla necessità di creare una forma di 
coordinamento delle iniziative pubbliche in campo turistico. Questa prima riflessione ha trovato un supporto normativo nella LR 8/2004 "Norme per il turismo in Lombardia", che, recependo in maniera originale la Legge Quadro nazionale, invita gli Enti locali e gli imprenditori alla costituzione dei sistemi turistici. Nel novembre del 2005 con la DGR VII/1159 del 23/11/2005 è stato riconosciuto ufficialmente il Sistema Turistico Lago di Como come strumento di Governance. La sua azione si concretizza nella predisposizione e realizzazione del Programma di Sviluppo Turistico. Si tratta di un insieme di progetti integrati che si sviluppano nell'arco di un triennio e si prefiggono di favorire le sinergie fra gli attori del Sistema, risolvendo le problematiche principali del turismo lariano.

Attraverso la lettura della struttura morfologica del territorio e della dotazione turistica il STL ha proposto una articolazione in dieci ambiti territoriali:

- la Valle Intelvi, con indice di notorietà contenuto ma con in atto una prima riqualificazione turistica;

- le Alpi Lepontine, turisticamente molto poco sviluppate e deboli, fanno parte del prodotto turistico dell'Alto Lago(mercato turistico tedesco);

- la Valsassina, che pur vantando un passato turisticamente rilevante non sembra avere attualmente grande capacità attrattiva;

- la Valle San Martino, dove ad un calo del turismo di villeggiatura corrisponde un aumento del turismo d'affari grazie alla posizione lungo l'asse Bergamo-Lecco;

- il Triangolo Lariano che fatica ad affermare la propria immagine presso i mercati stranieri, tre cresce il turismo sportivo regionale e metropolitano; 


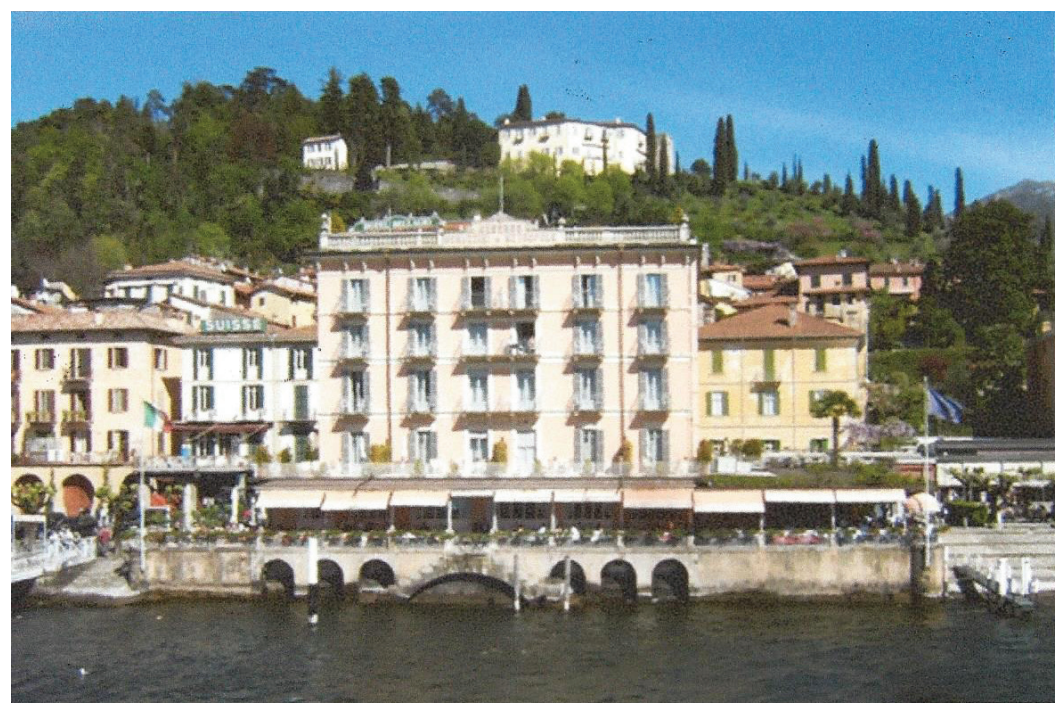

Fig. 2 - Bellagio, il waterfront. Fonte: foto dell'Autrice

- il Basso Lago, caratterizzato da un'ottima notorietà e strutture di eccellenza, che accusa negli ultimi anni una contrazione della durata media del soggiorno;

- il Centro Lago, caratterizzato da un indice di notorietà e un patrimonio di offerta turistica solido, e da una crescente permanenza media;

- l'Alto Lago, sostanzialmente differente dal resto del bacino, offre un prodotto più vicino allo sport e al turismo naturalistico;

- il Ceresio, legato al versante vallivo che si affaccia sul Lago di Lugano, interessato soprattutto da turismo straniero;

- i Capoluoghi, Como e Lecco, interessati da una commistione di forme fruitive turistiche. La diminuzione del soggiorno medio è indice di una nuova vocazione business, mentre l'andamento delle presenze nel corso 
dell'anno delinea un andamento costante con una sommità in agosto;

- la Brianza, caratterizzata da una vocazione turistica legata agli affari.

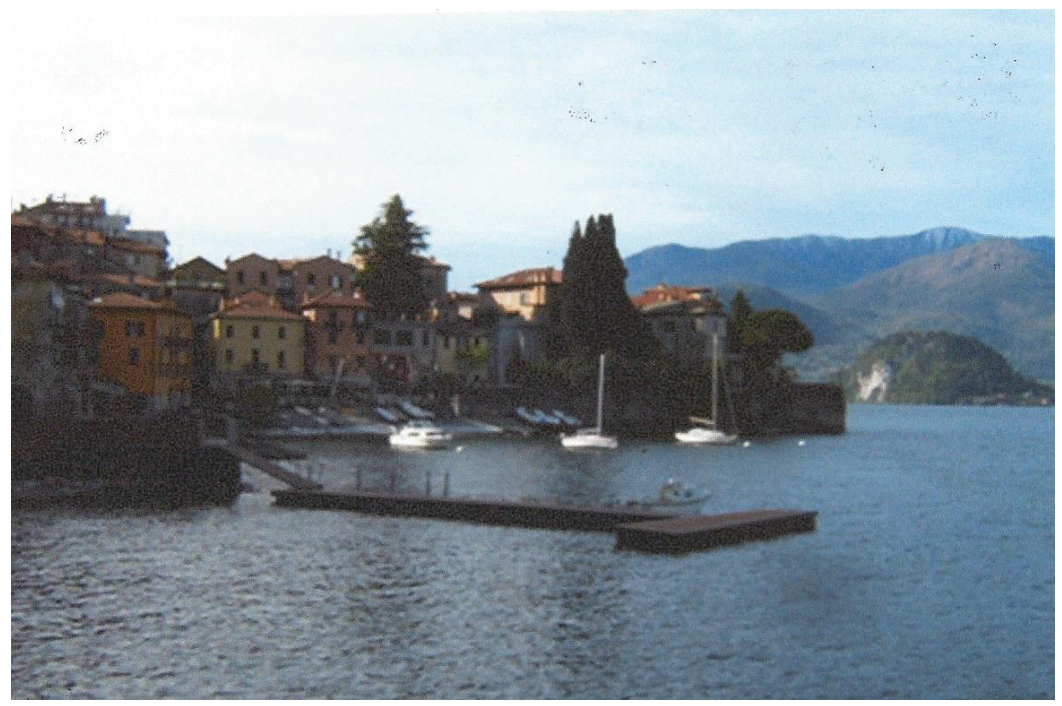

Fig. 3 - Varenna, Riva dei Marmisti. Fonte: foto dell'Autrice 


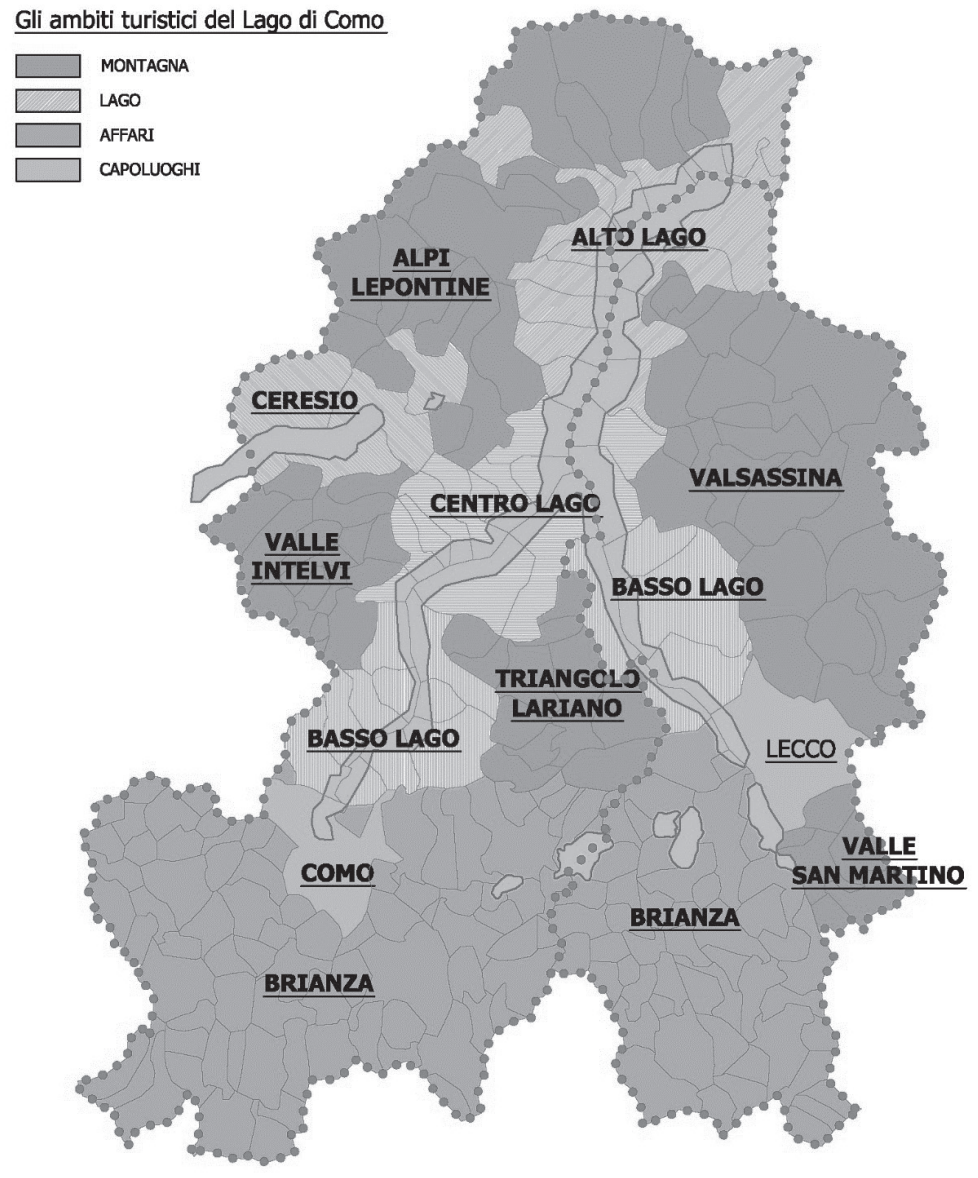

Fig. 4 - Gli ambiti turistici del lago di Como. Fonte: elaborazione dell'Autrice, 2012 


\begin{tabular}{|c|c|c|c|c|}
\hline Ambiti & $\begin{array}{l}\text { Numero } \\
\text { Comuni }\end{array}$ & $\begin{array}{c}\text { Popolazione } \\
\text { (ab.) }\end{array}$ & $\begin{array}{c}\text { Densità (ab/ } \\
\text { Kmq) }\end{array}$ & $\begin{array}{c}\text { Superficie } \\
(\mathrm{Kmq})\end{array}$ \\
\hline AFFARI & 134 & 629.103 & 811 & 721,13 \\
\hline Brianza & 134 & 629.103 & 811 & 721,13 \\
\hline CAPOLUOGHI & 2 & 133.377 & 1.549 & 83,27 \\
\hline $\begin{array}{l}\text { Como } \\
\text { Lecco }\end{array}$ & $\begin{array}{l}1 \\
1\end{array}$ & $\begin{array}{l}85.263 \\
48.114\end{array}$ & $\begin{array}{c}2.107 \\
991\end{array}$ & $\begin{array}{l}37,34 \\
45,93\end{array}$ \\
\hline LAGO & 44 & 91.177 & 168 & 563,34 \\
\hline $\begin{array}{l}\text { Alto lago } \\
\text { Basso lago } \\
\text { Centro lago } \\
\text { Ceresio }\end{array}$ & $\begin{array}{c}13 \\
14 \\
13 \\
4\end{array}$ & $\begin{array}{c}29.022 \\
34.550 \\
17.798 \\
9.807\end{array}$ & $\begin{array}{l}197 \\
178 \\
138 \\
132\end{array}$ & $\begin{array}{c}169,66 \\
180,69 \\
136,81 \\
76,18\end{array}$ \\
\hline MONTAGNA & 72 & 81.498 & 146,18 & 736,50 \\
\hline $\begin{array}{l}\text { Alpi Lepontine } \\
\text { Valle San Martino } \\
\text { Valle Intelvi } \\
\text { Valsassina } \\
\text { Triangolo Lariano }\end{array}$ & $\begin{array}{c}17 \\
6 \\
13 \\
23 \\
13\end{array}$ & $\begin{array}{l}11.411 \\
9.543 \\
23.487 \\
21.929 \\
15.128\end{array}$ & $\begin{array}{c}54 \\
664 \\
98 \\
71 \\
206\end{array}$ & $\begin{array}{c}237,94 \\
84,42 \\
37,40 \\
293,49 \\
83,25\end{array}$ \\
\hline
\end{tabular}

Tab. 2 - Articolazione degli ambiti del STL per numero di comuni, superficie e popolazione. Fonte: ISTAT, 2010, elaborazione dell'Autrice

Il STLC può essere facilmente letto attraverso la lente del prodotto prevalente proposta dall' Istat. Il concetto di “prodotto turistico prevalente" è presente in tutte le analisi del fenomeno turistico come l'insieme di beni e servizi di un territorio che, messi a sistema, compongono un'offerta in grado di rispondere alle esigenze di specifici segmenti della domanda turistica. In base a questa classificazione, si assume per ogni porzione di territorio analizzata (regioni, province, città, etc...) che il prodotto che genera maggiori presenze sia l'unico prodotto turistico dell'area in questione.

I prodotti turistici dovrebbero quindi essere in grado di riassumere la molteplicità dei flussi turistici che sono interessati all'area: facendo un passo in più, divengono prodotti complessi 
legati alle risorse e alle competenze delle imprese sul territorio la cui offerta non può essere isolata, ma combinata in un sistema integrato a rete.

Il Programma di Sviluppo Turistico del STL 2009-2011 definisce il prodotti turistici come tipologie di offerte di esperienze turistiche (strutturate o non strutturate) secondo un modello di fruizione potenzialmente realizzabile in una dimensione di filiera verticale che risponde ad una nicchia di domanda specializzata. Esperienze intese come una serie di servizi che vengono assemblati dal turista finale in base alle sue capacità di costruzione dell'esperienza turistica. Il Programma, in accordo con quanto proposto dall'ONT (ONT, Analisi dei prodotti turistici, 2011), definisce il STL Lago di Como come una destinazione multiprodotto articolando l'offerta in tre macro-prodotti:

- il Lago, meta di turismo leisure e relax di media durata;

- la Montagna, meta di turismo sportivo e di villeggiatura;

- la Brianza, meta di turismo d'affari.

A cui si aggiunge un'ulteriore Area anche in relazione alla domanda generata dai servizi di livello superiore e dall'università: i Capoluoghi, meta di turismo leisure e d'affari.

Ciascuna di queste aree-prodotto è caratterizzata da un'offerta diversificata in termini di infrastrutture e da una domanda altrettanto diversificata in termini di provenienza, preferenza e capacità di spesa. 


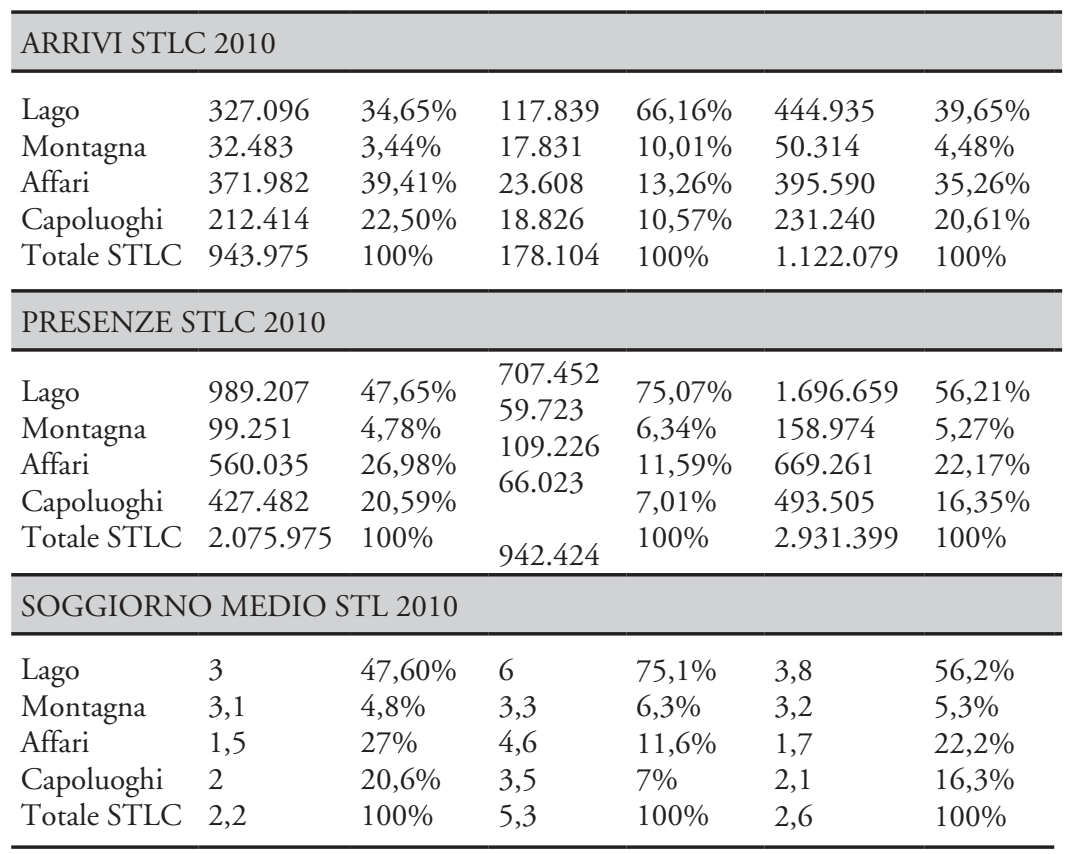

Tab. 3 - Distribuzione dei flussi turistici per aree. Fonte: Osservatorio STLC su dati Uffici Statistici Province di Como e Lecco. Fonte: elaborazione dell'Autrice

L'Area Lago può essere definita da sempre "locomotiva trainante" del STLC in quanto registra oltre il 40\% degli arrivi ed il 50\% delle presenze rispetto all'intero territorio. Frequentata in misura maggiore da turisti stranieri (sono oltre il 70\%) che scelgono di farvi una vacanza per motivi leisure e relax, in quest'area sono presenti strutture ricettive di elevata qualità per gli amanti del turismo lusso (i quattro hotel 5 stelle del STLC si concentrano tutti nel basso-centro Lago) ma anche molti campeggi (nell'alto Lago) per gli amanti del turismo "all'aria aperta".

In ogni caso sia gli italiani che gli stranieri prediligono soggiornare nelle strutture alberghiere dell'area. Nel corso degli ultimi cinque anni (dal 2007 al 2011) gli arrivi e le presenze sono cresciuti di oltre il 12\% (gli arrivi sono passati da 437.903 a 492.020 
e le presenze da 1.600 .525 a 1.803.773); la tendenza positiva è da attribuirsi totalmente all'ottima performance dei mercati stranieri, cresciuti in modo costante nel corso degli anni. Il numeri degli Italiani si è mantenuto pressoché costante nel tempo, con un picco negativo solo a cavallo del 2008 e 2009, periodo di inizio della crisi economica che ha investito l'intero Paese.

L'Area Montagna è il prodotto meno forte del STLC in quanto registra i flussi più contenuti, in termini assoluti, sia di arrivi che di presenze. Come tradizione è frequentata in misura maggiore dagli Italiani anche se il divario con le presenze straniere si sta riducendo anno dopo anno (entrambe le tipologie di turisti preferiscono soggiornare di gran lunga presso le strutture alberghiere).

Nell'arco degli ultimi cinque anni, infatti, si è assistito ad un lento riposizionamento della domanda interna ed internazionale: arrivi e presenze degli Italiani sono lentamente diminuiti (nel 2007 gli arrivi erano 29.331 e le presenze 116.117; nel 2011 si sono registrati 26.566 arrivi e 90.064 presenze), quelle degli stranieri risultano in costante crescita (dal $2007 \mathrm{al} 2011$ gli arrivi sono passati da 15.941 a 25.769 e le presenze da 39.705 a 64.357). Ovviamente la contrazione degli Italiani, oltre a testimoniare delle reali problematiche interne alla domanda nazionale, potrebbe essere influenzata dalle situazioni atmosferiche più o meno favorevoli registrate nei diversi anni, che pesano sulla scelta dei short break dei turisti di prossimità. La Montagna è infatti un tipico prodotto stagionale, caratterizzato da un picco dei flussi turistici in estate, ed altamente influenzato dalle condizioni climatiche. 


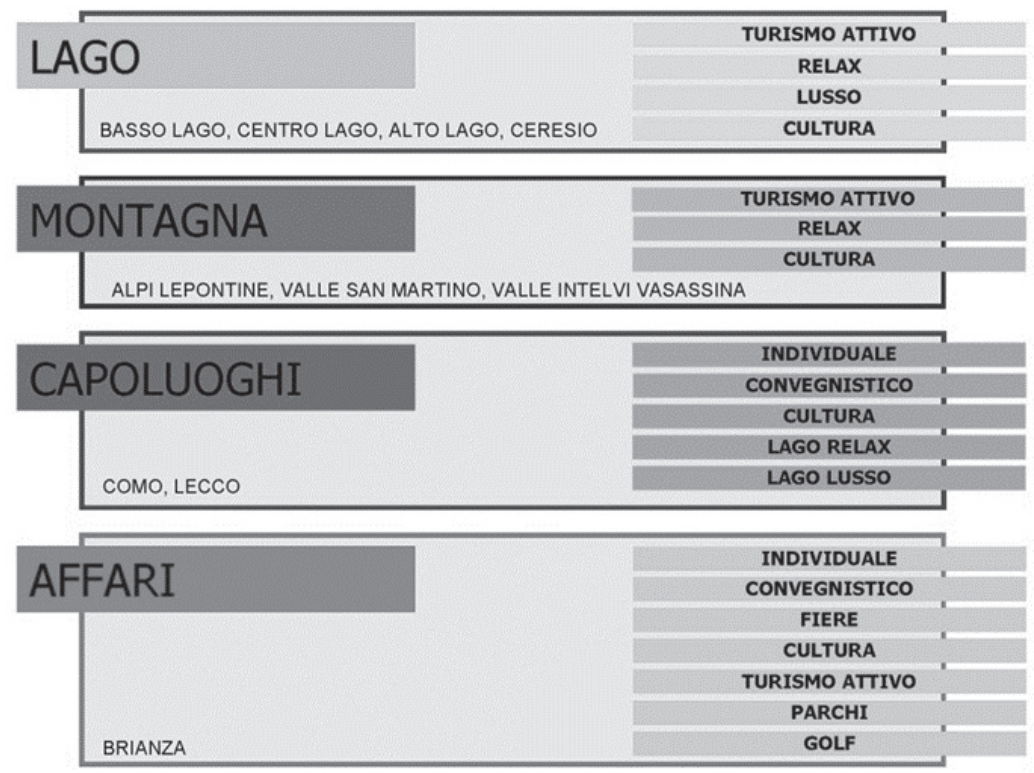

Fig. 5 - I prodotti turistici del lago di Como. Fonte: elaborazione dell'Autrice, 2012

L'Area Affari (territorio della Brianza) è il secondo prodotto più "acquistato" all'interno del STLC (dopo l'Area Lago). I turisti di questarea, avendo come motivazione prevalente il viaggio business, preferiscono alloggiare presso strutture ricettive alberghiere di fascia medio alta. Attualmente risulta ancora maggiore la frequentazione da parte degli Italiani anche se il numero degli stranieri è in continua crescita e si avvicina sempre più a quello dei nostri connazionali.

La Brianza negli ultimi anni ha fatto registrare le crescite più forti e continuative all'interno del STLC (dal 2007 al 2011 gli arrivi sono passati da 275.883 a 430.184 e le presenza da 498.804 a 727.609): italiani e stranieri sono aumentati in modo considerevole non solo negli hotel, ma anche presso le strutture complementari. Questi dati sembrerebbero delineare come all'interno dell'Area Affari le strutture di accoglienza si stiano orientando sempre più ad accogliere non solo la tipica domanda business ma anche a quella 
legata allo svago. Anche la permanenza media conferma sempre più la compresenza di due tipologie di domanda (affari e leisure): mentre presso gli esercizi alberghieri il soggiorno risulta tipico di un turismo business, inferiore quindi ai due giorni $(1,6)$; negli esercizi complementari la permanenza media supera i 3 giorni segno di una presenza di clienti interessati prevalentemente allo svago.

Le due città Capoluogo (Como e Lecco) si caratterizzano per la compresenza di turismo d'affari e leisure, la permanenza media si attesta a 2,1 giorni. Nel corso degli ultimi anni si è assistito ad una graduale diminuzione di turisti Italiani, mentre il numero degli stranieri, dopo un momento di crisi vissuto nel 2008 e 2009, ha ricominciato a crescere, in particolar modo negli hotel: dopo alcuni anni in cui la domanda sembrava, quindi, orientarsi verso modalità di soggiorno meno costose e più "spartane", nell'ultimo periodo si sono osservati i primi cenni di riposizionamento verso l'alto.

Urbanistica e turismo: la domanda e l'offerta di territorio. - Il turismo è considerato da anni come una forma impura di occupazione di suolo, un valore antieconomico difficilmente spendibile nelle pratiche di governo del territorio, considerato per lo meno come un "disvalore non dimensionabile", eventualmente da aggiungere alle altre funzioni prettamente urbane. La necessità di "risolvere" le attività del secondario, della residenza stabile e dei servizi (i famigerati standard), ha di fatto escluso un settore importante e vitale dagli obiettivi del pianificare. La ricerca ITATOUR ha avuto quale punto di partenza il trovare forme di interazione fra turismo e territorio abbandonando le posizioni tradizionali dello zoning verso nuove opportunità e spendibilità offerte dal settore turistico per lo sviluppo del territorio pur nella "continuità di un pensiero che possiede storie, impegni, volontà e capacità di lavoro" (Leone, 2012).

Per poter "girare pagina" è stato necessario ridefinire la relazione, spesso complessa, fra domanda e offerta (di territorio, di turisti, di sviluppo) e quindi fra imprenditori (investitori e operatori 
turistici), fruitori (turisti sia stanziali che giornalieri) e, in forma trasversale, amministratori. Questa relazione sta, pur con una certa lentezza, modificandosi e articolandosi sempre più. A seguito anche delle recenti trasformazioni sociali, economiche e produttive, l'offerta di territori turistici è oggi aumentata grandemente fino ad essere maggiore della domanda stessa portando ad una competitività fra territori e all'articolazione in segmenti di offerta differenziati: l'utente, cliente virtuale, può scegliere tra le diverse proposte arrivando a ridefinire le caratteristiche qualitative e quantitative delle proposte stesse (turismo culturale, naturalistico ed ambientale, ecc). Questo comporta una maggior attenzione alla domanda posta dal consumatore anche in termini di qualità aggiunta dei servizi, dell'accessibilità, dell'ambiente e del territorio nel suo complesso, generando nuovi tipi di domanda, articolati in quanto connessi:

- da una parte nella definizione della qualità "generale" dell'offerta non solo di ricettività (servizi ed attrezzature, trasporti, ecc.);

- dall'altra nella ricerca di una qualità ambientale, di fruizione, informazione ed eventi, ecc.

Il concetto di turismo varia a seconda di chi lo usa. Per un imprenditore turistico il turismo è "un insieme integrato di servizi di composizione variabile, il cui nucleo centrale caratterizza la produzione e il tipo di azienda turistica che lo offre". Per un turista il turismo "è un insieme di fattori ambientali e strumentali nel quale confluiscono gli elementi d'attrazione, i servizi e le facilities, gli elementi d'accesso alla destinazione, l'immagine della destinazione, l'informazione." (Casarin, 1996).

La prospettiva del turista (domanda) e la prospettiva dell'operatore turistico (offerta) sono opposte e complementari: 
- gli imprenditori fanno riferimento al livello dei servizi turistici secondo una dimensione verticale (di servizio), focalizzando l'attenzione alle fasi della filiera di produzione ed erogazione dei servizi che stanno a monte ed a valle dell'offerta turistica;

- il turista fa riferimento al livello logico dell'esperienza, secondo una dimensione orizzontale, sintesi sistemica di servizi offerti da diversi soggetti, non solo privati.

La recente graduale articolazione della "domanda turistica" del Lago sta portando ad una diversificazione in una molteplicità di forme che ancora in parte sfuggono a molti degli operatori turistici (al turismo tradizionale alberghiero si affianca il turismo non convenzionale meno definibile nei contorni normativi nonché di controllo di gestione): sono aspetti di cui tenere conto per le potenziali positive ricadute sociali ed economiche ma che vanno valutati attentamente per i rischi che possono comportare con politiche non attente alle ricadute sociali ed urbanistiche e alla loro capacità o meno di divenire fatti permanenti del cambiamento o rimanere solo segni effimeri.

Se il territorio del Lago, "turisticamente costruito" costituisce da la "materia prima" per lo sviluppo dell'intero STL i beni e le risorse che determinano tale capacità d'attrazione non sono "esclusivamente" orientati al "turista" ma, al contrario, possono riferirsi ad una platea molto più vasta di utenti (abitanti, city user, ecc.) creando interconnessioni complesse e spesso conflittuali.

Per una gestione equilibrata del territorio, sia sotto il profilo urbanistico che del settore turistico, appare evidente pensare non tanto all'aumento dell'offerta, quanto alla qualificazione del patrimonio esistente sia attraverso specifiche azioni di recupero, che attraverso la messa a punto di una rete di offerta qualificata di servizi (commercio legato ai centri produttivi, enograstronomia, ecc.) e di accessibilità. A questo obiettivo principale si affiancano una serie di corollari: 
- la varietà del territorio del lago, essendo esso costituito da un insieme di attività, forme fruitive, competenze e offerte a target diversificati di cui tener conto per la differenziazione dell'offerta;

- la gestione più che il controllo, essendo il settore turistico essenzialmente privato, e quindi non completamente controllabile da chi gestisce le azioni di pianificazione e programmazione;

- la valorizzazione della non riproducibilità delle sue risorse: si vogliono intendere quelle problematiche di sfruttamento del territorio che influenzano la capacità di sostentamento del territorio stesso e, in un'ottica turistica, la perdita di attrattività sul mercato;

- la contestualizzazione, in quanto il prodotto turistico non può essere separato dalla propria collocazione territoriale.

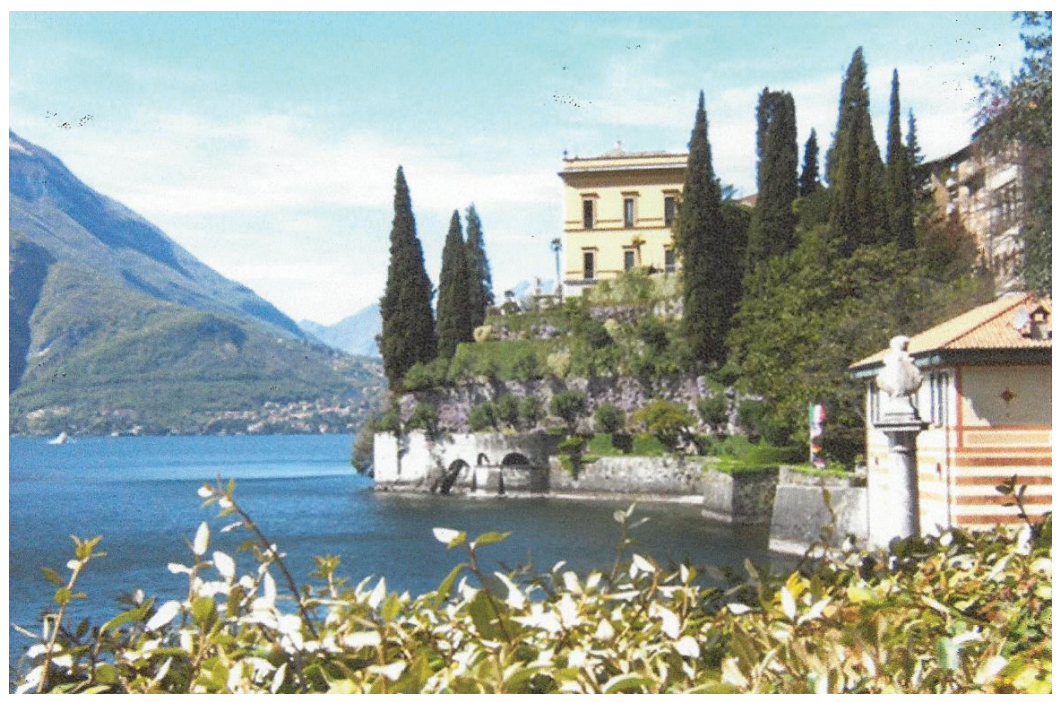

Fig. 6 - Varenna, Villa Cipressi. Fonte: foto dell'Autrice 
La prospettiva di sviluppo e di valorizzazione del territorio "turistico" si basa sul riequilibrio della relazione fra l'offerta e la domanda di residenzialità secondo alcune linee di indirizzo:

- la prima, la più evidente ed immediata, è la ridefinizione delle forme insediative e dei servizi ad esse collegate lavorando sulla capacità attrattiva del territorio stesso, sulla disponibilità di spazio e sulla predisposizione di specifiche condizioni favorevoli (ad es. presenza di infrastrutture, di efficienza nella P.A., di dinamismo imprenditoriale, etc.);

- la seconda è relativa alla valorizzazione del significato simbolico del territorio come luogo: una relazione bidirezionale in grado di assegnare un valore aggiunto agli elementi dell'offerta (l'industria, l'artigianato, l'enogastronomia, ecc.) riaffermando il ruolo comunicativo e promozionale del prodotto turistico nell'appartenenza ad una determinata porzione territoriale (una sorta di "marchio"). Ciò, attraverso il rafforzamento dei caratteri identitari in grado di consolidare e differenziare l'offerta rispetto ai territori concorrenti, facilitandone nel contempo l'accesso, sia sotto il profilo logistico - materiale che informativo;

- la terza linea concerne l'aspetto turistico per eccellenza e riguarda la visita del territorio, che si basa sulla capacità continua di rispondere alla "domanda" in continua trasformazione e alla rigenerazione dei flussi turistici sul territorio stesso.

Dall'azione combinata di queste linee di approccio scatursce un nuovo disegno degli elementi di narrazione dei luoghi in grado di ridefinire i termini di una offerta che non sia solo legata 
all'imprenditorialità ma alla reale ed efficace capacità di risposta della gente che vi vive ed opera.

Ancora ricerca, ancora territorio. - La partenza e lo sviluppo di una ricerca che coinvolge più sedi universitarie non è mai semplice: si ereditano conoscenze, presupposti, concetti che si devono far colloquiare; il ritmo dettato dalle scadenze dei seminari e la necessità di coordinamento e confronto fra le unità spesso privilegia i contenuti metodologici e allontana i territori. Nel portare avanti la ricerca ITATOUR si è voluto sviluppare l'osservazione diretta della realtà dei territori studiati senza abbandonare cultura, contenuti e capacità tecniche specifiche. "Lattivazione dei seminari nei territori oggetto di studio ha permesso di vedere, ascoltare, capire i differenti modi in cui il turismo si manifesta in questi luoghi, ma anche di confrontare modalità di approccio delle cinque unità operative." (Leone, 2012). Questo ha permesso di mantenere la sostanziale "unità del sentire" della partenza sviluppando alcune utili differenze.

Le tematiche delle cinque unità operative intorno alle categorie scelte per lavorare sulle aree di studio (il paesaggio, la mobilità, la stanzialità, le interazioni, la gestione) si sono allora arricchite di argomentazioni fortemente connesse alla natura dei territori studiati. La ricerca ha portato a comporre un racconto di luoghi capace di fornire una "ragione sociale nuova a territori antichi"( Leone, 2012) trovando alcune possibili soluzioni su come modificare alcuni aspetti della tradizione culturale dell'urbanistica e definire un nuovo rapporto con il turismo "nell'apparenza marginale, invece affascinante quanto difficile da affrontare" (Imbesi, 2012).

D'altra parte da sempre la disciplina urbanistica ha mantenuto insieme una doppia natura:

- una tecnica e legale di regolamentazione del suolo e degli edifici, fondamentale per la pratica ordinaria di 
pianificazione che però se lasciata sola perde gli scopi sociali che la animano;

- un'altra, previsionale, ovvero capacità di interpretare il presente per intravedere e quindi aiutare a determinare il futuro; un'assunzione di responsabilità importante che si traduce nel delineare visioni, scenari di sviluppo "strutturale" in cui muoversi per la valorizzazione del territorio.

E' in questa "seconda" natura che va cercata una interazione nuova con il settore turistico, un suo ambito di riconoscimento e di integrazione, pur nel mantenimento di una autonomia nel delineare le convenienze turistiche (localizzative, aggregative, funzionali, ecc.) tipiche di un settore prevalentemente ad investimento privato.

Non si tratta di pensare solo a distretti funzionali per lo svolgimento dell'attività turistica, spesso avulsi dal territorio: la ricchezza di suggestioni che ci hanno offerto i territori studiati (o meglio dire osservati) è costituita proprio dal mix di offerte di attrezzature di natura diversa e non dalla rigida separazione funzionale tra le attività. Si tratta perciò di tendere a definire, nei progetti di intervento, le possibili compenetrazioni tra caratteri ed esigenze diverse spesso non direttamente legate al turismo ma da questo fruibili attraverso un adeguato marketing, contribuendo così a realizzare una offerta alternativa al tradizionale sistema litoraneo. I progetti pilota presentati in questo programma rappresentano infatti uno dei modi possibili attraverso cui correlare e mettere a "sistema" risorse ambientali storiche e culturali, da una parte, e attrezzature territoriali e urbane dall'altra.

La capacità dei territori di preservare la complessità e il valore del patrimonio culturale locale nei processi di trasformazione per la fruizione turistica scaturirà dalla compenetrazione di due aspetti: da una parte la riconfigurazione e la riappropriazione dell'identità locale dei territori turistici, dall'altra la necessità di proiettarsi in 
modo dinamico in un "circuito" territoriale allargato per configurare una rete di offerta integrata ma diversificata.

Nella ricerca di un accordo armonico fra turismo e territorio c'è infine un ultimo aspetto, non meno importante, che è quello di stimolare la crescita di una cultura turistica del territorio. Una cultura che sappia superare gli adattamenti spontanei dell'imprenditorialità turistica, affidati al marketing operativo, puntando sulla progettualità strategica - e quindi sulla ricerca - da cui far discendere decisioni politiche e "good practices" (i progetti pilota per esempio). Le buone pratiche di gestione turistica di un territorio non potranno allora essere solo un fatto tecnico, ma reali occasioni di crescita su cui costruire una cultura diffusa dell'offerta che consenta di innescare il cambiamento all'interno di una strategia condivisa di sviluppo e di valorizzazione.

\section{Bibliografia}

F. Casarin, Il marketing dei prodotti turistici. Specificità e varietà, Torino, Giappichelli, 1996.

G. De Napoli, Tuttoturismo, "Urbanistica Informazioni”, 2005, 204, pp. 14-15.

C. De Seta, Bella Italia. Patrimonio e paesaggio tra mali e rimedi, Milano, Electa, 2008.

C. De Seta, L'Italia nello specchio del Grand Tour, in Storia d'Italia, Annali, Torino, Einaudi, 1982, pp. 127-263.

C. Ferrata, La fabbricazione del paesaggio dei laghi: giardini, panorami e cittadine per turisti tra Ceresio, Lario e Verbano, Bellinzona, Casagrande, 2008.

G. Fossa, La riqualificazione dei contesti dei nodi infrastrutturali. Un atlante per Milano, Milano, Skira, 2006.

M. Francini, A. Palermo, La pluralità del paesaggio nel progetto del patrimonio territoriale, in Atti della XV Conferenza SIU, Lurbanistica che cambia. Rischi e valori, Pescara, 2012.

Planum. The Journal of Urbanism, 2012, 25, http://www.planum.bedita.net/ siu/xv-conferenza-nazionale-siu-atelier-7-bis 
G. Imbesi, Il sapore, dolce, della ricerca, in N.G. Leone (a cura di), ITATOUR Visioni territoriali e nuove mobilità: Progetti integrati per il turismo nella città e nell'ambiente, Milano, Angeli, 2012, pp. 11-23.

R. Koolhaas, The generic city, in O.M.A., R. Koolhaas, B. Mau, $S, M, L, X L$, New York, The Monacelli Press, 1995, p. 1248.

E.J. Leed, La mente del viaggiatore, Dall'odissea al turismo globale, Bologna, Il Mulino, 1991.

N.G. Leone, Le ragioni del territorio e del turismo, in N.G. Leone (a cura di), ITATOUR accessibilità diffusa, spazi del tempo libero e territori del turismo nella punta occidentale della Sicilia, Milano, Angeli, 2013, pp.15-21.

N.G. Leone, Dal paesaggio alla gestione, in N.G. Leone (a cura di), ITATOUR Visioni territoriali e nuove mobilità: Progetti integrati per il turismo nella città e nell'ambiente, Milano, Angeli, 2012, pp. 23-36.

A. Marin, Turismo e urbanistica: strategie, strumenti e progetti, in "Urbanistica Informazioni”, 2005, 204, pp. 9-24.

D. Pandakovic, A. Dal Sasso, Saper vedere il paesaggio, Milano, Città Studi, 2009.

E. Petroncelli, Stanzialità, turismo, territorio tra locale e globale, in N.G. Leone (a cura di), ITATOUR Visioni territoriali e nuove mobilità: Progetti integrati per il turismo nella città e nell'ambiente, Milano, Angeli, 2012, pp. 167-176.

L. Urbani, Introduzione, in D. Gulotta, F. Naselli, F. Trapani (a cura di), Motris. Microcentralità relazionali nel Mediterraneo. Mappatura dell'offerta di turismo relazionale integrato in Sicilia, Palermo, Gulotta, 2004, pp. 17-22. 


\section{Un nuovo modo di pianificare il processo di sviluppo turistico}

Francesca Spagnuolo

Premessa. -Nella pianificazione turistica odierna si impongono due tipi di esigenze: l'esigenza di uno studio olistico e comprensivo dei processi turistici e l'esigenza di una sua programmazione e organizzazione a partire dalle trasformazioni sociali, politiche, economiche e culturali che si verificano nel contesto socioeconomico e territoriale in cui si sviluppa.

Si rinviene, nei contesti scientifici e nelle prassi di definizione delle politiche di sviluppo, la necessità di ricercare un modello di sviluppo turistico in grado di valorizzare le caratteristiche ele diversità dei contesti territoriali. Con ciò si sancisce l'importanza della scala locale come unità di analisi, interpretazione e progettazione.

Nonostante ciò, la pianificazione del turismo ha vissuto stagioni in cui non sempre la scala locale è stato il riferimento principale su cui predisporre la progettazione dello sviluppo turistico.

Diventa, pertanto, necessario comprendere come i modelli di sviluppo si siano evoluti nel corso del tempo ed in che modo questi hanno influenzato le forme ed i processi della pianificazione, in generale, e della pianificazione turistica, in particolare. 
Il ruolo che è stato attribuito alla pianificazione all'interno dei processi di sviluppo ricalca, nelle forme e nei contenuti, le evoluzioni che hanno caratterizzato i modelli di sviluppo. La pianificazione mutua, pertanto, la sua forma, le sue funzioni e le sue finalità a seconda del modello e della concezione di sviluppo di riferimento.

La pianificazione laddove è stata associata a modelli di sviluppo imposti e facenti riferimento ad un approccio funzionale dello sviluppo, ha visto attribuirsi accezioni non sempre positive, interpretata spesso come la negazione della democrazia e delle iniziative locali, nonché della partecipazione della cittadinanza. Il difetto principale a cui tende questo modello è quello di considerare le persone come l'oggetto dell'intervento piuttosto che il soggetto del potere formatosi nel processo di pianificazione.

Concetti come sviluppo endogeno, contestualizzato e sostenibile, hanno portato da un lato ad una rivalutazione del ruolo e dell'importanza della pianificazione nei processi di sviluppo, dall'altro lato alla definizione di alcune caratteristiche formali e processuali finalizzate al conseguimento dei principi e dei valori concettualizzati nel modello di sviluppo a cui si fa riferimento.

\section{L'affermarsi della scala locale come modello di sviluppo. - Il} percorso che ha portato ad inquadrare la pianificazione entro il paradigma dello sviluppo locale, può essere spiegato da un lato come un processo evolutivo dei modelli di sviluppo regionale e, dall'altro lato, come risposta alle evidenti esigenze di sostenibilità.

Il dibattito che porta alla definizione di un modello di sviluppo in cui acquistano rilevanza le risorse ed i soggetti locali si sviluppa a partire dagli anni Sessanta. Il contributo a questo dibattito proviene, tanto a livello nazionale quanto a livello internazionale, da un lato dall'evidenza esplicita di alcuni effetti negativi sul piano ambientale, sociale ed economico prodotti dai modelli di sviluppo dominanti, dall'altro lato dall'attenzione posta, soprattutto dagli studi di geografia regionale, su alcuni processi auto-organizzati che 
si verificavano in relazione al contesto di riferimento (i.e. distretti industriali). La definizione del modello di sviluppo locale passerà, pertanto, sia attraverso la "questione ambientale" e l'affermazione del concetto di sostenibilità nei processi di sviluppo (Conti, 1996), sia attraverso lo studio della forte interrelazione esistente tra alcune componenti dello sviluppo e i contesti territoriali (Dematteis, 1994), entrambi mossi dall'esigenza di riconoscere ad altre componenti, oltre a quella economica, il ruolo di determinante dei processi di sviluppo locale, considerando variabili socio-culturali, ambientali ed istituzionali.

Input provenienti dalla questione ambientale. - La dimensione ambientale inizia a ritagliarsi uno spazio all'interno dell'arena politica diventando una delle priorità strategiche dei governi nazionali anche se considerata, almeno fino agli anni ' 80 , sia in fase di analisi che di scelta decisionale, come una componente distinta dalla dimensione economica. A partire dagli anni '80 gli approcci ecologici - anche quelli più conservativi - iniziarono ad aprirsi alla considerazione di altre componenti dello sviluppo e la programmazione economica iniziò a non essere più sconnessa dalle dinamiche sociali, ambientali e culturali. Lattenzione prende gradualmente le distanze dalla mera conservazione delle risorse; gli approcci ecologici iniziarono, pertanto, a prendere in considerazione altri percorsi alternativi a quelli riconducibili alla sostenibilità forte, ovvero ad una sostenibilità che non ammette la sostituibilità delle risorse del capitale naturale con il capitale economico e sociale (Meadows, Randers, 1972). In questo senso il concetto di sostenibilità subisce un'estensione; da semplice tutela dell'ambiente naturale e dell'ecosistema si applica anche alle dinamiche di crescita economica e di sviluppo sociale e culturale. Fino agli anni Novanta la sostenibilità si interpretava nella pianificazione come "la pratica del vincolo, della protezione o al massimo di una cauta valorizzazione" (Calandra, 2002, pp. 113115). A partire dagli anni Novanta si inizia a fornire anche dal punto 
di vista metodologico un orientamento al progetto prendendo in considerazione "la gestione, il recupero, lo sviluppo di intere aree e territori” (ibidem).

Secondo questa prospettiva la sostenibilità si lega alla scala locale come unità ideale di progettazione di strategie e politiche di sviluppo maggiormente compatibili con i contesti territoriali.

Input provenienti dall'analisi delle dinamiche di sviluppo regionale. - Il contributo degli studi di geografia regionale all'affermazione della scala locale consiste nell'aver riconosciuto l'importanza di alcuni fattori, non solo materiali ma soprattutto processuali ed organizzativi, fortemente localizzati; in particolare attraverso lo studio delle differenze del sistema produttivo italiano che si andavano affermando a partire dagli anni '70. L'emergere di nuove forme di produzione ed il declino del sistema fordista lasciarono spazio a nuove interpretazioni del concetto di sviluppo, che si caratterizzavano per la partecipazione di tre dimensioni interdipendenti (Storper, Scott, 1992), ovvero:

- il contesto istituzionale;

- le dinamiche evolutive;

- il radicamento territoriale e la specificità territoriale.

Questo processo porto all'affermazione di una concezione dello sviluppo come processo localizzato e fondato su meccanismi di territorialità (Coppola, 1997), in cui i rapporti sociali storicamente radicati, nonchè la presenza di un sistema di valori e di una cultura locale tipica generano organizzazioni territoriali peculiari che favoriscono la diffusione e la riproduzione di conoscenza. Dal punto di vista dello sviluppo locale, queste considerazioni risultarono funzionali al mantenimento di una certa competitività all'interno dei contesti globalizzanti e globalizzati. Oggi, proprio perché la competizione si gioca su flessibilità, qualità e innovazione, 
assumono rilevanza, a sostegno delle differenze territoriali, delle combinazioni vincenti tra: i cosiddetti "fixed asset" (Amin, 2000), esplicativi di certi vantaggi comparati, gli elementi relazionali ed i fattori ambientali immateriali appartenenti alla cultura locale. Ci si riferisce a risorse specifiche irriproducibili, in quanto insieme di condizioni che costituiscono il prodotto storico dell'azione congiunta dei soggetti localizzati (Governa, 1997; Dematteis, Governa, 2005). Per attuare una contestualizzazione dei modelli di sviluppo non è sufficiente la dotazione di risorse, bensì devono essere presenti degli elementi di processo che guidano l'azione; pertanto vengono introdotti concetti quali: apprendimento collettivo, coesione socioculturale e consapevolezza.

Modelli di sviluppo e pianificazione. - Il testo di John Friedmann e Clyde Weaver (1979) dà l'avvio, da un punto di vista concettuale, all'analisi delle basi territoriali dello sviluppo. Friedmann contribuisce a spostare il pensiero da un approccio funzionale allo sviluppo ad uno territoriale in cui promuovere i meccanismi bottom-up e l'empowerment locale (Friedmann, 1992). Sebbene l'autore (Friedmann, 1992, p. 7) tratti la dimensione territoriale nell'ottica delle esigenze di allocazione delle risorse, riscopre nel suo modello di sviluppo la territorialità e lo spazio di vita come elementi imprescindibili per la definizione delle politiche e dei processi decisionali. Lo sviluppo dal basso necessita di essere strettamente correlato alle specifiche condizioni socio-culturali, storiche ed istituzionali (Potter, Binns, Elliot, Smith, 2008, p. 117). Questo comporta, pertanto, un focus sui progetti a scala locale (Brohmam, 1996).

E' alla fine degli anni Settanta che Friedmann e Weaver (1979) proposero la distinzione di due accezioni contrapposte del concetto di sviluppo regionale (Conti, 1996, p. 188): 
- funzionale, relativo cioè alle logiche di programmazione della distribuzione delle attività economiche su uno spazio "razionalmente strutturato" in un sistema di centri e di reticoli. Sul piano operativo, la definizione di una politica regionale assumerà in questo caso gli strumenti concettuali della scienza spaziale di matrice positivistica (come il concetto di polarizzazione, il modello gravitazionale etc.);

- territoriale, nel qual caso, in contrasto con l'approccio precedente, si privilegia una strategia di attivazione dei fattori di sviluppo endogeni e l'attenzione viene posta sulle forme di organizzazione economica e sociale specifiche delle singole realtà regionali. La "riscoperta della territorialità" intesa come insieme riproducibile di rapporti sociali ed economici, si accompagna all'affermazione della necessità di una diretta partecipazione dei soggetti locali alle decisioni economiche e politiche. Secondo Friedmann (1992) una condizione necessaria per determinare la presenza o l'assenza di "sviluppo", è una democrazia "inclusiva" correlata ad un discorso di "accountability" e di accesso all'informazione. Friedmann (1992) insiste sul concetto di territorialità per varie ragioni:

- il territorio coincide con lo spazio di vita;

- la territorialità esiste a tutte le scale geografiche e simultaneamente si è cittadini di più di una comunità e a differenti scale geografiche;

- la territorialità è un processo che connette passato e presente;

- la territorialità protegge e sviluppa un'etica di attenzioni ed interessi per i cittadini e l'ambiente. 
Secondo la terminologia introdotta da Stohr e Taylor (1981), l'accezione funzionale ha determinato una sorta di "sviluppo dall'alto" (top-down) ed è stata alla base delle politiche regionali e della programmazione economica nei primi tre decenni del dopoguerra. In questo periodo la pianificazione era di tipo spaziale (Chadwick, 1971), incentrata sull'analisi e la modellizzazione di funzioni in uno spazio "razionalmente strutturato"; la definizione delle politiche avveniva ad opera di organismi tecnici totalmente esterni alle comunità cui i programmi di sviluppo erano destinati. Questi modelli di sviluppo esogeno pertanto, non solo si caratterizzano per l'applicazione di strumenti concettuali della scienza spaziale di matrice positivistica (come il concetto di polarizzazione, il modello gravitazionale etc.), ma anche per la replicabilità delle forme indipendentemente dalle specificità e dalle differenze presenti in ciascun contesto. I risultati prodotti da questo tipo di programmazione possono essere sintetizzati in alcune parole chiave: assenza di un modello di analisi dettato da una visione olistica del territorio; assenza di una coerenza d'insieme nei percorsi di sviluppo; proliferazione di iniziative spontanee ed, il più delle volte, generate al di fuori delle regole stabilite all'interno della pianificazione ordinaria; sfruttamento con obiettivi a breve termine delle risorse materiali.

Il fallimento dei modelli di matrice funzionalistica ha introdotto nuove categorie e assunti concettuali; si è passati da un'organizzazione spaziale a un'organizzazione territoriale; da sviluppo esogeno a sviluppo endogeno; da spazio come contenuto passivo a territorio come soggetto attivo; da decontestualizzazione dei processi di sviluppo a compatibilità territoriale dei modelli.

Le riflessioni iniziano a dirigersi verso i processi di pianificazione community-based, si affermarono visioni "bottom-up" in contrasto con le visioni "top-down", accentuando esplicitamente la natura interattiva del "doing planning work" (Healey, 1997). 
In questo senso viene attribuito un ruolo rilevante al processo attraverso il quale vengono raggiunti obiettivi di sviluppo.

Non meno importante è l'analisi dei livelli di partenza, poiché il processo di partecipazione deve comunque svilupparsi a partire dall'identificazione delle condizioni necessarie per il raggiungimento di uno sviluppo sostenibile.

Come affermano Davoudi e Strange (2009), la "reflexive planning" si diffonde con il passaggio interpretativo da un concetto di spazialità assoluta (space) ad uno di spazialità socialmente costruita (place). Nella pianificazione tale passaggio viene sancito con lo spostamento da una dominanza del positivismo e dello strutturalismo all'affermazione di un post- strutturalismo. La "dialettica socio-spaziale", già presente nello strutturalismo, diventa una caratteristica centrale dell'approccio post-strutturalista.

La scala influenza il metodo di analisi dei contesti. - Questa evoluzione concettuale dei modelli di sviluppo ha determinato delle implicazioni nel metodo di analisi dei contesti territoriali portando alla considerazione di molteplici componenti in un'ottica sistemica.

Se da un punto di vista concettuale si è assistito ad un'evoluzione verso forme di sviluppo endogeno, dal punto di vista delle chiavi di lettura e della definizione strategica delle politiche di sviluppo si è affermata l'ottica sistemica ed integrata.

L'evoluzione delle teorie sistemiche contribuisce a validare l'ipotesi che il sistema locale non è più uno scenario dove si svolge l'azione, la "proiezione territoriale" dell'impresa, come suggeriva il modello capitalistico, ma è invece l'azione stessa (Coppola, 1997; Clementi, Dematteis, Palermo, 1996). Nell'ambito dell'apparato sistemico si è verificata un'evoluzione verso accezioni complesse, passando per la concettualizzazione dei sistemi aperti passivi, superando la contrapposizione tra sistemi aperti e sistemi chiusi, fino ad arrivare alla definizione dei sistemi aperti attivi, ovvero 
sistemi che hanno la capacità di far interagire, per processi cumulativi, i fattori locali sia con i fattori esterni che con le dinamiche di mercato, acquisendo pertanto, mediante processi di auto-organizzazione, un ruolo di protagonismo nei processi di sviluppo. E' il concetto di autopoiesi, introdotto già negli anni '70 da Maturana e Varela (1987), a garantire la contestualizzazione dei modelli di sviluppo. Questo indica la capacità del sistema di progettare e di riprodurre se stesso nel rapporto con l'ambiente esterno, mantenendo una coerenza interna grazie alla sua capacità di essere sistema attivo e non dipendente. E' lo stato di coerenza interna a rendere il sistema unico e specifico nel suo genere e a differenziarlo dagli altri. I sistemi autopoietici si caratterizzano per essere composti da:

- potenziale endogeno;

- specificità;

- strategie Selettive.

Inoltre, la categoria concettuale di territorio sta dunque a rappresentare un ispessimento e una sedimentazione locale di relazioni sociali, specifiche e non trasferibili. Anche Friedmann (1992) cita Karl Polanyi (1977), secondo il quale le relazioni economiche sono profondamente radicate nella matrice delle relazioni sociali e culturali. Infatti:

- ogni comunità organizzata territorialmente possiede proprie risorse che costituiscono un potenziale endogeno per l'attivazione di forme di sviluppo integrato;

- l'insieme di questi fattori definisce l'identità regionale, qualitativamente irripetibile, in ragione delle specifiche modalità di interazione fra i fattori stessi, espressione a sua volta della partecipazione attiva - politica e decisionale delle comunità interessate. Quest'ultima è necessaria non 
solo per la valorizzazione delle potenzialità endogene, ma per il controllo delle forme di influenza esterna e la prevenzione degli effetti negativi sull'economia e l'organizzazione comunitaria della regione;

- le strategie di sviluppo auto centrato basate sulla massima valorizzazione dei potenziali endogeni, dovranno essere selettive, cioè incentrate su alcune variabili chiave: in particolare, saranno privilegiati i settori orientati al soddisfacimento dei bisogni fondamentali della popolazione (nei paesi sottosviluppati, anzitutto), quelli caratterizzati da un'elevata intensità di lavoro e/o dalla prevalenza di unità produttive di piccola dimensione, lo sviluppo di una tecnologia appropriata alle condizioni storico-culturali della regione;

- questi concetti saranno applicati alle diverse scale geografiche, cioè a ogni livello territoriale in cui si ritrovano le condizioni naturali, umane e istituzionali potenzialmente capaci di attivare un processo di sviluppo relativamente autonomo.

L'applicazione dell'approccio sistemico ai modelli di sviluppo auto centrato permette di capire e comprendere il funzionamento di questi modelli. Il sistema è caratterizzato da una struttura - insieme di elementi e relazioni tra elementi caratterizzate da retroazione - e dall'organizzazione - insieme di processi legati tra loro che attribuiscono al sistema una certa coerenza. E' l'organizzazione che informa sul funzionamento del sistema ed è la chiave per uno sviluppo turistico "territorializzato", "integrato" con gli altri strumenti di programmazione e dotato di "convergenza strategica". Il concetto di "governance" contrapposto a quello di "government" ben esemplifica la capacità di organizzazione del sistema e di orientamento alla strategia. Per government si intende, infatti, un modello di gestione del territorio fortemente gerarchico 
e improntato sull'autorità del pubblico, mentre per governance si intende un modello di governo che privilegia l'interazione tra pubblico e privato, nonché la partecipazione alle scelte decisionali da parte degli attori.

Ladozione di un approccio territorialista per lo studio delle dinamiche del turismo presuppone un "comprehensive approach" per capire le interrelazioni ed i meccanismi di interscambio all'interno di una destinazione. Come affermano Butler, Pearce (1995) e Pike (2004), facendo riferimento al concetto di destinazione, il turismo è un multifaceted e multiattributed phenomenon. Il turismo, pertanto, proprio perché è un fenomeno multivariato, si insedia in aspetti socio-economici e culturali dell'area di destinazione non sempre ad esso direttamente connessi, accrescendo la complessità delle analisi delle dinamiche del turismo e giustificando alla base delle stesse l'adozione di un approccio territorialista.

Lapproccio territorialista viene utilizzato in fase di analisi con l'obiettivo di presentare il "sistema di opportunità" che il territorio offre al turismo. Lobiettivo è cogliere il "progetto di territorio", ovvero quell'insieme delle trasformazioni sociali, economiche e territoriali che gli attori manifestano nelle loro azioni, al fine di comprendere le opportunità per lo sviluppo turistico.

Quest'importanza attribuita agli attori locali rientra in una concezione del territorio "come costruzione sociale che fonda l'identità locale in funzione dell'azione collettiva dei soggetti (il territorio - progetto)" (Bourdin, 1994).

L'impostazione dell'analisi sull'approccio territorialista è finalizzata alla definizione di uno sviluppo turistico maggiormente compatibile con le caratteristiche territoriali.

L'importanza del processo e degli attori locali. - Friedmann (1992, p. 40) nel descrivere il lato qualitativo dello sviluppo verso cui tendere, quello che lui chiama "better", impone l'esistenza di un 
processo decisionale il quale è accettato e legittimato dai partecipanti e dagli altri individui interessati e/o connessi al processo.

Negli studi sul "social learning" nei processi di pianificazione (Bennet, Howlett, 1992), quest'ultima viene interpretata come una serie di attività e processi ricorsivi e potenzialmente riflessivi, in cui l'adattamento sociale e cognitivo rappresenta la chiave del successo delle pratiche di pianificazione.

Il dibattito sul processo e sulle forme assunte dalla pianificazione si articola attorno alla scelta dell'approccio da adottare per la definizione dei processi decisionali.

I principali vantaggi di un approccio partecipativo sono stati individuati da Martin Purvis e Alan Grainger (2004, p. 79) in relazione ai seguenti punti:

- assicurare un migliore flusso bidirezionale di informazioni tra il livello nazionale e sub-nazionale;

- migliorare la formulazione delle politiche bilanciando la visione del governo nazionale e il ruolo di coordinamento del pubblico con la creatività della popolazione locale e la conoscenza delle condizioni specifiche della zona interessata;

- essere compatibile con l'ambiente partendo dal presupposto che tutti sono propensi a conservare il proprio ambiente;

- migliorare le capacità di attuazione dei progetti in quanto i soggetti locali saranno più propensi alla realizzazione di qualcosa alla quale hanno contribuito.

In questo senso $\mathrm{i}$ soggetti locali si comportano come "planners" anche se aiutati e supportati dalle competenze esterne durante il processo di pianificazione turistica. Questo aspetto è strettamente connesso al livello di partenza di "dotazione 
cognitiva" di cui il sistema è dotato e su cui l'analisi ci informa. Alcune riflessioni sul tema (Clementi, Dematteis, Palermo, 1996, p. 188) sottolineano, infatti, l'impegno a sostenere "la necessità del coinvolgimento di soggetti locali e componenti endogene dello sviluppo nei processi di pianificazione, el'importanza del contributo di comitati e istituzioni non governative al fianco dei tecnici e della pubblica amministrazione".

La centralità dei soggetti locali lascia emergere l'importanza della scala locale (Purvis, Grainger, 2004, p. 39) come un'arena importante per il decision-making e l'azione. Del resto però qualsiasi ideale di progresso basato sul riconoscimento di responsabilità condivise per lo sviluppo sostenibile sembra vulnerabile ai desideri di particolari luoghi e soggetti nell'inseguire il proprio sviluppo libero da considerazioni e contrasti esterni. Alcune misure di coordinamento sono indubbiamente necessarie per trovare un equilibrio tra libertà e responsabilità individuale (Purvis, Grainger, 2004, p. 47). E' necessaria, pertanto, una comprensione olistica ed integrata dei caratteri e delle circostanze dei territori e del loro livello di funzionamento con gli altri contesti.

Healey propone, dunque, un modello di "collaborative planning" che si basa su due tipi di approcci:

- institutionalist approach, poiché la formazione delle politiche pubbliche non è vista più solo come un prodotto tecnico e si concentra, invece, sui meccanismi complessi di valutazione;

- communicative approach, grazie all'interpretazione fenomenologica della relazione tra conoscenza e azione, al fine di disegnare il sistema di governance, focalizzando l'attenzione sulla collaborazione. Questa idea si basa sull'assunzione che conoscenza e valore sono attivamente costituiti attraverso processi sociali interattivi. 
Healey riconosce il grande potenziale offerto dalla pratica discorsiva impostata su interessi condivisi, nel generare percorsi di apprendimento costruendo un bagaglio di comprensione collettiva, una specie di capitale intellettuale e sociale. Questi elementi processuali incrementano la capacità istituzionale a collaborare e a coordinare, sviluppando una maggiore comprensione e consapevolezza dei conflitti che insistono nel contesto locale.

Il ruolo della pianificazione turistica entro lo schema del "competitive and sustainable development". - La pianificazione del turismo è qualcosa di complesso; secondo Hall (1995) la pianificazione del turismo differisce a seconda dell'obiettivo strategico (es. infrastrutturazione e marketing), tipologie dei soggetti coinvolti (pubblico e privato), scala geografica (nazionale, regionale e locale) e tempistica (cicli ed implementazione).

La forma ed i processi di pianificazione si propongono di rispondere ad una serie di quesiti fondamentali:

- tipologia di turismo più appropriato per il contesto territoriale;

- scala di sviluppo;

- tassi di crescita del turismo.

La bibliografia internazionale di revisione degli approcci utilizzati per la pianificazione turistica, propone una classificazione di questi in quattro categorie (Williams, 2009):

- boosterism;

- industry oriented;

- physical-spatial;

- community-oriented. 
Boosterism è l'approccio dominante in molte destinazioni turistiche (Hall, 2000). Solitamente questo approccio si basa sullo sfruttamento delle risorse naturali e culturali al fine di massimizzare il ritorno economico. La partecipazione locale non è la caratteristica di questo tipo di pianificazione, nella quale invece le decisioni vengono prese dal pubblico o da alcuni esperti. Anche gli impatti costituiscono un elemento residuale poiché l'attenzione si concentra sullo sviluppo economico.

Industry-oriented è una forma "regolata" dell'approccio precedente. Il focus è posto sul raggiungimento di un uso efficiente e sostenibile delle risorse al fine di incrementare lo sviluppo regionale e l'occupazione. Le attività come il marketing e la promozione diventano fondamentali, mentre gli interessi ambientali e socio-culturali, così come la redistribuzione degli effetti positivi prodotti dal turismo, costituiscono delle priorità minori (Burns, 1999).

Physical-spatial approaches si basa sulle tradizionali forme di pianificazione urbanistica e focalizza l'attenzione sull'infrastrutturazione dello spazio e sull'uso del suolo. Questo approccio è fortemente rappresentato in molti testi di pianificazione turistica (Inskeep, 1991) ed è maggiormente attento alla progettazione fisica dello spazio e allo zooning delle attività (ovvero ripartizione spaziale delle strutture e delle funzioni). Come risposta alle indicazioni sulla sostenibilità anche questo approccio è diventato più sensibile ad una maggiore gestione degli impatti ambientali del turismo, sebbene risulti ancora quasi assente l'integrazione con gli interessi socio-culturali.

Community-oriented approaches si è diffuso, invece, in tempi recenti anche se il suo riferimento scientifico è imputabile a Murphy (1985). Questo approccio guarda alla partecipazione locale come condizione essenziale per assicurare uno sviluppo sostenibile del turismo e l'effettiva gestione degli impatti.

La pianificazione del turismo è stata considerata per molto tempo come: 
- land use planning - pianificazione relativa all'uso del suolo;

- $\quad$ site specific planning for recreation - pianificazione di specifiche risorse per il tempo libero (Hall, Page, 2006).

Queste due tipologie di pianificazione sono guidate da principi spaziali i quali vengono considerati, nella maggior parte dei casi, degli approcci di analisi riduttivi, in quanto danno vita a forme di pianificazione dotate di una forte rigidità e di un ruolo normativo, che non sono in grado di offrire forme flessibili o di orientamento al mercato. La "land use planning" rientra in un discorso di tipo urbanistico, mentre la "Site specific planning" si connette ad un discorso di pianificazione sovraordinata di tutela di aree d'interesse naturalistico.

Di contro, le tipologie di pianificazione strutturate su studi olistici ed onnicomprensivi dell'offerta e su spirito di adattamento alle trasformazioni della domanda, sono, invece, considerate importanti per una serie di ragioni (Williams, 2009, p.161). Innanzitutto forniscono, ad un livello prettamente fisico e spaziale, la capacità di prevedere un'adeguata infrastrutturazione dello spazio, in termini di accessibilità ed accoglienza, a tutte le scale geografiche. Ad un livello socio-economico si può predisporre una maggiore sostenibilità nei meccanismi di distribuzione e redistribuzione degli investimenti connessi al turismo e dei benefici da esso derivanti. Una pianificazione di questo tipo è, infine, importante poiché anticipa gli interessi della domanda, rispecchiando, pertanto, l'orientamento al mercato e l'apertura all'esterno del sistema territoriale in cui si sviluppa l'offerta turistica.

Attualmente, il ruolo della pianificazione turistica acquista importanza per effetto di due pressioni che coinvolgono anche il turismo (Goeldner, Ritchie, 2008): la crescente competizione e il mantenimento dell'integrità ecologica. Si parla, pertanto, di "competitive and sustainable development" e il turismo è spesso 
diventato uno degli elementi per accrescere la competitività del territorio e per perseguire pratiche di sviluppo sostenibile, non solo ecologico. Il fine ultimo della pianificazione turistica dovrebbe essere, pertanto, duplice, ovvero da un lato ridurre gli impatti, dall'altro lato assicurare la qualità dell'esperienza turistica.

Molti autori sostengono che il ruolo della pianificazione è nell'assicurare uno schema ordinato e appropriato dello sviluppo e nel risolvere ulteriori conflitti che si generano a partire dall'attivazione di processi di sviluppo (Gunn, 1994; Inskeep, 1991). Si individua, dunque, nella pianificazione il processo attraverso il quale raggiungere obiettivi di sviluppo sostenibile (Williams, 2009). Questo obiettivo generale viene raggiunto attraverso alcuni risultati che la pianificazione si prefigge di perseguire, tra cui:

- l'integrazione del turismo con gli altri settori economici;

- il controllo e la gestione di alcuni processi dello sviluppo;

- la conservazione di risorse importanti o rare;

- la promozione e il marketing della destinazione;

- la creazione di relazioni "positive" tra i turisti e la comunità in generale.

Da questi risultati derivano le caratteristiche formali della pianificazione, ovvero: l'integrazione con gli altri settori, la previsione di strumenti di monitoraggio e di valutazione, la previsione di meccanismi di gestione delle risorse, lo sviluppo di una cultura dell'accoglienza e dello spirito di ospitalità della destinazione.

Anche Long e Nuckolls (1994) individuano alcune condizioni della pianificazione essenziali per uno sviluppo turistico sostenibile, riassumibili nei seguenti punti: 
- pro attività e dinamismo, ovvero un allontanamento della pianificazione dallo sviluppo di un'offerta turistica statica;

- orientamento alla comunità, come base concettuale ed operativa che ispira principi e strumenti della pianificazione;

- integrazione con le più ampie strategie di sviluppo economico e regionale.

"Una pianificazione pro-attiva, guidata dalla comunità locale, che va oltre lo sviluppo e la promozione di un'offerta turistica statica, è essenziale per il successo di uno sviluppo turistico sostenibile. Inoltre, la pianificazione turistica deve essere integrata nelle più ampie strategie di sviluppo e gestione delle dinamiche socio-territoriali a livello locale e regionale. I contesti che falliscono nell'organizzare le risorse e nel pianificare strategicamente il turismo si confrontano, con più probabilità, con uno sviluppo disordinato nel breve termine che sfocia, nel lungo termine, in conseguenze negative sotto l'aspetto economico, sociale ed ambientale" (Long, Nuckolls, 1994, p. 19).

L'importanza del processo nella pianificazione turistica. L'adozione di un approccio di pianificazione che si basa sui contesti territoriali provoca altre due implicazioni ovvero:

- l'importanza del processo di costruzione dell'agire territoriale che attribuisce caratteristiche "processuali" alla pianificazione;

- la scelta di alcune tecniche e metodi nei processi di pianificazione in grado di garantire la partecipazione;

- la partecipazione è funzionale al raggiungimento di due obiettivi: 
- ridurre il gap di conoscenza presente in alcuni attori che non consente di agire in modo responsabile e sostenibile, e di rendere operative le decisioni prese (knowledge gap);

- favorire meccanismi di condivisione delle best practices innescando la produzione di nuova conoscenza (knowledge sharing).

Alcuni studi di pianificazione del turismo (Timothy, 2001) concordano sul fatto che lo sviluppo del turismo sostenibile può realizzarsi meglio attraverso il coinvolgimento della comunità locale nel processo decisionale e la collaborazione tra gli stakeholders e le varie parti interessate. Il turismo può essere più sostenibile, e dunque di successo, se alla comunità locale, alle imprese locali e agli altri stakeholder viene data la possibilità di partecipare allo sviluppo turistico (Bramwell, Lane, 2000; Gunn, 1994; Inskeep, 1991; Murphy, 1985). Le basi della partecipazione nello sviluppo turistico possono essere viste da almeno due prospettive: gli attori locali devono essere investiti di potere per avere la capacità di determinare i loro obiettivi, bisogni e desideri in riferimento ai percorsi di sviluppo; devono, inoltre, avere l'opportunità di beneficiare, in termini economici e sociali, del turismo (Brohman, 1996;_Friedmann, 1992). Ai processi decisionali caratterizzati da una partecipazione e da una condivisione delle decisioni viene, pertanto, associata una "sustainability action", la quale deriva da due ordini di motivi, ovvero l'acquisizione immediata di responsabilità (ex-ante) da parte degli attori, nonché la possibilità di governare il processo fin dalla fase iniziale.

La partecipazione nei processi di pianificazione turistica acquista rilevanza per due motivazioni: 
- in quanto si garantisce una attitudine all'accoglienza ed $i$ residenti sono parti essenziali dell'atmosfera dell'ospitalità (Goeldner, Ritchie, 2008);

- in quanto gli attori locali con la propria azione rendono operativa la progettualità e la trasformano in "prodotto" (Buhalis, 2002).

La community based planning è la tipologia di pianificazione che più rispecchia l'approccio partecipativo. Sebbene il dibattito relativo alla partecipazione e al community based planning si appoggi ad alcuni modelli proposti negli anni '80 (Blank, 1989; Murphy, 1985), la riflessione continua anche in tempi recenti (Dredge, Jenkins, 2007; Singh, Timothy, Dowling, 2003). Mitchell, Reid (2001) - come ricorda Williams (2009, p. 175) - hanno elaborato uno schema concettuale per esaminare come le prospettive di una comunità si formano e vengono integrate nel processo di pianificazione turistica. Le differenze che si riscontrano nei parametri chiave di consapevolezza, coesione e potere tenderanno a regolare la capacità di una comunità di prendere parte al processo di pianificazione. Questa caratteristica specifica di ciascun contesto contribuisce a comprendere perché il successo di un approccio di pianificazione basato sulla partecipazione differisce da luogo a luogo. Secondo questo modello la consapevolezza rappresenta un fattore critico di successo per l'esercizio di quella capacità di influenzare il processo decisionale.

Gli enti istituzionali presenti a livello locale svolgono un ruolo di coordinamento importante soprattutto in quelle condizioni in cui c'è molta frammentazione degli attori - un ruolo da metamanager dello sviluppo, cosi come definito nell'ottica delle discipline di management delle istituzioni (Normann, 1977). In questo caso l'istituzione funge da collante dei meccanismi di territorialità presenti in un contesto, ma non sempre operanti in un'ottica dialogica e convergente. Soprattutto può costituire un 
impulso per quegli attori che Turco (2010, p. 92) definisce attori paradigmatici - ovvero che non posseggono un programma o la capacità di realizzarlo. In riferimento allo sviluppo del turismo, Hollinshead (1990) argomenta che gli enti pubblici possono agire come regolatori, players, o partners esercitando influenza e controllo attraverso le funzioni di regolamentazione e di servizio.

Tra le tecniche utilizzate per favorire la partecipazione nella pianificazione turistica le più comuni, almeno in una prima fase, sono le interviste seguite, in una seconda fase, dall'organizzazione di "focus group". In particolar modo le interviste hanno a che fare con il consenso se si sostanziano in una semplice raccolta di informazioni su decisioni già prese; tale tecnica sarà in questo caso finalizzata al raggiungimento di administrative objectives (Marien, Pizam, 1997). Il metodo è diverso se invece le interviste, per cui è richiesta la partecipazione, si basano su un rapporto di co-produzione dei contenuti per l'interpretazione dell'esistente e la definizione di scenari strategici, a favore di un processo di accrescimento di conoscenza. Non essendo possibile coinvolgere la totalità dei residenti, soprattutto in contesti territoriali mediograndi, nell'ambito della pianificazione turistica si tende a procedere dapprima con il coinvolgimento degli attori principali. Il coinvolgimento dei residenti e dell'intera comunità locale si verifica, invece, in un secondo momento e spesso si presenta come una strategia all'interno della pianificazione, finalizzata a:

- sviluppare una cultura dell'accoglienza e dell'ospitalità;

- accrescere la conoscenza dei prodotti turistici offerti.

Nella letteratura internazionale sul community based planning si riconosce una importanza rilevante al processo di pianificazione, in grado di sviluppare una conoscenza collettiva ed una capacità auto organizzativa dei contesti tali da favorire il raggiungimento di obiettivi di sviluppo sostenibile (Moscardo, 2008). 
Le riflessioni che studiano i processi di costruzione della capacità auto organizzativa - o community capacity - si basano sul presupposto che vi è una mancanza di conoscenza collettiva - lack of knowledge - relativa alle tematiche riguardanti lo sviluppo turistico. $\mathrm{Si}$ ritiene, invece, che questa costituisca la base su cui impostare la capacità dei contesti di definire e gestire le opzioni di sviluppo turistico e, a sua volta, promuovere modelli di sviluppo endogeno ed auto centrato. La mancanza di conoscenza nel turismo riflette spesso la mancanza di conoscenza sullo sviluppo in generale e limita la possibilità di sviluppare, internamente ai territori, pratiche di pianificazione e di valutazione critica delle opzioni di sviluppo, inibendo la formazione di leadership locali, di meccanismi di coordinamento e di partecipazione degli stakeholders. La conoscenza è considerata, pertanto, una determinante per la costruzione di una capacità auto organizzativa in grado di:

- migliorare l'abilità di una valutazione ed un'interpretazione critica del turismo ed i suoi risultati;

- migliorare la partecipazione pubblica ai processi di sviluppo turistico e sviluppare momenti e strutture di dialogo - così come le partnership - con gli attori che operano in altri contesti (Walker, 2008). Questo inoltre consente di staccarsi da meccanismi di dominanza da contesti esterni (Moscardo, 2008).

Oltre alla conoscenza, un'altra determinante per la costruzione della capacità auto organizzativa dei contesti è il ruolo critico svolto dal capitale sociale. La conoscenza permette alla comunità di prendere attivamente parte alle decisioni sullo sviluppo turistico. Una mancanza di conoscenza produce una consapevolezza limitata riguardo ai benefici associati al turismo ed alle opportunità che questo può generare sul piano dello sviluppo locale (Hall, 2005). 
Alcuni autori (Moscardo, 2008; Walker, 2008) riflettono su un modello di costruzione della capacità auto organizzativa come fase preliminare a qualsiasi attività decisionale e di pianificazione turistica. Il processo proposto da Moscardo (2008) prevede: una fase iniziale di costruzione/miglioramento della conoscenza e della consapevolezza riguardo allo sviluppo turistico - in quanto determinanti del processo di costruzione della community capacity -; una fase intermedia di integrazione nelle più ampie politiche di sviluppo (McCool, Moisey, 2001) - in quanto il turismo è spesso considerato, analizzato e valutato in modo isolato dalle altre attività ; una fase di costruzione della community capacity che si realizza con la partecipazione attiva alla pianificazione turistica. Walker (2008) rileva, inoltre, che si verifica un processo ricorsivo - feedback loop - tra la prima e l'ultima fase, in cui il learning by doing e l'atteggiamento riflessivo contribuiscono ad un'attività continua di costruzione della conoscenza e della consapevolezza (Monypenny, 2008).

Il processo di pianificazione è, pertanto, visto come uno strumento in grado di generare nuova conoscenza. Questa viene studiata non solo - come già affrontato - in quanto determinante della costituzione di una capacità auto-organizzativa, ma anche come determinante dei processi di innovazione territoriale (Hall, Williams, 2008). In particolare gli autori rilevano una scarsa considerazione di questi fattori nelle analisi territoriali. Le osservazioni empiriche sul turismo si basano, infatti, su dati quantitativi relativi alla crescita delle attività, flussi turistici, occupazione, impatti economici, mentre molto spesso le fonti dell'innovazione turistica risiedono al di fuori del settore. L'innovazione turistica non è da ricercare solo in alcuni posti o solo in alcune imprese, piuttosto l'innovazione pervade tutti gli angoli del sistema turistico, dal piccolo albergo che crea il suo primo sito web, al ristorante che introduce nuovi piatti per attirare un mercato turistico emergente, ai turisti individuali che creano nuove modalità di turismo (ibidem, p. 3). 
L'innovazione è un fattore intrinsecamente territoriale e dipende dalla localizzazione di specifiche risorse e dalle connessioni relazionali entro e tra contesti diversi. Per tale motivo la scala locale e quella regionale sono i livelli ottimali per il suo sviluppo.

\section{Bibliografia}

A. Amin, The Economic base of contemporary city, in G. Bridge, S. Watson (eds), A companion to the city, Oxford, Blackwell, 2000, pp. 115-129.

C. Bennet, M. Howlett, The lessons of learning: reconciling theories of policy learning and policy change, "Policy Sciences", 1992, 3, pp. 275-294.

S. Berardi, Principi economici ed ecologici per la pianificazione di uno sviluppo turistico sostenibile, Milano, Angeli, 2007.

U. Blank, The Community Tourism Industry Imperative: The Necessity, The Opportunities, Its Potential, State College (PA), Venture Publishing, 1989.

A. Bourdin, Pourquoi la perspective invente-t-elle des territories?, "Espaces et Sociétés", 1994, 74-75, pp. 215-236.

B. Bramwell, B. Lane (eds), Tourism Collaboration and Partnerships: Politics, Practice and Sustainability, Clevedon, Channel View Publications, 2000.

J. Brohman, Popular development: rethinking the theory and practice of development, Oxford, Blackwell, 1996.

D. Buhalis, Information Technology and Tourism: Trends and Developments, "Tourism Studies of Catalonia", 2002, 10, pp. 21-26.

P. Burns, An Introduction to Tourism and Antrophology, London, Routledge, 1999.

P. Burns, Tourism Planning: A Third Way?, "Annals of tourism research", 2004, 1, pp. 24-43.

R. Butler, D. Pearce (ed), Change in Tourism, People, Places, Processes, London, Routledge, 1995.

L. Calandra, La cultura del progetto: il paesaggio come unità di pianificazione territoriale in Europa, in A. Turco (a cura di), Paesaggio: pratiche, linguaggi, mondi, Reggio Emilia, Diabasis, 2002, pp. 109-143.

M. Carta, Teorie della pianificazione. Questioni, paradigmi e progetto, Palermo, Palumbo, 2003.

M. Carta, Governare l'evoluzione. Principi, metodologie e progetti per una urbanistica in azione, Milano, Angeli, 2009.

S. Cerutti, La filiera programmatica del turismo regionale nel quadro strategicooperativo europeo e nazionale, in C. Emanuel, S. Cerutti, M. E. Rossi, Pro- 
gettare il cambiamento. Filiere programmatiche e iniziative di sviluppo turistico in Piemonte, Vercelli, Mercurio, 2011, pp. 75-98.

G.F. Chadwick, $A$ systems view of planning: towards a theory of the urban and the regional planning process, Oxford, Pergamon Press, 1971.

A. Clementi, G. Dematteis, P.C. Palermo (a cura di), Le forme del territorio italiano, voll. I e II, Roma-Bari, Laterza, 1996.

S. Conti, Geografia economica, Torino,Utet, 1996.

C. Cooper, J. Fletcher, A. Fyall, D. Gilbert, S. Wanhill, Tourism: principles and practice Harlow, Pearson Education, 2008.

P. Coppola (a cura di), Geografia politica delle regioni italiane, Torino, Einaudi, 1997.

S. Davoudi, I. Strange (eds), Conceptions of Space and Place in Strategic Spatial Planning, Londra, Routledge, 2009.

G. Dematteis, Possibilità e limiti dello sviluppo locale, "Sviluppo locale", 1994, 1, pp. 10-30.

G. Dematteis, F. Governa (a cura di), Territorialità, sviluppo locale, sostenibilità: il modello SLoT, Milano, Angeli, 2005.

R.K. Dowling, An Environmentally-Based Planning Model for Regional Tourism Development, "Journal of Sustainable Tourism", 1993, 1, pp. 7-37.

D. Dredge, J. Jenkins, Tourism Planning and Policy, Brisbane, John Wiley and Sons, 2007.

C. Emanuel, R. Afferni, Piano d'Azione per lo sviluppo della promozione, dell'accoglienza e dell'informazione turistica nella Provincia di Novara, Vercelli, Mercurio, 2009.

J. Friedmann, C. Weaver, Territory and Functions. The Evolution of Regional Planning, Londra, E. Arnold, 1979.

J. Friedmann, Empowerment. The Politics of Alternative Development, Cambridge, Basil Blackwell, 1992.

C.R. Goeldner, J.R. Brent Ritchie, Tourism: principles, practices, philosophies, New Jersey, John Wiley and Sons, 2008.

F. Governa, Il milieu urbano: l'identità territoriale nei processi di sviluppo, Milano, Angeli, 1997.

C.A. Gunn, Tourism Planning: Basics Concepts Cases, New York, Taylor and Francis, 1994.

C.M. Hall, Introduction to Tourism in Australia: Impacts, Planning and Development, Melbourne, Longman, 1995.

C.M. Hall, Tourism Planning, Policies, Processes and Relationships, Harlow, Pearson Education, 2000; Second edition, Prentice Hall, 2008.

C.M. Hall, Tourism: rethinking the social science of mobility, Harlow, Prentice Hall, 2005. 
C.M. Hall, J. Jenkins, Tourism and Public Policy, Londra, Routledge, 1995.

C.M. Hall, S.J. Page, The Geography of tourism and recreation: environment, place, space, Londra, Routledge, 2006.

C.M. Hall, S.J. Page, Progress in tourism management: from the geography of tourism to geographies of tourism, "Tourism Management", 2009, 30, pp. 3-16.

C.M. Hall, A. Williams, Tourism and Innovation, Londra, Routledge, 2008.

P. Healey, Collaborative Planning: Shaping Places in Fragmented Societies, Londra, Macmillan, 1997.

K. Hollinshead, The Powers Behind Play: The Political Environments for Recreation and Tourism, "Australia Journal of Park and Recreation Administration", 1990, 8, pp. 35-50.

E. Inskeep, Tourism planning: An integrated and Sustainable Development Approach, New York, Van Nostrad Reinhold, 1991.

M. Kenny, J. Meadowcroft (eds), Planning Sustainability, Londra, Routledge, 1999.

B. King, M. Pearlman, Planning for tourism at local and regional levels: principles, practices and possibilities, in T. Jamal, M. Robinson, The SAGE Handbook of Tourism Studies, Londra, Sage Publications, 2009, pp. 416-431.

A. Lanzani, Tra analisi sociale e indagine morfologica, in A. Clementi, G. Dematteis, P.C. Palermo (a cura di), Le forme del territorio italiano. I. Temi e immagini del mutamento, Roma-Bari, Laterza, 1996, pp. 186-206.

F. Lawson, M. Baud-Bovy, Tourism and Recreation Development, Boston, CBI, 1977.

N. Leiper, Tourism Systems: an interdisciplinary perspective, Palmerston North (NZ), Massey University, 1990.

L.J Lickorish, C.L. Jenkins, An Introduction to tourism, Oxford, Butterworth Heinemann, 1997.

P.T. Long, J.S. Nuckolls, Organising resources for rural tourism development: The importance of leadership, planning and technical assistance, "Tourism Recreation Research", 1994, 2, pp. 19-34.

C. Marien, A. Pizam, Implementing Sustainable Tourism Development Through Citizen Participationin the Planning Process, in S. Wahab, J.J. Pigram, Tourism, Development and Growth. The Challenge of Sustainability, Londra, Routledge, 1997, pp. 164-178.

P. Mason, Tourism Impacts, Planning and Management, Oxford, Butterworth Heinemann, 2003.

H.R. Maturana, F.J. Varela, L'albero della conoscenza, Milano, Garzanti, 1987.

S.F. McCool, R.N. Moisey (eds), Tourism, Recreation and Sustainability: Linking culture and the Environment, Wallingford (UK), CAB International, 2001.

D.H. Meadows, J. Randers, I limiti dello sviluppo, Milano, Mondadori, 1972. 
R.E. Mitchell, D.G. Reid, Community integration: Island tourism in Peru, "Annals of Tourism Research", 2001, 1, pp.113-39.

R. Monypenny, Capacity building through cooperation, in G. Moscardo (ed), Building Community Capacity for Tourism Development, Wallingford, CABI, 2008, pp. 155-171.

G. Moscardo (ed), Building community capacity for tourism development, Wallingford, CABI, 2008.

P. Murphy, Tourism: A Community Approach, New York, Methuen, 1985.

R. Normann, Managing for growth, Chichester, Wiley, 1977; trad. it, Le condizioni di sviluppo dellimpresa, Milano, Etas, 1979.

S. Pike, Destination Marketing Organisation, Oxford, Elsevier, 2004.

M. Polanyi, The Tacit Dimension, Londra, Routledge, 1966.

R.B. Potter, T. Binns, J.A. Elliot, D. Smith, Geographies of development, an introduction to development studies, Harlow, Pearson Education, 2008.

M. Purvis, A. Grainger, Exploring Sustainable Development: Geographies perspective, Londra, Sage, 2004.

G. Saxena, Relationships, networks and the learning regions: case evidence from the Peak District National Park, "Tourism Management", 2005, 2, pp. 277-289.

G. Shaw, A.M. Williams, Critical Issues in Tourism: A Geographical Perspective, Oxford, Blackwell, 1994.

R. Simeon, Studying Public Policy, "Canadian Journal of Political Science", 1976, 4, pp. 558-580.

S. Singh, D.J.Timothy, R.K. Dowling (eds), Tourism in Destination Communities, Wallingford, CABI, 2003.

W.B. Sthör, D.R.F. Taylor, (eds), Development from Above or Below? The Dyalectics of Regional Planning in Developing Countries, Chichester, J. Wiley, 1981.

M. Storper, A.J. Scott (eds), Pathways to Industrialization and Regional Development, Londra, Routledge, 1992.

E. Swyngedouw, Glocalisations, Philadelphia (PA), Temple University Press, 2004.

D.J. Timothy, Tourism and political boundaries, Londra, Routledge, 2001.

A.Turco, Configurazioni della territorialità, Milano, Angeli, 2010.

K. Walker, Tools to Enhance Community Capacity to Critically Evaluate Tourism Activities, in G. Moscardo (ed), Building Community Capacity for Tourism Development, Wallingford, CABI, 2008, pp. 86-100.

S. Williams, Tourism Geography, a new synthesis, London, Routledge, 2009. 


\section{La declinazione della sostenibilità al turismo}

Anna Tanzarella

Sostenibilità e turismo. Un'introduzione. - Il rapporto fra sostenibilità e turismo si propone nei termini di una relazione molto complessa che ha dato vita negli ultimi anni a riflessioni e dibattiti fra studiosi di diverse discipline. La definizione stessa di sostenibilità si deve ad un processo di consapevolezza che ha portato al ripensamento critico del modello di crescita economica dominante - quello industriale fordista - ed ha avuto il merito di legare le riflessioni sui processi di sviluppo al dibattito internazionale sulla "questione ambientale" (Conti, 1996; Tinacci Mossello, 2008). Dai timori sui mutamenti climatici globali e sulla riduzione della biodiversità, si è avviata la ricerca verso nuove modalità di sviluppo che, a partire dagli anni Settanta, hanno trovato confronto nei tavoli di lavoro internazionali dove è stato definito il quadro teorico ed analitico del concetto di sviluppo sostenibile.

Questa rinnovata consapevolezza socio-politica riflette in realtà il passaggio ad un nuovo approccio nella considerazione dei rapporti società-ambiente, che si è tradotto nell'ambito delle scienze geografiche nella maggiore autonomia di indagine delle politiche per l'ambiente (Leone, 1987; Vallega, 1994). Si è compreso, che 
il raggiungimento di efficaci politiche di sostenibilità non può esaurirsi nella determinazione di vincoli di tutela e salvaguardia degli ecosistemi naturali, bensì deve integrare prospettive olistiche per il governo e la gestione dei territori, specie alla scala locale. Pertanto, si è andata accentuando la prospettiva che la sostenibilità non è un concetto solo ecologico e, quindi, di mera gestione degli equilibri ambientali.

Riflessioni critiche sulle regole generatrici del modello economico tradizionale, fortemente sbilanciato nella distribuzione della ricchezza, nelle modalità di accesso ai mercati e nelle opportunità di sviluppo, aprono ad una rinnovata consapevolezza che si concretizzerà nella definizione del concetto di sviluppo sostenibile, enunciato in ambito internazionale nelle conferenze periodiche organizzate dall'ONU sulle tematiche di ambiente e sviluppo.

E' a partire dalla Conferenza di Rio de Janeiro del 1992 che il turismo riceve una menzione specifica nel dibattito a scala mondiale sulla sostenibilità e si avvia a divenire una voce importante nelle politiche destinate al raggiungimento dello sviluppo sostenibile. Se il turismo per molti versi viene ancora identificato quale principale responsabile degli squilibri ambientali, esso rappresenta sempre più il riferimento obbligato per l'avvio di progetti di recupero e valorizzazione del patrimonio territoriale (aree protette e parchi nazionali, nuclei industriali dismessi, quartieri urbani). I soggetti coinvolti nel turismo possono stimolare processi di salvaguardia e valorizzazione delle risorse territoriali, alimentando circuiti positivi di investimento in infrastrutture, servizi, promozione.

Negli ultimi decenni la sostenibilità è diventata pertanto "condizione" essenziale per il raggiungimento di un elevato livello di competitività nei processi turistici ed è stata associata ad un'accezione fortemente "territorializzata", inserendosi in un approccio teorico largamente condiviso che considera la scala locale 
e il territorio come riferimenti essenziali per implementare percorsi di sviluppo locale sostenibile.

Dunque, il turismo cambia e va strutturandosi in accezioni più complesse che coinvolgono motivazioni multiple di viaggio, varietà degli spazi di fruizione, flessibilità nell'organizzazione dei prodotti e dei servizi offerti. Nell'ambito delle scienze geografiche, la declinazione dell'approccio sostenibile al turismo ha riproposto quest'ultimo come fattore di sviluppo territoriale (Dansero, 2007), sostenendo, accanto alla sfera ambientale, il ruolo centrale delle dimensioni culturali, economiche e sociali.

Un significato più estensivo, dunque, che si riflette sia nella maggiore coscienza ecologica degli operatori della filiera del turismo e della domanda, ma che trova compimento da un lato in forme di tutela e strumenti di salvaguardia (istituzioni di parchi e aree naturalistiche, creazione di ecomusei, adozione di certificazioni ambientali e marchi di qualità), dall'altro nella consapevolezza del valore delle culture materiali e immateriali e nel rispetto delle comunità locali.

Dallo sviluppo sostenibile al turismo sostenibile. - La pubblicazione del rapporto del Club di Roma intitolato "I limiti dello sviluppo" (Meadows, Randers, 1972) rappresenta il punto di avvio di una riflessione globale sui limiti della crescita. Il lavoro ha evidenziato la pressante necessità di affrontare il problema dei limiti dell'ambiente esponendo ipotesi catastrofiche sull'esauribilità delle risorse disponibili al XXI secolo e proponendo come indispensabile inversione di rotta un azzeramento della crescita. Il lavoro mette in relazione cinque variabili (popolazione, produzione industriale, risorse naturali, inquinamento, produzione alimentare), mostrando le conseguenze dannose a scala globale del sistema economico dominante sull'esauribilità delle risorse del pianeta, introducendo prospettive neomalthusiane. 
In questa prospettiva il concetto di sostenibilità può essere declinato in due forme a seconda della considerazione delle componenti ambientale ed economica:

- la sostenibilità forte: ritiene che le risorse appartenenti al capitale naturale non possano essere sostituite in alcun modo con le componenti del capitale economico e che debbano essere mantenute entro una soglia critica onde evitare il rischio di collasso del sistema. I sostenitori della sostenibilità forte promuovono il contenimento dei consumi e delle emissioni, assumendo come principio essenziale la sostenibilità ambientale. Il raggiungimento di questo obiettivo prevede cambiamenti radicali nella produzione, nei comportamenti di consumo, nel lavoro e nei rapporti sociali, a partire dall'utilizzo di risorse rinnovabili;

- la sostenibilità debole: consente un certo grado di sostituibilità delle risorse naturali con il capitale fisico, se il risultato porta ad un aumento di valore per il sistema. L'accento è posto sulla sostenibilità economica e sulla capacità delle innovazioni tecnologiche di riuscire a produrre condizioni ottimali di mantenimento del sistema. 


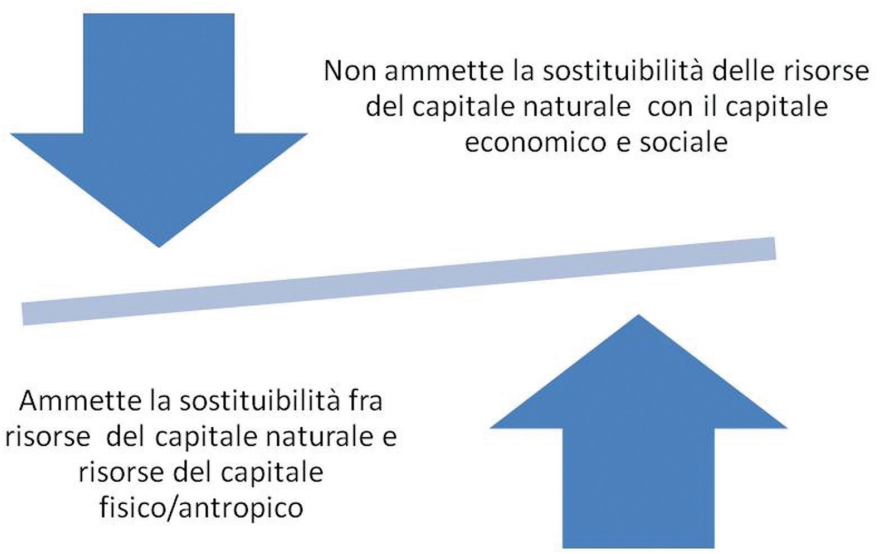

Fig. 1 - La sostenibilità forte e la sostenibilità debole. Fonte: elaborazione dell'Autrice

Nella prima conferenza delle Nazioni Unite (Stoccolma, 1972) si arriva ad una definizione del concetto di sviluppo e alla consapevolezza dell'importanza delle azioni di tutela e responsabilità dell'uomo in relazione all'ambiente e alle generazioni future.

Il concetto di sviluppo sostenibile appare per la prima volta nella pubblicazione Our common future, elaborato dalla Conferenza delle Nazioni Unite nel 1987 (Protocollo di Montreal) e nota come Rapporto Brundtland, dal nome della primo ministro norvegese che presiedeva i lavori. La Commissione sviluppa contenuti programmatici che si fondano sulla consapevolezza di una "sostenibilità al plurale", ossia sulla necessaria complementarietà delle dinamiche di crescita economica (sostenibilità economica) con le esigenze di tutela ambientale (sostenibilità ambientale) e di sviluppo sociale e culturale (sostenibilità sociale), come condizioni vitali alla "soddisfazione dei bisogni delle attuali generazioni senza compromettere le capacità di quelle future di rispondere ai loro" (WCED, 1987). 
Il Rapporto Brundtland "propone una nuova categoria al pensiero e all'azione sociale, che senza negare la dinamica socioeconomica, la aggancia in maniera indissolubile all'obiettivo della costruzione di un futuro possibile, equo e durevole per il genere umano" (Tinacci Mossello, 2008, p. 71) e ancora "la commissione Brundtland assume in modo corretto il concetto di sviluppo, inteso come trasformazione culturale, tecnica, sociale e istituzionale oltre che economica, ma non esclude la crescita economica (...) (ibidem, p. 72). L'esito dei cambiamenti interpretativi avvenuti nella lettura delle "leggi" che governano lo sviluppo economico mondiale si concretizza così nella tensione verso un modello di sviluppo diverso che valuta i livelli di sviluppo di un Paese (affidati notoriamente al calcolo del PIL), mediante ordini di grandezza differenti da profitto, produttività e spesa per i consumi per considerare, piuttosto, i miglioramenti nella qualità della vita e valori culturali, etici e sociali, come l'equità, l'integrità dell'ecosistema e l'efficienza (Vallega, 1994).

Il rapporto Brundtland ha rappresentato il documento programmatico di base all'avvio della Conferenza mondiale delle Nazioni Unite su Ambiente e Sviluppo tenutasi a Rio de Janeiro nel 1992 (Earth Summit). Obiettivi della Conferenza sono stati la definizione di strategie comuni e l'elaborazione di prassi operative condivise per il raggiungimento delle politiche di sviluppo sostenibile. Lo strumento principale di programmazione è stato individuato nell'Agenda 21, un documento contenente le linee guida delle problematiche da affrontare e le azioni coerenti da perseguire entro il XXI per arrestare i processi di degrado ambientale. L'integrazione fra dimensione economica, sociale ed ambientale si ritrova nei presupposti del secondo Summit mondiale delle Nazioni Unite e del Piano per lo sviluppo sostenibile di Johannesburg nel 2002 (noto come Rio+10). Si avverte in quell'occasione un'estensione del concetto di sviluppo sostenibile, accogliendo temi di carattere sociale come la lotta alla povertà, la promozione della salute, il rispetto dei diritti umani ma alcuni temi, come quello legato alla politica energetica, restano 
inevasi e chiara appare l'influenza delle logiche globali di commercio e finanza.

Numerose sono state le iniziative di incontro e partnership a livello europeo e nazionale che hanno portato la questione della sostenibilità al centro della programmazione comunitaria (Strategia di Lisbona, 2000), delle politiche pubbliche ed aziendali, dei documenti istituzionali e politici alle varie scale per l'accesso ai finanziamenti nazionali ed europei.

Negli ultimi decenni il concetto di sostenibilità ha assunto un significato estensivo che ha portato da un lato ad un allacciamento con le problematiche sociali e culturali, dall'altro ad un riconoscimento dell'importanza della dimensione locale come scala di individuazione delle problematiche e delle politiche di intervento (vedi infra). Se è indubbio che lo sviluppo sostenibile ha imposto un mutamento paradigmatico nel quadro strategico mondiale, è pur vero che sfugge ad una definizione univoca. Lo sviluppo sostenibile viene considerato da più parti come un ossimoro, o una dichiarazione di intenti programmatici, un'aspirazione alla quale tendere. Dubbi più o meno fondati sulla concreta applicabilità del concetto, sulla sua effettiva implementazione, infine, sullo scollamento fra teorizzazione e risultati operativi (from intent and implementation) hanno prodotto nuove formulazioni come la "teoria della decrescita felice" (Latouche, 2009).

Con l'estensione del concetto di sostenibilità al turismo, a partire dalla Conferenza di Rio del 1992, la questione ambientale è stata assunta con un ruolo crescente anche nelle politiche di sviluppo turistico. Si è avviato un processo che ha modificato lo studio e l'interpretazione dei fenomeni turistici, nonché l'organizzazione delle sue componenti. La comprensione di questi mutamenti è affidata alle basi teorico-metodologiche messe a punto da Jafar Jafari (1989) e riprese da Weaver (2004). Le quattro platforms individuate da Jafari - ciascuna con uno specifico apparato teorico e propri modelli di riferimento - mostrano le diverse posizioni (scientifiche 
ed economiche) assunte nei confronti del turismo e rappresentano quattro differenti approcci teorici allo sviluppo. Esse non vanno necessariamente lette in un'ottica diacronico-evolutiva poiché rimandano ad immagini che spesso hanno convissuto e tuttora convivono nel pensiero scientifico e nelle teorie economiche allo sviluppo. La riflessione così articolata è utile a svelare il percorso evolutivo che ha condotto all'elaborazione del concetto di turismo sostenibile.

1. Advocacy Platform. Fra gli anni Cinquanta e Sessanta del secolo scorso si afferma una posizione di sostegno alla lettura dei fenomeni turistici. Il turismo si va legando ad interpretazioni che valorizzano il suo ruolo di generatore di ricchezza e di volano dello sviluppo economico. Un'impostazione questa, che si situa nel quadro della teoria economica della modernizzazione, allora dominante (Rostow, 1960) e basata su un'idea fortemente polarizzata di sviluppo nella quale un nodo centrale (un'area urbana) diventa fulcro di attività specializzate e competitive ed è in grado di produrre effetti diffusivi nei confronti di aree spazialmente periferiche, fino a raggiungere la progressiva modernizzazione dell'intera regione. Un rapporto centro/periferia che vede il governo del territorio intervenire mediante la creazione di poli di sviluppo strategicamente localizzati e in grado di produrre processi di crescita moltiplicativi. In questa prospettiva che introduce una concezione accentrata dei modelli e delle politiche di sviluppo, il turismo, come moltiplicatore di processi propulsivi, è in grado di stimolare effetti positivi a cascata (trickling-down) nei confronti delle aree esterne al core ma dotate di rilevanti risorse naturali e culturali. L'accostamento alla teoria della modernizzazione implica un forte credito nei confronti del turismo di massa, "regolato" da dinamiche di laissez-faire (di autonomia dei processi) (Jafari, 2001), e una estesa fiducia nel ruolo giocato dal sistema capitalista nel processo di sviluppo. 
2. Cautionary Platform. Dagli anni Settanta si sviluppa un atteggiamento scientifico di riflessione nei confronti degli impatti ambientali, economici e socio-culturali prodotti dal turismo, anche come reazione alle contraddizioni prodotte dal turismo di massa.

Il paradigma dominante negli studi sul turismo degli anni Settanta è ispirato alla teoria della dipendenza (Finney, Watson, 1975) dove il rapporto centro/periferia diventa sinonimo di squilibri fra sistemi territoriali e dove le aree periferiche si configurano sempre più come sistemi aperti passivi ricettori di dinamiche provenienti dall'ambiente esterno, ma dipendenti da forze esogene che esercitano forme di controllo sulle risorse territoriali. Per alcuni studiosi, il turismo viene così ricondotto all'espressione di relazioni neocoloniali di potere (Britton, 1982).

Il concetto di sostenibilità non è ancora assunto nello scenario delle riflessioni mondiali ma i sostenitori di questa posizione ritengono il turismo di massa evidentemente insostenibile e promuovono un ideale di sviluppo fondato su una maggiore qualità della vita, più attento alle dinamiche presenti alla scala locale $\mathrm{e}$ meno dipendenti dalle variabili economiche tradizionali.

3. Adaptancy Platform. All'inizio degli anni Ottanta si avvia la nascita di un programma di adeguamento che prende le distanze dalle convenzioni del turismo di massa per promuovere forme di "turismo alternativo" orientate all'equilibrio dei processi di sviluppo e al coinvolgimento delle comunità locali. La diffusione di tipi-ideali di turismo come il turismo soft, il turismo verde, il turismo responsabile, il turismo sensibile, ecc. rappresenta la naturale conseguenza di un processo di allontanamento dalla domanda di turismo di massa e l'avvento di nuovi segmenti turistici. Le nuove percezioni di sviluppo del turismo immaginate dall'Adaptancy platform muovono dalle considerazioni dei limiti dello sviluppo (Limits to growth) che negli stessi anni trovava una prima collocazione scientifica nel rapporto del Club di Roma 
(Meadows, Randers, 1972), riflessione provocatoria per l'avvio dei dibattiti che, a partire dagli anni Ottanta, si indirizzeranno alla risoluzione delle problematiche ambientali a scala globale attraverso l'adozione del concetto di sviluppo sostenibile.

4. Knowledge-Based Platform. Secondo lo studio di J.Jafari (1989), a partire dagli anni Novanta si palesa un nuovo orientamento scientifico allo studio del turismo che cerca di sanare le contraddizioni che hanno caratterizzato le posizioni teoriche precedenti, fondandosi su nuove prospettive di ricerca e orientate ad un approccio olistico.

Concetti chiave di questa impostazione sono:

- la dimensione territoriale locale, alla quale viene riconosciuta un'importanza fondamentale nella definizione dei processi di sviluppo turistico;

- il coinvolgimento delle comunità nelle dinamiche di gestione delle attività turistiche.

E' chiara la consapevolezza che le modalità ritenute più appropriate per sviluppare il turismo dipendano oramai dai caratteri specifici dei singoli contesti territoriali, dalla capacità di sviluppare, nel rapporto ricorsivo fra domanda e offerta, forme di sostenibilità che coinvolgano complessivamente tutte le dimensioni del territorio (ambientale, culturale, economica, ...).
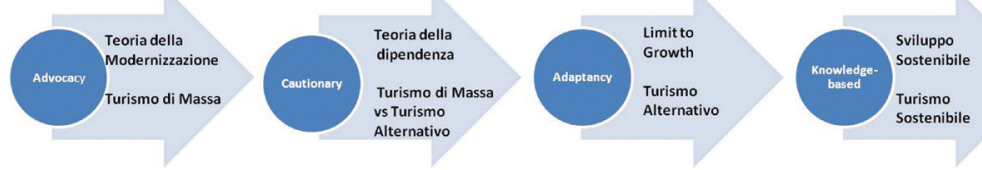

Fig. 2 - Le platforms di Jafari (1989). Fonte: elaborazione dell'Autrice 
Pertanto, un approccio critico allo studio del turismo accompagna la formulazione del concetto di turismo sostenibile, inteso come quello sviluppo "che deve essere ecologicamente sostenibile nel lungo periodo, economicamente conveniente, eticamente e socialmente equo nei riguardi delle comunità locali" (art. 1 della Carta di Lanzarote, 1995). La definizione produce un progressivo spostamento di senso dal turismo come minaccia ai "turismi" come risorse e opportunità.

Se, come visto inizialmente, il focus delle ricerche era incentrato sull'ambiente naturale e sui problemi legati al deterioramento fisico delle risorse e all'inquinamento, in un secondo momento, oltre agli impatti ambientali, iniziano ad essere prese in considerazione anche altre componenti territoriali riconoscendo, pertanto, l'importanza delle diverse dimensioni della sostenibilità - fisica, economica, sociale, culturale, istituzionale. Come afferma Oddi viviamo "in (...) un mondo ormai prevalentemente antropizzato - anche se con livelli differenti - nel quale la ricerca della sostenibilità non può ridursi a un'aspirazione alla pura naturalità, ma deve tradursi, anzi, in un'azione di difesa del patrimonio storico-culturale e testimoniale dell'operato dell'uomo, comparata con le esigenze della preservazione degli ecosistemi naturali oltre che, ovviamente, nella costante ricerca di un corretto equilibrio tra le continue trasformazioni generate dai processi antropici e l'ambiente" (Oddi, 2009, p. 13).

Per semplificare, gli impatti ricondotti al turismo sono stati distinti in tre categorie che racchiudono la componente fisicoambientale, socio-culturale ed economica:

- fisico-ambientale: include la compromissione ambientale, l'inquinamento atmosferico e acustico, i sovra-consumi idrici ed energetici, l'aumento dei rifiuti, il consumo di suolo, il sovraffollamento, la cementificazione edilizia, ecc.;

- socio-culturale: considera le dimensioni di contatto/ conflitto fra pratiche turistiche e cultura locale, come il comportamento "coloniale" del turista e l'atteggiamento 
di chiusura localistica della comunità locale. Inoltre, la spettacolarizzazione della realtà locale con forme di folklore costruite a fini di consumo del turista, perdita di identità e di controllo da parte della popolazione (no potere decisionale), banalizzazione del commercio, dell'artigianato e dell'offerta gastronomica o scomparsa di attività tradizionali per l'avvio di attività legate al turismo (effetto crowding down - spiazzamento) (Casari, 2008);

- economica: prevede dimensioni quali l'aumento del costo della vita e dei prezzi al consumo, la presenza di un doppio circuito dei prodotti e dei servizi fra turisti e residenti, formule di lavoro stagionale e non regolarizzato, modesti vantaggi economici locali.

La valutazione degli impatti del turismo può essere affidata alla capacità di carico che è uno dei più complessi approcci utilizzati per la comprensione della capacità delle destinazioni turistiche di sopportare certi livelli di utilizzo (Coccossis, 2004). Il concetto di capacità di carico ha valore perché disegna i limiti ed i livelli oltre i quali non è desiderabile andare, pena il superamento di una soglia critica e la compromissione della qualità della relazione e dell'equilibrio fra domanda e risorsa e/o destinazione. Il livello di utilizzo di una risorsa viene, pertanto, sostenuto fin quando non si rilevano implicazioni sul deterioramento delle caratteristiche e della qualità della risorsa stessa o dell'esperienza di utilizzo.

Questo determina quattro tipi di capacità di carico (WTO, 2004) che riflettono il concetto estensivo di sostenibilità. L'accezione "fisica" di capacità di carico è principalmente una misura quantitativa del numero di persone o utilizzo che un determinato sito può sopportare a livello di affollamento e congestione. La concezione "economica" è connessa soprattutto ai molteplici usi di una risorsa e alle implicazioni relative alla gestione delle risorse e ai più ampi 
obiettivi strategici della risorsa nel suo complesso. La nozione "ecologica" (o capacità ambientale) interessa principalmente l'utilizzo della risorsa in rapporto agli ecosistemi naturali prima che si verifichi un declino inaccettabile e irreversibile dei fattori biologici e fisici. Infine, il concetto di capacità di carico "sociale" pone l'accento non solo sulla parte quantitativa, relativa al numero dei visitatori, ma anche sulla parte qualitativa dell'esperienza turistica, andando a valutare la percezione dei visitatori, il significato di utilizzo, il livello di soddisfazione, il rapporto tra i turisti e la comunità ospitante. Il concetto ha fornito un contributo metodologico importante per la gestione delle risorse e la definizione degli indicatori da impiegare.

Nel tentativo di catturare i cambiamenti che dagli anni Novanta iniziano a caratterizzare le dinamiche turistiche sono stati coniati nella letteratura internazionale diversi termini per indicare i nuovi segmenti di turismo environmentally oriented come turismo natura, turismo verde, ecoturismo, turismo soft, turismo responsabile, turismo sostenibile (Leslie, 2009). Un numero sempre maggiore di turisti esprime comportamenti più consapevoli e riflessivi dietro l'influenza dei dibattiti internazionali sulla responsabilità ambientale e l'avvento di questi nuovi segmenti di turismo può essere ricondotta, secondo alcuni studiosi (Poon, 1993), ai mutamenti nel sistema economico delle società occidentali, caratterizzate da fenomeni di deindustrializzazione e dematerializzazione della produzione. La transizione dal modello fordista al post-fordista è stata accompagnata da altrettanti mutamenti nei quadri sociali e culturali (dinamiche del lavoro accelerate, nuove professionalità, più tempo libero, ecc.) con l'aumento delle classi sociali medie impiegate in attività e servizi dell'economia post-industriale (Hughes, 2004).

Pertanto, la nascita di nuove forme di turismo deve essere letta nel quadro di questi mutamenti che hanno profondamente modificato le caratteristiche e i comportamenti dei consumatori. I nuovi turisti (Robinson, Novelli, 2005) ricercano un'esperienza a contatto con l'ambiente naturale, sociale e culturale nel rispetto delle tradizioni 
delle comunità locali. Poon ritiene che ci sarà il progressivo abbandono delle formule di turismo di massa a favore di queste nuove tipologie di consumatore, e che ciò sarà inevitabile alla luce delle profonde trasformazioni del mercato, della diversificazione dei consumi, dell'accesso alle tecnologie. Pertanto, la nascita di un nuovo turismo sembrerebbe porsi come il riflesso delle nuove opportunità di mercato.

$\mathrm{Nel}$ mondo scientifico la condivisione su queste nuove categorie di domanda turistica non è unanime e l'ambiguità del concetto stesso di turismo sostenibile, ritenuto da alcuni studiosi un ossimoro difficile da combinare, ha portato ad avanzare nuove proposte terminologiche. Per esempio, Hughes propone il termine di turista riflessivo (reflexive tourist) per definire non un particolare tipo di pratiche di consumo turistico, bensì un nuovo modo in cui il turismo è consumato. La riflessività come risposta alla post-modernità dei processi, come adattamento ai comportamenti responsabili nei confronti dell'ambiente, come stile di vita a supporto del bene comune. Al di là dei termini coniati è ormai condiviso l'assunto che il raggiungimento di un turismo più consapevole e responsabile, di un turismo sostenibile appunto, debba essere definito non solo dalla domanda ma debba implicare il pieno coinvolgimento delle imprese che appartengono alla filiera dell'offerta turistica (Hall, Gossling, 2009). Gli operatori turistici sono chiamati ad adottare misure adeguate nel processo di organizzazione delle fasi aziendali per contribuire al raggiungimento di una maggiore sostenibilità ambientale, sociale ed economica. E' nell'incontro fra produttore e consumatore che si realizza lo scambio utile alla realizzazione di servizi turistici in linea con gli obiettivi delle diverse dimensioni di sostenibilità.

Verso un concetto di sostenibilità alla scala locale. - Il superamento del tradizionale modello di sviluppo economico fondato sulla polarizzazione/concentrazione di risorse nei settori produttivi industriali e sulla impostazione esogena e gerarchizzata delle dinamiche di intervento si è accompagnato ad un diverso modo di orientare le politiche di governo del territorio e di promozione dello sviluppo che 
hanno assegnato un ruolo predominante alla dimensione territoriale locale (Magnaghi, 2000; Dematteis, Governa, 2005). Il territorio non è più visto come proiezione passiva di progetti ed interventi imposti dagli enti istituzionali, secondo una dinamica top-down, ma diventa 'soggetto' attivo delle iniziative di sviluppo orientate al cambiamento e all'innovazione, specie alla scala locale (bottom-up). La consapevolezza della centralità del territorio nei cambiamenti indotti dalla globalizzazione si è tradotta in un ripensamento delle logiche di intervento, in una marcata tendenza alla territorializzazione dei processi di sviluppo e ad una maggiore contestualizzazione delle politiche territoriali, basate sulla considerazione delle potenzialità endogene dei contesti locali. Lapproccio territoriale allo sviluppo locale "si basa sul presupposto che lo sviluppo locale derivi dal rapporto di territorialità che lega, in un processo interattivo di lunga durata, una società e un territorio" (Dematteis, Governa, 2005, p. 26). La crisi di un approccio funzionale allo sviluppo che uniforma strumenti, pratiche e politiche di intervento senza cogliere le diversità economiche, sociali, culturali espresse dai singoli contesti territoriali, spinge a riscoprire la dimensione locale come unità di analisi (Friedmann, 1992; Governa, 2010). Il locale si mostra come livello territoriale ottimale per garantire la compatibilità delle scelte di sviluppo con le peculiarità del patrimonio territoriale, promuovendo l'inserimento delle risorse endogene nei processi di sviluppo socio-economico e culturale. L'estensione del concetto di sostenibilità a dimensioni che non siano solo ambientali nel senso ecologico del termine si fonda, quindi, su un ruolo attivo del territorio nei processi di sviluppo locale. E' di fronte alla spinta dei mercati mondiali e alla tendenziale pervasività dell'economia post-industriale, che i territori considerati marginali nei modelli della gerarchia funzionale fra aree centrali e periferiche, iniziano a rivestire il ruolo di nuove centralità economico-culturali, per la capacità di riuscire a proporsi come agenti dei processi di sviluppo attraverso la messa in valore di risorse endogene, tangibili e intangibili, el'auto-organizzazione dei soggetti locali. 
$\mathrm{Si}$ propone pertanto la ricerca di nuovi paradigmi, nuovi modelli organizzativi che si vanno strutturando non a livello globale e nelle strategie delle grandi istituzioni "ma nella profondità del locale, là dove operano (...) attori sociali che hanno saputo inventarsi nuove tattiche e pratiche territoriali oltre che nuovi progetti per gestire e valorizzare i beni comuni: risorse ambientali e paesaggi diventati rari, ma sempre più necessari” (Quaini, 2010, p. 56).

Questa una nuova soggettività territoriale non è sinonimo di chiusura localistica, ma si manifesta piuttosto nel tentativo di inserire la dimensione locale nell'arena competitiva dei processi di sviluppo, cercando la convergenza fra interessi espressi alla scala locale, risorse endogene e rapporti con le dimensioni sovra locali. Si ritiene che "i programmi e le azioni che riescono a inserirsi in questa dinamica coevolutiva e a sfruttarne le potenzialità possono ottenere un valore aggiunto in termini di sostenibilità, efficacia e legittimità" (Dematteis e Governa, 2005). Oggi proprio perché la competizione si gioca su flessibilità, qualità e innovazione assume rilevanza, a sostegno delle differenze territoriali, l'immobilità di alcuni fattori, ovvero quei fattori che si legano a certe caratteristiche locali sia materiali che immateriali. Sono risorse specifiche irriproducibili, insieme di condizioni che costituiscono il prodotto storico dell'azione congiunta dei soggetti localizzati ed esprimono le seguenti caratteristiche (ibidem, p. 27):

- l'immobilità: risorse stabilmente ancorate/incorporate al territorio, i "fixed assets" individuati da Amin (2000);

- la specificità: risorse difficilmente reperibili altrove con le stesse qualità;

- la patrimonialità: risorse che si sedimentano nel territorio solo in un processo di medio-lungo periodo e che non sono riproducibili in tempi brevi (la dimensione temporale necessaria per garantire il valore storico-patrimoniale della risorsa). 
La dotazione territoriale, tuttavia, non è sufficiente a garantire l'attivazione di un processo di sviluppo e si richiede il coinvolgimento della sfera sociale e culturale e l'auto-organizzazione dei soggetti, poiché solo le risorse territoriali riconosciute nella loro valenza progettuale, trattenute e attivamente interpretate dagli attori territoriali, possono essere impiegate in nuove dinamiche di costruzione dell'ordine territoriale.

" $E$ ' necessaria dunque una rinascita, attraverso nuovi atti fecondanti, che producano nuovamente territorio, ovvero nuove relazioni fertili fra insediamento umano e ambiente. In questi atti territorializzanti c'è il germe di una vera sostenibilità dello sviluppo (...) in quanto ricerca rifondativa di relazioni virtuose, di nuove alleanze fra natura e cultura, fra cultura e storia" (Magnaghi, 2000, p. 10). Questo spinge a cogliere nei diversi contesti territoriali gli agenti del cambiamento, le componenti della territorialità "intesa come rapporto dinamico tra componenti sociali (economia, cultura, istituzioni, potere) e ciò che di materiale e immateriale è proprio dei territori dove si abita, si vive, si produce" (Dematteis e Governa, 2005, p. 17) che promuovono la valorizzazione locale e dal basso del patrimonio territoriale per trasformarlo in risorsa durevole da impiegare nei processi di produzione/riproduzione di territorio.

La componente relazionale e la partecipazione della comunità locale sono fondamentali nel "progetto locale" (Magnaghi, 2000), affinché i luoghi non vadano confusi con dei "simulacri, [delle] rappresentazioni teatrali o museali dell'identità passata, ma come potenziali produttori di nuova identità" (Magnaghi, 2003, p. 13) ed è attraverso il "progetto" che "passato, presente e futuro possono parlarsi” (Gambino, 1999, p. 28). In tal modo la valorizzazione non corrisponde ad un progetto di museificazione forzata e artificiosa, di conservazione nostalgica, ma si qualifica in un processo più complesso di patrimonializzazione, ossia di produzione/riproduzione di patrimonio per il raggiungimento di valore aggiunto territoriale (Emanuel e Vallaro, 2005). 
Questa impostazione scaturisce dai nuovi orientamenti teorici, politici e progettuali sul governo del territorio e sulla pianificazione/ gestione del paesaggio che esprimono una crescente attenzione nei confronti della tutela della biodiversità e della salvaguardia ambientale, del mantenimento dei caratteri e dei valori del paesaggio come fondamento per la valorizzazione delle identità locali.

La sostenibilità nei processi di sviluppo locale assume risvolti operativi qualora si rinvengano alcune condizioni prevalenti:

- modelli di sviluppo endogeno al fine di supportare le specificità territoriali e la contestualizzazione dei percorsi di sviluppo;

- processi cumulativi tra differenti livelli di scala geografica (nazionale, regionale, sovra locale, locale) per un'apertura dei sistemi verso l'esterno, e nello stesso tempo per una centralità della dimensione territoriale locale nei processi di sviluppo, la cui specificità è accentuata dal riconosciuto carattere autopoietico dei sistemi;

- modelli di Governance per supportare una territorializzazione delle politiche ambientali incentrata sulla contestualizzazione delle azioni e sul coinvolgimento e la partecipazione degli attori locali.

\section{Bibliografia}

A. Amin, The economic base of contemporary city, in G. Bridge, S. Waston (eds), A companion to the city, Oxford, Blackwell, 2000, pp. 115-129.

S.G. Britton, The political economy of tourism in the Third World, "Annals of Tourism Research”, 1982, 9, pp. 331-358.

R.W. Butler, Sustainable tourism: A State of the art review, "Tourism Geographies", 1999, vol. 1, pp. 7-25.

M. Casari, Turismo e geografia: elementi per un approccio sistemico sostenibile, Milano, Hoepli, 2008. 
H. Coccossis, Tourism and Carrying Capacity, London, Continuum, 2004.

S. Conti, Geografia economica. Teoria e metodi, Torino, Utet, 1996.

G.I. Crouch, J.R.B. Ritchie, Tourism, Competitiveness, and Societal prosperity, "Journal of Business Research", 1999, 44, pp. 137-152.

F. Dallari, Turismo tra sostenibilità ed etica, in E. Dansero, G. Di Meglio, E. Donini, F. Governa, Geografia, società, politica, La ricerca in geografia come impegno sociale, Milano, Angeli, 2007, pp. 83-96.

E. Dansero, Geografia e politiche per l'ambiente. Introduzione, in E. Dansero, G. Di Meglio, E. Donini, F. Governa, Geografia, società, politica, La ricerca in geografia come impegno sociale, Milano, Angeli, 2007, pp. 69-76.

G. Dematteis, Possibilità e limiti dello sviluppo locale, "Sviluppo Locale", 1994, 1, pp. 10-30.

G. Dematteis, F. Governa, Territorialità, sviluppo locale, sostenibilità: il modello SLoT, Milano, Angeli, 2005.

C. Emanuel, P. Vallaro (a cura di), Prove di sostenibilità. Progetti, piani e valutazioni per un processo di sviluppo urbano sostenibile a Novara, Novara Italgrafica, 2005.

B. Finney, K. Watson (eds), A New Kind of Sugar: Tourism in the Pacific, Honolulu, East-West Center, 1975.

J. Friedmann, Empowerment. The Politics of Alternative Development, Cambridge, Blackwell, 1992.

J. Friedmann, C. Weaver, Territory and Functions. The Evolution of Regional Planning, Londra, E. Arnold, 1979.

R. Gambino, Il paesaggio tra conservazione e innovazione, in A. De Rossi, G. Durbiano, F. Governa, L. Reinerio, M. Robiglio (a cura di), Linee nel paesaggio. Esplorazioni nei paesaggi della dispersione, Torino, Utet, pp. 22-31, 1999.

F. Governa, Ripensare il locale, ridefinire il territorio. Le possibilità di un approccio multidimensionale", in L. Viganoni (a cura di), A Pasquale Coppola. Raccolta di scritti, Roma, "Memorie della Società Geografica Italiana", 2010, pp. 723-735.

M. Hall, S. Gossling, Global environmental Change and Tourism Enterprise, in D. Leslie (ed), Tourism Enterprises and Sustainable development, London, Routledge, 2009.

G. Hughes, Tourism, Sustainability and Social, Theory, in A.A. Lew, M. Hall, A.M. Williams, (ed), 2004, pp. 498-509.

J. Jafari, The scientification of tourism, in V.L. Smith, M. Brent (eds), Hosts and Guests Revisited: Tourism Issues of the 21st Century, New York, Cognizant Communication Corporation, 2001, pp. 28-41.

J. Jafari, An English language literature review, in J. Bystrzanowsky (ed), Tourism as a Factor of Change: A Sociocultural Study, Vienna, Centre for Research and Documentation in Social Science, 1989, pp. 17-60.

S. Latouche, La scommessa della decrescita, Milano, Feltrinelli, 2009. 
U. Leone, Geografia per l'ambiente, Roma, Carocci, 1987.

D. Leslie (ed), Tourism Enterprises and Sustainable development, London, Routledge, 2009.

A.A. Lew, M. Hall, A.M. Williams (eds), A companion to tourism, Oxford, Blackwell, 2004.

A. Magnaghi, La rappresentazione identitaria del patrimonio territoriale, in G. Dematteis, F. Ferlaino (a cura di), Il mondo e i luoghi: geografie delle identità e del cambiamento, Torino, IRES, 2003, pp. 13-20.

A. Magnaghi, Il progetto locale, Torino, Bollati Boringhieri, 2000.

D.H. Meadows, J. Randers, I limiti dello sviluppo, Milano, Mondadori, 1972.

C. Oddi, Turismo e urbanistica, Milano, Hoepli, 2009.

G. Paba, Ipotesi iniziali di un'urbanistica ben temperata, in A. Magnaghi (a cura di), Il territorio dell'abitare. Lo sviluppo locale come alternativa strategica, Milano, Angeli, 1990, pp. 416-445.

A. Poon, Tourism, Technology and Competitive Strategies, Wallingford, CAB International, 1993.

M. Quaini (a cura di), Rapporto Annuale 2009. I paesaggi italiani. Tra nostalgia e trasformazione, Roma, Società Geografica Italiana, 2009.

M. Robinson, M. Novelli, Niche Tourism: an introduction: Niche Tourism contemporary issues trends and cases, London, Elsevier, 2005.

W. Rostow, The Stages of Economic Growth, Cambridge, Cambridge University Press, 1960.

M. Tinacci Mossello, Politica dell'ambiente. Analisi, azioni, progetti, Bologna, Il Mulino, 2008.

A. Vallega, Geopolitica e sviluppo sostenibile. Ilsistema mondo del secolo XXI, Milano, Mursia, 1994.

D. B. Weaver, Sustainable tourism, Theory and Practice, Oxford, Elsevier, 2006.

D.B. Weaver, Tourism and the Elusive Paradigm of Sustainable Development, in A. A. Lew, M. Hall, A.M. Williams (eds), 2004, pp. 510-521.

World Commission on Environment and Development (WCED), Our Common Future, ONU, 1987.

World Tourism Organization, Sustainable Tourism Development: Guide for Local Planners, Madrid, 1993.

World Tourism Organization, Agenda 21 for Travel \& Tourism Industry. Towards Environmentally Sustainable Development, Madrid, 1995.

World Tourism Organization, Indicators of Sustainable Development for Tourism Destination. A Guidebook, Madrid, 2004. 


\section{Come spremere acqua dalle pietre: un progetto a $360^{\circ}$. II caso dell'Orto dei Tu'rat come fattore ambientale e turistico}

Alessandro Macchia

Premessa. - I processi di produzione di energia dalle fonti rinnovabili hanno subito un'evoluzione senza precedenti, a tal punto che il paesaggio di molte regione d'Italia è mutato in maniera sostanziale, a causa di installazioni provvisorie per la loro produzione.

Lacqua, il vento e il sole sono tutte "materie prime" in grado di fornire energia pulita, fornendo un'alternativa al tradizionale sfruttamento di risorse, nel segno intangibile della sostenibilità, che negli ultimi decenni hanno visto un netto consumo intensivo in quasi tutti i paesi del mondo, Medio Oriente compreso.

La risorsa acqua, invece, rappresenta da sempre la materia prima per eccellenza per la produzione di energia, ma allo stesso tempo è in grado di fornire alimentazione per il suolo e per le coltivazioni. In questottica si vuole mettere in primo piano questa risorsa, andando a porre l'attenzione verso un sistema idraulico in 
grado di prevenire la desertificazione e l'erosione, in una specifica area dell'Italia Meridionale.

Il Basso Salento, in Puglia, da sempre terra di confine tra est ed ovest, ha attraversato nei secoli, molteplici periodi di dominazione straniera, diventando il crocevia di razze e popoli provenienti da ogni parte del Mediterraneo. La mescolanza di razze non ha fatto altro che rendere eterogeneo il panorama delle tradizioni locali, andando ad intaccare il tessuto sociale e modificandolo in maniera sostanziale. È grazie a questa eterogeneità che oggi abbiamo differenti tradizioni sparse nei molteplici comuni che costituiscono il Basso Salento, accomunati però da quel magico e surreale legame sociale che gli rende unici.

In questo contesto si incanala un discorso più ampio, in cui ambiente, paesaggio e tradizioni popolari si amalgamano indistintamente per dar vita ad un prodotto nuovo, in grado di distaccarsi nettamente dalla contemporaneità.

Stiamo parlando dell'Orto dei Tu'rat, un parco ecologico di circa 17 mila mq situato in Puglia, con esattezza nel Basso Salento, nel comune di Ugento, sul versante ionico. L'omonima Associazione Culturale gestisce e cura questo progetto, con l'intento che possa avere risvolti positivi per combattere i fenomeni appunto erosivi e di desertificazione, molto noti in quest'area geografica. Non solo, la mission dell'Orto è quella di impedire la salinizzazione del suolo, causata dalla vicinanza (a poco meno di $3 \mathrm{~km}$ in linea d'aria) del Mar Ionio, mediante appunto delle installazioni create ad hoc che si riallacciano alla tradizione salentina e a quella medio-orientale.

La salinizzazione delle falde acquifere è soprattutto il risultato dell'eccessivo sfruttamento delle stesse causato dalle trivellazioni per creare pozzi per irrigazione.

L'Associazione Culturale "L'Orto dei Tu'rat" segue un progetto che tenta di riprodurre un'esperienza legata non solo alle tradizioni locali, ma vuole anche interfacciarsi con la storia dei popoli che vivevano in luoghi aridi come nel deserto del Negev, 
in Israele meridionale. Qui l'aridità e la desertificazione hanno condotto a sperimentare forme di gestione e controllo delle acque, mediante la raccolta delle stesse, attraverso sistemi di pietre per la condensazione e captazione di umidità.

L'idea dell'Orto dei Tu'rat nasce non solo per dare risposte e soluzioni ai problemi succitati, ma anche per una globale riqualificazione del territorio, entrando a far parte di una discussione più ampia sia sulla sostenibilità ambientale, sia sui valori del paesaggio.

Il lato invisibile dell'acqua. - Il Basso Salento, una vasta area della Regione Puglia, tra le più calde e aride dell'Italia Meridionale, soprattutto negli ultimi decenni, anche a causa dell'abbandono delle campagne e della migrazione di gran parte della popolazione giovanile verso il Nord Italia e i paesi esteri, ha da sempre dovuto far fronte al problema atavico della siccità. Questa, in modo particolare, è una delle cause della forte aridità e desertificazione del suolo, connessa anche alla scarsa presenza di bacini idrici e fluviali.

Lo sfruttamento intensivo delle campagne con piantagioni non autoctone, avvenuto almeno fino al secondo dopoguerra, ha provocato anche una sterilità del suolo e il suo conseguente allontanamento dei contadini dalla terra.

A questo non va dimenticato il boom economico che ha investito, anche se in maniera marginale ma importante, questa zona attorno agli anni ' 60 e '70 del secolo scorso. Il settore tessile e manifatturiero ha arricchito queste zone dal punto di vista economico, ma ha anche accresciuto la popolazione di alcuni centri urbani dell'entroterra, andando ad incrementare l'eterogeneo panorama urbano con gente proveniente dall'agro circostante.

Il succedersi dei decenni non ha fatto altro che aumentare il divario tra città e campagna, andando ad approfondire quel solco che già si era creato con la rinascita economica. La ventata di crisi del settore industriale ha indotto molte imprese a chiudere o a trasferirsi 
in Paesi fiscalmente ed economicamente più vantaggiosi, causando quindi una dispersione della popolazione operaia.

Mentre le campagne rimangono in totale abbandono, costellate da appezzamenti di ulivi secolari, in cui si pratica ancora oggi un'agricoltura più di sussistenza che di esportazione, la desertificazione e l'aridità continua a primeggiare e ad avanzare verso livelli critici.

Il progetto attuale dell'Orto dei Tu'rat, premiato nel 2012 da Legambiente all'interno dell'iniziativa Innovazioni intelligenti, si identifica nell'omonima associazione dal 2008, operando, anche se in piccolo, in una porzione di territorio nel Comune di Ugento, nell'area Ionica del Basso Salento, in un panorama di grandi difficoltà ecologiche.

L'essenza dei luoghi, della filosofia, degli studi sul progetto in se è stata approfondita grazie alla proficua intervista all'ideatore Cosimo Specolizzi, che ha messo in luce importanti aspetti e risultati delle sue ricerche compiute in questi anni. Grazie alla messa in opera di questi studi si è potuto allargare l'orizzonte della sostenibilità e della salvaguardia del suolo salentino, per combattere l'aridità di questo lembo di regione.

Il progetto nel complesso vuol dimostrare che è possibile fare "politica ecologica" al di fuori degli schemi tradizionali, seguendo caparbiamente un percorso di sostenibilità ambientale che guarda a ciò che la terra può offrire. La volontà è quella di far a meno di strumenti convenzionali, tralasciando i meccanismi che attanagliano il suolo, cercando di dare un contributo concreto al territorio mediante mezzi tradizionali, salvaguardando la natura e l'ambiente campestre.

L'Orto dei Tu'rat vorrebbe entrare a far parte di una discussione più ampia sul delicato problema della desertificazione, erosione e salificazione del suolo, tentando di coinvolgere in prima persona esponenti delle istituzioni locali e delle associazioni di categoria. 
L'area occidentale del Salento in cui è collocato l'Orto (precisamente sulla costa Ionica), è quella che durante l'anno solare registra i più bassi valori di pioggia.

I venti predominanti sono quelli caldi e umidi: lo Scirocco (che arriva da Sud-Est), poiché proveniente dal Bacino di Levante del Mar Mediterraneo, ed il Libeccio (che spira da SudOvest). Il secondo, molto più carico di umidità, attraversa il Mar Mediterraneo per circa 550 miglia marine e investe tutta la parte del Basso Salento. È proprio la sua direzione e la sua caratteristica di essere carico di umidità, che il Libeccio è il vento privilegiato per il suo sfruttamento e captazione mediante la realizzazione di strutture in pietra, appunto i Tu'rat (o mezze lune fertili), situate a $230^{\circ}$ direzione Sud-Ovest.

La forma e l'orientamento di queste strutture in pietra sono state studiate in modo tale da consentire la raccolta dell'umidità presente in questi venti, così da attuare una "irrigazione senza apporto meccanico, garantendo la realizzazione di un orto botanico con tutte le specie autoctone e naturalizzate del Salento".

Dietro la costruzione delle mezze lune in pietra, di altezza variabile da 1 a 3 metri, realizzate a secco senza l'aggiunta di alcun legante esterno, vi è uno studio preparatorio connesso a secoli e millenni di pratiche legate al passato, che è stato avviato anche sulla comprensione della natura carsica della pietra utilizzata, affinché si potesse concretizzare una produzione consistente di gocce di rugiada, appunto attraverso le nebbie e i venti umidi.

Luso della pietra di Alessano (un comune a circa $20 \mathrm{~km}$ da Ugento) tra le prime nella scala dei valori per compattezza e resistenza, subito dopo quella di Carrara, è stata quella che meglio si è prestata al progetto e ha rispecchiato gli studi effettuati precedentemente.

Lutilizzo di questa pietra, per la costruzione delle mezzelune, rientra in un contesto a bassissimo impatto ambientale, non solo perché è costituito da materiale di risulta degli scavi per la 
realizzazione dell'Acquedotto Pugliese risalente agli inizi del secolo scorso, ma anche perché questo materiale non è stato estirpato dal suolo, bensì trasportato dalle campagne di Alessano all'agro di Ugento, in una distanza di poco più di trenta chilometri.

Come funzionano questi "condensatori". - In sostanza si tratta di un impianto di captazione, condensazione e riutilizzo di arie umidi, brine e nebbie. Per ottenere ciò è risultato fondamentale il posizionamento di pietre in determinati assi anziché altri, per permettere che gli accumuli spugnosi fossero in grado di assorbire la brina notturna e, per colamento, rifornissero il terreno di umidità.

L'uso di questa tecnica e della concimazione è stato introdotto già durante l'antichità in molte zone aride del mondo, quali il deserto del Negev, i deserti degli Stati Uniti sudoccidentali e le aree secche del Perù, della Cina e della Nuova Zelanda Maori.

I massi che ricoprono il suolo rendono il terreno più umido, riducendo l'evaporazione dovuta dal calore del sole e dal vento, rompendo la crosta indurita del suolo, che altrimenti lascerebbe scivolare via l'acqua senza trattenerla. La roccia, a sua volta, riduce l'escursione diurna della temperatura, perché assorbe il calore solare durante il giorno e lo rilascia la notte; inoltre protegge il suolo dall'erosione attutendo l'impatto delle gocce di acqua piovana sul terreno.

La produzione di acqua attraverso questo sistema di percolamento, non solo combattela desertificazione, ma contribuisce ad arricchire di acqua dolce le falde acquifere e il suolo, molto ricco di sale a causa della vicinanza del Mar Ionio.

La formazione di acqua inoltre, oltre a rimediare ai danni della desertificazione e dell'aridità del suolo, collabora alla crescita delle specie autoctone, piantumate in prossimità di ogni mezza luna, rendendo ognuna una corte con un proprio percorso biologico.

Il loro inserimento all'interno di queste strutture non fa altro che dimostrare che questa tecnica è possibile ed è efficace per 
una irrigazione alternativa allo sfruttamento delle falde acquifere, evitando la costruzione di pozzi e vasche per la raccolta di acqua piovana, i quali rappresentano palesemente un chiaro sfruttamento delle risorse e del suolo.

Il progetto attuale dell'Orto dei Tu'rat. - Il progetto "Orto dei Tu'rat" prevede la realizzazione di un ecosistema sostenibile dal punto di vista paesaggistico e ambientale.

Il corpo dell'opera è caratterizzato principalmente da due tematismi inscindibili tra loro: diffusione della naturalità e diffusione della cultura locale, dell'arte e delle conoscenze sul sistema del paesaggio salentino.

Il modello si propone di sviluppare un esempio sostenibile di gestione delle risorse, mettendo in atto una serie di misure che agiscono attivamente sulla tutela e sull' incremento della biodiversità, sulla difesa dall'erosione e desertificazione del suolo, attraverso sistemi che tutelano i cicli idrogeologici. È possibile attuare questo processo mediante l'implementazione di modelli idrici e idraulici basati sulla riduzione del consumo di acqua potabile, attraverso un sistema ad hoc che prevede il recupero delle acque piovane mediante la condensazione di umidità atmosferica attraverso strutture in pietra (appunto Tu'rat).

$\mathrm{Si}$ tratta di un'opera complessa che può essere definita infrastrutturale poiché tesa a implementare una serie di piccole infrastrutture, necessarie sia alla socialità dei luoghi sia alla tutela ambientale e all'ecologia. Il paesaggio, quindi, ricopre un ruolo tutto nuovo, ossia essere una infrastruttura capace di facilitare il processo di produzione sociale.

Il progetto del parco ecologico diventa il modo in cui ognuno intende partecipare attivamente alla costruzione del territorio, salvaguardando il suolo e l'ambiente. Si sente, per tanto, la necessità di collegare saldamente il problema relativo alla protezione della 
natura e del paesaggio con la programmazione produttiva, agraria e turistica del territorio del Basso Salento.

Lopera attuale segue, da una parte, le regole implicite dettate dalla disciplina dell'ecologia del paesaggio per la riqualificazione dell'area con elevati requisiti di naturalità e funzionalità ecologica (introduzione di specie arboree e arbustive autoctone), al fine di apportare un sostanziale miglioramento degli equilibri ambientali, la difesa del suolo dall'erosione ed un complessivo ripristino degli equilibri idrogeologici; dall'altra, segue un percorso in cui attività culturali e artistiche possano amalgamarsi all'interno del parco, portatore di contenuti paesaggistici e storici.

Questo obiettivo è perseguito, finora, attraverso la riqualificazione di un terreno incolto con la ricostruzione di un bosco termofilo perseguendo il moderno approccio della multifunzionalità delle aree naturali e seminaturali.

L'intervento ha un profondo significato per la fruizione sostenibile del territorio (dedicato principalmente alla qualità della vita della popolazione locale e all'attrazione di un turismo naturalistico-ambientale e ricreativo) in grado di soddisfare la domanda sociale di paesaggio e di contribuire alla crescita culturale approfondendo le conoscenze ambientali.

Il concetto di parco che si vuole affermare e diffondere, con l'iniziativa complessiva dell'Orto dei Tu'rat, è quello di porzione privilegiata di un territorio che si estende e si impone come area destinata a soddisfare la crescente domanda. Una richiesta di socialità di paesaggio e di interessi meramente culturali, ricreativi ma soprattutto ecologici, connessi intrinsecamente con le comunità locali, distaccandole definitivamente dalle grigie realtà urbane, proiettandole verso un rinnovato vivere in comune.

Il progetto si pone come sintesi di spazi attrezzati non solo per la ricreazione, il benessere sociale, ma soprattutto con una esperienza nuova di vivere la natura e l'innovazione ecologica. Il disegno complessivo finora realizzato, mette in scena una cultura 
nuova basata tanto sull'ecologia del paesaggio quanto sull'arte contemporanea e sulle tradizioni popolari, vero filo conduttore che porta al rapporto con la società locale.

Le attività promosse all'interno e fuori del parco agricoloecologico, fanno attualmente riferimento ad esigenze di protezione degli ecosistemi naturali e dell'ambiente in senso generale; tutto ciò è possibile attraverso l'uso ricreativo dei luoghi, con una maggiore priorità allo sviluppo di attività agricole, silvoculturali e paesaggistiche, nonché alla promozione di attività tradizionali atte a favorire la crescita economica, sociale e culturale della comunità locale, in modo particolare attraverso eventi letterari e culturali.

Il progetto attuale affronta $\mathrm{i}$ temi relativi alla diffusione della naturalità, attraverso l'espansione della matrice agricola del paesaggio (così come previsto dalle linee guida del PTCP della Provincia di Lecce), dell'incremento della biodiversità attraverso il mantenimento dei frammenti di naturalità esistente e ne propone l'espansione, da una parte, attraverso la realizzazione di nuovi manufatti (muretti a secco che descrivono le corti) e, dall'altra, innescando un meccanismo di successione seriale della vegetazione autoctona, realizzando un vero e proprio giardino botanico.

Il complesso del Parco si fa garante nell'affrontare il grave problema dei processi erosivi, in espansione in questa zona, dando una risposta non solo in ambito locale, ma espandendo le politiche dell'uso razionale dell'acqua e la sua raccolta anche al territorio circostante.

La salvaguardia della biodiversità non riguarda soltanto gli habitat e le specie selvatiche, ma anche la diversità genetica delle specie coltivate e "allevate". L'erosione genetica che si osserva negli ultimi decenni è principalmente collegata alla specializzazione produttiva che ha generato la marginalizzazione, se non il completo abbandono, di molte specie rurali coltivate e quindi la loro sostituzione delle molteplici varietà locali con altre colture. 
Questo obiettivo è finalizzato a riconoscere, promuovere e sostenere un'agricoltura ecocompatibile che mantenga e consolidi attivamente e localmente gli attuali livelli di biodiversità; questo deve portare ad investire le comunità rurali di un ruolo che permetta loro di creare e preservare il paesaggio agrario e tutti gli habitat ad esso connessi.

Cultura, natura e turismo. - Come già affrontato nel paragrafo precedente, il progetto attuale si fa promotore da una parte della multifunzionalità e della diversificazione delle attività agricole, realizzando un collegamento tra habitat naturale presente e quello ripristinato in loco, mediante il coinvolgimento diretto della popolazione, delle associazioni e dei suoi attori locali, e dall'altra mediante la valorizzazione del territorio attraverso manifestazioni culinarie ed eventi culturali connessi direttamente con la locale tradizione salentina.

Andando a scavare nello specifico è necessario puntare la lente d'ingrandimento su entrambi gli aspetti, quello legato più alla salvaguardia della naturalità e quello che conduce direttamente alla promozione di eventi culturali, oltre che alla partecipazione diretta della popolazione, che rappresenta un grande aiuto per la comprensione delle tematiche ambientali e territoriali di questa zona

Il corpo attuale dell'opera prevede non solo l'installazione delle mezze lune all'interno del parco, ma anche una serie di strutture che siano di supporto all'obiettivo dei Tu'rat. Secondo la planimetria attuale, molte cose sono state realizzate (Parcheggio visitatori, gazebo per attività didattiche e ristoro e le dodici mezzelune) ma altre vanno ultimate (servizi igienici, completamento piantumazione della flora) e create (anfiteatro, parte di nuclei di macchina mediterranea e boscaglia di lecci attorno al Parco) per avere una complessiva struttura organica del Parco. 
La sistemazione a corte. - L'orto dei Tu'rat attualmente consta di ben dodici "condensatori" in pietra di Alessano di media e grande dimensione, ognuno dei quali costituisce una struttura che può essere definita "a corte"; ogni unità è delimitata da un muretto a secco (a forma di mezza luna) che la chiude parzialmente e la connette, attraverso la viabilità e i camminamenti, con le altre unità sparse sull'agro.

La motivazione alla base della sistemazione a corte è rintracciabile nell'uso razionale della risorsa acqua e nella lotta all'erosione superficiale.

Questi nuclei di vegetazione, dopo la loro piantumazione, si avvantaggeranno delle funzioni microclimatiche, idrauliche e biologiche tipiche dei muretti a secco. Questi ultimi svolgeranno processi di condensazione di umidità, grazie ai quali ogni singolo elemento vegetale usufruirà di un apporto aggiuntivo di acqua necessario e sufficiente allo sviluppo successivo delle stesse piante.

La tutela e la riproduzione della macchia mediterranea si incanala dentro argini ormai distrutti del contesto ambientale.

La funzione biologica ricoperta dalle corti, fa si che il verde presente in prossimità di esse, offra sia un rifugio ideale per una vegetazione spontanea (appunto mediterranea) ma anche un ottimo riparo per una serie di animali selvatici, utilissimi per un corretto mantenimento degli equilibri naturali. Le mezze lune fertili costituiscono pertanto il luogo in cui la flora incontra la fauna, dando l'opportunità ad entrambe di riprodursi in un contesto ideale ed equilibrato.

Le corti, costituite appunto dai Tu'rat, svolgono, come dimostrato anche da analoghi esempi sparsi nel Basso Salento, funzioni di filtraggio nel suolo delle acque meteoritiche. Il funzionamento idraulico del sistema suolo-muretto a secco, permette l'infiltrazione di acqua verso il terreno, alimentando la falda, riducendone il ruscellamento superficiale e il conseguente trasporto delle particelle di terra. Con l'ottimizzazione della 
regimazione idraulica, si ottiene una migliore conservazione del suolo, riducendo notevolmente l'evapotraspirazione, grazie alla captazione dell'acqua dei muretti.

Le corti, presenti lungo il tragitto del parco, prendono il nome dalla vegetazione che le caratterizza. Questa divisione è necessaria perché ogni vegetazione assume un ruolo a sé stante, in base alla propria necessità di acqua durante l'intero anno.

Il recupero della macchia mediterranea. - Lestenuante lavoro delle corti, del filtraggio di acqua grazie ai Tu'rat, non si esaurisce di certo qui. La macchia mediterranea, che ha sempre rappresentato un unicum all'interno dello scenario salentino, è anch'essa una caratteristica di recupero dei valori e salvaguardia del territorio. In questo caso entra a far parte del progetto dell'Orto dei Tu'rat l'obiettivo di sviluppare e diffondere una cultura del bosco di vegetazione originaria. In questo contesto, nella parte più estrema del parco è prevista la ricreazione di un piccolo lembo di quella che un tempo è stata la foresta sempreverde mediterranea. Questo obiettivo, ancora in fase iniziale, è perseguito con la ricostruzione ex-novo di un bosco naturalistico a predominanza di Leccio.

Questo intervento, oltre alle chiare valenze ambientali e naturalistiche, ha un profondo significato da parte della popolazione locale ed essere attrattore di un turismo naturalistico-ambientale, molto poco diffuso nel Basso Salento, per tutto l'anno solare.

Le diverse specie e associazioni floristiche che vogliono costituire il bosco sono facilmente fruibili grazie alla viabilità di servizio che ne delimita l'area. Obiettivo primario dell'intervento boschivo è quello di collegare il parco al contesto della terra da lavorare, mantenendo la sua fedeltà ad una cultura antica. Il cambio delle stagioni e il lavoro effettuato nei campi, porterà una nuova sensazione all'interno del parco, in cui sarà facile ammirare non solo i colori delle piante, ma anche come esso cambia con il territorio circostante e i seminativi dei campi coltivati. 
Cultura e spettacolo: il Cerchio degli Eventi. - Eventi e manifestazioni culturali legati alle tradizioni locali sono un giusto volano per un'educazione alla sostenibilità, amalgamandosi in una realtà che fa dell'ambiente il cardine della sua filosofia.

La presenza nel parco di installazioni perenni, ossia i Tu'rat, sono un'ottima coreografia e ambientazione per la realizzazione di performance di giovani artisti locali legati alla musica e allo spettacolo salentino, con il coinvolgimento fondamentale di enti pubblici, privati e associazioni culturali e di volontariato, in modo particolare nei periodi estivi.

L'Orto dei Tu'rat vuol essere un luogo aperto tutto l'anno, dove i colori delle stagioni e della campagna si possano amalgamare in partecipazione attiva della gente. In questo ambito il progetto prevede la realizzazione, soprattutto per i mesi meno caldi durante la stagione autunnale e primaverile, di una struttura perenne che possa accogliere questi eventi; in poche parole si tratta del cosiddetto "Cerchio degli Eventi", un anfiteatro semi coperto nella parte nord dell'Orto, in cui si potranno ammirare spettacoli musicali ed eventi letterari a stretto contatto con il cambio delle stagioni e con la natura del giardino.

Lo spirito di queste iniziative è quello di proporre un punto di vista differente verso la contemplazione e la comprensione di temi ambientali con vari adattamenti rispetto ai tradizionali contenitori teatrali o museali. Guardare sculture all'aperto, integrate in un contesto naturale, può essere un'esperienza sorprendente che può suscitare stupore e interesse nel visitatore, contestualizzate anche in base al tipo di evento proposto.

A partire dal 2012, la location dell'Orto ha visto la stesura di un calendario organico di eventi culturali e letterari, senza dimenticare quello della danza e musica salentina, che ha coinvolto anche appassionati e cultori del genere locale, con l'incremento del cachet già nel 2013, con la realizzazione della Rassegna "Mietiamo Nuvole" prevista dal 27 luglio al 7 agosto. 
Essendo l'Orto un luogo all'aperto, gli eventi si sono svolti soprattutto nel periodo estivo (in modo particolare tra luglio ed agosto) e nella metà di settembre, ma l'obiettivo è sicuramente realizzare in questo luogo strutture permanenti che possano accoglierli anche durante autunno inoltrato e primavera.

In quest'ottica gli eventi all'Orto vogliono essere attualmente una valida alternativa all'ormai atavica e ripetitiva usanza delle sagre e delle feste in piazza; se è vero che queste riescono a coinvolgere centinaia di persone, tra cui molti turisti desiderosi di "tradizioni locali", dall'altra parte condannano le usanze popolari, la musica salentina e la cucina tradizionale ad un ruolo che va ben oltre la loro essenza, relegandole ad essere soggette ad un intensivo sfruttamento di immagine, perdendone il vero senso culturale e storico.

In questo discorso, naturalmente, può essere inserita la realtà della Taranta con il suo concertone che si tiene, come tappa finale, al termine dell'estate a Melpignano. Da qualche anno questo evento itinerante, di grandissime proporzioni, è diventato un simbolo, a parere di chi scrive, troppo legato alla commercializzazione e ad una speculazione economica, che se da una parte produce introiti notevoli alle piazze e alle località, dall'altra diventa il simbolo di un Salento poco veritiero, distaccandosi definitivamente dalla sua vera origine di musica popolare, vero filo conduttore con le tradizioni locali. In questo campo il progetto dell'Orto non vuole sicuramente condannare quanto di buono è stato fatto dalle istituzioni locali e regionali in materia di promozione e valorizzazione di un prodotto, bensì cercare di tornare ad eventi più puri e tradizionali, come del resto era la Notte della Taranta alcuni anni orsono. Gli eventi e le manifestazione dell'Orto sono e vogliono essere rivolti ad un pubblico più attento alla materia, cercare di rivolgersi ad un mercato di nicchia, puntando soprattutto sul coinvolgimento attivo della popolazione e delle associazioni.

Quanto fatto finora, soprattutto nell'estate appena trascorsa, ha si contribuito a far conoscere la realtà di questa location verso 
un pubblico più attento, ma si è potuto constatare che fare musica, realizzare eventi culturali e letterari, magari gustando piatti tipici della tradizione salentina assieme ad un bicchiere di vino genuino, è possibile ed è la strada giusta per integrare sostenibilità ambientale, educazione all'ecologia e tradizioni popolari verso una cittadinanza attiva.

Ambiente e turismo culturale. - Come visto, gli obiettivi perseguiti dall'Associazione Culturale L'Orto dei Tu'rat rispecchiano un percorso che va al di là della semplice salvaguardia dell'ambiente e del ripristino del paesaggio mediterraneo. La riqualificazione del territorio deve essere sempre più connessa ad una sensibilizzazione delle persone, soprattutto con il coinvolgimento degli attori locali e in primis della popolazione residente.

Questi sono i veri catalizzatori di un progetto ben riuscito che può diventare più ampio, interfacciandosi anche con realtà diverse, mescolando tradizioni e costumi di gente proveniente anche dall'estero. Ė per questo motivo che la mission dell'Orto dei Tu'rat deve essere estesa anche al turismo culturale e ambientale, senza trascurare gli obiettivi principali, veri punti di riferimento di un percorso sempre più multi disciplinare.

In un sistema locale, il milieu locale (ossia tutte quelle risorse presenti sul territorio) è incentivato e prodotto dai soggetti/attori locali, i quali sono in grado di produrre queste risorse e "azionare" un meccanismo che va ben oltre la mera fruizione del territorio. Essi sono i veri produttori di rete locale, composta essenzialmente da rapporti stabili e di cooperazione tra soggetti.

Quello che si vuole mettere in evidenza e portare alla luce è un meccanismo che coinvolga la popolazione e l'Associazione Culturale "L'Orto dei Tu'rat", i cui soggetti vanno a collaborare insieme in un sistema locale, producendo competenze, idee e concertazione. Di contro L'Orto dei Túrat, rappresentato dai suoi soci presenti sul territorio, si avvale delle competenze degli attori locali per attivare 
azioni che siano in grado di far crescere e sviluppare l'idea di progetto che vada a toccare vari temi, interagendo a 360 gradi con le istituzioni, con la popolazione locale e in modo particolare con i turisti, veri fruitori esterni del territorio.

È questo contesto, ossia quello turistico, che questa realtà vuole fare nuovi passi, realizzando una rete di collaborazione con i soggetti locali, ma anche con Puglia Promozione, l'ente regionale della promozione turistica. L'idea fondamentale è ampliare il progetto verso uno scenario che porti economia e muova il turismo verso una direzione tutta nuova e di nicchia, senza naturalmente trascurare la vocazione balneare di queste zone.

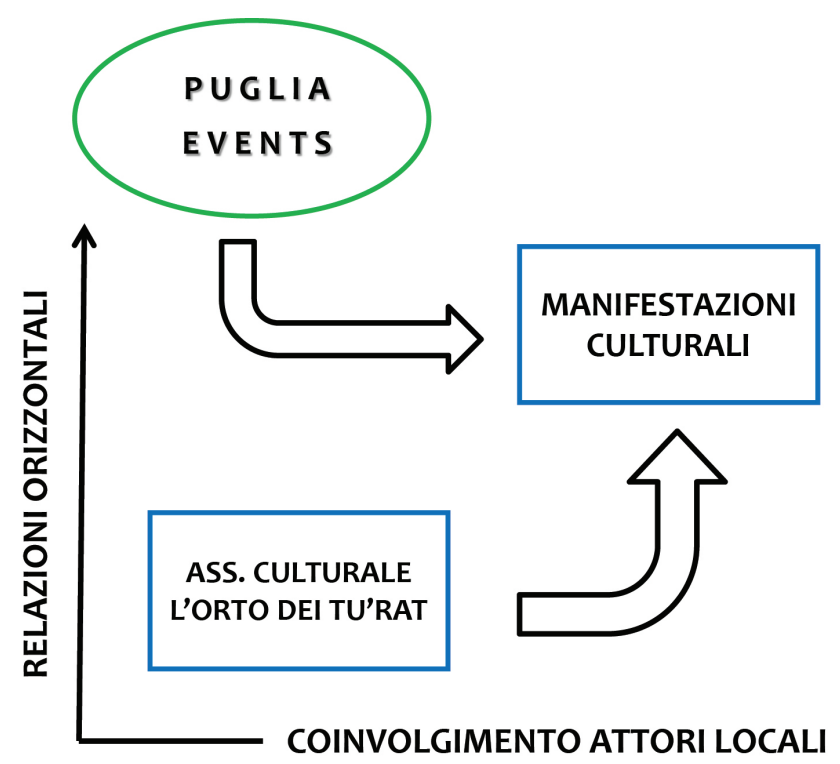

Fig. 1 - Coinvolgimento di attori locali per realizzazione di una rete di accoglienza sul modello francese delle Chambre d'hote. Fonte: elaborazione dell'Autore 
Come ben sappiamo il mare e il turismo balneare ormai sono risorse che possiedono tutti gli stati "concorrenti", ed essendo ormai un bene così sfruttato e scontato, è necessario affacciarsi a realtà come il turismo culturale, enogastronomico e in modo particolare quello ambientale e naturalistico.

Per fare questo, il progetto estende le sue visioni verso una concertazione di attori locali, che coinvolti nelle azioni dell'associazione concorrono a realizzare una rete di accoglienza turistica sul modello francese delle Chambre d'hote, ovvero le camere dell'ospite, molto diffuse in Provenza e Normandia. La normativa regionale vigente è la 17/2001, che fa riferimento ad una regolamentazione generale sulle strutture equiparate ai Bed\&Breakfast e affittacamere, e vorrebbe essere punto di riferimento per un discorso più ampio, in cui i soggetti locali diventano protagonisti e veri e propri operatori del settore.

Questo modello di struttura ricettiva vuol risultare di basso impatto ambientale e abbattere $\mathrm{i}$ costi di realizzazione e manutenzione delle strutture. Questo infatti si realizza utilizzando edifici in disuso appartenenti ad alcuni proprietari della zona, e riadattandoli, secondo la normativa vigente, con servizi primari e accessori, in cui il turista, prevalentemente straniero, possa interagire in maniera diretta con il proprietario di casa; questo fa si che si crei una partnership e un confronto tra ospite (proprietario di casa) e ospitante, in cui vi siano scambi culturali e linguistici, ma anche interazione sociale.

In tutto questo panorama intrecciato, l'Associazione Culturale L'Orto dei Tưrat avrà il ruolo di governance: dietro corrispettivo annuo da parte dei soci-proprietari di questi immobili, che saranno trasformati in strutture ricettive, l'Orto si occuperà di mettere in rete queste strutture, gestendo il portale di prenotazioni, promuovendo la rete di Chambre d'hote, ma soprattutto accogliendo i turisti presso il Parco, realizzando itinerari cicloturistici, con la collaborazione assidua di associazioni del settore, come Salento Bici Tour, vincitore 
del Bando Bollenti Spiriti del 2010 indetto dalla Regione Puglia. Tutto ciò deve essere improntato alla scoperta della natura, delle tradizioni ma anche delle realtà storico-artistiche del Basso Salento, ed infine partecipare attivamente a rassegne ed eventi presso le strutture del Parco.

L'offerta del Parco naturalmente non si esaurisce solamente in questa direzione. L'idea primaria è quella di affrontare i temi dell'ambiente e della socialità a 360 gradi, con la realizzazione di un calendario eventi che possa riallacciarsi alla tradizione salentina, ormai snaturata da tempo da manifestazioni "globalizzate".

Manifestazioni ad impatto culturale: PugliaEvents. - In questo senso sarà necessario il coinvolgimento di realtà sovralocali, come PugliaEvents, un progetto a titolarità regionale per la creazione di un "Cartellone Regionale di Eventi" della Puglia, attuato dal Consorzio Teatro Pubblico Pugliese nell'ambito del Programma Operativo F.E.S.R. 2007-2013 Asse IV. Questo progetto comunica e promuove, attraverso azioni di comunicazione integrata, in Puglia ma anche in Italia e all'Estero, le eccellenze delle produzioni culturali dello spettacolo pugliese, dei Festival, delle mostre e degli eventi locali. Queste azioni sono volte a far conoscere al grande pubblico regionale, nazionale e internazionale la ricchezza delle risorse culturali pugliesi nonché delle sue eccellenze turistiche.

La complessità e varietà delle produzioni culturali e di spettacolo che per loro natura sono strumenti di valorizzazione e promozione del patrimonio culturale del territorio, sono supportate da una variegata e capillare attività di comunicazione ed informazione che ha come intento quello di raggiungere il grande pubblico e favorire l'attrazione di flussi turistici.

Le attività di comunicazione ed informazione previste dal piano di comunicazione integrato fungono da moltiplicatori di visibilità e conoscenza del territorio in Italia e all'estero. 
Non ultimo, le attività di comunicazione hanno l'obiettivo di sistematizzare la diffusione della comunicazione delle eccellenze delle produzioni culturali e di spettacolo nel territorio pugliese.

In questo contesto si può inserire l'attività dell'Associazione "L'Orto dei Tu'rat", mediante un'interazione più approfondita con PugliaEvents, che possa permettere un dialogo con i potenziali visitatori e gli operatori culturali e turistici; questo sarà necessario principalmente per consentire ai turisti di accedere in maniera immediata alle molteplici proposte culturali, e di conseguenza avere la possibilità di pianificare la propria presenza sul territorio.

Per avere occasione di farsi conoscere anche all'esterno, l'Associazione Culturale "L'Orto dei Tu'rat", mediante il coinvolgimento degli attori locali e collaborazioni con Associazioni culturali, editori e realtà musicali emergenti e consolidate, si iscriverà al Database Regionale degli Eventi sul portale pugliaevents. it, in qualità di organizzazione privata no profit, con la possibilità quindi di promuovere direttamente i propri eventi con un'ampia diffusione regionale e nazionale. Inoltre grazie a questa possibilità di registrazione, i fruitori degli eventi, turisti e non, potranno iscriversi al portale in qualità di persone fisiche, segnalando gli eventi rilevanti e partecipando attivamente ai live blogging e ai social network.

Piano della comunicazione. - La comunicazione è quello strumento che permette di trasmettere informazioni tra persone, tra associazioni, tra istituzioni, e tra esse e il cittadino.

Fino ad oggi l'Associazione Culturale "L'Orto dei Tu'rat" ha utilizzato vari canali di comunicazione per farsi conoscere e approfondire le tematiche alla base del progetto. Sono stati realizzati forum e focus group con l'intento di spiegare le dinamiche all'interno di scuole e associazioni ed illustrare il valore delle me- 
zze lune per il suolo, il complesso dell'ecosistema che si sta costruendo nel parco e gli intenti a breve scadenza.

Sicuramente è giusto percorrere questa strada come primo passo, ma è necessario fare di più, approntando un piano della comunicazione più efficace e che si radichi all'interno di un panorama più vasto.

Attualmente viviamo in un mondo in cui le tecnologie internet, del web e dei social media fanno da padroni, realizzando reti e scambio di informazioni senza precedenti. Un ottimo piano della comunicazione potrà essere l'intensificazione delle risorse basate sui social media e su internet, utilizzando le piattaforme Facebook, Twitter e Youtube per quanto riguarda le prime, ma anche arricchire l'offerta presente sul sito ufficiale dell'Associazione (oggi ben strutturato e ricco di contenuti) con forum tematici, e-shop e notizie sempre aggiornate.

La partecipazione attiva degli internauti e di tutti coloro che utilizzano internet anche solo per navigare, controllare la posta elettronica e fare ricerche è un ottimo volano per farsi conoscere anche al di fuori di una realtà che va a volte troppo stretta.

Come già accennato, anche l'inserimento sul portale Puglia Events, all'interno di un Database di Eventi Regionale, potrà essere una vera spinta per farsi conoscere a $360^{\circ}$.

L'impegno futuro dell'Associazione Culturale non si fermerà qui e affronterà le tematiche dell'ambiente anche nelle scuole primarie e secondarie, ma soprattutto in quelle superiori, officine della futura generazione in cui insegnare l'educazione all'ambiente e alla sostenibilità. Comunicare i valori della naturalità e della salvaguardia del territorio attraverso un piano organico, che preveda incontri, meeting, focus group e lezioni frontali di un'ora, può essere un ottimo volano per far apprendere ai ragazzi che un mondo nuovo è possibile e va difeso. L'idea è quella di coinvolgere, in modo particolare nel periodo scolastico, i presidi delle scuole dei paesi limitrofi e stilare programmi e manifestazioni, anche con il 
supporto di soggetti pubblici locali, delle Associazioni di categoria, ma anche con l'aiuto di Legambiente e Coldiretti.

Lavorare in sinergia con gli enti pubblici e privati, ma anche in una rete di operatori culturali, sarà l'intento dei soci dell'Associazione "L'Orto dei Tu'rat", i quali hanno già gettato le basi per cooperazioni nel panorama del Basso Salento. Realizzare un calendario di eventi e educazione ambientale sono operazioni non solo di carattere sociale ma anche di marketing; farsi conoscere all'esterno e trasmettere i valori e la mission del Parco saranno sicuramente una delle sfide che si dovranno affrontare a medio e lungo termine nei prossimi anni, avendo il coraggio di fare valutazioni e scelte, senza perdere di vista l'obiettivo della sostenibilità ambientale.

Considerazioni finali. - Rimanendo legati ai principi di sostenibilità e naturalità, la proposta di progetto quindi si affaccia anche ad un'idea di destagionalizzazione del turismo, cercando di dare respiro ad un territorio intensamente sfruttato durante la stagione estiva.

Questo non vuol essere solo un incentivo a migliorare ciò che già è presente all'interno del parco, ma il tentativo di convogliare le forze e gli intenti di tutti verso azioni che vanno ben oltre la mera salvaguardia del territorio, che rimane il punto focale dell'Associazione Culturale. Cercare di dare un'impronta più imprenditoriale, coinvolgendo gli attori locali e i soggetti privati, è il fine di questa proposta che vuole inserirsi in un discorso più ampio che interessi anche il settore turistico, nel tentativo di innovarlo e renderlo più alternativo.

La diffusione della naturalità, la riqualificazione del paesaggio integrata con la fruizione del territorio mediante la creazione di una rete di accoglienza e la calendarizzazione di eventi e manifestazioni ad impatto culturale, potranno essere fondamentali per la crescita del parco, ma anche per far comprendere ed educare la gente verso 
i temi sensibili dell'ambiente e della salvaguardia del territorio, vero ponte tra passato e futuro per le prossime generazioni.

Attraverso una concreta concertazione tra enti ed associazioni, ma anche con un coinvolgimento diretto della popolazione, attori locali e soggetti sovralocali, sarà possibile realizzare questa oasi nel deserto salentino.

\section{Bibliografia}

M. Bagliani, F. Ferlaino, Sistemi locali territoriali e sostenibilità ambientale, Torino, IRES Piemonte, 2003.

M. Bertoncin, A. Pase, Territorialità. Necessità di regole condivise e nuovi vissuti territoriali, Milano, Angeli, 2006.

C. Bonanno, L. Briseghella, A. Buggin, Economia e gestione dell'ambiente, Padova, CLEUP, 2005.

S. Borghesi, A. Vercelli, La sostenibilità dello sviluppo globale, Roma, Carocci, 2005.

A. Caru, B. Cova, Marketing mediterraneo, Milano, Egea, 2006.

G. Cesaretti, R. Misso, Z. Andreaopoulou, Sostenibilità dello sviluppo e dimensione territoriale. Il ruolo dei sistemi regionali a vocazione rurale, Milano, Angeli, 2012.

F. Ceschin, B. Susio, S. Montanari, Territori strategici, modelli di pianificazione per lo sviluppo dei sistemi locali, Milano, Angeli, 2007.

A. Cicerchia, Risorse culturali e turismo sostenibile, Milano, Angeli, 2009.

S. Conti, Geografia economica. Teorie e metodi, Torino, UTET, 1996.

P. Corsi, Ai confini dell'Impero, Bisanzio e la Puglia dal VI all'XI secolo, Bari, Biblios, 2002.

N. Costa, La città ospitale, Milano, Mondadori, 2008.

P. Dalla Sega, C. Vivalda, Gli eventi culturali: ideazione, progettazione, marketing, comunicazione, Milano, Angeli, 2005.

E. Dansero, Eco-sistemi locali, Milano, Angeli, 1996.

G. Dematteis, F. Governa, Territorialità, sviluppo locale, sostenibilità: il modello slot, Milano, Angeli, 2009.

G. Dematteis, F. Governa, Contesti locali e grandi infrastrutture. Politiche e progetti in Italia per lo sviluppo locale, Milano, Angeli, 2001.

S. De Renzi, Osservazioni sul tarantismo di Puglia, Lecce, Kurumuny, 2012. 
C. Emanuel, P. Vallaro, Prove di sostenibilità, progetti, piani e valutazione per un processo di sviluppo urbano sostenibile a Novara, Novara, Università del Piemonte Orientale "Amedeo Avogadro" - Comune di Novara, 2005.

C. Emanuel, R. Afferni, Piano d'azione per lo sviluppo della promozione, dell'accoglienza e dell'informazione turistica nella provincia di Novara, Vercelli, Edizioni Mercurio, 2009.

M. Faccioli, Processi territoriali e nuove filiere urbane, Milano, Angeli, 2009.

A. Garzoni, Imprenditorialità, risorse e sviluppo del territorio, Milano, Egea, 2006.

K. Godfrey, J. Clarke, Manuale di marketing territoriale per il turismo, Firenze, Le Monnier, 2002.

F. Governa, Il milieu urbano: l'identità territoriale nei processi di sviluppo, Milano, Angeli, 1997.

M. Kozak, Destination Benchmarking, "Annals Tourism Research", 2002, 2, pp. 497-519,.

P. Kotler, J. Bowen, J. Makens, Marketing del turismo, Milano, Pearson Prentice Hall, 2010.

Ipres, Puglia in Cifre 2009-2010, Bari, Cacucci, 2010, 2011.

A. Lanzani, A piedi, immaginando un paesaggio per la geografia e l'urbanistica, in Le frontiere della geografia, Torino, UTET, 2009 pp. 245-274.

A. Montanari, Grandi eventi, marketing urbano e realizzazione di nuovi spazi turistici, "Bollettino della Società Geografica Italiana", 2002, pp. 757-781.

F. Renzo, Slow foot. Per uno sviluppo locale sostenibile del Basso Salento, Lecce, Libellula, 2012.

G. Scanderebech, La civiltà della pietra: archeologia ed architetture in pietra nel basso salento, Lecce, Levante Arti Grafiche, 2004.

A. Segre, E. Dansero, Politiche per l'ambiente, Torino, UTET Libreria, 1996.

L. Senn, M. Percoco, Trasporti e sostenibilità ambientale, Milano, Egea, 2003.

A. Tanese, La pianificazione per lo sviluppo del territorio - Analisi e strumenti per l'innovazione, Roma, Rubbettino, 2006.

M. Tinacci Mossello, La sostenibilità dello sviluppo locale, Bologna, Pàtron, 2001.

M. Tinacci Mossello, Politica dell'ambiente, Bologna, Il Mulino, 2008.

G. Troilo, Il marketing dell'arte. Postmodernità, consumo e marketing dei beni artistici e culturale, "Micro \& Macro Marketing", 1, 2002.

C. Zoppi, Valutazione e pianificazione delle trasformazioni territoriali nei processi di governance ed e-governance, Milano, Angeli, 2012. 


\section{Sobre os autores}

\section{Amanda Danelli Costa}

Historiadora, mestre e doutora em História pela PUC-Rio, é professora adjunta do Departamento de Turismo do IGEOG/ UERJ. Desenvolve pesquisas e projetos de extensão nas áreas de história do Rio de Janeiro, cultura contemporânea e turismo cultural.

\section{Clara Carvalho de Lemos}

Bacharel em Turismo, mestre e doutora em Engenharia Ambiental pela UFSCAR, é professora adjunta do Departamento de Turismo do IGEOG/UERJ. Desenvolve pesquisas e projetos de extensão nas áreas de planejamento turístico, gestão de destinos e gestão ambiental do turismo.

\section{Christovam Barcellos}

Geógrafo, mestre em Ciências Biológicas pela UFRJ, doutor em Geociências pela UFF e pós-doutor em Ciências da Saúde pelo IRD/França, é pesquisador titular da FIOCRUZ, desenvolvendo pesquisas e projetos na área de saúde pública e meio ambiente. 


\section{Marcelo Antonio Sotratti}

Engenheiro agrônomo, mestre e doutor em Geografia pela UNICAMP, é professor adjunto do Departamento de Turismo do IGEOG/UERJ. Desenvolve pesquisas e projetos de extensão nas áreas de planejamento e políticas públicas de turismo, turismo cultural e patrimônio.

\section{Rafael Ângelo Fortunato}

Bacharel em Turismo, mestre em Desenvolvimento Regional e Meio Ambiente pela UNIARA e doutor em Meio Ambiente pela UERJ, é professor adjunto do Departamento de Turismo do IGEOG/UERJ. Desenvolve pesquisas e projetos de extensão nas áreas de turismo solidário, ecoturismo e gestão ambiental do turismo.

\section{Vanina Heidy Matos Silva}

Bacharel em Turismo, mestre em Hospitalidade pela Universidade Anhembi Morumbi e doutora em Saúde Pública e Meio Ambiente pela FIOCRUZ, é professora adjunta do Departamento de Turismo do IGEOG/UERJ. Desenvolve pesquisas e projetos de extensão nas áreas de saúde do viajante e hospitalidade.

\section{Alessandro Macchia}

Laureato in Progettazione e Gestione dei Sistemi Turistici nell'Università degli Studi di Roma Tor Vergata. Attualmente ricopre i ruoli di Event coordinator e Social Media Manager presso Green Holidays Tour Operator - Tournelsud.com in Bari - Puglia (Italia).

\section{Anna Tanzarella}

Dottore di ricerca in Geografia, laureata in Progettazione e Gestione dei Sistemi Turistici. I suoi interessi scientifici sono rivolti alle dinamiche dello sviluppo e della pianificazione turistica in ambito rurale e urbano, e all'analisi di fonti geo-storiche e 
cartografiche per la valorizzazione del patrimonio territoriale. Ha partecipato a numerosi progetti di ricerca relativi a queste tematiche.

\section{Francesca Spagnuolo}

Dottore di ricerca in Geografia Economica, laureata in Progettazione e Gestione dei Sistemi Turistici. Docente e consulente, è esperta in pianificazione turistica e sviluppo locale. È manager di rete, fornisce assistenza alle piccole e medie imprese e agli enti locali per lo sviluppo turistico e la costruzione di reti e aggregazioni tra gli operatori del settore.

\section{Marina Faccioli}

Professore ordinario di Geografia Economico-Politica, docente di Geografia per la pianificazione del turismo nell'Università di Roma Tor Vergata. Studia i percorsi organizzativi dei sistemi territoriali complessi, con particolare attenzione alle recenti dinamiche di affermazione del processo turistico.

\section{Paola Nicoletta Imbesi}

Architetto, è dottore di ricerca in Urbanistica Tecnica presso il Politecnico di Milano. Cultrice della materia in Urbanistica, svolge attività didattica e di ricerca presso la Facoltà di Ingegneria dell'Università Politecnica delle Marche e presso la Facoltà di Architettura dell'Università Sapienza di Roma. 


\section{ed \\ $\mathbf{u}$ e $\mathbf{r}$}

Formato 14 x 21

Tipologia: Garamond (texto) Avalon (títulos)

Papel: Offset $90 \mathrm{~g} / \mathrm{m}^{2}$ (miolo)

Supremo $250 \mathrm{~g} / \mathrm{m}^{2}$ (capa)

CTP, impressão e acabamento: Editora Vozes 